UNIVERSIDADE DE SÃO PAULO

FACULDADE DE EDUCAÇÃO

LEONARDO ANDRÉ TESTONI

CAMINHOS CRIATIVOS E ELABORAÇÃO DE CONHECIMENTOS PEDAGÓGICOS DE CONTEÚDO NA FORMAÇÃO INICIAL DO PROFESSOR DE FÍSICA

SÃO PAULO

2013 
LEONARDO ANDRÉ TESTONI

\section{CAMINHOS CRIATIVOS E ELABORAÇÃO DE CONHECIMENTOS PEDAGÓGICOS DE CONTEÚDO NA FORMAÇÃO INICIAL DO PROFESSOR DE FÍSICA}

Tese entregue à Faculdade de Educação da Universidade de São Paulo como requisito parcial para a obtenção do título de Doutor em Educação.

Área de concentração: Ensino de Ciências e Matemática

Orientação: Prof ${ }^{\mathrm{a}}$. Dra. Maria Lúcia Vital dos Santos Abib

(versão revisada)

\section{SÃO PAULO}

2013 
AUTORIZO A REPRODUÇÃO E DIVULGAÇÃO TOTAL OU PARCIAL DESTE TRABALHO, POR QUALQUER MEIO CONVENCIONAL OU ELETRÔNICO, PARA FINS DE ESTUDO E PESQUISA, DESDE QUE CITADA A FONTE.

\section{Catalogação na Publicação}

Serviço de Biblioteca e Documentação

Faculdade de Educação da Universidade de São Paulo

371.12 Testoni, Leonardo André

T345c Caminhos criativos e elaboração de conhecimentos pedagógicos de conteúdo na formação inicial do professor de física / Leonardo André Testoni; orientação Maria Lúcia Vital dos Santos Abib. São Paulo: s.n., 2013.

293 p. ils.; tabs.; anexos

Tese (Doutorado - Programa de Pós-Graduação em Educação. Área de Concentração: Ensino de Ciências e Matemática) - - Faculdade de Educação da Universidade de São Paulo.

1. Criatividade 2. Estágios supervisionados 3. Cognição 4. Psicologia cognitiva 5. Formação de professores 6. Piaget, Jean, 1896-1980 I. Abib, Maria Lúcia Vital dos Santos, orient. 
FOLHA DE APROVAÇÃ̃

TESTONI, L.A., Caminhos Criativos e Elaboração de Conhecimentos Pedagógicos de Conteúdo na Formação Inicial do Professor de Física. Tese apresentada à Faculdade de Educação da Universidade de São Paulo como requisito para obtenção do título de Doutor em Educação (Área de Concentração: Ensino de Ciências e Matemática).

Aprovado em:

\section{Banca Examinadora}

Prof. Dr. Institutição:

Julgamento: Assinatura:

Prof. Dr. Institutição:

Julgamento: Assinatura:

Prof. Dr. Institutição:

Julgamento: Assinatura:

Prof. Dr. Institutição:

Julgamento: Assinatura:

Prof. Dr. Institutição:

Julgamento: Assinatura: 
DEDICATÓRIA

\footnotetext{
À minha mãe (in memorian), minha primeira educadora e de quem herdei a paixão pelo magistério.
} 


\section{AGRADECIMENTOS}

A Deus, pela concessão de força, sabedoria e perseverança, que sempre me permitiram prosseguir com minha paixão pela educação.

À Maria Lucia, orientadora deste trabalho, pelas críticas, sugestões e encaminhamentos que buscaram desenvolver, não apenas esta pesquisa, mas minha própria formação e evolução, enquanto pesquisador.

Novamente à Maria Lucia, agora amiga de mais de uma década, que através de sua compreensão e bondade, esteve comigo nos momentos mais felizes, mas, também, sempre presente ao meu lado nas situações mais difíceis, aconselhando-me e fortalecendo minha caminhada.

Ao meu pai Leonardo e tia Selma, que sempre me ensinaram que os verdadeiros sonhos existem para serem alcançados, exigindo de nós dedicação e disciplina proporcionais à sua magnitude.

À minha esposa Andréia, por todo amor e apoio, mas principalmente, paciência que despendeu nestes últimos anos, para que fosse possível a realização deste trabalho.

Ao Enzo, que, nesse momento, conseguirá ler algumas poucas palavras desta pesquisa, mas que, com toda sua alegria e peraltices, revitalizava-me diariamente para que pudesse continuar perseguindo inovações na educação.

Aos amigos Thaís, Sílvia, Micheline, Pedro, Paulo, Edson, Simone, Edu e Ricardo, que sempre me incentivaram na realização desse trabalho.

Aos amigos do Grupo de Formação de Professores da FEUSP, que sempre colaboraram com críticas e sugestões que enriqueceram essa pesquisa.

Ao amigo Alex, pelas infindáveis discussões e aprofundamentos sobre os Conhecimentos Pedagógicos de Conteúdo e a Formação Docente.

Aos professores João Zanetic e Yassuko Hosoume, que, há 15 anos, iniciaramme na pesquisa acadêmica, com ensinamentos que se incorporaram em meu repertório docente e, hoje, cristalizam-se na confecção desse trabalho. 
“A criatividade é o poder de conectar o, aparentemente, desconectado".

(Willian Plomer) 


\section{RESUMO}

Nas últimas décadas, o desenvolvimento da criatividade vem sendo debatido e tratado como característica fundamental aos indivíduos que se encontram no mercado de trabalho. No caso da carreira docente, tal fato não se mostra diferente, sendo recorrentes os pedidos de professores com uma ampla capacidade de criar novas e inovadoras intervenções didáticas frente ao caráter imprevisível do cotidiano escolar. Desse modo, o presente trabalho busca compreender como se dá o processo de criação de novos conhecimentos pedagógicos de conteúdo por parte de futuros professores de Física, elencando elementos importantes necessários a essa ação, bem como às interrelações entre os mesmos.

Para tanto, em um primeiro momento, alicerçamos nossa pesquisa no campo da formação de professores, mais precisamente, a forma como estes elaboram seus Conhecimentos Pedagógicos de Conteúdo. Em uma segunda etapa, tratamos o ato criativo como uma complexa rede de elementos pertencentes, tanto aos esquemas cognitivos internos do futuro docente, como específicos do meio social e cultural onde a docência se realiza. Dessa forma, para abarcar esse dois contextos mais amplos da criação humana, utilizamos elementos das psicologias piagetiana e vigotskiana, respectivamente. Esses últimos referenciais teóricos, em nossa visão, organizados como complementares na elaboração de um novo referencial para o estudo específico da criatividade docente.

A pesquisa de campo, de natureza qualitativa, acompanhou dois grupos de licenciandos em Física que cursavam a disciplina "Metodologia do Ensino de Física II" e que realizavam o processo de estágio em escolas da educação básica em um caráter supervisionado e investigativo. Dessa forma, os dados utilizados nesse trabalho foram obtidos através dos relatos dos próprios licenciandos, quando de sua participação nas reuniões semanais de supervisão, nas entrevistas finais, durante as aulas da disciplina, bem como nos registros contidos em seus portfólios.

Os resultados obtidos nos demonstraram que os licenciandos, em situações de docência, são submetidos a perturbações de diferentes naturezas, de acordo com o contexto onde estes se encontravam. A superação de tais perturbações mostrou-se extremamente dependente dos elementos culturais e sociais a que estavam expostos os futuros docentes, bem como dependentes de seus repertórios anteriores e experiências vividas. Os possíveis trajetos realizados pelos estagiários nesses contextos foram denominados Caminhos Criativos, trajetos estes compostos pela perturbação geradora, a conduta adotada pelos futuros professores para sua solução, bem como as necessidades docentes surgidas no percurso, culminando com a elaboração de novos Conhecimentos Pedagógicos de Conteúdo, onde se verificou alterações na forma como tais estagiários relacionavam as dimensões do contexto, pedagógicas e do conteúdo em suas novas intervenções didáticas.

O trabalho em tela, portanto, busca expor um conjunto de processos necessários às elaborações criativas dos futuros professores e suas interrelações na dinâmica do desenvolvimento de novos Conhecimentos Pedagógicos de Conteúdo, buscando dessa forma, contribuir com novos elementos que busquem, na formação docente em Física, um profissional capaz de atuar em patamares crítico-reflexivos, com capacidade e autonomia de elaborações e reelaborações de seus esquemas mentais, frente aos constantes imprevistos que permeiam o ambiente profissional do magistério.

Palavras - Chave: Formação Inicial de Professores, Estágio, Processos Criativos, Conhecimentos Pedagógicos de Conteúdo. 


\begin{abstract}
In recent decades, the development of creativity has been discussed and treated as a fundamental characteristic to individuals who are in the labor market. In the case of the teaching as a profession, this fact does not seem different, being recurrent the requests of teachers with a broad ability to create new and innovative didactic interventions due to the unpredictable character of the school routine. Thus, this study seeks to understand how the process of creation of new pedagogical content knowledge by future physics teachers, listing important elements necessary for this action, as well as the interrelationships among them.

Therefore, at first, we build our research in the field of teacher training, more precisely, how they prepare their Pedagogical Content Knowledge. In a second step, we treat the creative act as a complex network of elements belonging to both internal cognitive schemata of future teachers as specific social and cultural environment in which teaching takes place. Thus, to encompass these two broader contexts of human creation, use elements of the psychologies of Piaget and Vygotsky, respectively. These recent theoretical, in our view, arranged as complementary in the development of a new framework for the study of specific teaching creativity.

The field research was qualitative, followed two groups of undergraduates in physics who attended the course "Methodology of Teaching Physics II" and who took the internship process in basic education schools in a supervised and investigative character. Thus, the data used in this work were obtained from the reports of their own undergraduates, when he participated in weekly supervision meetings, the final interviews during the lessons of discipline, as well as the records contained in their portfolios.
\end{abstract}

The obtained results showed that the licensees in situations teaching are subjected to disturbances of different natures, according to the context in which they are found. Overcoming such disturbances was extremely dependent on the cultural and social elements that were exposed to future teachers as well as dependents of their repertoires and previous experiences. The possible paths made by the trainees in these contexts were called Creative Paths, paths these compounds by the disturbance generator, the procedure adopted by future teachers for their solution, as well as the needs arising in the course teachers, culminating in the development of new Pedagogical Content Knowledge, where there has been changes in the way such trainees related dimensions of context, pedagogical and content in their new didactic interventions

The screen work therefore seeks to expose a set of process needed for creative elaboration of future teachers and their interrelationships in the dynamics of development of new Pedagogical Content Knowledge, seeking, thereby, to contribute with new elements that seek, in teacher training in Physics, a professional capable of operating at levels critical- reflective capacity and autonomy of elaborations and reworkings of their mental schemas, facing the constant unforeseen that permeate the working environment of teachers. Key - Words: Initial Teacher Training, Internship , Creative Processes , Pedagogical Content Knowledge . 


\section{RESUMEN}

En las últimas décadas, el desarrollo de la creatividad ha sido discutido y tratado como una característica fundamental de los individuos que están en el mercado laboral. En el caso de la profesión docente, este hecho no parece diferente, siendo las peticiones recurrentes de los profesores con una amplia capacidad de crear nuevas e innovadoras intervenciones didácticas contra el carácter impredecible de la rutina escolar. Por lo tanto, este estudio busca entender cómo el proceso de creación de nuevo conocimiento didáctico del contenido de los futuros profesores de física, enumerando los elementos importantes necesarios para esta acción, así como las interrelaciones entre ellos.

Por lo tanto, en un primer momento, construimos nuestra investigación en el campo de la formación docente, más precisamente, cómo preparan su conocimiento del contenido pedagógico. En un segundo paso, tratamos el acto creativo como una compleja red de elementos que pertenecen a ambos esquemas cognitivos internos de los futuros docentes como el medio ambiente social y cultural en el que tiene lugar la enseñanza. Por lo tanto, para abarcar estos dos contextos más amplios de la creación humana, utiliza elementos de la psicología de Piaget y Vygotsky, respectivamente. Estos últimos teóricos, a nuestro juicio, dispuestos como un complemento en el desarrollo de un nuevo marco para el estudio de la creatividad enseñanza

específica.

La investigación de campo fue cualitativa, seguido a dos grupos de estudiantes de la física que asistieron al curso "Metodología de la Enseñanza de la Física II " y que tomó el proceso de prácticas en las escuelas de educación básica en un personaje supervisado y de investigación. Por lo tanto, los datos utilizados en este trabajo se obtuvieron de los informes de sus propios estudiantes, cuando participó en las reuniones semanales de supervisión, las entrevistas finales durante las lecciones de disciplina, así como los registros que figuran en suscarteras.

Los resultados obtenidos mostraron que los licenciatarios en situaciones de enseñanza están sometidos a perturbaciones de diferentes naturalezas, según el contexto en el que se encuentran. La superación de estas alteraciones fue muy dependiente de los elementos culturales y sociales que fueron expuestos a los futuros docentes, así como los dependientes de sus repertorios y experiencias anteriores. Los posibles caminos hechos por los alumnos en estos contextos se llaman caminos creativos, senderos estos compuestos por el generador de perturbaciones, el procedimiento adoptado por los futuros docentes para su solución, así como las necesidades que surgen en los profesores del curso, que culminó en el desarrollo de nuevos conocimientos de contenido pedagógico, donde ha habido cambios en la forma en que estos alumnos relacionan las dimensiones del contexto pedagógico y el contenido en sus nuevas intervenciones didácticas.

Por tanto, el trabajo de la pantalla pretende exponer un conjunto de procesos necesarias para la elaboración creativa de los futuros docentes y sus interrelaciones en la dinámica del desarrollo de nuevos conocimientos de contenido pedagógico, buscando con ello aportar nuevos elementos que buscan, en la formación del profesorado de Física , un profesional capaz de funcionar a niveles de capacidad crítica -reflexiva y la autonomía de las elaboraciones y reelaboraciones de sus esquemas mentales, frente a imprevistos que surgen el ambiente de trabajo de los docentes. Palabras - Clave: Formación inicial del profesorado, prácticas, procesos creativos, Conocimiento de contenido pedagógico. 


\section{LISTA DE FIGURAS}

Figura 1 - HQ utilizada (Testoni, 2004).

Figura 2 - Hierarquia no Modelo Técnico.

Figura 3 - Modelo do Raciocínio Pedagógico na elaboração do PCK, adap. Moraes (2009, p.71).

Figura 4 - Níveis individual, comunitário e político do desenvolvimento docente. (Extraído de Shulman \& Shulman (2004)).

Figura 5 - Modelos Integrativo e Transformativo propostos por Gess-Newsome (1999).

Figura 6 - Rede contextual envolvida na elaboração do PCK (extraído de Abell (2007)).

Figura 7 - Representação gráfica do desenvolvimento do intelecto e do imaginário (extraído de Vigotsky (2009)).

Figura 8 - Modelo de episódio de interesse acadêmico.

Figura 9 - Os níveis criativos vigotskianos adaptados para o modelo de Caminhos Criativos.

Figura 10 - Esquema do Caminho Criativo Lacunar do Grupo I.

Figura 11 - Esquema do Caminho Criativo Beta do Grupo I.

Figura 12 - Esquema de Caminho Criativo Gama do Grupo I.

Figura 13 - Esquema de Caminho Criativo Gama do Grupo I.

Figura 14 - Esquema de Caminho Criativo Gama do Grupo I.

Figura 15 - Exemplos das cartas utilizadas no jogo (nos quadros à esquerda dos astros, encontram-se os respectivos valores de suas características físicas)

Figura 16 - Esquema do Caminho Criativo Alfa do Grupo II.

Figura 17 - Esquema do Caminho Criativo Alfa do Grupo II.

Figura 18 - Esquema de Caminho Criativo Gama do Grupo II.

Figura 19 - Esquema de Caminho Criativo Gama do Grupo II.

Figura 20 - Esquema Geral do Ciclo Criativo Docente.

Figura 21 - Esquema da aprendizagem da docência relativo à criatividade docente. 


\section{LISTA DE TABELAS}

Tabela 1 - extraída de Mendes (2005, p.2).

Tabela 2 - Modelo Tipológico para identificar e classificar os saberes dos professores adap. de Tardif \& Reymond (2000).

Tabela 3 - Modelos Integrativo e Transformativo do PCK (traduzido a partir de GessNewsome (1999, p.14)).

Tabela 4 - -síntese relacionando as perguntas da entrevista final e os elementos teóricos que procuraram ser observados a partir delas.

Tabela 5 - Quadro-resumo dos instrumentos utilizados na pesquisa.

Tabela 6 - Processo Criativo do Grupo I.

Tabela 7 - Processo Criativo do Grupo II. 


\section{LISTA DE QUADROS}

Quadro 1 - Síntese da caracterização do Grupo de Estágio I.

Quadro 2 - Síntese da caracterização do Grupo de Estágio II.

\section{LISTA DE ESQUEMAS}

Esquema 1 - Modelo de PCK utilizado (adaptado de Grossman (1990)).

Esquema 2 - Visão de PCK Integrativo adotado nesse trabalho. 


\section{SUMÁRIO}

\section{CAPÍTULO I - ORIGENS DA TESE E SUA ESTRUTURAÇÃO, 17}

1. Origens e Problema de Pesquisa, 18

2. Criação, Criatividade, Inovação e Escola, 24

3. Estrutura do Trabalho, 28

\section{CAPÍTULO II - ASPECTOS FORMATIVOS DO PROFESSOR DE FÍSICA, 31}

1. Aspectos Gerais do Ensino de Ciências, 32

2. Aspectos Formativos do Professor de Ciências: um breve contexto, 35

3. Os Modelos Formativos Profissionais, 38

3.1. O Técnico, 38

3.2. O Professor Reflexivo, 40

3.3. O Intelectual Crítico, 46

4. Formação Inicial e Processo de Estágio: demandas atuais, 45

5. A fase pré-docência, 52

6. O Conhecimento Pedagógico de Conteúdo: conceituações e breve histórico, 54

7. O Ato Criativo Inovador e o Conhecimento Pedagógico de Conteúdo, 73

\section{CAPÍTULO III - O ATO CRIATIVO, 77}

1. O Ato Criativo na Psicologia Piagetiana, 78

2. O Ato Criativo na Psicologia Vigotskiana, 89

2.1. Consciência e Atividade, 89

2.2. Vigotsky e a Criação, 94

3. O Ato Criativo Inovador como Atividade Docente, 99

4. Piaget e Vigotsky: divergências e aproximações na criação de uma articulação para o estudo da criatividade, 101

\section{CAPÍTULO IV - A PESQUISA, 109}

1. O Contexto da Pesquisa, 110

1.1. A Disciplina "Metodologia do Ensino de Física II", 110

1.2. A Supervisão na disciplina "Metodologia do Ensino de Física II", 114

1.3. Os Sujeitos da Pesquisa, 114

2. A Metodologia da Pesquisa, 115

2.1. Os Portfólios, 117

2.2. As Supervisões da disciplina Metodologia do Ensino de Física II, 118

2.3. Registros de Campo, 119

2.4. As Entrevistas Finais, 120 


\section{CAPÍTULO V - APRESENTAÇÃO E ANÁLISE DOS RESULTADOS, 127}

1. Aspectos Gerais e Objetivos, 128

2. Os Elementos Inerentes ao Processo de Criação dos Estagiários: Os Caminhos Criativos, 134

3. Proposta de Categorização: as perturbações e condutas piagetianas como eixo da análise, 137

4. O Grupo I, 141

4.1. Sujeitos, Contexto e Trajeto do Estágio, 141

4.2. O Caminho Criativo Lacunar, 146

4.2.1. A Organização do Tempo Didático, 147

4.3. O Caminho Criativo Beta, 151

4.3.1. Limitações Impostas pelo Professor Colaborador, 151

4.4. O Caminho Criativo Gama, 155

4.4.1. A Utilização de Recursos Didáticos, 156

4.4.2. A Indisciplina devido à Utilização da Matemática, 162

4.4.3. Aprendendo Com o Que Não Deu Certo, 167

5. O Grupo II, 174

5.1. Sujeitos, Contexto e Trajeto do Estágio, 174

5.2. O Caminho Criativo Alfa, 181

5.2.1. A Participação dos Alunos, 182

5.2.2. A Prática do Professor Colaborador, 186

5.3. O Caminho Criativo Gama, 192

5.3.1. A Avaliação e Indisciplina dos Alunos, 193

5.3.2. A Indisciplina na Sala de Aula, 197

6. Os Processos Criativos e os Conhecimentos Pedagógicos de Conteúdo: síntese e articulações finais, 204

\section{CAPÍTULO VI - CONCLUSÕES E CONSIDERAÇÕES FINAIS, 219}

\section{REFERÊNCIAS BIBLIOGRÁFICAS, 231}

\section{APÊNDICES E ANEXOS, 244}

1. Transcrição Parcial das Reuniões de Supervisão, 245

Estagiários R e C, 245

Estagiários A, L e W, 255

2. Transcrição das Entrevistas Finais, 264

Estagiário R, 264

Estagiário C, 270

Estagiário L, 274

Estagiário A, 278

Estagiário W, 282 
3. Elementos dos Portfólios dos Estagiários, 285

Grupo I, 285

Grupo II, 292 
CAPÍTULO I

ORIGENS DA TESE E SUA

ESTRUTURAÇÃOO 


\section{Origens e Problema de Pesquisa}

Durante três anos, enquanto cursava o programa de mestrado na Faculdade de Educação, argumentei sobre a necessidade de utilização de Histórias em Quadrinhos (HQ) no ensino de física; afinal, tratava-se de um meio pertencente ao cotidiano do aluno, de fácil leitura e formatação universal. Pedagogicamente, expus que os Quadrinhos apresentavam um código próprio que traziam o leitor a participar de seu enredo, o qual, em nosso caso, ainda trazia uma narrativa peculiar, com a inserção de uma situação-problema construtivista que deveria ser respondida pelo estudante para compreender o final da história.

Enfim, meu entusiasmo com a introdução desta nova estratégia era explícito, mas meu principal desafio estava apenas começando - a aplicação da HQ (Figura 1) com os estudantes de níveis fundamentais e médios demonstrou-se um sucesso, mas e os professores? Era necessário explicar aos docentes como utilizar corretamente este elemento em suas aulas, e mais; era preciso incentivá-los a desenhar seus próprios Quadrinhos, assim conseguiriam adaptá-los ao seu planejamento com maior facilidade.

Pelos próximos seis anos continuei a aplicar as Histórias em Quadrinhos já desenhadas por mim com meus alunos e nas aulas de outros professores, constatando, novamente, aquela aprendizagem bem sucedida por parte dos estudantes, fato que já havia verificado por tantas e tantas vezes. Em um dos colégios onde realizava este trabalho, fui convidado pela coordenação a oferecer um mini-curso sobre Histórias em Quadrinhos para os professores de ensino fundamental I e II, o que me incentivou ainda mais a investir neste projeto, inclusive em nível de doutorado - a formação de professores de ciências através da utilização de histórias em quadrinhos. Foi aí que tudo começou... 

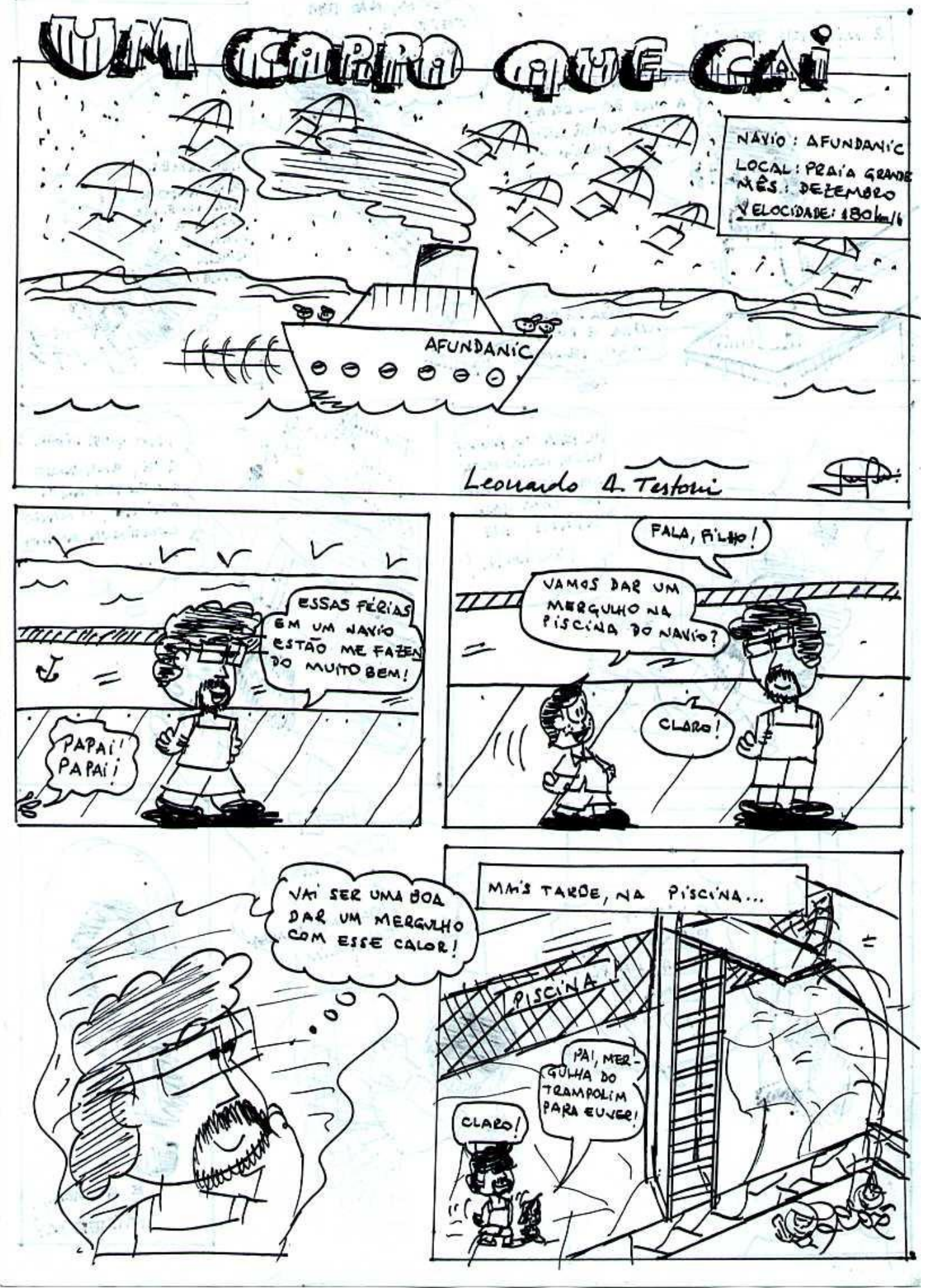

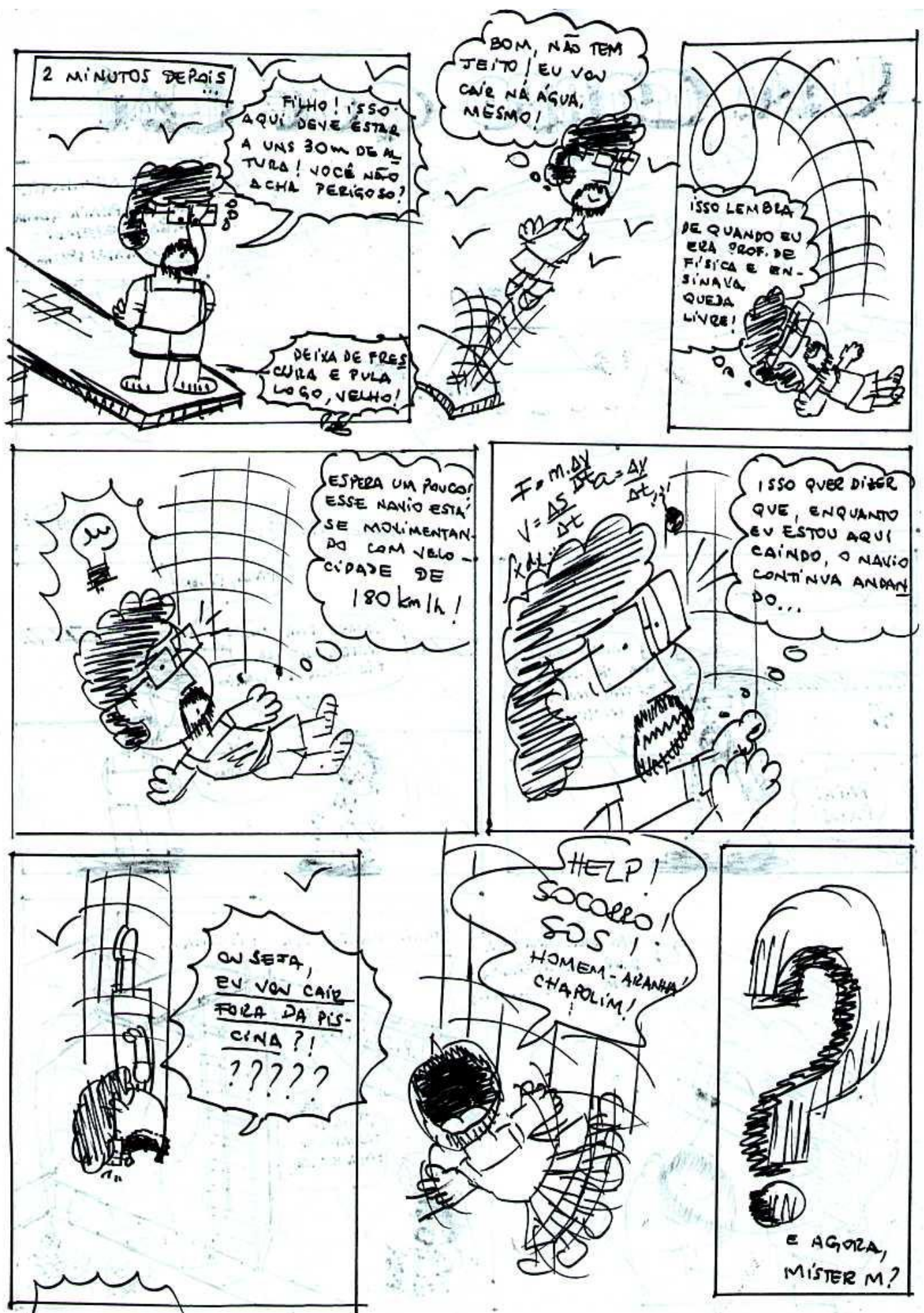

Fig.1 - HQ utilizada (Testoni, 2004) 
Os docentes mostravam-se extremamente receptivos à introdução das Histórias em Quadrinhos em seus planejamentos; entusiasmavam-se quando da projeção dos vídeos que mostravam aplicações dos Quadrinhos em sala de aula, enfim, eles mergulharam neste projeto de um modo que, seu sucesso, a meu ver, era questão de tempo. No término do curso, após três dias inserido no mundo dos Quadrinhos, solicitei aos docentes que produzissem suas próprias HQ para que pudessem aplicar em sala de aula. Como já esperava que a maioria dos professores não tivesse afinidade com o desenho, disponibilizei um software específico (MKGibi) onde, através do computador, os personagens e balões poderiam ser tranquilamente inseridos na narrativa criada pelos autores. Foi a análise destes Quadrinhos que me causou estranheza.

Tanto os docentes que confeccionaram as Histórias em Quadrinhos manualmente, como aqueles que obtiveram auxílio do computador, apresentavam, em sua maioria, narrativas muito próximas daquelas visualizadas em trabalhos realizados por alunos do ensino fundamental, ou seja, o enredo encontrava-se compartimentado, sem dinâmica, sem originalidade, nem humor. Faltavam, também, dinâmicas e poder de síntese, características fundamentais para o sucesso de uma HQ. O fato parecia desabar o projeto - era preciso que os professores conseguissem autonomia na confecção de seus próprios Quadrinhos, caso contrário a adequação do material ao seu planejamento se limitaria àqueles já prontos, que o mercado ou cursos de capacitação ofereceriam. Esta mesma experiência repetiu-se por mais algumas vezes e a questão continuava: por que alguns professores conseguem elaborar roteiros originais, engraçados, chamativos e outros se limitam a reproduzir conteúdos em falas desconexas através de uma narrativa pobre?

Em um aspecto mais geral, parecia-me que a problemática centrava-se sob a criatividade (ou falta dela) do professor no momento em que este deveria, através de uma nova estratégia, desenvolver o processo de ensino, ou seja, elaborar um novo conjunto de informações, representações, ilustrações e analogias que pudessem ser utilizadas em sala de aula a fim de transformar aquele conteúdo a ser abordado em algo mais próximo do entendimento discente, ou seja, um novo Conhecimento Pedagógico de Conteúdo (SHULMAN, 1987).

Com tais indagações, procurei o processo de doutoramento para oficializar estas angústias em uma pesquisa acadêmica, entretanto, a questão agora se apresentava mais aberta do que a inicial - afinal, como classificar uma interação didática como criativa? 
Como a criatividade do professor influencia a produção de sua prática? Que fatores levam um professor a criar interações inovadoras?

De um ponto de vista mais específico, poderíamos sintetizar o objetivo fundamental desta pesquisa como a resposta ao questionamento: como se dão os processos criativos docentes na elaboração de um novo conhecimento pedagógico de conteúdo?

Para responder tal indagação, procuramos, neste trabalho, concentrarmo-nos na análise das elaborações de Conhecimentos Pedagógicos de Conteúdo de futuros professores de Física que cursavam o último semestre da respectiva licenciatura na Universidade de São Paulo .Desta forma, procuramos delinear importantes elementos necessários aos processos criativos dos mesmos, procurando verificar a existência de possíveis trajetos entre os futuros professores em processo de estágio, durante o planejamento de suas aulas, bem como durante sua própria prática em sala de aula, trajetos estes, aqui denominados como Caminhos Criativos.

Assim, procuramos defender nesse trabalho a tese de que a criatividade pode ser desenvolvida, sendo fundamental para o desenvolvimento dos Conhecimentos Pedagógicos de Conteúdo e, consequentemente, essencial para a organização de processos de formação inicial, em especial, o estágio.

A relevância de tais intervenções nos é alicerçada por diversas pesquisas (SHULMAN \& SHULMAN, 2004 e PONTE \& CHAPMAN, 2006, por exemplo) que já relatavam situações onde docentes expostos ao mesmo contexto de formação (escola, cursos de graduação e formação continuada, colegas de trabalho, material didático), apresentavam diferentes elaborações de seus saberes pedagógicos para um mesmo tema a ser lecionado.

Ainda na análise da literatura específica no ensino de ciências e educação em geral, percebem-se recorrentes pedidos da criatividade no trabalho docente (SILVA, 2005), bem como análises já realizadas de que tais docentes criativos relacionam-se positivamente com a aprendizagem de seus alunos (QUEIRÓZ, 2001). Tal posição é também defendida por Pietrocola (2004), para quem, “ a criação se dá no pensamento pela imaginação(...) e é pela imaginação que se atinge níveis mais gerais do conhecimento (...) a ciência, assim como a arte, se apóiam na liberdade de criação 
(p.128)". Nesta mesma linha, Bronowski (1983), ainda aponta o fato do prazer sentido durante a criação:

(...) existe ainda outro aspecto importante: o prazer proporcionado pelas criações. Sentimos prazer em exercitar nossa imaginação (...) é impossível conceber um universo onde as atividades criativas não causem prazer (p.38).

Bronowski (op. cit.) ainda justifica tal fato com as brincadeiras infantis, fatos fundamentais para o desenvolvimento das crianças, pois elas não se cansam de brincar, afinal, estão a criar e lidar com suas criações e representações na imaginação. Neste viés, Pietrocola (op.cit.), defende que "ao aprender a lidar com situações imaginadas, ocorre a preparação para se enfrentar grande parte das adversidades da vida, que requererão a criação de representações para poderem ser solucionadas (p.130)".

Esta recorrente solicitação de um profissional criativo pode ser constatada também nos documentos oficiais que orientam a prática educacional no Brasil, como, por exemplo, os parâmetros curriculares nacionais, onde:

(...) um reequacionamento do papel da educação no mundo contemporâneo (...) coloca a escola em um horizonte mais amplo (...) em um mundo de relações de trabalho $e$ conhecimento que exigem capacidade de iniciativa e inovação. (BRASIL, 1997, grifo nosso).

Uma educação para formar estudantes com capacidade criativa, deve ser orientada por professores com igual capacidade de inovação, não sendo compatível com um fechamento em práticas puramente expositivas e repetitivas.

Ainda no âmago da formação dos docentes, parece-nos de caráter emergencial "a diminuição enorme da distância entre os resultados obtidos ao longo dos últimos 40 anos da produção acadêmica (...) e o ensino veiculado nas salas de aula (ABIB, 2010)". Ainda para Abib (op. cit.), “a superação dessa problemática exige um conjunto de movimentos que leve a articulações entre dois universos ainda muito distantes, ou seja, é necessário que se invista na elaboração de elementos que permitam um diálogo entre diferentes propósitos, conhecimentos, linguagens, contextos de trabalho e condições de produção de conhecimentos sobre ensino".

A autora aponta que, "um caminho que se mostra promissor [na formação de professores] é o aprofundamento das pesquisas sobre a aprendizagem da docência e 
inovações na escola que estimulem a participação criadora, além de práticas que sejam adequadas aos contextos de trabalho e que possam resultar de um movimento de apropriação crítica dos conhecimentos acadêmicos. (p.236)"

Diante deste quadro, em nossa pesquisa, partimos da hipótese de que a criação é uma característica intrínseca de cada docente e que, sua interferência ocorreria durante o processo de transformação do conteúdo disciplinar em conteúdo escolar, ou seja, através do desenvolvimento de seu Conhecimento Pedagógico de Conteúdo (SHULMAN, 1987). Salientamos ainda que, os termos criação, criativo, criatividade, bem como inovação podem apresentar diversos significados no senso comum, o que nos obriga a uma primeira abordagem, demonstrando os significados que serão adotados ao longo deste trabalho.

\section{Criação, Criatividade, Inovação e Escola}

Segundo Vasconcelos (2001), a criatividade é uma função psicológica comum a todos, independente de talento, maturação precoce ou capacidade mental, sendo considerada toda realização humana criadora de algo novo(...), o encontro entre a inteligência e a fantasia.

Em um aspecto geral, Mendes (2005) aponta para o declínio da criatividade, afinal, desde o nascimento se inicia um sutil e inconsciente processo de inibição às interações criativas. Segundo o autor, em pesquisa realizada pela Sociedade Americana de Psicologia entre 1970 e 1985, através de testes utilizados na identificação de cientistas inovadores pela agência espacial norte-americana (NASA), constatou-se um significativo decréscimo na porcentagem de pessoas altamente criativas de acordo com sua faixa etária.

\begin{tabular}{ccc}
\hline Idade (anos) & Pessoas Testadas & Pessoas Altamente Criativas \\
\hline 5 & 1600 & $98 \%$ \\
10 & Mesmo grupo & $30 \%$ \\
15 & Mesmo grupo & $12 \%$ \\
\hline
\end{tabular}

Tabela 1 - extraída de Mendes (2005, p.2) 
De um ponto de vista cronológico, a criatividade já despontava como tema de estudos desde a Grécia Antiga, onde sua existência era ligada à inspiração divina, associada a acessos de loucura e histerismo até o início do século XIX, ou ainda, podendo ser atribuída a forças cósmicas ou vitais, de acordo com a linha filosófica adotada (KNELLER, 1978).

De um ponto de vista psicológico, o processo criativo tenta ser cientificamente explicado a partir de meados do século XIX com a teorias associacionistas de John Locke, para quem as novas ideias eram produzidas a partir das velhas mediante tentativas e erros; passando pelo processo Gestáltico de Max Werthmeier, onde o pensamento criador é a reconstrução de configurações estruturalmente deficientes, atingindo, finalmente, o século XX com Carl Rogers e Guilford em 1960, com suas respectivas teorias psicológicas de auto-realização e análise fatorial (KNELLER, op. cit).

Independente das configurações e caracterizações dadas ao processo criativo nota-se a utilização de diversos termos na designação do processo de criação de algo novo; desta forma, criatividade, criação, processo criativo e inovação acabam por se tornarem sinônimos em uma análise mais descuidada. Entretanto, nesta pesquisa, introduziremos nossa própria visão semântica destes vocábulos, enfatizando sua utilização.

Em nosso ponto de vista, criatividade, conforme utilização no senso comum, costuma referir-se a criações que trazem não apenas novidades, mas sim, onde estas últimas possuem uma função de alta melhora do quadro anterior à sua implementação. Desta forma, com base nas definições de inovação encontradas na literatura da área pedagógica, este termo acaba se confundindo com a definição lato-sensu da criatividade, podendo ser considerados como termos de significados equivalentes. Para validação deste argumento, podemos expor a definição de inovação proposta por Huberman (1976):

[A inovação] é a seleção, organização e utilização criadoras de recursos humanos e materiais, segundo métodos que permitam alcançar um nível mais alto de realização de objetivos previamente fixados (p.16).

Apesar de elegante e, aparentemente simples, o autor destaca que a inovação (ou criatividade, de acordo com nossa definição prévia) é um termo traiçoeiro, enganoso e 
sedutor, pois implica melhoramento e progresso quando, na prática, significa algo novo ou, simplesmente, diferente. Desta forma, ocorre um desvio de atenção da real mudança efetuada em face de, por exemplo, tecnologias. No campo educacional, este fato é muito corriqueiro - quantas vezes já não nos deparamos com inovações educacionais traduzidas na instalação de grades nas janelas ou de um novo laboratório de informática. Ora, se o laboratório não for utilizado de forma criteriosa, reflexiva e voltado para o aprendizado discente, temos o exemplo da introdução de algo novo (uma criação, simplesmente), porém sem efeitos relevantes de progresso nas metas iniciais, não podendo, portanto, ser considerado um processo inovador ou criativo. Corroborando com esta visão, Kneller (1978) já afirmava que " um ato ou uma ideia é criador não apenas por ser novo, mas também porque consegue algo adequado a uma dada situação".

Ainda nesta linha de pensamento, Schon, (1974) apud Huberman (op.cit.) em convergência com Alencar (1995), afirmam que um ato só é inovador se ele aumenta o número de invenções conhecidas, caso contrário trata-se apenas de empréstimos ou de difusões mais amplas do ato inicial, como, por exemplo, um professor que copia uma prática já realizada em outra escola.

Em posição divergente, Ferreti (1980) aponta que as pesquisas em inovação se tornaram mais freqüentes em meados da década de 60, quando se incumbiu à escola a missão de preparar os alunos para as mudanças do mundo moderno. Ainda assim, segundo o autor, a inovação depende do contexto onde a mudança ocorre, não sendo fruto de uma originalidade universal.

As ideias anteriores procuram expor a necessidade de um referencial para a observação de ideias inovadoras (criativas). Segundo Ferreti (op.cit.), uma ideia só é inovadora se o contexto de aplicação desta a considerar como algo novo. Para Stoltz (1999), a noção de criatividade é relativa, dependendo do grupo de referência com o qual a pessoa que cria é comparada - os fatores culturais, portanto, são centrais para a noção de criatividade. Desta forma, ao levar uma estratégia já utilizada de uma escola para outra, o fato seria considerado inovador do ponto de vista da escola receptora. $\mathrm{Na}$ tentativa de convergir os referenciais anteriormente citados, nesta pesquisa abordaremos o ponto de vista do professor em seu desenvolvimento criativo, o que implica que uma ideia, para ser considerada altamente criativa, deva ser original do ponto de vista do docente criador. 
Segundo Morin (2000, p.18), o processo criativo, associado à importância da fantasia e do imaginário no ser humano é imensurável, dado que as vias de entrada e de saída do sistema neurocerebral, que colocam o organismo em conexão direta com o mundo exterior, representam apenas $2 \%$ do conjunto, enquanto $98 \%$ se referem ao funcionamento interno, constituindo-se em um mundo psíquico independente, onde fermentam sonhos, ideias, necessidades, desejos, imagens e fantasias.

O mundo atual encontra-se em constante mudança; o inesperado surpreende-nos a todo o momento. $\mathrm{O}$ ser humano, por instinto próprio, procura instalar-se de maneira segura em suas teorias e ideias, não adquirindo, muitas vezes, estrutura para acolher o novo. Entretanto, quando este inesperado se manifesta, é preciso que o homem seja capaz de rever suas teorias e ideias, em vez de deixar o fato novo entrar à força na teoria incapaz de recebê-lo (MORIN, op. cit.,p.30).

Em educação, as ideias, os hábitos e as estruturas mudam, em geral, de forma muito lenta. Na verdade, segundo Huberman (op.cit., p.09), a história mostra que a educação é um domínio que não patenteia um hiato entre o novo e o velho; os processos são morosos e graduais. A educação trata de instituições sociais e dos adultos que nelas trabalham, o que reforça a resistência à mudança - a busca pela novidade subordina-se ao desejo de estabilidade. Salienta-se, portanto, que " os sistemas escolares, como todos os sistemas humanos, sentem-se impelidos a manter a ordem e a prática estabelecida, apesar de sentirem igual vontade de melhorar e inovar (p.10)".

É neste contexto que a criatividade torna-se peça fundamental na vida do cidadão deste novo milênio - a percepção do contexto global, do multidimensional e do complexo trata-se de meio de sobrevivência; o conhecimento do novo cidadão deve enfrentar a complexidade e seus desafios. Nesta perspectiva, a educação deve favorecer a aptidão natural da mente em formular e resolver problemas essenciais e estimular o uso total da inteligência criativa no enfrentamento do novo, que se altera com frequência.

Reiteradamente, a criatividade é associada como requisito essencial à prática docente. Segundo Xavier (2005), é comum que professores sejam apontados por seus pares como criativos. Tal situação, em geral, é baseada na capacidade destes docentes em sentir problemas, sua disposição para vencer as dificuldades, sua curiosidade, bem como suas ideias empreendedoras, autonomia, além da modificação de práticas para melhoria de aprendizagem. Neste sentido, nota-se a utilização, novamente, do termo 
criatividade em seu senso restrito, onde o docente criativo seria aquele que, simplesmente, apresentaria uma mudança de método ou material didático sem qualquer reflexão crítica acerca da melhoria que o ato poderia propiciar ao processo de ensino e aprendizagem.

Ainda no campo pedagógico, Queiróz (2001) estabelece que a “arte de educar”, mais que uma metáfora, torna-se uma realidade na nova educação solicitada pelas mudanças mundiais. Requer-se cada vez mais um professor rico em recursos técnicos e estéticos, o chamado "docente artista-reflexivo", possuidor de especial competência no uso criativo de modelos pedagógicos.

Em suma, insistimos que no contexto deste projeto, a inovação (aqui com o mesmo significado de criatividade ou processo/ato criativo) requer, além da introdução da novidade no ambiente, sua estabilidade e aumento para níveis mais elevados no tocante aos objetivos de início. Assim, no campo pedagógico, e, mais especificamente, na profissão docente, o ser criativo ou inovador vem como mais uma condição fundamental para a melhoria da aprendizagem discente.

\section{Estrutura do Trabalho}

Com o intuito de caracterizar o processo criativo docente no decorrer da prática didática, fez-se necessário, em um primeiro momento, uma revisão da problemática dos processos de formação docente, procurando enfatizar, de forma ampla, o contexto atual e aspectos gerais acerca do ensino de Ciências e Física, bem como os respectivos cursos de formação inicial. Ainda nesta perspectiva, procuramos abordar a fase pré-docência e os três principais modelos de formação docente (técnico, reflexivo e crítico), salientando suas características no tocante à formação e visões de ensino e aprendizagem sempre em consonância com as interações criativas. Por fim, neste primeiro capítulo, explora-se o significado do conhecimento pedagógico de conteúdo (PCK - Pedagogical Content Knowledge) criado por Shulman (1987), abordando a estrutura do raciocínio pedagógico, onde, segundo nossa hipótese, desenvolve-se a capacidade criativa do professor.

A opção pelo conhecimento pedagógico de conteúdo deu-se devido ao fato deste ser, em nosso ponto de vista, um conceito fundamental para interpretar o âmago do trabalho docente. A transposição do conteúdo científico para seu correspondente escolar 
é a base do ensino, exigindo do professor, além de profundos conhecimentos sobre sua área específica e teorias pedagógicas, uma grande capacidade inovadora para efetuar tal transição. Tal transposição também é estudada por outros autores, com destaque especial para Yves Chevalard que aponta "que o saber não chega à sala de aula tal qual ele foi produzido no contexto científico. Ele passa por um processo de transformação, que implica em lhe dar uma "roupagem didática" para que ele possa ser ensinado". Segundo Matos Filho et. al, 2008,

(...) isso acontece porque os objetivos das comunidades científicas e da escola são diferentes. À Ciência cabe o papel de responder as perguntas que são formuladas $e$ necessárias de serem respondidas em um determinado contexto histórico e social. Por outro lado, esses novos saberes, historicamente construídos pelo homem, precisam ser comunicados à comunidade científica, em um primeiro plano, e, através da escola, à própria sociedade, em um segundo plano.

No segundo capítulo, buscamos fundamentar, teoricamente, o processo criativo como uma atividade exclusivamente humana, sendo, portanto, caracterizado em sua estrutura psicológica, de um ponto de vista biológico-cognitivo, através da epistemologia genética piagetiana e, em seus aspectos sociais, históricos e culturais, mediante o conceito vigotskiano de atividade e seus níveis de criativos.

A psicologia vigotskiana e a teoria da equilibração piagetiana, demonstraramse, em nosso referencial, frutíferas para possíveis análises envolvendo os contextos onde estão inseridos professores criadores; contexto este, cognitivo e social, fundamental para se compreender as intervenções criativas/inovadoras na elaboração de um novo PCK durante os processos de ensino e aprendizagem.

O terceiro e quarto capítulos destinam-se, respectivamente, à metodologia da pesquisa de campo e à análise dos dados obtidos. Desta forma, delinearemos o contexto onde se desenvolve o projeto - o processo de estágio de licenciandos em Física que cursavam a disciplina "Metodologia do Ensino de Física II" - os instrumentos utilizados na tomada dos dados - gravação de aulas, reuniões de supervisão e entrevistas individuais - além da análise do material produzido, procurando delinear as características da criação docente quando da elaboração de sua prática cotidiana. 
O quinto capítulo destina-se às considerações finais e conclusões da pesquisa desenvolvida. Retomando-se os referenciais teóricos e relacionando-os com os dados obtidos no trabalho de campo, procuramos estabelecer as possíveis articulações acerca do trabalho, esmiuçando as condições em que a criatividade pedagógica aflora, além de possíveis implicações que este projeto pode vir a trazer para a melhoria, em um âmbito geral, do Ensino de Física e, em um âmbito mais específico, para a formação inicial de professores desta disciplina. 


\section{CAPÍTULO II}

\section{ASPECTOS FORMATIVOS DO PROFESSOR DE FÍSICA}


Conforme discutido no capítulo anterior, a criatividade vem sendo constantemente solicitada junto ao trabalho docente (SILVA, 2005, p.e.), tornando-se uma característica fundamental ao professor (QUEIRÓZ, 2001). Neste capítulo, partindo da premissa anterior, procura-se, a partir de uma visão global da situação atual do ensino de ciências, analisar de forma geral, a problemática da formação docente, enfatizando, em uma primeira etapa, os modelos profissionais clássicos - técnico, reflexivo e intelectualcrítico - bem como os elementos inerentes ao processo de estágio e a fase pré-docência vivida pelo futuro docente nesse momento. Em um segundo momento, buscamos um relacionamento entre essas características e a coerência com a elaboração de um conhecimento pedagógico de conteúdo (PCK).

A título de síntese, apresentamos o interrelacionamento entre o PCK elaborado e o processo criativo docente do ponto de vista da criação de interações inovadoras em ambiente escolar por parte do professor.

\section{Aspectos Gerais do Ensino de Física}

O panorama geral do ensino de Ciências no mundo parece estar seguindo para um crescente distanciamento entre o que o professor pretende ensinar e aquilo que, efetivamente, é assimilado pelo aluno. Segundo Carvalho (2009), poucos são os estudantes que realmente aprenderam em suas aulas de Matemática, Física, Química ou Biologia; quando muito, conseguem uma vaga lembrança de um ou outro conceito visto, porém, sem conseguir aplicá-lo ou explicá-lo. Ainda segundo outras revisões já realizadas na literatura específica (CARVALHO, 2000 E GUIMARÃES, 1987, por exemplo), constata-se que a Física, por exemplo, continua sendo ensinada de forma compartimentada e isolada, sem articulação com as demais áreas do conhecimento e ainda fortemente ligada ao método expositivo aliado ao mecanicismo matemático (CARMO, 2009), esquecendo-se da exploração dos fenômenos e levantamento das hipóteses, atividades tão importantes na construção dos conhecimentos científicos.

Em corroboração com a citação anterior, é fato que a educação científica, enquanto "conhecimentos transmitidos pela escola" trata os alunos de maneira igual, mas “essa mesma escola não é capaz de apontar as diferenças entre os mesmos, quando da realização das avaliações (BICUDO, 2005, p.15). 
A área de Ciências (onde se encontra a Física) vem, tradicionalmente, sendo ensinada com pouca referência à sua construção. Medeiros (2005) afirma que o fato de professores e alunos agirem sem uma clara percepção de suas ações e significados extrapolam os muros escolares, atingindo, inclusive, a universidade:

O ensino (...) é reduzido à exposição de conteúdos $e$ resolução de problemas-modelo, feitos pelo professor, para o aluno (p.18, grifo da autora). Mesmo na universidade, os problemas-modelo continuam existindo, com a diferença de que, nas avaliações, além deste são cobradas soluções de problemas fora dos padrões.

Desta forma, constata-se uma possível tendência principal, onde a forma de ensinar os conteúdos científicos se repete nos mais diversos níveis, porém, cobra-se o tradicional e a criatividade, "como se esta última pudesse surgir repentinamente para os alunos acostumados à passividade, em uma escola em que a transmissão unilateral dos conteúdos sempre prepondera sobre a construção do conhecimento (Medeiros, op. cit., p.19)".

Diante deste panorama geral, infere-se acerca de uma possível situação de crise na educação científica, onde o aluno torna-se um exímio manipulador de símbolos em situações padronizadas:

Há uns quinze anos, eu não ousaria dizer que o ensino ${ }^{l}$ (...) estava em crise. Contentava-me por dizer que era a minha opinião. Hoje quando todo o mundo em meu país o afirma como evidente (...) eu me sinto menos ridículo dizendo a mesma coisa (...) creio que se pode razoavelmente afirmar que esta é a situação no mundo industrializado. (FOUREZ, 2003, p.109)

Baseado no quadro descrito, os professores de Física, bem como os demais docentes da área científica, alunos, dirigentes econômicos, pais e cidadãos, encontramse meio a esta situação indefinida, apresentando, muitas vezes, interesses e objetivos conflitantes no tocante à educação em ciências.

Segundo MATHEWS, 1991 apud CARVALHO, op.cit., o que este tipo de ensino transmite são visões empírico-indutivistas, que se distanciam largamente de como se constroem e se produzem os conhecimentos científicos. Segundo DRIVER et 
al, 1999, “(...) é preciso que o estudante consiga ver algum sentido no conjunto de teorizações feitas pelo professor e, principalmente, que compreenda a disciplina a ser ministrada como uma forma diferente de pensar e falar sobre o mundo, sendo esta entendida como uma cultura própria, com suas regras, valores e linguagens específicas.”. Na mesma linha, particularmente na educação científica, Fourez (op.cit.), aponta uma interessante análise, onde os alunos teriam a impressão de se quer obrigálos a ver o mundo com os olhos dos cientistas, enquanto o que teria sentido para eles seria um ensino de ciências que os ajudassem a compreender o mundo:

(...) perto do que fazia minha geração, os jovens de hoje parecem que não aceitam mais se engajar em um processo que se lhes quer impor sem que tenham sido antes convencidos de que esta via é interessante(...) [os jovens] pedem que thes seja mostrado, de início, a importância cultural, social ou econômica de fazer este desvio. (p.110)

De acordo com o exposto, é possível inferir que uma tendência do quadro geral do ensino de Física, em um âmbito global, apesar do lapso temporal existente entre as citações anteriores e o tempo presente, não sofreu mudanças significativas, de um modo geral. Ainda se mostra uma prática de aula baseada no método puramente expositivo, com o professor cumprindo uma grande gama de conteúdos, muitas vezes desarticulados em relação à própria ciência, à matemática e a realidade discente, enfatizando principalmente o uso de fórmulas e resolução repetitiva de exercíciospadrão, que mais procuram conhecimentos de cálculo do que uma compreensão do fenômeno em questão.

Do ponto de vista metodológico, Abib (1997), ao criticar a concepção tradicional de ensino, coloca que neste formato "basta que o professor explique bem para que a transmissão do conhecimento ocorra(...) transparece a ideia de que o aluno vai à aula para receber conhecimentos”. Fica claro a posição receptiva/passiva do discente, enquanto que o conhecimento fica totalmente centrado na figura do professor. Um pressuposto básico desta forma tradicional de ensino é a expectativa de que aluno e professor estejam em um mesmo patamar conceitual, o que na maioria das vezes não ocorre. O resultado obtido com este tipo de metodologia é a simples memorização de fórmulas e fatos que não possuem nenhum significado para o aluno. Nesta situação, tão 
importante quanto à questão da aprendizagem do estudante é a formação do professor inserido neste processo.

\section{Aspectos Formativos do Professor de Física: um breve contexto}

Os professores vêem-se diante de uma crise escolar que culmina com sua perda de poder e consideração de sua profissão. Os professores de Física, em um caráter mais particular, deparam-se ainda com suas próprias questões, tendo que mostrar aos alunos o sentido que pode haver no estudo desta ciência, estabelecendo constantes relações entre sua disciplina e outros componentes curriculares em uma perspectiva interdisciplinar, além de buscar os possíveis entrelaçamentos com questões sociais, econômicas, culturais e ambientais, agora em uma perspectiva C/T/S/A. Diante desta situação, o questionamento principal não poderia deixar de ser: a formação atual dos professores de Física é suficiente para vencer estes desafios impostos por esta nova educação?

Segundo Abib (1996), através de uma vasta análise da literatura específica da área, é possível identificar três grandes problemas que atingem a formação inicial dos professores:

a) Desarticulação entre teoria e prática: fundamentada no modelo de racionalidade técnica, onde a prática profissional consiste na solução instrumental de problemas mediante a aplicação de conhecimentos teóricos, o professor é concebido como um técnico executor de tarefas, explicitando-se em sua formação curricular, disciplinas e áreas estanques de conteúdos específicos e pedagógicos.

b) Falta de articulação entre universidade e escolas de educação básica: inspirada na grande importância dada aos conhecimentos advindos da prática profissional dos docentes, culmina na separação drástica entre a formação inicial e o trabalho, contribuindo, muitas vezes, para a entrada de professores no mercado de trabalho que não possuíram contato com o ambiente escolar real.

c) Desvalorização profissional do professor e dos cursos de licenciatura: a pequena importância atribuída pelas universidades aos cursos de formação docente, reflete no processo de evolução destes profissionais que serão inseridos em um 
mercado que os consideram como selecionados negativamente - pessoas menos preparadas dirigem-se à carreira, que tem baixa remuneração e prestígio social.

Como resultado desta atual configuração dos cursos de licenciatura, os professores de Física acabam por apresentar uma série de características comuns, consequência da problemática exposta anteriormente. Assim, em sala de aula, de modo geral, constatamos a existência de um docente que reproduz a prática aprendida, desarticulando conteúdos em seu ensino, centrando sua prática em abordagens tradicionais (MIZUKAMI, 1986), onde a transmissão verbal e central do docente é considerada suficiente para que o aluno assimile os conceitos abordados, apresentando uma postura acrítica, desesperançosa e resistente a inovações, além de não se dar conta do papel político que apresenta, conforme exposto em Freire (2006).

Com base na situação exposta, a necessidade de mudanças no processo formativo dos docentes, em caráter geral, e para a educação em Física, em um aspecto mais específico, fica evidente. As alterações nas propostas formativas do professorado emergem nas pesquisas realizadas na área, sendo apresentados a seguir alguns dos pontos fundamentais sintetizados por Abib (op.cit.):

a) Deve-se posicionar o futuro professor como investigador de sua própria prática pedagógica;

b) Criar condições para que o futuro professor inicie o mais cedo possível sua prática em sala de aula;

c) Considerar as concepções que os futuros professores apresentam acerca de do ensino, aprendizagem e conhecimento (como também apontado em PORLÁN, 1997);

d) Organizar cursos de formação que promovam aos professores evoluções conceituais, metodológicas e atitudinais;

e) Ainda nos cursos de formação de professores, adotar metodologias adequadas e coerentes com os princípios veiculados;

f) Considerar os aspectos afetivos em íntima relação com os cognitivos;

g) Utilizar a metacognição como uma das formas de propiciar a análise e evolução das concepções e práticas docentes. 
Ainda nesta linha de possíveis soluções para a formação dos professores, Fourez (op.cit.) também argumenta a necessidade de se mesclar os sólidos conhecimentos da disciplina específica de formação com os conhecimentos didáticos, não se esquecendo da epistemologia e história da disciplina.

Em uma interpretação mais profunda que àquela proposta por Fourez, Tardif (2002) salienta a importância de um conjunto de conhecimentos específicos da atividade docente, que passa por um processo evolutivo no decorrer da formação do professor, os chamados saberes docentes. Tais conjuntos organizam-se em quatro grupos: os saberes profissionais, que correspondem aos conhecimentos relativos à ciência da educação, tais como didática, psicologia, estruturas de políticas públicas, entre outros; os saberes disciplinares, que se referem aos conteúdos específicos da disciplina ministrada pelo professor como, por exemplo, no caso de um professor de física, pode-se citar os fundamentos da mecânica, eletricidade, óptica, mas sem esquecer que, dentro destes conteúdos co-existem as dimensões históricas e epistemológicas de cada tópico; os saberes curriculares, onde encontram-se os aspectos relacionados à currículo, programas, parâmetros e afins; e o as saberes experienciais, que remetem à construção de repertórios específicos oriundos da prática cotidiana docente.

Na mesma visão, Gauthier também aponta a extrema importância dos saberes dos professores, bem como sua conscientização e evolução nos processos de formação. Para este autor:

[os saberes docentes] são exibidos pelos professores em
ação na sala de aula, escola e comunidade
educacional(...)são uma espécie de reservatório no qual se
abastecem [os professores] para responder a exigências
específicas de situações de seu cotidiano profissional. Este
reservatório é dinâmico, passando por mudanças em
função das experiências novas. (GAUTHIER,1998, p.3)

$\mathrm{Na}$ formulação de Gauthier, encontram-se saberes correspondentes àqueles trazidos por Tardif, ocorrendo apenas a variação nominal no tocante ao saber profissional do primeiro autor, chamado de saber relativo às ciências da educação, por Gauthier. Entretanto, este último autor busca um maior delineamento na classificação dos saberes dos professores, adicionando ainda os saberes relativos à ação pedagógica e à tradição pedagógica. O primeiro deles trabalha com a visão de que a profissão docente apresenta uma característica específica - o futuro professor, mesmo que ingressante em 
um curso de formação inicial, apresenta uma sequência de ideias já incorporadas relativa às mais de 16000 horas que permaneceu nos bancos escolares, sendo possível construir sua própria concepção a respeito das ações (atitudes e procedimentos) que remetem à sua visão específica da profissão docente. O segundo saber aponta para um arsenal de respostas formuladas a situações repetitivas do cotidiano escolar, as quais foram criadas pelo professor no decorrer de seu processo profissional, tornando-se uma espécie de tradição em seu trabalho.

Tão importante como identificar as características dos saberes docentes relativos a uma determinada fase da formação do professor, é possuir consciência de que eles não apresentam um conjunto fixo de ideias, dependendo, fundamentalmente, da visão de docência, ensino, aprendizagem, ciência e conhecimento que este futuro professor foi submetido durante toda sua vida. Tais visões acabam por influenciar o desenvolvimento do futuro docente já em sua formação inicial, de acordo com os modelos empregados em sua formação, conforme discutido a seguir.

\section{Os Modelos Formativos Profissionais}

De acordo com a classificação proposta por Contreras (2002), o professor, como categoria profissional, apresenta três características principais: a obrigação moral, que se refere à importância dos atos éticos e legítimos durante sua atuação, o compromisso com a comunidade, enfatizando-se a questão social do trabalho docente, enquanto atuante dentro dos círculos sociais presentes à escola e a competência profissional, aqui compreendida como o conjunto de saberes necessários à atuação docente em excelência.

Com base nestas três vertentes, o autor estabelece três modelos formativos onde os se enquadrariam os docentes no momento atual.

\subsection{O Técnico}

Baseado no princípio da racionalidade técnica, este paradigma profissional procura ver a prática como a solução instrumental de problemas mediante a aplicação de um conhecimento teórico previamente transmitido (e disponível) que provém da pesquisa científica pura nos campos específicos (Física, por exemplo) e nas ciências de educação. 
Segundo Contreras (op.cit.), [a função do professor] é a aplicação de técnicas e procedimentos que se justificam por sua capacidade para conseguir os efeitos ou resultados desejados (p.91). Neste formato, a docência apresenta três características básicas: 1) uma ciência ou disciplina básica; 2) uma ciência aplicada ou engenharia; 3) habilidades ou atitudes, sendo estas últimas classificadas de maneira hierárquica na visão do modelo:

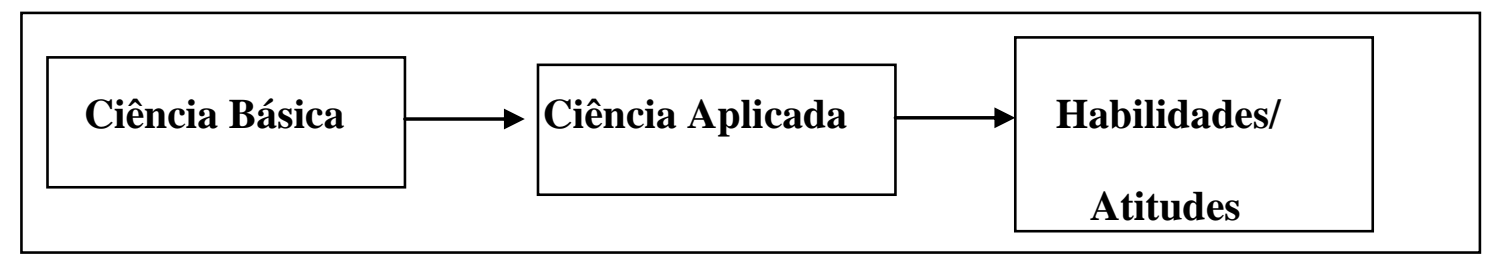

Fig.2 - Hierarquia no modelo técnico

No modelo de professor como profissional técnico, os fins do processo são extremamente bem fixados e definidos, o que infere a posição docente como um aplicador de procedimentos, regras e meios técnicos visando a obtenção dos resultados almejados através da prática profissional acrítica. Em uma aberta dicotomia pesquisador - técnico, o docente não apresenta habilidades para elaboração dos processos realizados, mas apenas sua aplicação. Desta forma, a perícia do professor é estabelecida através dos métodos transmitidos a ele em sua formação inicial e permanente, ambas com característica de treinamento, no sentido de pura transmissão dos conteúdos e técnicas a serem utilizadas em situações previamente elaboradas

Como principal consequência deste tipo de formação, pode-se claramente vislumbrar que o perfil do professor estará muito próximo da abordagem tradicional de ensino (MIZUKAMI,1988), onde espera-se um docente que veja seu aluno como uma tábula rasa, na qual as informações serão bancariamente depositadas (FREIRE, 2002) no decorrer de sua educação, a qual apresenta um enfoque intelectual e é considerada como produto final, sem ênfase nos processos

O professor formado segundo o modelo técnico também apresentará um perfil desarticulado entre as áreas de seu próprio conhecimento e na cultura geral (reproduzindo sua própria formação), procurando a transmissão destes conteúdos de forma frequentemente expositiva, sendo ele o agente principal da prática escolar e do sistema avaliativo que visa a memorização dos tópicos abordados.

Em suma, para Abib (2010), no modelo de racionalidade técnica, a característica fundamental é a primazia da teoria sobre a prática, ou seja, mera aplicação racional da 
ciência; as questões educacionais podem ser resolvidas objetivamente com o uso de técnicas industriais.

\section{2. $\underline{\text { O Professor Reflexivo }}$}

A docência, como vários outros campos profissionais, aponta na repetição como fator considerável na experiência cotidiana. Um profissional é um especialista que enfrenta repetidamente determinados tipos de situações. De acordo com o modelo tecnicista docente, tais situações, quando defrontadas, são consideradas em função da semelhança com casos anteriores. Como produto da repetição, o professor desenvolve um repertório de expectativas, imagens e técnicas; conforme a prática se torna estável e repetitiva, seu conhecimento acaba por se tornar mais espontâneo.

A limitação da visão citada se dá quando da ocorrência de novos casos, nunca tratados pelo profissional. Com estas novas ocorrências, o repertório parece insuficiente, obrigando o docente a refletir sobre as peculiaridades do momento imposto, requere-se a criação de novas perspectivas, momento onde o modelo de racionalidade técnica se torna inviável - como resolver e tratar o imprevisível? Para iniciar a busca à solução, a profissão docente deve ser observada pelo referencial da racionalidade prática, teoria onde, Aristóteles distingue as atividades técnicas, que se dirigem à produção e obtenção de resultados diferentes da coisa inicial e as atividades práticas, que se realizariam na própria ação através dos valores considerados corretos, definidos pela prudência de um pensamento reflexivo durante a ação.

Face ao exposto, torna-se latente a necessidade de resgatar a base reflexiva da atuação profissional para se entender a forma com que se abordam situações problemáticas da prática - o modelo reflexivo docente (SCHÖN, 1992). Segundo o autor, a prática profissional do professor se reduz a dois momentos gerais: o primeiro, chamado conhecimento-na-ação, engloba todas as ações docentes realizadas espontaneamente, seja por sua simplicidade, seja por sua repetição durante a carreira; o segundo, concebido como a reflexão-na-ação, aborda as situações não habituais, onde se faz necessário o pensar sobre o que fazemos, enquanto fazemos. Neste caso, a reflexão propiciará que tal situação problemática entre para o repertório do profissional, provavelmente transformando-se em conhecimento-na-ação na próxima vez que ocorrer um caso similar. 
O processo reflexivo não é, necessariamente, algo pontual e rápido; ele transforma o profissional em um "pesquisador no contexto da prática" :

(...) nestas ocasiões, os práticos demonstram sua "arte profissional", manipulando grande quantidade de informação, selecionando traços relevantes, extraindo consequências (SCHÖN, 1992, p.110)

Vale ressaltar que, diante deste modelo, a prática não se abre para a resolução de problemas com determinados fins, mas também à reflexão de quais devem ser os fins a serem estipulados. Portanto, a prática reflexiva se encaixa mal em contextos de burocratização e controle, onde as metas de encontram previamente definidas à margem dos problemas concretos e reais enfrentados pelos professores. Em geral, os problemas que demandam atitudes reflexivas dos profissionais são aqueles para os quais não são válidas as soluções acumuladas, iniciando a espiral "avaliação - ação - nova avaliação" (SCHÖN, 1992, p.132).

Apesar da coerência interna da proposta do modelo reflexivo na formação profissional docente, é preciso cautela na utilização do termo profissional reflexivo, visando uma não banalização do mesmo em atividades que não se incluam nesta linha de pensamento. Na própria literatura específica da área, ZEICHNER (2002) identifica cinco formas de "práticas reflexivas", sintetizadas abaixo:

a) versão acadêmica: tradução do conhecimento disciplinar em matérias escolares.

b) versão eficiência social: aplicação de estratégias de ensino externas aos praticantes, normalmente formuladas por pesquisadores em educação.

c) versão reconstrução social: reflexão sobre os contextos institucionais, sociais e políticos.

d) versão genérica: reflexões em geral, sem especificidades.

Apesar desta variedade de concepções acerca da reflexividade docente, os próprios precursores desta vertente teórica acerca do trabalho do professor (Schön e Stenhouse) apontam características específicas do processo reflexivo que devem ser consideradas para realmente classificá-lo como tal, conforme apontado por Contreras (2002): 
a) Os professores reflexivos elaboram compreensões específicas dos casos problemáticos no próprio processo de atuação;

b) O processo [reflexivo] inclui a deliberação sobre o sentido e valor educativo das situações, meditação sobre as finalidades, realização de ações práticas consistentes com tais finalidades e valores educativos, além da valorização argumentada das consequências do processo;

c) O profissional acaba por construir um conhecimento profissional específico e capacidade de desenvolver-se nas situações de conflito;

d) A prática reflexiva gera a capacidade de deliberação moral sobre o ensino (resultados consistentes com as pretensões educacionais);

Em síntese, pode-se expor que o professor como indivíduo reflexivo deve guiar-se pelos valores educativos pessoalmente assumidos, negociar e equilibrar os interesses de cunho social e político, ter a competência profissional para pesquisar e refletir sobre sua prática (deliberando na incerteza acerca da forma moral ou educativamente correta de agir em cada caso). Tal quadro permite inferir que tal profissional apresenta uma autonomia no tocante à responsabilidade moral individual, considerando os diferentes pontos de vista. Além disso, caracteriza-se, aqui, um docente com capacidade para resolver criativamente as situações-problema apresentadas pelo cotidiano da sala de aula, obtendo realizações práticas das pretensões educativas.

Abib (2010) esclarece, a título de síntese, que os fracassos recorrentes nos programas de formação de professores centrados no modelo técnico, bem como a já citada imprevisibilidade do trabalho docente geram a defesa da epistemologia prática, onde as reflexões dos professores sobre seu trabalho constituem o cerne dos processos de geração dos conhecimentos profissionais, o que sugere um processo de investigação permanente sobre suas próprias ações na sala de aula. Nesta linha, os docentes são pesquisadores de sua prática, conferindo uma dimensão investigativa e criadora da função docente. 


\section{3. $\quad$ O Intelectual Crítico}

Uma das principais críticas (ZEICHNER, op.cit., por exemplo) colocadas sobre o modelo do professor reflexivo é o fechamento deste profissional em sua sala de aula, isolado dos contextos sociais, políticos e econômicos que circundam o ambiente e comunidade escolar.

Visando à complementação dos modelos técnico e reflexivo, a proposta do professor como um intelectual crítico traz um docente que busca um ensino dirigido à emancipação individual e social, tal qual a professada por Freire (2002), guiada pelos valores da racionalidade, justiça e satisfação.Do ponto de vista da comunidade escolar, este modelo formativo busca inserir o docente em um processo de defesa dos valores para o bem comum (justiça e igualdade, por exemplo), além de sua participação em movimentos sociais pela democratização.

$\mathrm{Na}$ esfera da competência profissional, este intelectual crítico deve desenvolver a auto-reflexão sobre as distorções ideológicas e os fatores condicionantes institucionais, desenvolvendo uma análise e crítica social, a qual poderá corroborar com uma participação na ação política transformadora. Segundo Contreras (op.cit.), esta tipificação docente apresenta a autonomia como emancipação: liberação profissional e social das opressões. Ainda segundo o autor, o intelectual crítico é autônomo em caráter coletivo (configuração discursiva de uma vontade comum), a ponto de superar as distorções ideológicas, apresentar consciência crítica do processo educacional, bem como dirigir-se à transformação das condições institucionais e sociais do ensino. Em um aspecto mais geral, não se pode consignar a respeito da separação entre os modelos formativos apresentados, haja visto existir entre eles, pontos de intersecção, necessários à atividade docente.

É inviável, portanto, se pensar em um professor no patamar intelectual crítico que, em algum momento de sua atuação profissional não se tenha deparado com situações já conhecidas que exigiam um conhecimento previamente elaborado nas pesquisas em educação (modelo técnico) ou que tenha se deparado com uma situação inédita de sala de aula, que exigiu uma reflexão imediata e fechada no espaço físico escolar. Desta forma, pode-se inferir acerca de uma evolução docente no que diz respeito a sua autonomia, desde um técnico reprodutor de conhecimentos e metodologias previamente elaborados por um agente externo ao ambiente da sala de aula, passando por atitudes reflexivas referentes às situações inéditas do ambiente 
escolar não constante nos "manuais" já existentes e, culminando com a capacidade de tratar a educação como uma prática emancipatória de caráter social e político, onde os velhos manuais e a reflexão na ação não podem ser excluídos, mas adicionados ao processo. Ressalta-se que, não menos importante que a classificação profissional docente em categorias relativas ao seu comportamento perante o sistema escolar, é a competência do professor em utilizar sua autonomia e reflexão na construção daquilo a ser ensinado - o conteúdo pedagógico.

Em ação convergente, Diniz-Pereira (2002), “esclarece que os modelos técnicos têm uma concepção instrumental sobre o levantamento de problemas; os práticos têm uma perspectiva mais interpretativa e os modelos críticos têm uma visão política sobre o assunto (p.29)". Ainda para o autor, no modelo de racionalidade crítica, a educação é historicamente localizada - ela acontece contra um pano de fundo sócio-histórico, o que nos remete a uma atividade social, política e problemática - “ O professor é, frequentemente, definido como alguém que levanta problemas e dirige diálogos críticos em sala de aula; levantamento de problemas é sinônimo de pedagogia (p.30)".

Como aponta Porlán (1997), em um modelo docente crítico, as ideias e condutas das pessoas e dos processos de contraste e comunicação das mesmas não são neutros (...) [os processos] de construção de significados apresentam uma visão mais complexa dos fenômenos da realidade, sendo uma condição necessária para desenvolver determinados valores em alunos e professores (autonomia, cooperação, respeito, participação, (...) justiça e harmonia). Neste sentido, os objetos-problema da investigação devem responder a critérios mais amplos que aqueles estritamente acadêmicos(...) favorecendo o surgimento de dilemas intelectuais, éticos e ideológicos (p.157).

Para Abib (2010), os modelos práticos ficam circunscritos à dinâmica individual do professor, não dando a devida ênfase ao papel do docente enquanto agente de transformação social. Neste modelo de racionalidade crítica, os modelos políticos e sociais do magistério são colocados em posição central - “ a pesquisa busca uma melhoria da sociedade" (p.229). Ainda na visão da autora, uma das principais contribuições desta abordagem crítica, é a proposição da pesquisa-ação com caráter emancipatório.

Surgido em meados da década de 40 com Kurt Lewin, o conceito de pesquisaação procura expor uma combinação entre experimentação científica e aplicação social. 
Os traços essenciais eram a conceituação de problemas, planejamento, execução e avaliação de ações para resolvê-las, seguida de repetição do ciclo (ULLMAN, 2000). A pesquisa,portanto,se desenvolve com a participação dos próprios sujeitos estudados, resolvendo problemas no ambiente onde eles ocorrem.

A partir de meados do século XX, a pesquisa-ação começa a apresentar um viés educacional,sendo amplamente utilizada em escolas e cursos de formação de professores, visando a, cientificamente, estudar os problemas pedagógicos de modo a orientar, corrigir e avaliar suas ações e decisões (ANDRÉ, 2000). Como aponta Jordão (2005), trinta anos após a implementação desta forma de pesquisa, Laurence Stenhouse e outros pesquisadores da área educacional começam a estimular os professores a assumirem uma participação ativa na elaboração, implementação e análise curricular dos locais onde lecionavam, possibilitando, desta forma, uma maior autonomia a estes docentes, beneficiando seus alunos e seu próprio desenvolvimento profissional.

Atualmente, a pesquisa-ação, devido às contribuições dos modelos de racionalidade crítica, já descritos, procura uma prática pedagógica como uma práxis social emancipatória, ou seja, uma investigação auto-reflexiva, realizada pelos professores para melhorar a compreensão, racionalidade e justiça de suas próprias práticas. Segundo Carr e Kemmin (1998) apud Jordão (op. cit.), o elemento desencadeador da pesquisa-ação deve ser a crítica institucional e social, a partir da qual se compreende melhor a situação de sala de aula. Já para Zeichner (2002) apud DinizPereira (2002), a pesquisa-ação deve fazer com que o professor pesquise, aja, observe e reflita sobre sua prática em uma perspectiva multicultural e emancipatória, enfatizando os contextos sociais, políticos, morais e éticos.

A seguir, exporemos alguns elementos referentes aos processos de formação inicial e estágio e suas relações com os modelos formativos discutidos até o momento.

\section{Formação Inicial e Processo de Estágio: demandas atuais}

Conforme já apontado por Morin (2000), a sociedade atual é caracterizada pela complexidade e interrelacionamento entre seus indivíduos. Tal complexidade acaba por se refletir no papel da escola, que enfrenta desafios que vão desde atender às demandas de eficácia na lógica da qualidade, que trata o capital humano como mercadoria em uma 
escada de ascensão social, até a democratização e respeito à diversidade (CHARLOT, 2007).

Segundo Moraes (2010), os professores, no contexto descrito anteriormente, acabam por ganhar importante papel nessa sociedade de aprendizagem, onde a capacidade do aluno aprender remete-se à qualidade da formação atribuída aos docentes, um dos focos de críticas recorrentes. Segundo a autora,

"É inegável a estreita relação que existe entre o desempenho do professor e o indice de aproveitamento de seus alunos $e$, consequentemente, entre sua formação profissional $e$ as instituições encarregadas de desenvolvê-la (p.22)".

Entretanto, segundo Santos (2009), “as novas concepções sobre educação, ensino e aprendizagem, aliadas ao impacto produzido pelas tecnologias de informação, vem delineando (...) novas exigências, cujo atendimento os professores não foam suficientemente preparados (p.40)". Ainda segundo a autora, diante dessas demandas, faz-se necessária uma revisão profunda nos modelos de formação de professores.

A formação inicial docente, em um contexto universitário, surge em 1937 com a abertura dos primeiros cursos de licenciaturas, formando profissionais para o ensino básico. Entretanto, tais cursos, cuja estrutura em algumas instituições perdura até hoje, eram compostos pelo sistema $(3+1)$, onde as disciplinas pedagógicas eram ministradas no ano final, sendo os três primeiros destinados ao aprendizado de conteúdos específicos na área de formação escolhida.

Segundo Krasilchik (1987), esta linha de formação, que oferecia poucos conhecimentos específicos ao magistério e à realização de aulas experimentais, além de grande dependência do livro didático por parte do formando, é, praticamente, unânime entre os modelos de formação docente, mantendo-se até o início dos anos de 1990.

Dessa forma, em uma sociedade contemporânea onde a prática pedagógica vem sendo desafiada pela complexidade, pelo incerto e o inesperado, a formação docente encontra-se diante da necessidade de uma reformulação, que busque o desenvolvimento de um professor com uma visão crítica, reflexiva e transformadora (MORAES, p.24).

Em ressonância com os modelos formativos abordados no tópico anterior,

\footnotetext{
“as propostas mais recentes e promissoras são aquelas que seguem matrizes crítico-reflexivas (...) com
} 
enfoques sobre propostas que visam à construção de modelos de formação, onde o saber sobre o ensino deixa de ser visto sob a ótica de treinamento e capacitação, passando a incorporar uma formação mais abrangente, onde o futuro professor torna-se responsável pela construção de seu conhecimento (...) através da reflexão sobre sua prática (MORAES, op.cit., p.25).

De fato, tal visão crítico-reflexiva nos é corroborada por Pimenta (2008), para quem a formação inicial, antes realizada em uma perspectiva técnica, voltou-se para a necessidade de se formar profissionais capazes de ensinar em situações singulares, incertas, carregadas de conflitos e dilemas, que caracteriza o ensino como prática social em contextos historicamente situados.

Entretanto, segundo Abib (2002), a organização curricular tradicional, ainda presente na grande maioria dos cursos de licenciatura das universidades brasileiras, pressupõe que após a aquisição dos conhecimentos teóricos fundamentais, a prática, vista como uma aplicação destes últimos, garantiria o "aprender a ensinar", revelando um enfoque de formação voltado essencialmente ao modelo de racionalidade técnica.

Apontando para uma mudança deste quadro, em 18 de dezembro de 2002, o Ministério da Educação publica a resolução CNE/CP (BRASIL, 2002), onde se institui as diretrizes curriculares nacionais para a formação de professores de educação básica. Neste documento, segundo Santos (op. cit.) são encontradas orientações gerais que apontam na direção de mudanças na formação docente e ao atendimento às necessidades atuais da educação brasileira, pois

A preparação do professor tem uma peculiaridade muito importante: ele aprende a profissão em um lugar similar àquele em que vai atuar (...) implicando na necessidade de uma coerência entre o que ele faz na formação e o que dele se espera no exercício da profissão (p.44).

Portanto, a prática do futuro professor, obtida, em um primeiro momento, junto aos processos de estágios obrigatórios vinculados aos cursos de licenciatura, devem se afastar desse formato tradicional. Nessa linha, segundo Aroeira (2009), tal formato não tem contribuído para favorecer a análise critica da prática docente em sala de aula, nem tem conseguido formar uma atitude docente que supere tal perspectiva técnica e conservadora, não superando a dicotomia entre teoria e prática. 
Nesse sentido, com o objetivo de manter tal articulação entre os conhecimentos teóricos e aqueles de caráter experiencial, a resolução CNE/CP (2002) amplia a carga horária mínima dos cursos de licenciatura para 2800h, sendo estas divididas da seguinte forma:

a) 400h de prática como componente curricular, vivenciadas ao longo de todo curso de graduação.

b) $400 \mathrm{~h}$ de estágio curricular supervisionado, podendo ser iniciado a partir da segunda metade do curso.

c) $1800 \mathrm{~h}$ destinadas aos conteúdos curriculares de natureza científico-cultural.

d) 200h para outras atividades acadêmico-científico-culturais.

Desse modo, a legislação recente prevê que o futuro professor disponha de, ao menos, $800 \mathrm{~h}$ de atividades ligadas à prática, possibilitando ao futuro professor uma maior possibilidade de construção daqueles conhecimentos experienciais necessários ao exercício da profissão. O mesmo documento (BRASIL, 2002) prevê a possibilidade de flexibilização, face às especificidades de cada instituição formadora, sempre com o objetivo de inovação na construção de seus projetos pedagógicos.

Nesse sentido, a Universidade de São Paulo ${ }^{1}$, particularmente, em um movimento de reformulação de seus cursos de licenciatura, publica o seu Programa de Formação de Professores (USP, 2004). Em tal documento, a instituição, baseada na resolução CNE/CP (BRASIL, 2002), julga esta última exigência legal como "uma oportunidade (...) de se pensar conjuntamente novos rumos para a formação de professores do ensino básico e para a integração da universidade com as escolas (...) tentando se afastar do modelo predominante de profissionalização docente, onde a formação pedagógica é encarada como complementar aos conhecimentos advindos do bacharelado (p.2)".

Segundo o documento (USP, op.cit.), tal estrutura formativa, originada na década de 70 e com inspiração em orientações curriculares da década de 30, embora tenham obtido resultados satisfatórios na primeira metade do século $\mathrm{XX}$, vem encontrando dificuldades crescentes com a ampliação maciça do acesso à escola

\footnotetext{
${ }^{1} \mathrm{O}$ contexto da pesquisa em tela remete-se aos processos de estágio desenvolvidos pela Faculdade de Educação da Universidade de São Paulo, motivo pelo qual delineamos o processo de formação docente adotado nesta instituição.
} 
pública, gerando uma formação de professores com uma "distribuição de responsabilidades desarticulada (...) não se considerando a docência como uma atividade que se desenvolve dentro de um complexo contexto social e institucional (p.4)"'.

Desse modo, a Universidade de São Paulo, através da criação de comissões interdisciplinares e em ressonância com o artigo $3^{\circ}$ (inciso II) da Lei de Diretrizes e Bases da Educação Nacional (BRASIL, 1996), estabelece que seu projeto de formação de professores deve

“Ao longo de todo o processo de formação nos cursos de graduação (...) prever a indissociabilidade entre ensino, pesquisa e extensão, introduzindo os licenciandos nos processos investigativos em sua área específica e na prática docente, tornando-os profissionais capazes de promover sua formação continuada (USP, 2004, p.5)”.

Assim, a instituição defende que, durante os processos de prática relativos às diversas disciplinas de seus cursos de formação docente, o licenciando deve ter a oportunidade de ampliar e utilizar as habilidades e conhecimentos adquiridos na graduação para responder às necessidades e desafios da realidade escolar.

Explicitamente, relativo ao processo de prática denominado de estágio curricular supervisionado $^{2}$, o parecer CNP/CE (BRASIL, 2001) prevê que o mesmo deve ser entendido como

Um momento de formação profissional do formando, seja pelo exercício direto in loco, seja pela presença participativa em ambientes próprios daquela prática profissional, sob a responsabilidade de um profissional já habilitado.

Desse modo, em corroboração com a legislação vigente apresentada anteriormente, o processo de estágio, por ser parte integrante da prática docente, também deve ser visto como um momento onde o futuro professor possa refletir sobre suas atitudes no contexto experiencial específico onde atuará profissionalmente.

\footnotetext{
${ }^{2}$ Vale salientar que, segundo resolução CNE/CP (BRASIL, 2002), o termo prática de ensino como atividade curricular difere-se do sentido atribuído ao estágio curricular supervisionado. Dessa forma, a prática refere-se a atividades que se voltam para a compreensão de aspectos variados das instituições escolares e suas relações com áreas de conhecimento específico, estando inseridas nas diversas disciplinas dos cursos de graduação.
} 
Nessa linha, para a Aroeira (2009, p.29), tal processo de estágio “(...) deve ser concebido como uma prática dialética, onde exista uma relação interativa e institucionalizada entre a escola e a universidade (...) de maneira que o futuro professor seja capaz de interpretar os processos educativos, sem render-se a seus limites." Portanto, os conhecimentos teóricos devem se articular com aqueles advindos da prática, de forma que os primeiros ofereçam aos professores perspectivas de uma análise em patamares crítico-reflexivos para a compreensão dos contextos históricos, sociais, políticos e pessoais para neles intervir e, se necessários, transformá-los.

Portanto, o processo de estágio deve ir além da superação entre teoria e prática. Pimenta e Lima (2004) defendem que os conhecimentos adquiridos pelo futuro professor, ao longo do curso de formação, devem torná-lo capaz de pesquisar a realidade com olhares múltiplos, adquirindo postura e habilidade de pesquisador. Para as autoras, a reflexão, no contexto do estágio, necessita considerar que a experiência sozinha não responde às demandas da realidade, se não forem analisadas à luz das teorias da educação, pois em caso contrário,

\footnotetext{
“esta reflexão não ocorrerá, ou não poderá subsidiar mudanças (...) o processo de formação deve estimular uma perspectiva crítico-reflexiva, que possibilite criar estratégias para o exercício do pensar autônomo. Daí a importância do profissional produzir conhecimentos a partir da prática, problematizando os resultados obtidos com o suporte da teoria (p.66)".
}

Em visão convergente, Abib (op.cit.), ao defender a promoção e ampliação da autonomia do professor, expõe que os elementos centrais de modelos de uma aprendizagem docente alicerçam-se na importância do professor constituir-se como investigador de sua prática, possibilitando "um processo de interrelações estabelecidas entre os conhecimentos acadêmicos e aqueles vindos de reflexões sobre a prática pedagógica, favorecendo um controle sobre seu próprio processo de aprendizagem (p.192)”.

Desse modo, a autora destaca que as disciplinas ligadas ao estágio devem promover a evolução das ideias, das práticas de sala de aula e das atitudes necessárias ao futuro professor, visando ao desenvolvimento de um trabalho docente na direção de um ensino de Física contextualizado. Para tanto, Abib (op.cit.) explicita cinco eixos organizadores relacionados ao processo de estágio: 
a) Promover a realização de atividades que estejam organizadas em torno da resolução de problemas teórico/práticos de sala de aula, que sejam significativos (ou possam adquirir significação) para os futuros professores. Esse ponto relaciona-se ao posicionamento dos licenciandos, suas concepções sobre ensino, aprendizagem e ciência, suas práticas preliminares e, ainda, sobre seus valores e interesses.

b) Favorecer a análise dos problemas em pauta e dos possíveis encaminhamentos de soluções por meio de discussões e de instrumentos teóricos, que possibilitem conflitos e/ou lacunas, que possam promover sucessivas revisões de ideias, práticas e atitudes.

c) Promover uma aproximação com o contexto escolar e a sala de aula através da realização de práticas efetivas que ocorram o mais próximo possível das condições usuais do trabalho docente, de maneira a possibilitar sucessivas atitudes de investigação sobre suas ações.

d) Promover a realização de diversas formas de trabalho cooperativo em pequenos grupos ou com a classe e em trabalhos conjuntos com o professor ou grupo de professores da escola.

e) Contribuir para o desenvolvimento profissional na direção de uma evolução autônoma. Nesse aspecto, as reflexões coletivas em sala de aula, bem como a realização de diários de estágio contribuem para as necessárias reflexões sobre as trajetórias de aprendizagem dos futuros docentes.

Nos pontos abordados, apontamos a convergência com as idéias de Pimenta \& Lima (2004), para quem o sucesso da aprendizagem dos futuros professores passa por ambientes de colaboração e cooperação entre eles e os docentes mais experientes, supervisores do estágio, sendo necessário o feedback destes últimos, para que os formandos possam descobrir e desenvolver competências profissionais e pessoais.

Desta forma, Abib (2010) e Abib et al. (2011), em trabalhos de síntese sobre os aspectos acima abordados, estabelecem a proposta do processo de estágio investigativo supervisionado. Nessa vertente, adotada no contexto em que este trabalho se desenvolve, o estagiário, em sua prática de sala de aula, buscará atuar em duas linhas: o ensino e a pesquisa. 
Nesta perspectiva, no tocante ao viés do ensino, o licenciando buscará planejar uma sequência didática de um tema, levando-se em consideração o contexto da escola onde irá estagiar, bem como às orientações do professor colaborador ${ }^{3}$. Já em relação ao viés da pesquisa, o aluno, durante sua prática, buscará de forma exploratória responder a um problema de pesquisa significativo para ele e relacionado ao ensino de Física.

Nesta proposta de estágio, os futuros docentes, além de frequentarem as aulas relativas à disciplina do estágio no curso de graduação, realizam reuniões semanais, denominadas supervisões, onde poderão socializar com outros colegas e com o professor supervisor ${ }^{4}$, os fatos ocorridos durante a prática do estágio, bem como suas atitudes diante deles.

Dessa forma, estabelecemos nessa pesquisa, uma defesa ao enfoque críticoreflexivo no processo de estágio, buscando uma aprendizagem docente que valorize a reflexão e investigação de sua própria prática no ambiente da sala de aula, bem como nas esferas sociais e políticas. Entretanto, é fundamental tal processo de estágio respeite as necessidades e angústias inerentes ao período em que se encontra o futuro professor: a fase pré-docência.

\section{A fase pré-docência}

A fase pré-docência é caracterizada pelo período onde o futuro docente tem suas primeiras experiências no ambiente escolar, normalmente devido à realização dos processos de estágios obrigatórios exigidos para a conclusão dos cursos de licenciatura. O estágio, portanto, abre-se como um momento de possibilidade de intersecção entre os conhecimentos teóricos aprendidos nas disciplinas de graduação com a prática proporcionada na sala de aula.

Conforme exposto no tópico anterior, o estágio precisa ser entendido como um momento de aproximação da prática com a teoria, no que Pimenta e Lima (2010) denominam Estágio Curricular. Já em uma perspectiva de Estágio Investigativo, Abib (2010) salienta que a aproximação da teoria com a prática pode ser realizada na proposição de problemas relacionados ao ensino, a serem investigados pelos licenciandos, salientando que o estágio não é, somente, um momento de inserção do

\footnotetext{
${ }^{3}$ Professor pertencente ao quadro docente da escola, que acompanha as atividades de estágio.

${ }^{4}$ Monitor ou educador encarregado de coordenar e orientar o desenvolvimento dos trabalhos em pequenos grupos.
} 
futuro professor em seu ambiente de trabalho, mas também um momento em que ele pode produzir conhecimentos sobre a docência. Dessa forma, o estágio supervisionado, nesse aspecto, inclui a revisão de ideias, práticas e atitudes do licenciando, bem como testes e validações de concepções já estabelecidas quanto ao enfrentamento de conflitos originários da prática.

A questão específica sobre o enfrentamento de tais conflitos originários da prática também nos é trazida pela análise de Bejarano (2003), que considera que os "professores novatos, ao observarem a realidade de seu trabalho, apoiando-se em crenças, podem trazer conflitos ou preocupações educacionais, especialmente em contextos que afrontem estas crenças (p.2)".

$\mathrm{O}$ autor ainda explica que as crenças citadas anteriormente se originam de forma mais intensa durante o período em que o futuro professor se encontrava como aluno da educação básica, realizando uma "aprendizagem por observação (...) criando modelos de professor (p.2)".

Nesta mesma linha Fuller (1969) estabelece três categorias de preocupações educacionais por parte de professores em períodos de estágio curricular:

a) a primeira fase, identificada no início das intervenções do estagiário em sala de aula, aponta para uma inexistente ou escassa preocupação com o ensino, também chamada de fase pré-ensino.

b) a segunda fase abarca os primeiros contatos do estagiário com as preocupações de ensino, mas a preocupação centrada em si próprio ainda domina o quadro da prática docente.

c) a terceira fase já retrata uma fuga das preocupações centradas na figura do professor, dirigindo-as aos alunos e à aprendizagem.

Em uma mesma linha de pensamento, Beach \& Pearson (1998), ao analisar grupos de professores iniciantes, verificaram que professores novatos, em suas primeiras experiências docentes, ao se depararem com conflitos ${ }^{5}$ em sala de aula, adotavam dois tipos de conduta:

\footnotetext{
${ }^{5}$ No estudo citado, Beach \& Pearson (1998) também catalogaram os principais tipos de conflitos vividos por professores iniciantes, sendo a indisciplina dos alunos a principal preocupação durante os primeiros anos de docência.
} 
a) apresentaram a reação inicial de negar tais conflitos, usando de resignação, afirmando que tais conflitos não iriam mudar, independente de sua atitude.

b) assumiram os conflitos existentes, buscando soluções paliativas e de curto prazo, alterando ou não suas concepções iniciais acerca dos elementos de ensino e aprendizagem.

Em corroboração com Fuller (1969), Beach \& Pearson (1998) e Bejarano (2003), Huberman (1992) também aponta para uma excessiva preocupação do professor novato com o controle da sala de aula e preservação de sua auto-imagem. Huberman (op.cit.) ainda, ao analisar este período inicial de docência, caracteriza esta primeira etapa como um estado de sobrevivência docente, onde a principal preocupação do professor é, de fato, sobreviver ao intervalo de tempo da aula, conseguindo finalizar seu trabalho de forma emocionalmente íntegra.

Tão importante quanto esta caracterização da fase inicial de trabalho dos futuros professores, é fornecer condições de enfrentamento às situações de conflito surgidas durante o cotidiano da profissão docente, buscando modelos formativos em patamares crítico-reflexivos que possam desenvolver um profissional mais preparado para lidar com este ambiente da sala de aula, que está em constante mutação.

A seguir, buscaremos relacionar a temática até então abordada com uma das possibilidades de aprendizagem docente - os Conhecimentos Pedagógicos de Conteúdo.

\section{O Conhecimento Pedagógico de Conteúdo: conceituações e breve histórico}

A busca das habilidades docentes necessárias ao magistério permeia a literatura da área há décadas. Tardif \& Reymond (2000), por exemplo, procuraram sintetizar tais saberes ${ }^{6}$ em cinco grandes áreas, conforme ilustra a tabela a seguir:

\footnotetext{
${ }^{6}$ Os autores utilizam o termo "Saberes Docentes" para se referirem ao conjunto de conhecimentos específicos da atividade docente, que podem sofrer evoluções no decorrer da formação do professor.
} 


\begin{tabular}{|c|c|c|}
\hline \multirow{2}{*}{ SABERES } & FONTES SOCIAIS DE \\
AQUISIÇÃO & $\begin{array}{c}\text { MODOS DE INTEGRAÇÃO } \\
\text { NO TRABALHO DOCENTE }\end{array}$ \\
\hline Pessoais & $\begin{array}{c}\text { Família, ambiente de vida, } \\
\text { educação no sentido lato }\end{array}$ & $\begin{array}{c}\text { História de vida e socialização } \\
\text { primária }\end{array}$ \\
\hline Formação Anterior & Escola primária e secundária & $\begin{array}{c}\text { Formação e socialização pré- } \\
\text { profissionais }\end{array}$ \\
\hline Formação Inicial e Continuada & $\begin{array}{c}\text { Faculdade, estágios, cursos de } \\
\text { "reciclagem" }\end{array}$ & $\begin{array}{c}\text { Formação e socialização } \\
\text { profissionais nas instituições de } \\
\text { formação }\end{array}$ \\
\hline Programa e Livros Didáticos & $\begin{array}{c}\text { Nos próprios livros, programas, } \\
\text { cadernos de exercícios, fichas... }\end{array}$ & $\begin{array}{c}\text { Adaptação destas "ferramentas" } \\
\text { nas tarefas }\end{array}$ \\
\hline
\end{tabular}

Tabela 2 - Modelo Tipológico para identificar e classificar os saberes dos professores - adap. de Tardif \& Reymond (2000).

A análise da tabela nos mostra que, desta forma, o docente, apresenta uma complexa gama de situações e contextos que podem contribuir com sua identidade profissional, e, consequentemente, com a produção de saberes que serão utilizadas em sua prática.

Além dos conhecimentos adquiridos em sua formação inicial ou continuada, não se pode deixar de citar o próprio ambiente escolar onde o professor trabalha ou trabalhou, local propício para o desenvolvimento docente mediante a socialização profissional com seus pares e sua prática em sala de aula, bem como a necessária adaptação de livros e programas didáticos neste ambiente específico.

Tão importante quanto o contexto escolar e a formação acadêmica do docente, vale salientar que o perfil profissional do professor pode sofrer influência de períodos prédocência, quando ainda não se encontrava em efetivo exercício docente. A imersão em práticas de vida pré-profissional, tais como sua formação familiar e escolar básica, podem influenciar sua identidade no magistério.

Nesta linha de pensamento, Lee Shulman, ao pesquisar as habilidades docentes referidas anteriormente, expõe pela primeira vez, em uma conferência realizada na Universidade de Texas, em 1983 (“The Missing paradigm in research on teaching”), o 
conceito que seria, mais de três décadas depois, um dos principais temas de estudo da pesquisa em formação de professores - O Conhecimento Pedagógico de Conteúdo $\left(\mathrm{CPC}\right.$ ou $\left.\mathrm{PCK}^{7}\right)$.

Tomando como base a definição conferida por Lee Shulman em seu primeiro trabalho acerca do tema (1987), o saber pedagógico de conteúdo ou conhecimento pedagogizado do conteúdo, como preferem tratar alguns autores (QUEIRÓZ, 2001, por exemplo), relaciona-se com um específico conjunto de conhecimentos, aptidões e técnicas necessárias ao exercício da profissão docente. Para Magnusson et al (1999)

O PCK é uma compreensão do professor de como ajudar os estudantes a entender um tópico específico da matéria. Isso inclui conhecimentos particulares do tópico, problemas e como eles podem ser organizados, representados e adaptados aos diversos interesses e habilidades dos aprendizes (...) o PCK é como uma transformação do conhecimento para outros domínios." (p.96)

De acordo com Moraes (2010, p.68), Shulman, destaca o papel basilar da experiência como componente fundamental na construção de saberes constituintes de uma profissão. Shulman afirmava ainda, que seria necessário construir um arsenal de repertórios experienciais, vivências, casos, erros e acertos denominado artifact of scholarship, que propiciaria aos professores iniciantes o aprendizado a partir da prática de outros professores, mais experientes.

Em síntese, esta primeira versão de PCK estabelecida por Shulman é definida como:

“[O PCK] é (...) como um caminho de conhecimento que é único para professores no que diz respeito ao conteúdo e sua transformação em instrução para que os alunos possam compreender (...) é a categoria mais provável para distinguir o entendimento do conteúdo de um especialista quando comparado com um professor.” (SHULMAN, 1987, p.8)

Shulman (op. cit.), ao iniciar os estudos sobre os saberes necessários ao professor enquanto profissional, desenvolveu o que ele chamou de conhecimentos de base (knowledge-base):

\footnotetext{
${ }^{7}$ Pedagocical Content Knowledge.
} 
Se o conhecimento docente fosse organizado em um manual, uma enciclopédia, ou alguma outra forma (...), como seriam as categorias? (p.8)

Na tentativa de responder a esta questão, o autor propõe a inclusão, mínima, dos seguintes conhecimentos:

a) Conhecimento do conteúdo, enfatizando não apenas a disciplina escolar em si, mas seus aspectos filosóficos e históricos.

b) Conhecimentos pedagógicos gerais, com especial ênfase aos princípios e métodos de gestão de salas de aula;

c) Conhecimento do currículo; enfatizando-se, aqui, a compreensão dos programas da disciplina ministrada;

d) Conhecimento pedagógico de conteúdo, como um amálgama entre a pedagogia e o conteúdo, exclusiva da função docente, revela a forma própria, única e especial do entendimento profissional;

e) Conhecimento dos estudantes e suas características;

f) Conhecimento dos contextos educacionais (sala de aula, finanças, governo, comunidade escolar);

g) Conhecimento dos objetivos educacionais, suas propostas, valores e suas evoluções históricas e filosóficas.

Segundo Shulman (op.cit.), a passagem do conhecimento disciplinar para o seu respectivo conhecimento de ensino, ocorre através do processo denominado Raciocínio Pedagógico, o qual reúne processos complexos e reflexivos, inerentes às ações educativas, retratando como os conhecimentos são acionados, relacionados e construídos durante o processo de ensinar e aprender, sendo dividido em seis grandes momentos:

a) Compreensão: relaciona-se a identificar os propósitos e estrutura do conteúdo, produzindo uma compreensão especializada da disciplina de conhecimento, que permite ao professor criar condições para que a maioria de seus alunos aprenda;

b) Transformação: envolve a combinação de quatro subprocessos que juntos, são capazes de produzir um conjunto de estratégias para uma aula, unidade ou curso: 
b1) preparação: interpretação e análise crítica de textos, criação de repertório curricular e exposição dos objetivos.

b2) representação: uso de exemplos, analogias, metáforas ou demonstrações.

b3) seleção: escolha das melhores estratégias de ensino.

b4) delineamento das características discentes: consideração de concepções espontâneas, dificuldades, contexto cultural, motivação, interesses, classe social e capacidade de aprendizagem dos alunos.

Em um aspecto geral, o próprio autor coloca que o processo de transformação envolve, portanto, o planejamento, análise do currículo e do conteúdo proposto, selecionando as melhores estratégias e metodologias de ensino conhecidas, levando em consideração as especificidades dos alunos, visando promover melhorias nos processos de ensino/aprendizagem. A questão discente, em particular, é tratada por Shulman (op.cit., p.15) quando o autor destaca a importância de se utilizar as características dos alunos, considerando não apenas o cognitivo, mas também o afetivo como fator de motivação, interesse, auto-conceito e atenção.

c) Instrução ou Formas de Ensino: referem-se ao desempenho observável do professor, envolvendo organização e gestão de classe, formas de lidar com os alunos individualmente e em grupos, dosagem de conteúdos, coordenação das atividades de aprendizagem, explicações, questionamentos, humor, discussões, disciplina, ensino por descoberta ou investigação, entre outros.

d) Avaliação: processos de feedback que ocorrem no decorrer e após a instrução.

e) Reflexão: relaciona o conjunto de processos reflexivos que envolvem a revisão e a análise crítica do desempenho do professor sobre sua ação pedagógica.

f) Novas Compreensões ou Metacognição: uma compreensão do conjunto do processo, levando em consideração os aspectos docentes, discentes, bases de conhecimento, dentre outros, que possibilitariam uma compreensão mais enriquecida e consolidada sobre os processos de ensino e aprendizagem.

De posse destas etapas elaboradas por Shulman (1987), Moraes (op.cit.) estabelece um quadro esquemático, onde são incorporados os momentos necessários à elaboração 
do conhecimento pedagógico de conteúdo por parte do professor, que será adaptado a seguir: 


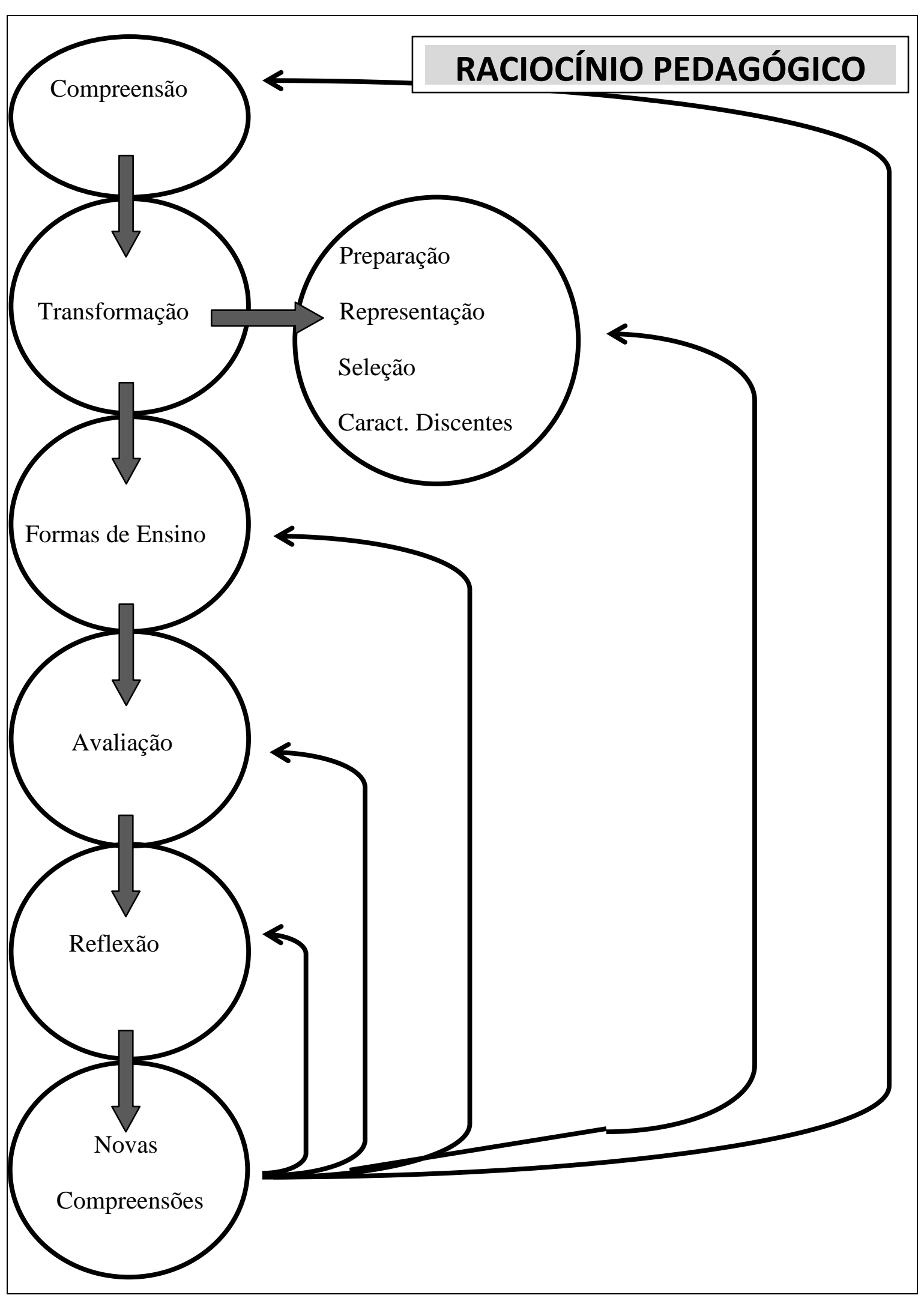

Fig.3 - Modelo do Raciocínio Pedagógico na elaboração do PCK, adap. Moraes (2010, p.71) 
O quadro anterior busca delinear, de acordo com nossa visão do processo de elaboração do PCK, como o professor, mediante processos reflexivos e metacognitivos coerentes, pode identificar em que fase o desenvolvimento disciplinar pedagógico apresenta falhas ou lacunas, sendo possível o retorno a este ponto e conseqüente reelaboração dos saberes envolvidos.

Nesta primeira fase, Lee Shulman procura centrar seu conceito de Conhecimento Pedagógico de Conteúdo em um patamar muito mais cognitivo e individual, localizando-o, principalmente, nos saberes provenientes da própria experiência docente na sala de aula ou escola, citando, porém, a influência que a formação inicial e continuada também traria a esta construção. "O PCK, portanto, parece aliar a experiência do professor com o conteúdo específico. De fato, vários estudos evidenciam que o PCK é adquirido, principalmente, pela própria experiência na docência (...) ao considerar que a prática tem um grande valor no conhecimento profissional” (SALES, 2010, p.23).

A importância da experiência tornou-se um fator tão crucial enquanto elemento docente necessário ao bom trabalho no magistério que HERNANDEZ (1992), a eleva como pedra fundamental, criando as categorias de "professor-perito" e "professorprincipiante.

"O professor-perito " é aquele que mostra uma eficácia superior durante um período de tempo maior; apresenta um elevado rendimento pedagógico em função da experiência adquirida, e que se verifica na forma como resolve os problemas que lhe são colocados durante a atividade. "O perito mostra maior nível de adaptação e controla melhor as emoções em comparação com o professor principiante". (p.111)

No início da década de 90, Shulman (de acordo com GARRITZ, 2010, p.15) procura trazer alguns esclarecimentos acerca de seus trabalhos iniciais, relatando que foi mal interpretado quanto à utilização de alguns termos: Os conhecimentos de base, por exemplo que distinguiriam o magistério como profissão, inclui aspectos de racionalidade técnica, porém envolve, também, capacidades de julgamento, improvisação e intuição, “o que Schön chamou de reflexão na ação". Além disso, Shulman também busca esclarecer que o processo de ação e raciocínio pedagógico 
ocorre em contextos particulares, o que geraria interações espontâneas e improvisadas, sendo um "predicado inevitável ao sucesso do ensino" (p.12).

$\mathrm{Na}$ tentativa de repensar seu primeiro modelo de PCK, Shulman trouxe críticas ao seu próprio modelo (SHULMAN \& SHULMAN, 2004), nas quais destaca a pouca ênfase no nível da ação, posicionamento excessivo do individual como unidade de análise, esquecendo-se da comunidade dos professores, além de não se considerar o afeto, motivação ou paixão; Shulman, nesta análise crítica, ainda discorre sobre a necessidade de se ter um ponto inicial que não seja apenas o conhecimento de conteúdo.

\footnotetext{
"Em estudos anteriores sobre a aprendizagem docente (...) desenvolvemos estudos que eram estritamente cognitivos e individuais, como o PCK(...) estas concepções não eram suficientes para dar conta do que nós estávamos encontrando(...) reconhecemos a necessidade de abarcar uma concepção mais compreensiva da aprendizagem docente, dentro das comunidades e contexto." (p.1 - tradução nossa)
}

Nesta vertente, Shulman \& Shulman (op. cit.) estabelecem a importância de se considerar as "comunidades de aprendizagem docente", afinal, o professor é membro de uma comunidade profissional que está posta, sendo capaz de ensinar e aprender através de suas próprias experiências. Com base nesta proposta, são incorporados cinco novos elementos no auxílio à aquisição de melhores conhecimentos profissionais por parte do docente:

a) A Visão: O professor deve estar pronto para ensinar, o que segundo o autor, implica no mesmo ter a visão articulada e um alto desenvolvimento que alavanquem sua prática contra um status de insatisfação anterior;

b) A Motivação: O contexto onde o docente encontra-se inserido deve ser capaz de motivá-lo a desenvolver novas visões de ensino;

c) A Compreensão: O professor deve compreender o que está sendo pesquisado em sua área de ensino, bem como a forma de ensinar. Nesta categoria, os autores incluem os conhecimentos disciplinares e interdisciplinares, o currículo, o PCK propriamente dito, a gestão da sala de aula, além do 
acompanhamento da comunidade em suas perspectivas intelectual, social, cultural e pessoal;

d) A Prática: Segundo os autores, não basta o professor estar motivado, se ele não apresenta habilidades para alterar sua prática. A complexidade atual do ensino faz necessária a aprendizagem destas adaptações;

e) A Reflexão: O processo de reflexão crítica é o "coração da aprendizagem docente" (p.4). O professor deve ter a capacidade de aprender com a experiência e, portanto, conseguir propor mudanças através de processos metacognitivos.

No esquema a seguir, Shulman procura efetuar as relações entre os processos citados acima e as funções da comunidade docente e política onde o professor está inserido, relações estas que influenciarão no estabelecimento e desenvolvimento do Conhecimento Pedagógico de Conteúdo em determinado contexto.

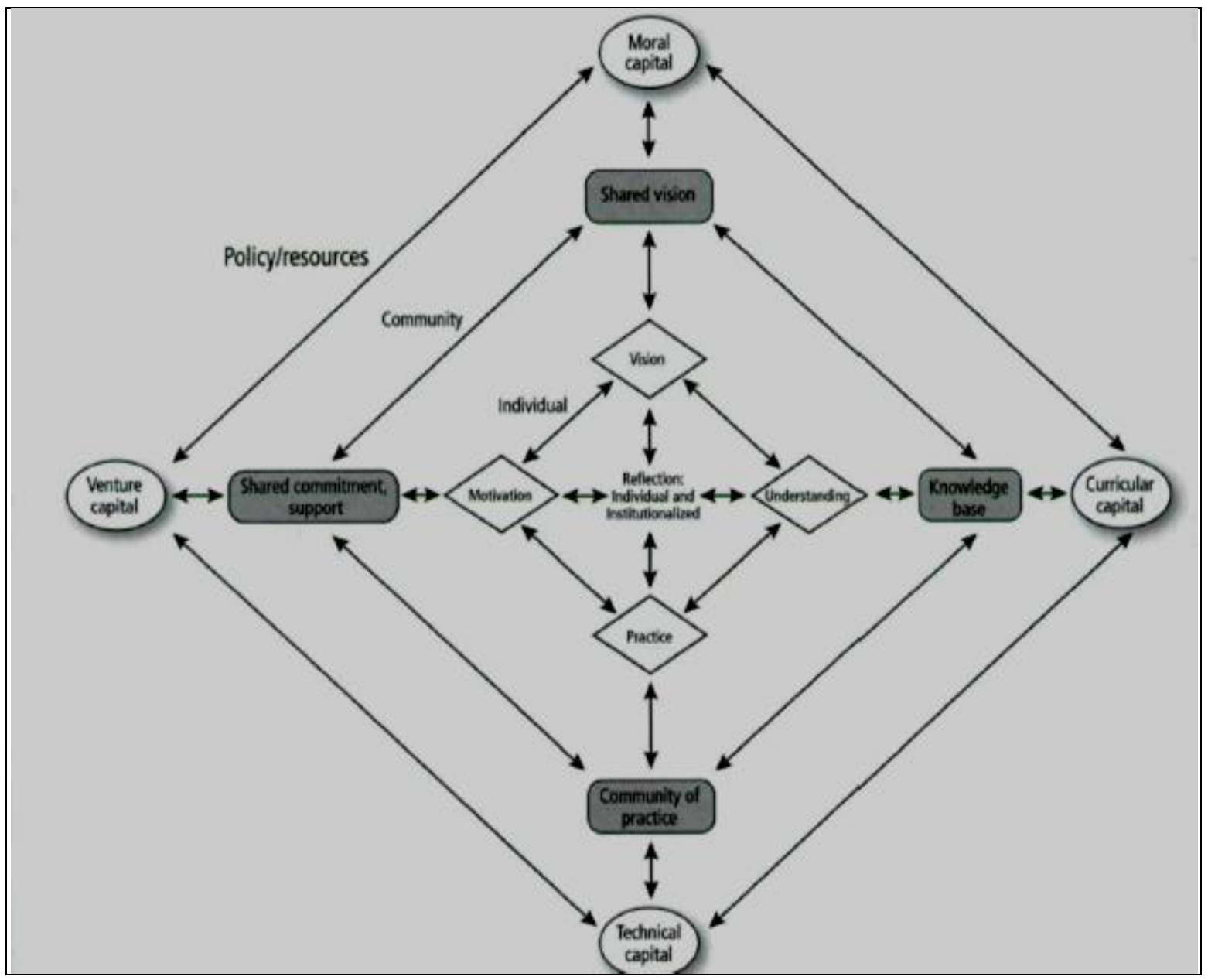

Fig. 4 - Níveis individual, comunitário e político do desenvolvimento docente. (Extraído de Shulman \& Shulman (2004)). 
Em síntese, Shulman, nesta nova visão de PCK, estabelece que, na expectativa de desenvolvimento do Conhecimento Pedagógico de Conteúdo, o professor deverá atuar em um patamar reflexivo de sua prática, repensando constantemente sua prática através de mediações de sua comunidade de aprendizagem (sala de aula, escola, diretorias de ensino,...), sendo que, para isso deverá: a) compreender a matéria a ser ensinada de forma profunda, flexível e genérica; b) compreender os princípios pedagógicos, sendo capaz de implementar e planejar intervenções consistentes com elas; c) reconhecer implementações incompletas ou com pouco significado para a aprendizagem; d) considerar as variações nas aprendizagens dos alunos.

De acordo com Ponte \& Chapman (2006), estudos recentes envolvendo o PCK demonstram este esforço em estabelecer uma perspectiva crítica e contextualizada através da reformulação ou complementação com outras noções teóricas. Os autores citam, por exemplo as pesquisas de Rossouw e Smith (1998), Even e Markovitz (1991) e Klein e Tirosh (1997) que relataram estudos sobre os conhecimentos pedagógicos de conteúdo elementares de professores do ensino médio americano, discutindo a necessidade de alargar a noção de PCK de Shulman. Nestas pesquisas, apesar dos professores terem tido acesso aos mesmos cursos e ambientes de desenvolvimento, constatou-se que os PCK produzidos por eles apresentavam diferenças consideráveis, sendo uma característica intrínseca docente.

Desta forma, em corroboração com o novo modelo de PCK proposto por Shulman, o olhar puramente cognitivo dado aos trabalhos sobre o desenvolvimento de saberes docentes vem dando espaço aos contextos profissionais, escolares, culturais e sociais mais amplos.

Nesta linha de aprimoramento do primeiro modelo de PCK estabelecido por Shulman, em 1987, não se pode deixar de salientar o intenso movimento surgido na literatura específica, criando alternativas teóricas a este quadro. Nas últimas décadas, diversos trabalhos foram publicados considerando um ambiente mais amplo para o desenvolvimento do Conhecimento Pedagógico de Conteúdo. Grossmann (1990), em seu entendimento acerca do PCK, divide-o em quatro grandes categorias: o conhecimento de conteúdo, o conhecimento pedagógico geral, o conhecimento das propostas e programas de ensino conforme já estabelecido por Shulman, inserindo, entretanto, o conhecimento do contexto como forte influência na formação docente. Em sua proposta, Grossmann enfatiza a necessidade do professor estar sempre em relação 
com propósitos do ensino de um determinado nível em diferentes etapas da escolaridade, conhecer as concepções espontâneas dos alunos sobre o tema, os materiais curriculares disponíveis para o ensino daquele conteúdo, bem como as estratégias de ensino e articulações disciplinares e interdisciplinares.

Em 1993, Cochran, na linha construtivista, separa o PCK em quatro componentes: pedagógica, conteúdo a ser ensinado, características dos estudantes e, mais uma vez, o contexto ambiental da aprendizagem ${ }^{8}$. O autor enfatiza em sua pesquisa que "para se possuir um bom Conteúdo Pedagógico de Conteúdo, é necessário ter um bom conhecimento de conteúdo, não sendo, entretanto, um fator suficiente" (p.710). Esta questão do saber aprofundado com relação aos conteúdos de referência das ciências de referência da disciplina que se ensina voltaria mais de 15 anos depois com Ball (2008) e Baumert (2010), quando, por exemplo, o primeiro afirma que "professores devem saber o conteúdo que ensinam. Professores que não sabem bem o conteúdo para eles mesmos não terão condições suficientes para ajudar seus estudantes a compreendêlo (p.404)". Cochran também aponta para o fato de que professores sem experiência apresentariam níveis de PCK menos completos, pois suas conexões entre o conteúdo e o pedagógico ficariam mais claras, sofisticadas e complexas com o passar do tempo, no exercício da prática do ensino. Devido a este fato, Cochran utiliza o termo PCKg (Pedagogical Content Kwowing), em uma alusão à sua visão da dinâmica do conhecimento docente, que estaria em constante crescimento.

Gess-Newsome (1999), apresenta uma discussão entre dois modelos representativos da evolução dos conhecimentos docentes: uma proposta integrativa, onde o PCK é o resultado intersectivo dos conhecimentos disciplinares, pedagógicos e de conteúdo, os quais, após evoluções independentes, unem-se na formação do perfil final do saber pedagógico de conteúdo; e uma proposta transformativa, onde os conhecimentos citados anteriormente se combinam e se transformam em PCK durante a prática docente, conforme esquema a seguir:

\footnotetext{
${ }^{8}$ Nota-se que, novamente, o contexto de aprendizagem é citado como um forte influenciador da formação docente, fator este que, até então (1993), não havia sido pontuado de forma incisiva na proposta inicial de Shulman.
} 

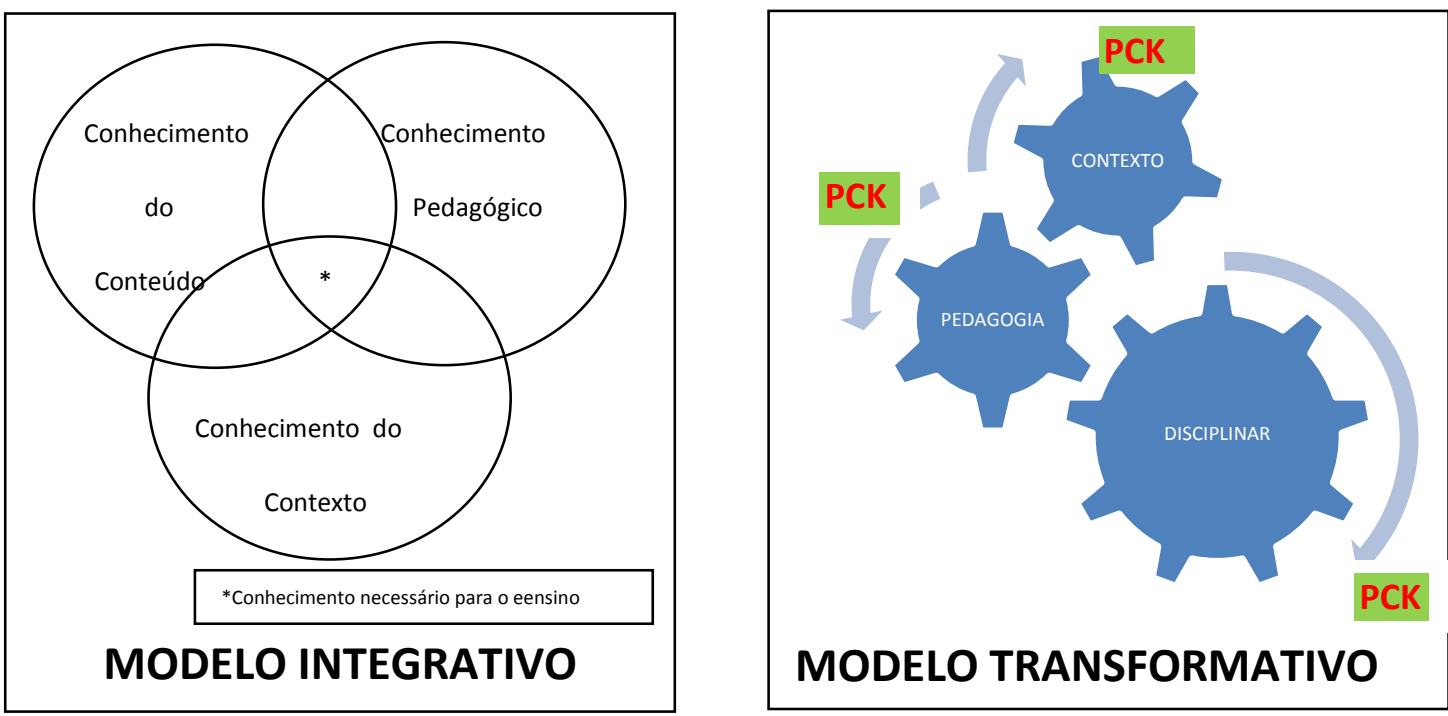

Fig. 5 - Adaptação dos Modelos Integrativo e Transformativo propostos por Gess-Newsome (1999).

Em suma, o modelo integrativo proposto por Gess-Newsome considera o Conhecimento Pedagógico de Conteúdo como uma resultante entre os conhecimentos de conteúdo $(\mathrm{CC})$, pedagógicos $(\mathrm{CP})$ e contexto $(\mathrm{CCx})$, relacionando-se como uma mistura, o que faz com que o PCK criado seja considerado um novo conhecimento, mas uma articulação de seus componentes. Já o modelo transformativo sugere uma transformação entre os conhecimentos citados, sendo que o PCK criado é considerado como um novo produto, obtido da interação entre os componentes. Em uma analogia científica, o modelo integrativo poderia ser considerado como um fenômeno físico, onde poderá ocorrer interação entre as partículas, porém sem modificar suas estruturas. O modelo transformativo, entretanto, aproximar-se-ia de um fenômeno químico, onde, após a interação entre os componentes, ocorre mudança de estrutura dos mesmos, formando uma nova substância.

Nesta linha de pensamento, a autora propõe que o modelo transformativo se apresentaria como um conhecimento de base sintetizado para o ensino, ajudando a compreensão dos estudantes para tópicos específicos e, sendo usado, pelo docente, apenas no ambiente de sala de aula. Ainda segundo Gess-Newsome (1999), “esse conhecimento advém de generalizações de episódios de ensino que causaram dificuldades ao professor (p.12)", sendo, portanto, a sala de aula, a locação primária deste tipo de conhecimento docente.

Gess-Newsome (op.cit.) ainda salienta que o suporte dado ao modelo transformativo dos Conhecimentos Pedagógicos de Conteúdo é encontrado na necessidade do professor, em sua prática, de recorrer à "aplicações de soluções 
imediatas para os problemas do ensino (p.15)", devendo-se ter o cuidado de não concentrar a formação docente unicamente neste modelo, devido ao risco de transformála em uma "sacola de dicas (p.15)". Segundo a autora,

“ um bom professor tem Conhecimentos Pedagógicos de Conteúdo Transformativos bem formados para todos os tópicos mais comumente tratados no ambiente da sala de aula (p.12)'”.

Já no caso do modelo integrativo, o objetivo do professor seria, prioritariamente, selecionar os conhecimentos de base independentes e integrá-los para criar efetivas oportunidades de aprendizagem. Para a autora,

“um bom professor, então, é aquele que tem seus conhecimentos de base bem organizados (...) que são facilmente acessados e podem ser flexibilizados durante o ato de ensino (GESS-NEWSOME, 1999, p.11.).

A título de síntese, Gess-Newsome (1999, p.14), propõe uma tabela comparativa entre os modelos integrativo e transformativo dos Conhecimentos Pedagógicos de Conteúdo, estabelecendo quatro grandes grupos de análise - os domínios do conhecimento, as habilidades docentes necessárias, a questão da formação docente e as implicações da utilização de cada um desses modelos, conforme exposto a seguir. 


\begin{tabular}{|c|c|c|}
\hline & $\begin{array}{l}\text { MODELO } \\
\text { INTEGRATIVO }\end{array}$ & $\begin{array}{l}\text { MODELO } \\
\text { TRANSFORMATIVO }\end{array}$ \\
\hline Domínio do Conhecimento & $\begin{array}{l}\text { Conhecimento do Conteúdo, } \\
\text { Pedagógico e do Contexto } \\
\text { desenvolvem-se } \\
\text { separadamente e são } \\
\text { integrados no ato de ensino. } \\
\text { Cada Conhecimento de Base } \\
\text { deve ser bem estruturado e } \\
\text { facilmente acessível. }\end{array}$ & $\begin{array}{l}\text { Conhecimentos do Conteúdo, } \\
\text { Pedagógico e Contexto, } \\
\text { desenvolvidos separadamente } \\
\text { ou não, são transformados em } \\
\text { PCK, um conhecimento usado } \\
\text { para o ensino. O PCK deve ser } \\
\text { bem estruturado e facilmente } \\
\text { acessível. }\end{array}$ \\
\hline Habilidades Docentes & $\begin{array}{l}\text { Os professores, facilmente, } \\
\text { ativam a integração do } \\
\text { conhecimento de base para } \\
\text { cada tópico pensado. }\end{array}$ & $\begin{array}{l}\text { Os professores possuem PCK } \\
\text { para todos os tópicos pensados. }\end{array}$ \\
\hline Formação Docente & $\begin{array}{l}\text { Os Conhecimentos de base } \\
\text { podem ser pensados } \\
\text { separadamente ou integrados. } \\
\text { Habilidades de integração } \\
\text { devem ser incentivadas. } \\
\text { Experiências de ensino e } \\
\text { reflexões reforçam o } \\
\text { desenvolvimento, seleção, } \\
\text { integração e o uso dos } \\
\text { conhecimentos de base }\end{array}$ & $\begin{array}{l}\text { Os Conhecimentos de base são } \\
\text { pensados já unidos. A } \\
\text { experiência docente reforça o } \\
\text { desenvolvimento, seleção e } \\
\text { utilização do PCK. }\end{array}$ \\
\hline Implicações & $\begin{array}{l}\text { Identificação com a } \\
\text { formação docente. } \\
\text { Como a transferência e } \\
\text { integração dos } \\
\text { conhecimentos podem ser } \\
\text { incentivados? }\end{array}$ & $\begin{array}{l}\text { Identificar exemplos de PCK e } \\
\text { suas condições de uso. } \\
\text { Como esses exemplos e } \\
\text { critérios de seleção podem ser } \\
\text { melhor pensados? }\end{array}$ \\
\hline
\end{tabular}

Tabela 3 - Modelos Integrativo e Transformativo do PCK (traduzido a partir de Gess-Newsome (1999, p.14)). 
Já Abell (2007), elaborou uma própria concepção de PCK em ensino de ciências, onde o conhecimento pedagógico do conteúdo é o resultado não linear de inferências diversas dos contextos onde o professor está inserido. $\mathrm{O}$ quadro abaixo busca delinear esta relação entre os saberes docentes e o ambiente onde está introduzida sua prática.

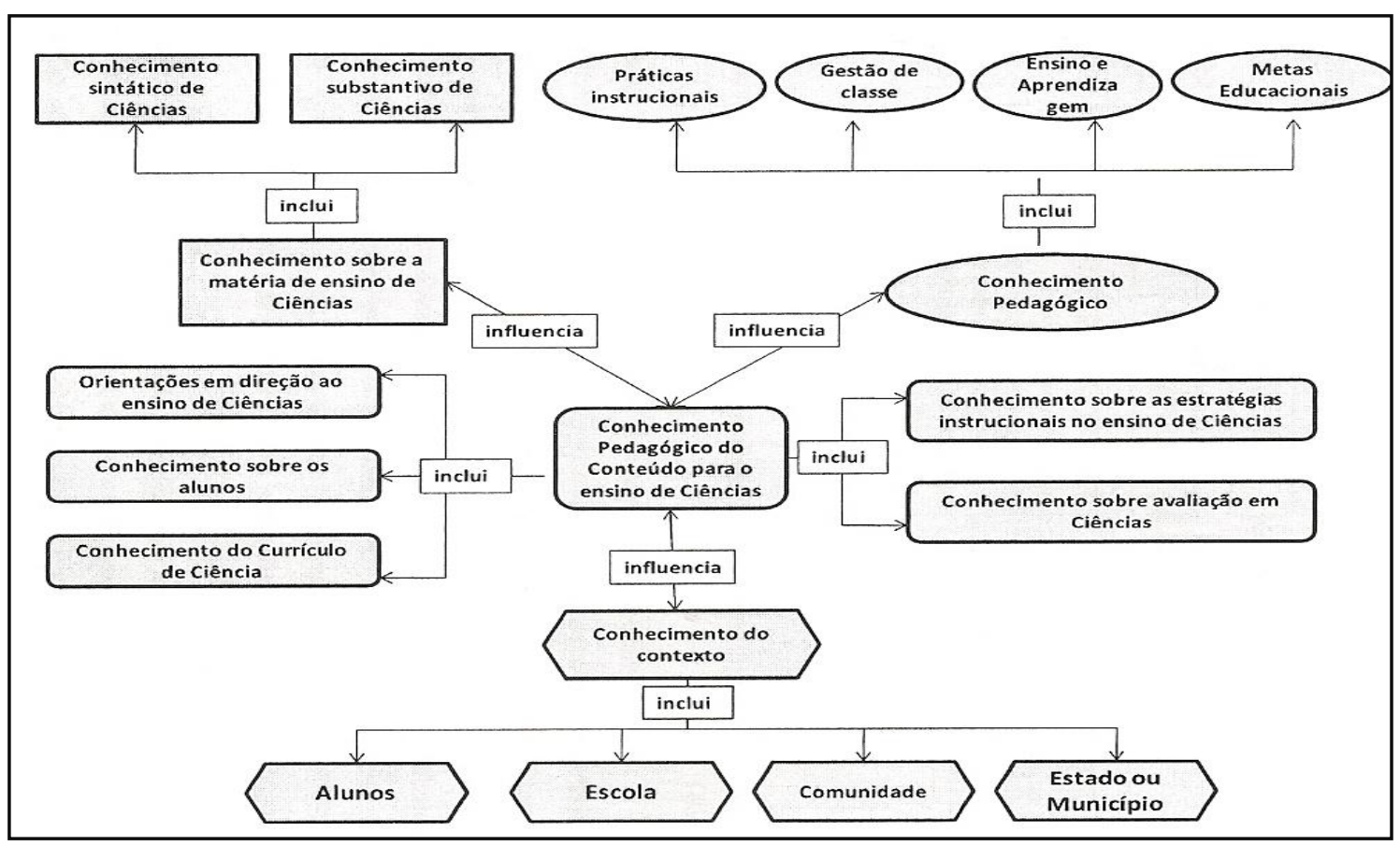

Fig. 6 - Rede contextual envolvida na elaboração do PCK (extraído de Abell (2007))

O modelo proposto acima procura ressaltar a complexidade da rede de influências na qual o professor encontra-se sujeito. Este conjunto de fatores, conforme já reforçado por SHULMAN \& SHULMAN (2004), apresentam forte influência na formação do PCK docente. Conforme salienta o próprio precursor do Conhecimento Pedagógico de Conteúdo, “ (...) as pessoas constroem as organizações e estas, constroem as pessoas." (SHULMAN E SHULMAN, op. cit.).

Ainda em 2007, Dijk \& Kattmann, propõe uma proposta de PCK iniciada na fusão do currículo escolar americano e a didática alemã, culminando com o programa internacional chamado ERTE (Educational Reconstruction for Teacher Education). Em síntese, o programa citado assemelha-se muito a proposta de Shulman \& Shulman (2004), onde o ambiente onde ocorrerá a aprendizagem (tanto docente, como discente) é de fundamental importância, podendo influenciar na análise do conteúdo e estudos empíricos acerca das concepções dos estudantes, fatores estes que contribuiriam para o estudo do Conhecimento Pedagógico de Conteúdo docente. 
Bozkurt et al (2008) realizou pesquisas sobre o desenvolvimento do Conhecimento Pedagógico de Conteúdo que professores turcos de ciências apresentavam a respeito da camada de ozônio, concluindo, estatisticamente, que a maioria dos professores possuíam níveis bons ou razoáveis acerca do conteúdo científico abordado, porém, praticamente não apresentavam conhecimentos sobre a estratégias de ensino, aprendizagem ou dificuldades dos alunos sobre o tema.

Ainda em 2008, Ball et al, ao estudar os PCK de professores de matemática dos níveis fundamental e médio nos EUA, buscaram um refinamento ainda maior do modelo apresentado por Shulman \& Shulman (2004), estabelecendo duas novas categorias no estudo do Conhecimento Docente, estabelecendo o Conhecimento Horizontal de Conteúdo, existente nas situações em que o professor utiliza o programa ou currículo de séries futuras para preparar ou escolher o conteúdo e a forma de sua abordagem para o estudante da série atual e o Conhecimento Especializado de Conteúdo $\left(S C K^{9}\right)$, que diz respeito a peculiaridades existentes no ensino de determinados tópicos dentro de uma disciplina, sendo necessárias estratégias específicas em sua condução. No caso da pesquisa de Ball et al, este conhecimento foi constatado quando do ensino específico de frações a uma turma que já havia sendo trabalhada com o ensino geral sobre o conceito de número.

No término da primeira década do século XXI, Kind (2009) em trabalho de revisão crítica da literatura produzida na área do Conhecimento Pedagógico de Conteúdo, verificou a existência de nove modelos criados até então. Para a autora, o principal questionamento a ser realizado era se os PCK eram advindos de conhecimentos separados ou combinados, remetendo às categorias integrativas e transformativas, respectivamente, já elaboradas por Gess-Newsome (1999). Em sua análise, foi constatado que apenas três modelos propostos (entre eles, Shulman e Cochran) poderiam ser classificados na esfera transformativa. Vale ressaltar que Kind (op.cit.), ao realizar esta revisão da área, volta a enfatizar a relação entre os modelos citados.

(...) em um modelo integrativo, o PCK é o conhecimento que o professor tem e usa em sala de aula, onde o conhecimento de conteúdo $(S M K)^{10}$ é uma parte [do PCK]. No modelo transformativo, o PCK é um novo conhecimento

\footnotetext{
${ }^{9}$ Specialized Content Knowledge.

${ }^{10}$ Subject Matter Knowledge
} 
que nasce do ato da transformação do conhecimento de conteúdo em propostas de ensino a estudantes. (p.182)

Adaptando a analogia já realizada por Gess-Newsome (1999), Kind (2009) enfatiza que, o PCK transformativo é como um composto químico formado pelo rearranjo de componentes previamente existentes, que não serão separados facilmente, ou seja, "o conhecimento de conteúdo é um componente separado que é alterado na criação do PCK (p.181)”.

Em sua análise, Kind ainda reforça que, no âmbito da formação docente, é extremamente necessário que os licenciandos tenham domínio de um bom conhecimento de conteúdo, afinal, "[os licenciandos] não nascem com o PCK (...) nos cursos de formação inicial adquirem um banco de habilidades e novos conhecimentos que muitas vezes não são relacionados em contextos coerentes (p.186)”. Desta forma, a autora expõe 3 fatores reincidentes nos estudos da área que contribuiriam para o desenvolvimento profissional docente: a) ter um bom conhecimento de conteúdo - um bom SMK é um pré-requisito para o desenvolvimento docente, pois uma boa base teórica da disciplina específica facilitaria possíveis mudanças necessárias ao andamento da aula; b) a experiência em sala de aula é crucial - segundo Kind (op. cit.) estudos apontam que mudanças significativas ocorrem nos primeiros meses e anos da profissão. "No caso particular de professores de ciências, a percepção de ciência se altera consideravelmente, partindo da ciência aprendida em alto nível nos bancos universitários até sua percepção da disciplina como interpretada em contextos escolares (p.187)". c) atributos emocionais fazem parte de um desenvolvimento profissional por parte do professor - a autora enfatiza que boa dose de auto-confiança e condição emocional de suportar o ambiente de trabalho escolar são essenciais para professores iniciantes e experientes. Neste item específico, Kind volta a enfatizar os benefícios de um bom Conhecimento de Conteúdo, pois este conferiria uma sensação de segurança ao docente, contribuindo para o desenvolvimento de um PCK apropriado. Segundo a autora (p.191), sem bons SMK, os professores tendem a ser mais passivos e adeptos de estratégias de caráter instrucional, demonstrando menos conhecimentos no momento de intervir em dificuldades dos alunos.

À guisa de conclusão, Kind (2009), particularmente no caso dos professores de ciências, defende a utilização de modelos transformativos na formação inicial destes docentes, pois este "focaria nos problemas de um conhecimento de conteúdo específico 
em seu ensino, discutindo estratégias mais precisas e deixando este fato explícito (p.192)". Segundo a autora, os modelos integrativos são mais utilizados, pois tendem a oferecer um quadro mais geral das habilidades e conhecimentos dos professores,

"[os modelos integrativos estão refletindo a prática de sala de aula na formação dos professores(...) cursos de formação inicial, frequentemente, apresentam uma enorme gama de componentes e, normalmente, não indicam como os licenciandos os combinariam em um contexto coerente, mas deixam isso ocorrer naturalmente durante a experiência em sala de aula (p.198)"

Neste contexto, o estudos propostos por Kind sugerem a adoção de modelos puramente integrativos pode resultar em licenciandos que não conseguem se desvencilhar de modelos de ensino calcados na pura transmissão de informações, utilizando conhecimentos já definidos pelos manuais de ensino. Em contraponto, os modelos transformativos seriam mais úteis no ensino de ciências, pois ofereceriam uma base teórica mais abrangente aos licenciandos quando do ensino de tópicos científicos.

Apesar desta visão de Kind (2009), aparentemente dicotômica entre os modelos transformativos e integrativos de Conhecimentos Pedagógicos de Conteúdo, Salazar (2005) expõe a importância de considerar estas vertentes como extremos de um contínuo, onde o patamar puramente integrativo representaria um marco do conhecimento onde os saberes disciplinares, pedagógicos e do contexto se desenvolvem em separado e são integrados no cotidiano docente. Já em uma instância transformativa, ocorreria a concentração no desenvolvimento destes saberes em Conhecimentos Pedagógicos de Conteúdo. Em corroboração com Kind (2009), a autora também aponta que “(...) o caráter científico da pedagogia clama por processos transformadores na formação docente (...) que permitam professores capazes de refletir e compreender as relações das intenções educativas com o conteúdo e o contexto (p.16)."

A questão da reflexão docente em sua formação volta a ser tratada, mais recentemente, por Marcon et al (2011), ao estudar o paralelismo entre o conhecimento pedagógico de conteúdo e o processo de raciocínio pedagógico, expõe a necessidade de expor o docente, principalmente durante sua formação inicial, a situações-problema, que, em uma linha construtivista de análise, desencadeariam insatisfações com práticas didáticas não apropriadas, o que provocaria a busca por um novo equilíbrio. Segundo o autor: 
“(...) ao ser confrontado com dilemas e situaçõesproblema, o PCK desencadeia uma sequência de tarefas que, em conjunto com diferentes momentos de reflexão, encaminha tanto ao alcance dos objetos da prática pedagógica quanto à aprendizagem dos alunos (p.263)".

Segundo esta proposta, sem a existência das situações desafiadoras e problemáticas, o professor sem o PCK "não saberia por onde começar e nem traçaria seus objetivos na prática pedagógica (p.263)". Portanto, para que o futuro professor possa refletir de maneira consciente e objetiva, é preciso a criação de uma base sólida de conhecimentos provida de diferentes fontes e instâncias, como por exemplo “ o conhecimento dos alunos, do conteúdo, pedagógico geral, contexto educacional e do próprio $\mathrm{CPC}^{11}$ (MARCON, op. cit, p.269)".

Nesta visão, é preciso que as estratégias implementadas com o futuro professor necessitem ser elaboradas de maneira a atingir a maior parte de dimensões possível do PCK, impondo-lhe problemas, dilemas e desafios o mais próximos daqueles encontrados na realidade do trabalho docente durante o processo de ensino $\mathrm{e}$ aprendizagem.

Ressalta-se que, nesta pesquisa, o conhecimento pedagógico de conteúdo é abordado como um conhecimento que busca fazer a ponte entre o conhecimento específico de conteúdo e a prática docente, possibilitando a formação de um conjunto complexo de estratégias, habilidades e conhecimentos que, aliados às variáveis do contexto específico onde está inserido o professor, bem como às características intrínsecas de seus processos reflexivos e criativos, permitem a elaboração de um saber mais refinado e fundamentado, específico para aquela situação.

\section{O Ato Criativo Inovador e o Conhecimento Pedagógico de Conteúdo}

O processo de criação é uma característica peculiar do ser humano (VIGOTSKY, 2009 e Piaget, 1974), ocorrendo frequentemente no decorrer do nosso cotidiano. $\mathrm{O}$ ato criativo, compreendido como uma nova elaboração necessária mediante eventos inesperados permeia, mesmo que inconscientemente, o ambiente escolar e, mais

\footnotetext{
${ }^{11}$ Conhecimento Pedagógico de Conteúdo (sigla correspondente em português para o PCK).
} 
ainda, a profissão docente, onde cria-se e recria-se constantemente com o objetivo de inserir novas estratégias na prática de sala de aula e suas ramificações no ambiente dinâmico do magistério. Segundo Bicudo (2005, p.27), “a criatividade é necessariamente libertária do ponto de vista da produção de conhecimento".

As novas situações com que o docente depara-se no exercício de sua função exigem que este profissional esteja preparado para este enfrentamento, ou seja, é preciso que o professor seja capaz de refletir sobre as ocorrências inéditas que permeiam seu dia-a-dia. Como estabelece Contreras (2002), torna-se fundamental que este docente tenha autonomia e capacidade para resolver criativamente os novos problemas que surgem durante sua prática, procurando inserir interações inovadoras no processo de ensino e aprendizagem. Estabelece-se, desta forma, a necessidade da formação de docentes no patamar crítico-reflexivo, visando uma maior emancipação do professor e de sua visão de ensino, nunca deixando de lado a reflexão, fundamental para a tomada de consciência acerca dos fatos inerentes ao seu trabalho.

Nessa linha, um dos primeiros ambientes viáveis à construção dessa autonomia docente é o processo de estágio, momento em que o futuro professor apresentará contato com o contexto real de sua atuação, emergindo situações de conflitos e lacunas (Abib, 2002) que possibilitam discussões e aprofundamentos para suas soluções. Diante deste quadro, salientamos, novamente, a importância da prática docente, durante sua formação inicial ser pautada em uma visão reflexiva, procurando o desenvolvimento de um profissional preparado para criar diante os imprevistos de sua profissão, com uma prática autônoma.

Ainda nesta vertente, fica evidente que, na elaboração do Conhecimento Pedagógico de Conteúdo, dentro da perspectiva do Raciocínio Pedagógico (RP) proposto por Shulman (1987), exige-se que o professor envolvido no processo apresente o mesmo patamar reflexivo citado anteriormente, afinal estamos tratando de um docente que, mediante processos reflexivos sobre sua prática, ocorridos em etapas específicas do Raciocínio Pedagógico, tem a capacidade de efetuar retornos aos pontos lacunares de sua elaboração, buscando promover reelaborações com maior grau emancipatório.

Em estudos referidos em autores anteriores (Rossouw, Smith, Even, Markovitz, Klein, Tirosh, Escudero e Sánchez, por exemplo), constatou-se, reiteradamente que, mesmo em professores que, supostamente, se encontravam em ambientes contextuais com variáveis controladas acerca da elaboração de seu Conhecimento Pedagógico de 
Conteúdo, os PCK surgidos apresentavam consideráveis diferenças, o que demonstraria que o processo, em si, não apresenta uma linearidade tão grande como o proposto, originalmente por Shulman, sendo uma característica intrínseca de cada professor.

Nos estudos de Even \& Markovitz (1991), por exemplo, verificou-se que professores de matemática de ensino fundamental, orientados a trabalhar o tópico de funções de $1^{\circ}$ grau da mesma forma específica, apresentavam diferentes olhares no tocante às dificuldades dos alunos, gerando diferentes níveis de aprendizagem discentes. Já Klein \& Tirosh (1997) concluíram que o contexto da experiência docente é relevante para a aprendizagem dos alunos - ao estudarem professores de matemática novatos e experientes ao ensinarem os conceitos de multiplicação e divisão, notaram que o último grupo consegue estabelecer melhor situações-problema que instigavam os estudantes. Rossouw \& Smith (1998) e Escudero \& Sanchez (1999), em estudos com professores de Geometria do ensino médio, já propunham um alargamentoda visão do PCK proposto inicialmente por Shulman, sendo necessária a inclusão do contexto de aprendizagem como fator fundamental para o estudo da formação docente.

Nesta linha de pensamento, estabelecemos a hipótese de que, como o contexto da elaboração do PCK encontrava-se fixado, a provável etapa onde este controle não poderia ser tão expressivo se encontraria no processo de Transformação do Raciocínio Pedagógico, onde o docente, de fato, efetuaria $e$ "contemplaria as formas mais úteis de representação, analogia, ilustrações, exemplos, explicações e demonstrações mais poderosas de um determinado tópico (SHULMAN, 1987)”. Nesta etapa, a estrutura proposta (preparação $=>$ representação $\Rightarrow$ seleção $\Rightarrow$ características dos alunos) estabelece que o professor, neste momento, deve:

Planejar, analisar o currículo e o conteúdo proposto, selecionar as melhores estratégias e metodologias de ensino conhecidas, levando em conta as especificidades dos alunos. (MORAES, 2009, p.70).

Apesar de uma aparente linearidade desta etapa, é neste momento que o professor se depara com a necessidade de autonomia para, simplesmente, criar, criar uma interação inovadora ou, em face do contexto e/ou de sua formação, adaptar interações já existentes.

Salienta-se, portanto, que a etapa de transformação é um ponto fundamental do processo de elaboração de um Conhecimento Pedagógico de Conteúdo, porém, 
propomos neste trabalho a hipótese de que o conjunto de micro-processos responsáveis por esta evolução é de alta complexidade, invadindo o desenvolvimento cognitivo do professor, mais precisamente, seu processo interno de criação, não podendo, portanto, ser resumido a uma sequência imutável e geral, mas a uma série de desencadeamentos psíquicos particulares relacionáveis ao contexto social onde está inserido o docente.

Também salientamos que, nessa investigação, não focaremos em um único modelo de Conhecimento Pedagógico de Conteúdo, conforme os descritos até então. Nossa opção, por procurar abarcar os aspectos criativos envolvidos na elaboração de tal conhecimento, nos leva a optar por um modelo próprio, que será tratado no capítulo referente à análise dos resultados, procurando, dessa forma, utilizar o PCK como um instrumento dessa análise, possibilitando a identificação dos processos criativos docentes. No próximo capítulo, procuramos discutir as bases cognitivas e culturais para a caracterização destes processos. 
CAPÍTUlO III

O ATO CRIATIVO 
Até o presente momento, este trabalho, baseado na premissa discutida anteriormente, de que a criatividade é uma característica inerente ao trabalho docente em uma perspectiva reflexiva-crítica, neste capítulo, procuraremos abordar os processos inerentes ao ato de criação humano, procurando descrever e analisar as etapas do processo criativo necessárias para que o indivíduo consiga inserir, de forma inovadora, um novo elemento em seu cotidiano e, mais especificamente, um docente consiga efetuar novas intervenções em sua prática.

Para tanto, buscaremos alicerçar as descrições nas teorias sócio-históricoculturais, mais especificamente nas noções de consciência e atividade exposta na psicologia vigotskiana, procurando, assim, contemplar o aspecto de desenvolvimento psíquico-social na elaboração criativa. No tocante ao enfoque cognitivo interno, em particular às operações mais complexas envolvidas no desenvolvimento de estruturas e reflexões mentais existentes durante a criação, optou-se por complementar nossa discussão com a teoria de equilibração piagetiana, a qual, a nosso ver, possibilita um maior aprofundamento neste tópico em particular, contribuindo para futura análise dos dados obtidos na pesquisa.

Tal necessidade de articulação entre estas teorias, aparentemente incompatíveis, vem da análise da literatura específica, corroborada por Braga (1995, p.147) e Vasconcelos (2001), onde a criação é considerada um processo exclusivamente humano, e, para tanto, apresenta a coexistência de fatores biológicos e culturais, que interagem e medeiam este tipo de ação.

Especificamente, segundo a primeira autora, o cérebro humano é um órgão que nasce com muitas possibilidades, pois tem uma organização fisiológica que favorece a criação de novas e múltiplas conexões entre os neurônios, as quais não aumentam exclusivamente devido a fatores biológicos, mas também com através de sua relação com o ambiente.

Por outro lado, o ambiente humano é cultural, o que implica que o comportamento humano, e sua criação, consequentemente, são relacionados a uma rede de valores, hábitos, crenças, atitudes particulares de cada cultura, o que acarreta padrões comportamentais e criativos relativos ao meio social. Neste sentido, a autora (p.148) expõe que: 
A relação entre os fatores culturais e biológicos do pensamento é bastante complexa, e é justamente daí que emerge a criação, da confluência desses dois fatores - de mentes e culturas em constante transformação.

Nesta linha de interpretação, Stoltz (1999) ressalta que diversos autores (Kneller, Guilford, Torrance, Wallach, por exemplo) já tratavam o desenvolvimento criativo como uma reestruturação dos processos mentais internos, porém não podendo se esquecer do papel central que o grupo de referência cultural tem nesta etapa. Para De la Torre (1996):

A criatividade é uma capacidade pessoal, porém, somos frutos da interação sociocultural(...) é a sociedade que sanciona e reconhece como criativas nossas ideias ou realizações.

Desta forma, o autor expõe a necessidade de tomarmos um eixo sociocognitivo para o estudo da criatividade, ou seja, a ênfase deve ser dada nos componentes cognitivos e sócio-culturais.

Com base no exposto anteriormente, em nossa visão, as teorias piagetiana e vigotskiana, respectivamente, procuram, através de suas específicas metodologias, abordar o aspecto criativo através de um patamar biológico e sociocultural, vertentes, estas, complementares em relação à criação humana, especificamente. Ao término do capítulo, procuramos esboçar possíveis divergências e convergências entre as teorias acima citadas, haja vista serem tradicionalmente consideradas como opostas e incompatíveis, justificando a articulação complementar de aspectos da mesma na criação de um arcabouço teórico para o estudo da criatividade.

\section{O Ato Criativo Inovador na Psicologia Piagetiana}

A base histórico-cultural, em particular aquela referida nos trabalhos vigotskianos contribuem claramente para uma possível explanação dos processos envolvidos na elaboração de um ato criativo inovador por parte do indivíduo (e do docente, especificamente). Entretanto, em nosso ponto de vista, corroborado por diversos estudos, como os já realizados por Emilia Ferreiro, José Castorina, Marta Kohl e Ricardo Basquero, por exemplo, o processo de internalização, fundamental na teoria de Vigotsky, compreendido como uma reorganização individual do indivíduo sujeito às 
ferramentas culturais, ou nas palavras de Vigoysky (1989), a reconstrução interna (intrapessoal) de uma operação externa (interpessoal), demonstra-se insuficiente para uma análise mais profunda dos processos mentais de cognição e reflexão, os quais são fundamentais e enriqueceriam um estudo mais profundo do complexo sistema criativo. Conforme nos expõe Castorina (2008):

A noção de internalização coloca-nos em um plano interessante para examinar as dificuldades enfrentadas pela teoria vigotskiana (...)não se trata de questionar a generalidade ou mesmo as limitações da caracterização do processo de internalização, porque isso significaria exigir uma precisão na reconstrução cognitiva que não chegou a ser tratada por Vigotsky. (p.31, grifo nosso)

De fato, segundo o próprio Vigotsky (1989), “ a internalização das atividades socialmente enraizadas e historicamente desenvolvidas constitui o aspecto característico da psicologia humana (...) até agora, conhece-se apenas um esboço desse processo (p.65, grifo nosso).

Diante deste quadro, especificamente no tocante à elaboração de propostas pedagógicas criativas, optamos em utilizar a teoria de equilibração desenvolvida por Piaget em sua psicologia genética no sentido de articular a questão biológica da criação humana, procurando, desta forma, a geração de um maior apoio teórico na interpretação dos resultados obtidos no trabalho de campo. Apesar de serem considerados autores tradicionalmente dicotômicos (cf. Castorina \& Barquero, 2008, por exemplo), a análise mais detalhada das obras de Piaget e Vigotsky nos remete a uma possível compatibilidade, dependente dos problemas e interações tratadas, conforme exporemos no tópico 4 deste capítulo.

$\mathrm{Na}$ análise do conjunto de obras de autoria de Jean Piaget, o tema "criatividade", em sentido estrito, parece dar o ar de sua presença apenas em uma palestra proferida pelo autor, na Universidade de Paris em 1972 (Vasconcelos, 2001). $\mathrm{Na}$ ocasião, Piaget expõe algumas deliberações acerca do processo criativo, sintetizadas a seguir:

- a criatividade desenvolve-se de acordo com o esforço do indivíduo, não apresentando relações hereditárias ou com precocidade. Desta forma, o 
processo criativo não é considerado algo inato, e sim o resultado de sucessivos desenvolvimentos ocorridos durante a vida;

- a criatividade dos processos é diretamente proporcional à extensa leitura do indivíduo, dentro e fora de sua área, ou seja, a quantidade de informações adquiridas pelo indivíduo refletem no aumento das possibilidades criativas do mesmo;

- o desenvolvimento da inteligência é uma criação contínua - cada estágio produz algo radicalmente novo(...) a construção do sujeito enriquece os objetos externos, assimilando esta dimensão.

Diante da insuficiência de relatos piagetianos com referência direta ao desenvolvimento criativo, buscaremos na psicologia genética ${ }^{12}$, desenvolvida pelo autor, adaptações de suas teorias que nos possam favorecer a criação de um "referencial com viés cognitivo" para o estudo dos processos criativos. Parece-nos muito coerente que a criação humana passa pelo lidar com a novidade, para transformá-la e, consequentemente, obter o desenvolvimento de algo inédito. Tal linha de pensamento corrobora com o modelo epistemológico genético proposto pelo autor genebrino.

Nessa linha de estudo, Piaget (1968), estabeleceu o desenvolvimento da intelectualidade em estágios bem definidos, os quais apresentavam características e períodos próprios ${ }^{13}$. Salienta-se, porém que, apesar da divisão aparentemente estática dos estágios cognitivos, Piaget (1968, p.139) afirma que a integração das estruturas

\footnotetext{
${ }^{12}$ Segundo Piaget (1968), a psicologia [da criança] estuda [ a criança em seu ] desenvolvimento mental. “(...) convém, neste sentido, distingui-la da psicologia genética (...) para dissipar todo e qualquer equívoco na terminologia (...) refere-se ao desenvolvimento intelectual individual (ontogenia) (...) explicar as funções mentais pelo seu modo de formação e desenvolvimento." (p.9).

13 Desta forma, de forma sintética, as principais especificidades dos níveis cognitivos apontados pelo autor são: nível Sensório-Motor, englobando os indivíduos até 2 anos de idade,aproximadamente, que, na falta da função simbólica, ainda não apresentam pensamento, nem afetividade ligada a representações que permitam evocar pessoas ou objetos na ausência destes. Nesta etapa ocorre a elaboração de subestruturas cognitivas que servirão de ponto de partida para suas construções perceptivas e intelectuais. Após o desenvolvimento das funções simbólicas, ocorre a evolução para condutas posteriores; nível das Operações Concretas, com o desenvolvimento dos esquemas sensório-motores e da função simbólica, permite-se uma interiorização direta e rápida das ações em "operações", tais como a conservação de substância, peso e volume; e o nível das Operações Formais, perfazendo a faixa etária entre 12 e 15 anos, caracterizando-se pela libertação do concreto e inserção do mundo real em um conjunto de transformações possíveis, mediante o manejo de hipóteses e raciocínios abstratos.
} 
sucessivas permite esta divisão (...), onde a ordem de sucessão é constante, embora as idades médias que a caracterizam possam variar de um indivíduo para outro, conforme o grau de inteligência ou meio social (grifo nosso). Desta forma, pode-se constatar que a teoria Piagetiana não busca debruçar-se, exclusivamente nos processos cognitivos, destacando, também, as interações sociais entre o sujeito e o meio, que medeiem sua relação com o objeto, sendo que este tema ainda será abordado com maior profundidade no decorrer deste capítulo.

A passagem entre os níveis cognitivos citados, dar-se-ia, segundo Jean Piaget, através de sua Teoria de Equilibração. Neste ponto, vale ressaltar que, este modelo autoregulativo foi desenvolvido, inicialmente, para a análise do desenvolvimento epistemológico do sujeito, não tendo raízes iniciais com o campo pedagógico. Conforme expõe Silva (1995):

(...) as ideias de Piaget e seus colaboradores influenciaram diretamente o ensino, mas tratam do sujeito epistêmico e não propriamente do aluno que se encontra na sala de aula(...) os trabalhos que tentaram fazer avançar a aplicabilidade das ideias de Piaget para a sala de aula implicam na substituição do sujeito epistêmico pelo sujeito psicológico (p.111)”.

O próprio Piaget (1969) esclarece que:

(...) há décadas, sob o nome de "pedagogia experimental", foi constituida uma disciplina especializada no estudo de tais problemas [educacionais]. A pedagogia experimental ocupa-se apenas do desenvolvimento e dos resultados de processos propriamente pedagógicos (...) os problemas levantados são outros e referem-se menos aos caracteres gerais e espontâneos (...) que a sua modificação pelo processo em questão (p.91)",.

Ainda nesta linha de pensamento, Lerner (2008), aponta que as posturas didáticas aplicacionistas, que convertem o desenvolvimento das estruturas intelectuais ou funcionamento cognitivo em objetivos e conteúdos da educação, têm sido criticadas reiteradamente a partir do próprio seio da concepção piagetiana, tanto porque desvirtuam o sentido das pesquisas psicogenéticas quanto porque desconhecem a natureza da instituição escolar. Ainda segundo Lerner (op. cit, p.95), ao deduzir os objetivos educacionais da psicologia, esquecemo-nos que a escola está inserida em uma sociedade e que as finalidades da educação só podem emanar da realidade social. 
Conforme já exposto em Testoni (2004), a teoria de equilibração piagetiana pressupõe uma interação entre o sujeito e o objeto, que poderá permitir um desenvolvimento intelectual mediante uma série de fatores que fazem os dados de percepção sofrerem contínuas elaborações no nível cognitivo. De acordo com a proposta, o conhecimento restabelece-se cada vez em níveis mais evoluídos face à existência de um objeto (compreendido neste trabalho, como físico ou social, conforme já citado) que, através de processos de reequilibração, criam patamares mais estáveis de pensamento. Para Piaget (2002), conhecer o objeto é agir sobre ele, modificá-lo, transformá-lo e compreender o processo desta transformação. Apesar de o modelo piagetiano estabelecer esta ação direta sobre o objeto, tal procedimento não implica, necessariamente, em uma ação isolada do indivíduo.

Neste patamar construtivista, portanto, as propostas de ensino destacam (e, assim, não eliminam) o papel do professor como um agente apto a estabelecer um clima de cooperação entre os integrantes, para que se possa ocorrer uma livre exposição e crítica das ideias apresentadas. Ainda na questão da cooperação, Mortimer \& Carvalho (1996) apontam que, durante este tipo de relação social, está prevista uma descentralização e socialização do conhecimento, conseguindo, desta forma, uma construção racional e dinâmica do mesmo.

A estrutura teórica da equilibração fornece uma formatação segundo a qual, o indivíduo possui um sistema cognitivo que se encontra em equilíbrio dinâmico, ou seja, uma estabilidade relativa, um progresso para estágios de conhecimento mais evoluídos. Tal sistema funciona através de um processo de adaptação, ou seja, o resultado de uma aproximação do sujeito com o objeto de conhecimento.

A adaptação ocorre de duas formas distintas e complementares: a primeira delas, a assimilação, visa a uma incorporação de um elemento exterior no esquema conceitual do indivíduo e, a acomodação, ou seja, um processo que resulta, segundo Silva (op. cit.), da necessidade em que se acha a assimilação de levar em conta as particularidades próprias dos elementos a assimilar. Em suma, a assimilação ocorreria quando algo novo é incorporado dentro de um sistema cognitivo/explicativo já formado. Já a acomodação, é gerada por uma perturbação do sistema, onde, a relação sujeito-objeto produziu mudanças nas explicações, reconstruindo o esquema já existente, visando a um patamar mais elevado. 
Apesar de um caráter aparentemente linear e unilateral nas ideias citadas, ressalta-se que este processo se vale de um ajustamento progressivo e complementar entre assimilação e acomodação. Desta forma, um sujeito, ao reestruturar um fato novo em um sistema já criado, é obrigado a alterar em parte as explicações que já possuía, para que assim, estas últimas passem a dar conta das novas possibilidades (assimilação). Por outro lado, se o indivíduo muda as suas explicações em virtude de um novo acontecimento, esta mudança ocorrerá até o limite suficiente para adquirir novamente uma estabilidade em seu sistema cognitivo (acomodação).

A retirada da estabilidade do sistema cognitivo (conflitos, contradições ou perturbações) talvez seja um dos mais importantes aspectos do trabalho piagetiano, tendo em vista esta ser a fonte dos progressos no desenvolvimento do conhecimento. São nestas perturbações que o indivíduo é obrigado a ultrapassar um estado de menor conhecimento e tentar ampliá-lo em busca de novos horizontes explicativos. Os desequilíbrios podem ser desencadeados por duas grandes classes de perturbações:

- Conflitos: neste caso existe uma incompatibilidade entre as ideias propostas pelo meio externo e as existentes no cognitivo do indivíduo. Neste caso, tem-se a resistência pelo objeto, obstáculos à assimilação recíproca do fato. Nesta situação poderá ocorrer uma acomodação do sistema cognitivo do sujeito ao novo conhecimento, ou então uma compensação, que são ações agindo em sentido contrário a determinado efeito, tendendo a anulá-lo ou neutralizá-lo.

- Lacunas: podem ser entendidas como a insuficiência de esquemas conceituais para a compreensão do fenômeno em questão. Para Silva (1995), a lacuna se torna uma perturbação quando se trata da ausência de um objeto ou das condições de uma situação que seriam necessárias para concluir uma ação, ou ainda, a carência de um conhecimento que seria indispensável para resolver um problema.

Durante a interação sujeito e objeto, ocorre a transformação do primeiro pelo segundo e vice-versa, resultando em um processo que poderá ser compreendido, portanto, como a construção do conhecimento. Este último, por sua vez, encontra-se correlacionado a um fator básico dentro da teoria piagetiana: o conceito de equilibração 
majorante. Por este processo pode-se entender o fato do ser humano estar, inevitavelmente, condicionado a elaborar e construir concepções sempre mais elaboradas quando interage com a realidade. Quando se assimila ou acomoda algo, se produz um avanço, pois possíveis dados são construídos ou equilibrados no sistema cognitivo.

Em sua teoria, Piaget (1976), distingue três tipos de condutas no que se refere às relações entre as modificações e as compensações ocorridas no sistema cognitivo do sujeito. A primeira delas é o comportamento alfa, onde o indivíduo tentará neutralizar a perturbação, não lhe atribuindo importância. Esta fase é parcialmente compensadora e o equilíbrio será facilmente perturbado. Dessa forma, o autor estabelece duas possibilidades de reação do sujeito,

Se a perturbação é fraca, a compensação será obtida por uma simples modificação introduzida pelo sujeito no sentido inverso da perturbação (...) mas, se a perturbação for mais forte ou julgada como tal pelo sujeito, ele a anulará, simplesmente afastando-a ou negligenciando-a (PIAGET, 1976, p.64)

Já o comportamento beta, não ignora a perturbação, mas cria teorias para explicá-la. Ocorrerá a tentativa de incorporar o elemento perturbador ao sistema cognitivo na forma de compensação, mas mais com o objetivo de anulá-lo. Segundo Piaget (op.cit.),

(...) a integração no sistema do fato perturbador, modifica o sistema (sic) por deslocamento de equilíbrio, até tornar assimilável o fato inesperado. Dessa forma, uma explicação casual refutada por um fato imprevisto será completada ou substituída por outra, levando-se em conta o novo fator (...) a perturbação é eliminada como perturbação (p.66).

A última das três condutas, o comportamento gama, utiliza a reorganização iniciada em beta para modificar o sistema, eliminando a perturbação e inserindo-a nos modelos criados, tratando-a como mais uma possibilidade. Denominada por Piaget como "conduta do tipo superior", em tal comportamento, o sentido da compensação é o de uma simetria inerente à organização do sistema, e não mais uma eliminação das perturbações. Segundo o autor, 
[na conduta gama] ocorre uma antecipação de todas as transformações possíveis (...) [ocorre] uma compensação completa e o fechamento da estrutura elimina qualquer contradição (p.66).

Portanto, com o objetivo de sintetizar estes principais pontos da Teoria de Equilibração piagetiana, quando um sujeito interage com um objeto, podem ocorrer dois processos: assimilação ou acomodação. No primeiro, o sistema cognitivo é capaz de explicar e agregar o fato ocorrido, no segundo há um processo de perturbação, provocado por um lacuna ou conflito, que pode gerar uma reorganização da estrutura conceitual inicial. No caso da lacuna, também tratada por Piaget como uma forma de perturbação,o sistema não possui elementos suficientes para a explicação do fato, já no caso do conflito, o obstáculo se coloca diretamente em oposição ao sistema cognitivo, atingindo-o estruturalmente. Nas duas situações, o indivíduo iniciará a fase de compensação, na qual poderá negar total ou parcialmente ou acontecido, ignorando-o, ou tentando acomodá-lo no esquema conceitual.

Em pesquisas recentes apontadas (Vasconcelos, 2001), infere-se que o sistema neural e o desenvolvimento neurológico, consequentemente, estão interligados ao processo de adaptação conforme sugerido por Piaget, encontrando-se nesta fase, movimentações necessárias à construção de imagens mentais, o que nos permite consignar acerca da íntima relação do sistema de conexões neuronais com a ação da criança na realidade. Ainda nesta linha, Rourke (1993) apud Vasconcelos (op. cit.) aponta que meios que oferecem melhores condições de ação à criança, levam ao estabelecimento de novas conexões nervosas, mediante análise de ondas elétricas corticais e musculares produzidas.

Diante da estrutura proposta pelos processos autorregulativos piagetianos, mais precisamente dentro do referencial da equilibração, propomos utilizar este enfoque no estudo do processo criativo, afinal, os postulados epistemológicos de Piaget podem ser adaptados sem prejuízo para este trabalho com o fato do "lidar com o novo", fazendo com que partamos da hipótese de que conhecimento e criatividade são essencialmente construção (...) o processo criativo surge da dinâmica do desequilíbrio contínuo, que através da tensão e da regulação, nos levam a criar (VASCONCELOS, 2001, grifo nosso). 
Entretanto, segundo o próprio Piaget (em palestra proferida em 1972 citada por VASCONCELOS, op. cit.), além dos processos equilibrantes de sua teoria que dariam conta da criação da novidade, todos os atos de criatividade intelectual vêm do processo de abstração reflexiva, o qual se encontraria incorporado à estrutura de equilibração. Durante o processo de abstração reflexiva, o sujeito, além de assimilar ou acomodar a interação com o objeto, efetuaria uma reconstrução em um plano cognitivo superior, ocasionando uma tomada de consciência e conhecimento da ação como um todo, gerando, desta forma, a criação da novidade. Ainda para Vasconcelos (op. cit.), Piaget enfatiza o desenvolvimento contínuo da imaginação para o desenvolvimento do processo criativo inovador, salientando o seu início a partir dos dois anos de idade, com o início da função simbólica na criança:

A imaginação permite o brincar e, é neste brincar que a criança expande o imaginário e a criatividade (...) a reversibilidade revoluciona as estruturas e permite grande expansão da criatividade no sentido de equilibrar aspectos imaginários em fantasia com abstrações reflexivas da realidade. (JUSTO, 2001, p.34)

Salienta-se, portanto que, na imaginação está o espaço para o movimento criativo, sendo o "brincar" um espaço privilegiado para sua expansão. Neste momento, o brinquedo criaria um estado de tensão criativa, sendo uma grande fonte de desenvolvimento da criação humana.

Em termos de referencial teórico, ressalta-se que "[em Piaget] a metáfora do desenvolvimento da lógica natural como hierarquia escalonada de sistemas estruturais(...) não foi feliz (CASTORINA \& BAQUERO, 2008)”. Realmente, esta suposta linearização das estruturas cognitivas e suas transformações geraram inúmeras críticas ao trabalho piagetiano, o que fez com que ele repensasse seus preceitos no final de sua obra, onde, ainda segundo os autores, " o contexto das condições socioculturais e os diferentes domínios de conhecimento (...) começou a se insinuar no final da obra piagetiana, como em a Psicogênese e História da Ciência, de 1981 (p.41)”.

Apesar disto, não se pode afirmar, como fazem diversos críticos, que Piaget negou-se desde o início à aceitação da questão social no desenvolvimento mental. Em sua obra Psicologia da Criança (1968), podemos notar que: 
A evolução dos esquemas depende da maturação dos sistemas nervoso e endócrino, do papel do exercício e da experiência adquirida na ação efetuada sobre os objetos (...) o terceiro fator fundamental, insuficiente por si só, é o das interações e transmissões sociais(...) a socialização é uma estruturação, para a qual o indivíduo contribui tanto quanto dela recebe. Por outro lado, mesmo na transmissão escolar, a ação social é ineficaz sem uma assimilação ativa (p.142).

Em Piaget (1974), apesar da consideração da questão social, o autor atentava para a carência, até então, de conhecimentos especializados quanto à construção dos saberes historicamente constituídos:

(...) que embora tenhamos começado a conhecer os níveis de formação das operações lógico-matemáticas ou da causalidade (...) não dispomos ou ainda não dispomos de conhecimentos comparáveis quanto aos mecanismos constitutivos que geram as estruturas lingüísticas ou que dominam a compreensão dos fatos históricos (p.94).

Corroborando com esta tese, Lerner (2008) identifica que a prioridade atribuída à interação social por Piaget pode ser constatada em sua recorrente atitude de pregar o trabalho em grupo na escola. Piaget assumia, efetivamente, que a cooperação entre as crianças é tão importante para o progresso do conhecimento como a ação dos adultos; a permissão de um verdadeiro intercâmbio de pontos de vista, são insubstituíveis como meio de incentivar a formação do espírito crítico e de um pensamento cada vez mais objetivo.

Em suma, o conhecimento didático não pode ser deduzido diretamente das contribuições epistemológicas de Piaget. Ao estudar a situação didática, é preciso levar em consideração, além da natureza do processo cognitivo envolvido, a natureza e características do saber a ser comunicado e da ação exercida pelo professor para garantir esta comunicação, cumprindo, consequentemente, uma função social a ele atribuída.

Apesar das insistentes citações piagetianas ao meio social, não podemos deixar de salientar que tais inferências não configuram uma teoria própria de análise do papel social do ser humano, em caráter mais amplo e cultural, conforme exposto, por 
exemplo, nas teorias sócio-histórico-culturais imersas na psicologia vigotskiana. A seguir procuramos iniciar o estabelecimento da relação entre estes modelos, iniciando com as noções peculiares de atividade e consciência desta última teoria.

\section{O Ato Criativo na Psicologia Vigotskiana}

Através do referencial piagetiano exposto anteriormente, buscamos um delineamento da vertente biológica associada à criação humana, ou seja, as formas encontradas pelo indivíduo para reequilibrar suas estruturas mentais quando da ocasião de eventos novos, o que exige a transformação destes últimos pelo sujeito, favorecendo a criação de novos esquemas.

Entretanto, de acordo com Braga (1995), a criatividade é ao mesmo tempo, biológica e social, o que nos remete às limitações dos estudos de Piaget neste último aspecto, considerando o termo "social" em um caráter mais amplo, envolvendo a sociedade e a cultura, portanto.

Para a análise do contexto sociocultural onde o docente encontra-se inserido, é necessário, portanto, a inserção de alicerces teóricos que cubram este conjunto de fatores também inerentes ao ato criativo, os quais, a nosso ver, são coerentes com as visões sócio-histórico-culturais.

\section{1. $\quad$ Consciência e Atividade}

De acordo com RIGON (2009), a teoria sócio-histórico-cultural tem seu início em 2001, quando a chamada escola Vigotskiana tem as teses de seus autores (Vigotsky, Luria, Leontiev e Bolhovich, por exemplo) sistematizadas e aperfeiçoadas. Baseada no materialismo histórico-dialético proposto por Karl Marx, esta linha de pensamento sustenta-se, segundo RIGON (op. cit.) em três princípios básicos:

a) a manifestação da vida social, política e espiritual do homem aparece sempre condicionada pela produção material;

b) pelo trabalho, o homem faz história e cultura, ou seja, produz-se a si mesmo; é um ser histórico; 
c) as transformações da realidade se dão de forma dialética, ou seja, provocam superações qualitativas.

Ainda segundo este autor, baseado nestas premissas, o ser humano, desde o nascimento, está em constante aperfeiçoamento psíquico, passando por:

- operações de comportamento inatas hereditárias, o que, em no senso comum, chamamos de instintos;

- reflexos condicionados, estudados profundamente por Pavlov, onde o estimulase a mesma resposta a determinados estímulos externos;

- reflexos intelectuais ou elementares, nos quais é necessária a interação com um objeto real, ressaltando-se a memória primitiva e eidética, onde as características físicas dos objetos são utilizadas em situações práticas;

- desenvolvimento de sua consciência;

- maturação das funções psicológicas superiores, onde a mediação é inserida como elemento para se alcançar o objetivo previamente estipulado. Nesta etapa, através da utilização de signos e códigos verbais/lógicos, as habilidades abstrativas da memória lógica, pensamento verbal, atenção voluntária e formação de conceitos são privilegiadas, possibilitando a apropriação de esquemas através do modo discursivo e lógico-verbal, não sendo necessário recorrer à experiência imediata.

Além disso, o homem difere dos animais por uma característica: ele não é apenas um produto da natureza, mas um agente ativo que vai se libertando através das relações sociais de trabalho que o indivíduo mantém com o mundo. $\mathrm{O}$ homem, enquanto modificador de seu ambiente, tem a exclusiva capacidade de planejar, antecipadamente, um evento em sua mente, apresentando a possibilidade de ser o estímulo e excitante dele mesmo, ou seja, é possível desenvolver a coordenação e organização de seus próprios atos e comportamentos, surgindo a autoconsciência.

A noção de consciência no viés da teoria sócio-histórico-cultural está, em um primeiro momento, ligada às teorias de reflexologia de Pavlov, onde um ser pode ser condicionado a respostas imediatas quando submetido a um reflexo contínuo. Entretanto, a consciência não é simplesmente um reflexo, mas um mecanismo de transmissão entre sistemas de reflexos, possibilitando que um reflexo primário se transforme em reflexos secundários, possibilitando a afecção da realidade a outros 
campos mentais. Nesta linha de pensamento, a consciência é a forma mais elevada de reflexo do mundo real (LURIA apud RIGON, op.cit.), sendo usada pelos homens para orientá-los no ambiente, não apenas adaptando-se, mas estruturando-se.

Segundo Rigon (op.cit.), para que esse mecanismo de transmissão (consciência) possa funcionar, é necessária a existência de um estímulo do mundo externo que movimente outros mecanismos, transmitindo uma mensagem (representação) que corresponda a uma realidade, que, por sua vez, possa influenciar outros sistemas. O processo de desenvolvimento da consciência, enquanto reflexo da realidade, é resultado direto da característica humana de submeter suas atividades às relações sociais desde sua origem, sendo fundamental que o agente estimulante se demonstre útil para o receptor.

A reflexão dos processos pelos quais o homem captura os estímulos exteriores é o que apóia a possibilidade de autoformação do indivíduo, a chamada consciência racional do processo ou autoconsciência. Nesta etapa do desenvolvimento psíquico, as ações mostram-se intencionais e voluntárias.

Seguindo a caracterização supra-referida do processo de consciência humano, ressalta-se que as ações realizadas pelo indivíduo em seu convívio social são geradas mediante o processo de internalização, onde os agentes estimulantes do mundo externo (relações interpessoais) buscam alterar os mecanismos internos do sujeito (relações intrapessoais), sendo que para a ocorrência destas alterações, conforme já exposto, é preciso que o estímulo tenha um caráter útil para a consciência. Se as características anteriormente citadas forem satisfeitas, teremos o que a linha de pensamento sóciohistórico-cultural define como atividade, uma ação especificamente humana, criada no relacionamento social, conscientemente orientada, de tal forma que o objeto de estímulo seja igual ao objetivo/finalidade do sujeito (VIGOTSKY, 2009, p.14).

Desenvolvida inicialmente por Lev Vigotsky, o termo atividade ganhou dimensões de teoria com Aléxis Leontiev (1903-1979) em meados da década de 30, ganhando seguidores contemporâneos - Galperin, Bozhovich, Levina, Luria e Rubstein - e estudiosos mais recentes, como o psicólogo finlandês Y. Engestrõm e Michael Cole.

A atividade, cuja maior expressão é o trabalho, é a principal mediação nas relações que os sujeitos estabelecem com os objetivos, colaborando com o desenvolvimento da consciência. Na base da ideia de atividade externa está um 
princípio central do materialismo dialético,onde o desenvolvimento psíquico do homem se realiza mediante apropriação da cultura através da comunicação com outras pessoas. Os processos de comunicação e as funções psicológicas superiores envolvidas neste processo se efetivam, primeiramente, na atividade externa (interpessoal) que, em seguida, é internalizada pela atividade individual, regulada pela consciência. A cultura, portanto, desempenha um papel relevante, por permitir ao ser humano a interiorização dos modos historicamente determinados e culturalmente organizados.

A apropriação das formas da cultura pelo indivíduo é, a nosso juízo, o caminho já elaborado de desenvolvimento de sua consciência (DAVYDOV, 1988 apud LIBÂNEO, 2004, p.2).

Segundo Sforni (2004), cada sujeito em particular, ao apropriar-se dos instrumentos e signos criados socialmente, reproduz, em nível individual, as formas histórico-sociais da atividade. Tal apropriação inicial está vinculada à participação do indivíduo na coletividade onde aquele instrumento ou signo é socialmente significativo. Por meio das internalizações, a realização da atividade, que era coletiva e externa, converte-se em individual, e os meios de sua organização, em internos.

Leontiev (s/d) estabelece uma estrutura psicológica para a atividade humana, incorporando os termos Necessidade - Motivo - Finalidade - Condições para se obter a finalidade, sendo que estes dois últimos componentes (a finalidade, bem como as condições para obtê-la) formam o que o autor chama de tarefa, Esta sequência de eventos, juntos, formariam a atividade.

A título de exemplificação, consideremos uma tribo que pretende caçar elefantes. Para a efetivação da caçada, alguns indivíduos tem a tarefa de afugentar os elefantes para a região onde o restante das pessoas os aguardam para acertá-los com lanças. Apesar do evento de afugentar os elefantes apresente-se, a princípio, como conflitante com a caçada dos mesmos, em conjunto com as demais tarefas, o grupo consegue o intento da realização da atividade de caçar os animais, que era sua necessidade geradora do motivo da caçada.

A necessidade é o fator desencadeador da atividade; motiva o sujeito a ter objetivos e realizar ações para supri-las. Considerando esta definição de atividade, infere-se que nem todo processo é uma atividade, mas somente aquele que é movido por uma necessidade. 
Designamos pelo termo atividade, os processos desencadeados pelo fato de aquilo para que tendem no seu conjunto (o seu objeto) coincidir sempre com o elemento objetivo que incita o paciente a uma dada atividade, isto é, com o motivo (LEONTIEV, s/d, p.34).

Com base no exposto, Sforni (op.cit., p.12) estabelece algumas premissas no desenvolvimento de uma atividade:

- para que uma ação tenha significado para o sujeito,é necessário que ela seja produzida por um motivo;

- para que as ações passem para um lugar inferior na estrutura da atividade, ou seja, transformando-se em operações, é preciso que novas necessidades ou motivos exijam ações mais complexas;

- para que, subjetivamente, o sujeito sinta novas necessidades ou motivos que o estimulem a agir em um nível superior, é preciso que esteja inserido em um contexto que produza, objetivamente, a necessidade de novas ações.

- para que uma operação seja automatizada de forma consciente, é necessário que ela se estruture, inicialmente, na condição de ação.

Apropriar-se de uma situação não significa apenas definir e operar com a mesma, mas, sobretudo, fazer-se consciente da estrutura conceitual empregada, exigindo uma nova qualidade de organização - o pensamento teórico (SFORNI, op. cit.), onde a reflexão, enquanto tomada de consciência por parte do indivíduo das razões de suas ações e de suas correspondências com as condições iniciais, é fundamental para a proposição de novas ações em um nível cognitivo mais elevado, gerando a operacionalização das atividades anteriores.

Segundo Libâneo (2004), em estudos recentes sobre a teoria da atividade, uma maior importância ao contexto vem sendo conferida. Todas as ações individuais devem ser interpretadas tendo em conta questões e fatores que não estão imediatamente presentes na situação, nem nas condições exclusivamente das pessoas que atuam nestas situações (CHAIKLIN \& LAVE, 2001 apud LIBÂNEO,op. cit., p.5).

Em uma análise cronológica da evolução da teoria da atividade, Libâneo (op. cit.) identifica três gerações de estudos sobre o tema: em um primeiro momento, atribui- 
se a Vigotsky a definição de atividade como mediação, gerando o modelo triangular sujeito - artefatos culturais - objetivo, onde os artefatos tem a exata função de ligação entre o sujeito e seu objetivo. Uma segunda etapa, corresponde às contribuições de Leontiev na elaboração da estrutura psicológica da atividade, enquanto que a geração mais recente é representada, principalmente, por Engestrõm, onde o modelo triangular vigotskyano é retomado, sendo realçado, porém, os conceito de contradições externas como força motriz dos sistemas de atividade e das diversidades culturais.

Da mesma forma que são encontradas muitas interpretações dentro da psicologia Sócio-Histórico-Cultural, também existem diferentes caminhos interpretativos em relação à teoria da atividade - talvez a mais importante divergência seja a concentração de Leontiev em atividades práticas e, Vigotsky, nos elementos da cultura e linguagem como fomentadores de necessidades. Porém, todas as linhas de pensamento, da vanguarda russa até os estudos mais modernos, baseiam-se nos mesmos fundamentos epistemológicos, vinculados ao materialismo histórico-dialético. Tais fundamentos, em particular aqueles relacionados ao ato criativo humano enquanto uma atividade, iniciam-se com os primeiros trabalhos psicológicos de Lev Vigotsky.

\subsection{Vigotsky e a criação}

Segundo Vigotsky (2009, p.12), chamamos atividade criadora humana aquela em que se cria algo novo, pouco importando se o que se cria é algum objeto do mundo externo ou uma construção da mente ou sentimento. $\mathrm{O}$ ato de criar é uma função psicológica comum a todos, podendo ser desenvolvido. É atribuído a dois tipos de comportamento humano:

a) Atividade reconstituidora ou reprodutiva: é ligada à memória, consistindo em reproduzir ou repetir meios de conduta anteriormente criados e elaborados ou ressuscitar marcas de impressões precedentes (no caso de lembranças de viagens ou elaboração de desenhos de observação, por exemplo). A base desta atividade é a plasticidade, definida pelo autor como a propriedade de uma substância que permite que ela seja alterada, mantendo as marcas deste processo.

b) Atividade Criadora ou Combinatória: Através de elementos de experiências anteriores, o cérebro humano apresenta a capacidade de combinar e 
reelaborar, de forma criadora, tais elementos, possibilitando novas situações e comportamentos.

Quando imagino a vida do homem no futuro, não estou recorrendo à impressões anteriores. Apesar disso, através da imaginação, posso ter uma ideia (...) o cérebro não é apenas o órgão que conserva ou reproduz(...) mas também o que combina e reelabora(...) a psicologia denomina de imaginação ou fantasia $^{14}$ essa atividade criadora (VIGOTSKY, 2009,p.12).

Para Vigotsky, a imaginação, apesar de apresentar a conotação de algo não-real, não-sério, é a base da atividade criadora; todo o mundo da cultura, diferente da natureza, é produto da criação e imaginação humanas. Qualquer invenção(...) antes de firmar-se(...) manteve-se íntegra como uma construção erigida na mente por meio de novas combinações ou correlações, apenas pela imaginação(...) Podemos dizer que todos objetos da vida cotidiana são imaginação cristalizada (p.15 - grifo nosso). Ainda para o autor, a criação está em toda situação onde o homem imagina, modifica, combina e cria algo novo, mesmo que seja um grãozinho perto das invenções do gênios.

Se levarmos em conta a imaginação coletiva que une estes grãozinhos, veremos que, grande parte do que foi criado pertence à união de várias criações anônimas (VIGOTSKY, op. cit.,p.16).

Para Vigotsky, uma das principais formas de desenvolver a atividade criadora é, pois, desenvolver a imaginação. Segundo o autor, tal desenvolvimento pode ser constatado facilmente nas brincadeiras infantis - o brincar da criança não é uma simples recordação plástica do que vivenciou,mas uma constante reelaboração criativa de impressões vivenciadas que responde a aspirações e anseios daquele momento. Em convergência, para Japiassu (2001), os processos criativos refletem-se, sobretudo, no brinquedo (jogo dramático infantil) em que ocorre a edificação espontânea de novas realidades de acordo com seus desejos, necessidades e motivações - tudo que edifica a fantasia influi reciprocamente nos sentimentos do indivíduo, e ainda que esta construção em si não concorde com a realidade, provoca sentimentos reais para quem a experimenta (o que Vigotsky nomeia de lei da realidade dos sentimentos).

\footnotetext{
${ }^{14}$ Para Vigotsky, os termos imaginação e fantasia são utilizados como sinônimos, ao contrário do exposto por outros psicanalistas, como Freud, por exemplo. Ver FREUD, 1934 apud VASCONCELOS, 2001.
} 
Ressalta-se, porém que, quanto mais rica for a experiência humana, tanto maior será o material disponível para a imaginação - o ímpeto para criação é sempre inversamente proporcional à simplicidade do ambiente (VIGOTSKY, op.cit.) - é necessário, portanto, ampliar a experiência cultural do indivíduo para que este alcance patamares criadores mais elevados. Neste sentido, Vigotsky infere que, ao contrário do senso comum, a imaginação ( e por consequência, a criação) do adulto é mais rica que a da criança, face a enorme diferença de experiências vividas por cada um. A criança vive mais tempo no mundo fantasioso, com ausência da exigência, o que implicaria em um número de possibilidades imaginativas maior. Segundo o autor, enquanto a criança cria em quantidade, o adulto o faz em qualidade:

A diferenciação entre a criança $e$ o adulto é puramente convencional, tendo o objetivo de diferenciar algo mais desenvolvido de algo ainda em desenvolvimento(...) as etapas criativas desenvolvem-se da mesma forma (p.147).

A imaginação no adulto dar-se-á em um ambiente onde os interesses e as relações com o meio atingem um patamar mais complexo, exigindo, desta forma, um maior grau de maturação criativa. Para esta linha de pensamento, à medida que esta maturidade se aproxima, a potente ascensão da imaginação une-se com $o$ desenvolvimento do intelecto no nível superior (abstração), surgindo os interesses permanentes e a forma final da atividade criativa. Vigotsky, em palestra realizada em 1908, procurou representar graficamente este processo:

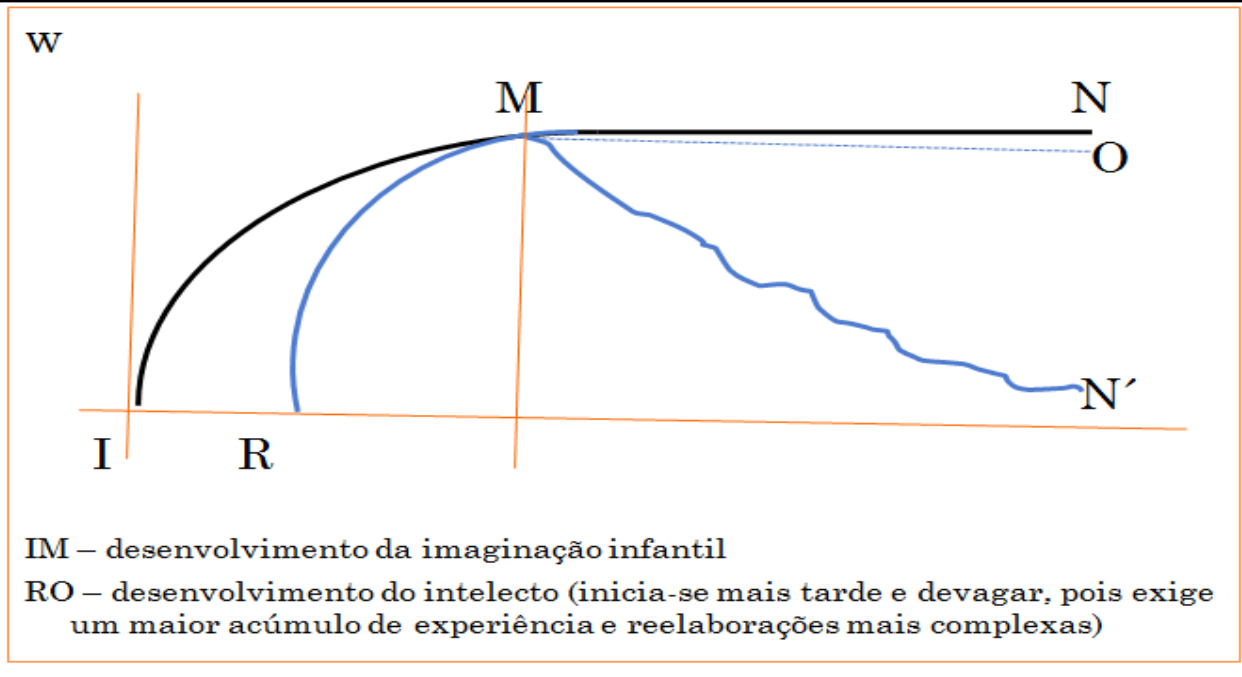

Fig.7 - Representação gráfica do desenvolvimento do intelecto e do imaginário (extraído de Vigotsky (2009)) 
$\mathrm{Na}$ figura anterior, a curva IM representa o desenvolvimento infantil da imaginação, enquanto que a curva RMO representa o desenvolvimento do intelecto. Nota-se que este último apresenta um início mais tardio e ascensão mais lenta, pois exige um maior acúmulo de experiência e reelaborações mais complexas. O ponto de junção das curvas representa a maturidade do indivíduo, sendo que, a partir dele, a imaginação e o pensamento seguem no mesmo ritmo, ocorrendo uma adaptação da imaginação às funções racionais.

A curva $\mathrm{MN}^{\prime}$ representa um retraimento que algumas pessoas podem sofrer em seu processo criativo devido a falta de estímulo do meio onde vivem. Ressalta-se que, segundo Vigotsky, este fato trata-se de uma regressão, e não um aniquilamento, sendo possível que, mediante agentes estimuladores adequados, o indivíduo possa vir a recuperar seu potencial criador.

No período de transição, ocorre uma profunda reestruturação da imaginação - é a idade da transgressão do equilíbrio do organismo infantil para um equilíbrio ainda não encontrado do organismo adulto, o que faz com que o adolescente se transforme em um ser crítico às formas imaginárias infantis.

Mas afinal, como ocorre a atividade criadora de combinação ou criação? A psicologia vigotskiana constata que cada período característico da infância tem sua forma característica de criação;além disso, não se pode esquecer de que ela depende diretamente de outras formas de atividade, em particular do acúmulo de experiência. Desta forma, esta linha de pensamento estabelece quatro formas possíveis de relação entre a imaginação e a realidade externa ao indivíduo:

- Toda obra de imaginação constrói-se sempre de elementos tomados da realidade e presentes na experiência anterior da pessoa. Portanto, a atividade criadora da imaginação depende diretamente da riqueza e da diversidade de experiências anteriores. Vigotsky (2009) salienta a necessidade de, pedagogicamente, ampliar a experiência da criança na escola para criar bases sólidas em sua atividade de criação.

- Mais complexa que a anterior, relaciona o produto final da fantasia e um fenômeno complexo na realidade. Para exemplificação, considere-se uma criança que, baseada na linguagem de um conto, consiga elaborar imagens nunca vivenciadas de um deserto. Neste caso, o indivíduo 
utiliza elementos da realidade, porém os reelabora de modo complexo, só possível através de um grande repertório ocasionado pela experiência social.

- A imaginação pode ocasionar o aparecimento de um caráter emocional real, gerando sentimentos no indivíduo que imagina face a sua entrega ao mundo da criação.

- O imaginado pode vir a adquirir uma forma real (objeto, máquina,palavra...), fato chamado por Vigotsky de imaginação cristalizada.

Através das formas relacionais acima, os elementos do imaginário são hauridos da realidade, submetem-se a uma complexa reelaboração, transformam-se em produtos da imaginação e, "se encarnam", retornando à realidade. Segundo o autor, este seria $o$ círculo da atividade criativa humana que, em nosso ponto de vista e resguardadas as devidas proporções, é análogo ao ciclo de ideias docentes proposto no modelo de Raciocínio Pedagógico (SHULMAN, 1987), analisado no capítulo anterior. Neste modelo de raciocínio, o professor, também parte dos objetos de sua realidade (prática) e experiências anteriores, reelabora estas informações em um complexo sistema de transformação, podendo vir a formar um novo PCK (o que Vigotsky talvez chamasse de “conhecimento cristalizado"). Dentro desta linha os processos de reelaboração citados, segundo Vigotsky (op.cit.), podem ocorrer na forma de:

- Associação/Dissociação: os elementos da realidade representam em si um todo complexo, composto de múltiplas partes separáveis. Tais elementos, ao serem inseridos nos esquemas cognitivos, podem tanto ser separados, como reunidos a outros esquemas, com o objetivo de criar.

- Exacerbação/Atenuação: de acordo com a necessidade momentânea do indivíduo, os fatos advindos da realidade podem ser atenuados ou exagerados.

Exageramos porque queremos ver as coisas de forma exacerbada, porque isso corresponde a nossa necessidade(...) o exagero resulta do interesse por sentimento de orgulho pela posse imaginária de algo especial (p.37). 
Enfatiza-se, portanto, que a imaginação não se reduz ao devaneio ou a uma capacidade fantasiosa de caráter estritamente individual; seu desenvolvimento é de natureza social. Integrando o sistema de funções psicológicas superiores, ela se articula à atividade voluntária e à elaboração da consciência na dicotomia das leis do real/irreal. Portanto, a atividade criadora tem papel fundamental na orientação das ações e na construção da vontade, seja individual ou social, viabilizando e potencializando a realização de projetos e a produção do novo.

\section{O Ato Criativo Inovador como Atividade Docente}

Inserida na linha de pensamento sócio-histórico-cultural, mais precisamente nas afirmações de Lev Vigotsky (2009), criar é uma atividade intrínseca e exclusiva do ser humano, sendo regida pelo esforço do indivíduo, não apresentando relação hereditária ou com a precocidade do gênio. Ao analisarmos a contribuição de Piaget ${ }^{15}$, constata-se que o autor corrobora com a ideia da não transmissão genética da criatividade, enfatizando a necessidade de se ler muito e fora de sua área específica de atuação para desenvolver esta capacidade humana de abstração reflexiva.

No ambiente escolar, apesar de comumente se verificar a necessidade expressa em artigos de um professor criativo, não se pode deixar de enfatizar que a criação docente não pode ser reduzida a um simples termo com variados significados no senso comum e acadêmico. Desta forma, voltamos a enfatizar, desta vez baseado nos comportamentos humanos sugeridos por Vigotsky, que ao inserir um novo elemento em sua prática pedagógica, o professor pode atuar de forma reprodutora ou criadora.

A atividade reprodutora refere-se à simples incorporação de uma prática ou elemento pedagógico já conhecido pelo docente, seja de sua própria experiência ou de seu contexto externo. Salienta-se, portanto, que a atividade reprodutora não apresenta um valor, necessariamente, negativo; a repetição de atividades com comprovada eficiência didática tem um caráter generalizador desta prática. Entretanto, também vale salientar que este tipo de intervenção, segundo a definição da teoria vigotskiana exige a total transposição do elemento ou prática de um contexto para outro, não se preocupando, sequer, com as possíveis adaptações que surgem nesta transferência de meios de aplicação.

\footnotetext{
${ }^{15}$ Palestra realizada em 1972. Ver Vasconcelos (2001, pp. 11-20)
} 
Quando a adaptação é solicitada, ou ainda, quando a confecção de uma prática nova se faz necessária, trabalha-se com uma atividade criadora de ensino, onde, parafraseando Vigotsky (2009.), (...) através da imaginação (...) surge a ideia, a criação de novas imagens ou ações. Dentro da prática pedagógica criadora, onde novos elementos são inseridos na prática docente, podemos estabelecer diferentes níveis de criatividade, em particular, a possibilidade da inserção das novidades no contexto que consigam firmar-se e trazer melhorias na aprendizagem discente, o que, conforme a classificação prévia inserida na introdução deste trabalho, classificamos como ato criativo inovador ou inovação educacional.

Desde a reprodução com interação criativa quase nula, passando pela criação, ou inovação, é importante que tais práticas sejam consideradas atividades pelo docente, ou seja, no sentido histórico-cultural, é preciso que elas não sejam vistas como um conjunto de ações alienadas. Independente do contexto estabelecido pelo docente na condução de sua aula, é vital que o professor tenha tomado consciência do processo e suas consequências, tenha refletido sobre as condições de aplicação do mesmo, fatores estes que surgirão naturalmente se estivermos tratando de um conjunto de ações movidos por motivos e necessidades significativos a este docente. Na estrutura psicológica da atividade, pode-se inferir que estes fatores como necessidade, motivo, reflexão, tomada de consciência e condições para obter a finalidade podem ocorrer em diferentes patamares, sugerindo diferentes níveis de ações criativas. Não menos importante, é que este professor tenha claro que, dentro dos padrões de atividade, a finalidade deste processo é idealmente fixa e apenas uma - a melhoria da aprendizagem discente.

Diante deste contexto, volta-se a salientar que, para o alcance destes objetivos, não podemos estar tratando de um professor estritamente técnico, onde a reprodução com criação nula é a regra da prática, não sendo vislumbradas possibilidades de adaptações ao sistema que procurem uma maior eficiência no processo de aprendizagem. Por outro lado, a formação de professores nos patamares reflexivo e crítico sugere um profissional com níveis criativos mais elevados, mais adaptado às criações que urgem no contexto da prática, sendo, portanto, uma atividade criadora, com motivos/necessidades próprios e com significado, condições para que estas necessidades sejam satisfeitas, reflexão/tomada de consciência das etapas do processo, bem como 
sua avaliação, podendo, desta forma, nascer a criação de novos elementos favoráveis à aprendizagem, fechando-se, desta forma, o ciclo criativo vigostkiano.

Portanto, neste trabalho, devido às inerentes questões sócio-culturais associadas ao desenvolvimento criativo docente na elaboração de um saber pedagógico de conteúdo (também cultural, portanto), adotaremos, em conjunto com o referencial sócio-histórico-cultural da escola vigotskiana, a teoria de equilibração de acordo com as últimas obras de Piaget e com os trabalhos mais recentes (SINCLAIR et al, 1985, FERREIRO, 1986, CASTORINA \& GIL ANTÓN, 1994, por exemplo), onde assume-se o contexto das condições de ensino e interação com os professores e demais agentes culturais em complexas relações sociais, porém admitindo-se, de forma indispensável, a existência do mecanismo cognitivo interno.

Apesar desta posição poder aflorar uma precipitada interpretação de uma certa incoerência entre a equilibração piagetiana e a aquisição de conhecimentos na chamada zona de desenvolvimento proximal ${ }^{16}$ vigotskiana, Castorina (op.cit.) esclarece que "admitindo as raízes das perguntas que originaram ambos os programas, não existe incompatibilidade entre o construtivismo e a aquisição de conhecimentos na ZDP”, tampouco entre as visões piagetianas e vigotskianas, desde que se deixem claras as limitações e o horizonte de atuação de cada uma, conforme será tratado a seguir.

\section{Piaget e Vigotsky: divergências e aproximações na justificativa da criação de uma articulação para o estudo da criatividade}

Conforme exposto no decorrer deste capítulo, optaremos pela utilização em conjunto de extratos das teorias vigotskiana e piagetiana na tentativa de alicerçar um referencial teórico que abranja os principais pontos do desenvolvimento e caracterização da criatividade no campo pedagógico, mais especificamente no trabalho docente de elaboração de saberes pedagógicos de conteúdo, nos moldes daquele exposto por Shulman (1987 e 2004).

A utilização dos programas propostos por Piaget e Vigotsky em conjunto costuma gerar debates que apontam a inconsistência entre os autores no tocante a suas teorias na apreciação e orientação da prática educacional. Segundo Castorina (2008,

\footnotetext{
${ }^{16}$ Vigotsky denomina Zona de Desenvolvimento Proximal (ZDP) como o conhecimento que uma criança não conseguiria adquirir sozinha, mas apenas mediante o auxílio de um adulto ou par mais experiente.
} 
p.43), para muitos teóricos e profissionais da educação, tornam-se evidentes o conflito irredutível e a necessidade de optar entre os mesmos (...), porém, tal versão parece estar apoiada em leituras superficiais e errôneas dos textos clássicos e primeiros trabalhos de ambos os autores.

De fato, o próprio Vigotsky (2001), em seu livro A Construção do Pensamento e da Linguagem, dedica quase uma centena de páginas ao estudo da teoria piagetiana, corroborando com sua importância:

Com o auxílio do método clínico, Piaget foi o primeiro a estudar sistematicamente, com ousadia incomum, profundidade e amplitude de abrangência, as peculiaridades da lógica em um corte inteiramente novo (p.19).

Segundo Lerner (2008), a aparente necessidade de opção entre as teorias reflete uma discussão inacabada e, como afirmou Castorina (op. cit.), superficial:

Uma moda está percorrendo alguns âmbitos educativos: opor - considerando-os antagônicos - o enfoque didático "piagetiano" e o enfoque didático "vigotskiano”. A oposição é colocada aproximadamente nos seguintes termos: os piagetianos colocam em primeiro plano o desenvolvimento operatório ou o funcionamento cognitivo geral, enquanto os vigotskianos centram-se na transmissão dos conteúdos escolares, isto é, dos saberes culturais; ou ainda, enquanto os primeiros enfatizam a produção individual do conhecimento, os segundos atribuem grande importância à construção social; os primeiros minimizam a intervenção docente, enquanto os segundos consideram que essa intervenção é fundamental para aprendizagem (p.89).

Na mesma linha, podemos ainda citar a crítica direta feita por Coll (1990), com relação à construção social do conhecimento:

Assim(...)em teorias de base piagetiana, o aluno é percebido como ser socialmente isolado, que deve descobrir por si mesmo as propriedades dos objetos(...), vendo-se privado de toda ajuda ou apoio originado dos outros seres humanos. A centração quase exclusiva nas interações entre o aluno e um meio essencialmente físico provoca menosprezo pelas interações do aluno com seu meio social (p.99). 
Apesar da radical posição defendida por Coll, neste mesmo capítulo, quando do tratamento a respeito da teoria de equilibração piagetiana, procuramos deixar nitidamente exposta a relação com o social proposta por Piaget em seus trabalhos originais (principalmente, após a década de 70) e as mais recentes interpretações de seu trabalho, onde o contexto social não é tratado como mero facilitador da aprendizagem, mas como aporte fundamental do processo. Em Piaget (1974), o autor esclarece que "se tivéssemos que escolher entre o conjunto de sistemas psicológicos que correspondessem melhor aos nossos resultados psicológicos, tentaríamos orientar o nosso método àquilo que foi denominado "o trabalho em grupo" (...) a cooperação eleva-se à categoria de fator essencial do progresso intelectual”.

A importância outorgada à elaboração cooperativa do conhecimento no âmbito escolar, procura, mais uma vez, deixar consistente o papel atribuído pela teoria piagetiana aos fatores sociais que incidem no desenvolvimento cognitivo e que, segundo Lerner (op. cit.), em uma análise mais recente, está vinculada a chamada Psicologia Genética Social, que permite compreender melhor a ação destes fatores na construção do conhecimento. Neste campo, face à importância destinada ao meio cultural, o termo "conflito cognitivo" exposto por Piaget em sua teoria de equilibração, é denominado como "conflito sociocognitivo". Segundo Castorina \& Barquero (2008), "é necessário ampliar a dialetização piagetiana de gênese e estrutura (...) é preciso tratar do "conhecimento de domínio", ou seja, centrar-se na elaboração de hipóteses e teorias adequadas às peculiaridades de diferentes campos do mundo social (p.51)”. Ainda segundo os autores, é necessária, no campo da Psicologia Genética Social, a realização desta extensão não literal das ideias de Piaget para perceber a formação dos conhecimentos em diferentes domínios relativos às instituições sociais:

No caso de certos conhecimentos sociais (...) quando os sujeitos os convertem em objeto de conhecimento, estes atuam sobre os sujeitos, prescrevendo-lhes o que devem e não devem fazer (...) sem os saberes da participação social não há conceitos (CASTORINA \& BARQUERO, 2008, p.52).

Em Piaget (1975) apud Lerner (2008), é inferido que, no enfoque piagetiano de pesquisas realizadas em meios socioculturais muito diferentes, enuncia-se que, junto aos fatores biológicos e de equilibração, existem fatores sociais de dois tipos: os de 
coordenação interindividual - gerais para todas as sociedades - e os de transmissão educativa e cultural, próprios de cada sociedade, enfatizando que esta troca intelectocultural intervém durante todo o desenvolvimento. Piaget considera, ainda que, a socialização do pensamento é progressiva, e que uma cooperação verdadeira só é possível a partir do nível operatório concreto, gerando uma interdependência entre o sujeito e o meio.

Portanto, parece-nos clara a relação de que Piaget atribuía uma importância considerável aos fatores sociais que incidem no desenvolvimento. Segundo Castorina \& Baquero (2008), as críticas que dizem respeito a questão social aparecem, principalmente, devido ao fato dos estudos posteriores a Piaget, realizados por seus colaboradores imediatos, terem se centrado, sobretudo, na equilibração das estruturas cognitivas, sendo que os trabalhos em Psicologia Genética Social ocorreram posteriormente, sendo a atual base para a maioria dos trabalhos, inclusive este, realizados neste contexto. Insiste-se, portanto, na importância do fator social nas teorias construtivistas desenvolvidas no âmbito piagetiano. Esta proposta, além de agir proporcionando um "alimento social” (Lerner, 2008) a ser assimilado, também exige do sujeito uma acomodação que por si mesma é "criadora de novidade e fator causal no dinamismo da evolução mental" (Ibidem).

De acordo com Vigotsky (2001), a teoria Piagetiana surgiu em um momento de crise na área, o que corrobora com o surgimento de "muitas psicologias(...), mas não existe uma psicologia una, existem várias possíveis (p.22)”. Ainda segundo o autor, Piaget, ao unificar o egocentrismo infantil e a colaboração entre os sujeitos (mecanismo este chamado de coação), deixa clara "sua concepção sobre o mecanismo através do qual o meio social dirige o desenvolvimento do pensamento(...) ele [o meio social] $^{17}$ é visto como algo exterior em relação ao indivíduo, que o obriga a limitar, modificar e orientar suas ações pelos devidos caminhos (p.79)".

Apesar de diversos psicólogos considerarem as teorias de Piaget e Vigotsky como versões opostas sobre o desenvolvimento intelectual, podemos verificar que ambos os programas apresentam nítidos pontos comuns - como por exemplo a constituição de sistemas estruturais como a chave do desenvolvimento da inteligência e

\footnotetext{
${ }^{17}$ Apesar de, claramente, constatar que Piaget considera o meio social em sua obra, Vigotsky efetua uma crítica ao não aprofundamento de Piaget neste tópico, afirmando que nesta teoria, o sujeito não é considerado, efetivamente, como parte de uma rede social de relações, mas como pressionado ou reprimido por este último.
} 
a ênfase na atividade do sujeito na aquisição do conhecimento - mas, também, divergências - como o fator decisivo dado por Vigotsky à interação social e aos fatores lingüísticos, a aprendizagem sendo gerada pelo desenvolvimento na versão piagetiana e, o oposto,na versão vigotskiana, a complexa estrutura cognitiva proposta pela teoria construtivista, ao contrário do não aprofundamento neste setor pela teoria históricocultural.

Diante deste quadro, concordamos com o ponto de vista de Castorina (2008), Lerner (2008) e Ferreiro (1983 e 1994), onde a chave da possibilidade de comparação está no fato de que as perguntas que Piaget e Vigotsky tentaram responder não eram as mesmas, o que, portanto, possibilitaria uma compatibilidade entre os referenciais teóricos propostos.

No patamar vigotskiano, o objetivo era obter uma explicação sócio-histórica da constituição das funções psicológicas superiores a partir das inferiores, ou seja, de que forma o pensamento e a memória são transformados de funções primárias em funções especificamente humanas. Para dar continuidade a este quadro, Vigotsky apóia-se na intervenção dos sistemas de signos produzidos pela cultura, mais especificamente em âmbito escolar, como formadores da atividade psicológica.

Já na análise da obra piagetiana, verifica-se que as interrogações são diferentes por estarem vinculadas à problemática epistemológica, ou seja, como se passar de um estado de menor conhecimento para outro de maior conhecimento? A psicologia, neste caso, é utilizada como um instrumento para compreender este processo de transição dos estados epistêmicos, resultando no sujeito transformando seu mundo de significados ao transformar sua relação com a realidade - tanto física como social.

Nas relações entre aprendizagem e desenvolvimento, constata-se uma divergência relevante entre as teorias, afinal, para Piaget, o desenvolvimento cognitivo geraria a aprendizagem, ao passo que para Vigotsky, a aprendizagem é o fator preponderante para a transmissão dos saberes culturalmente constituídos, gerando, desta forma, o desenvolvimento do indivíduo. Mais uma vez, é preciso expor que a divergência é relativa, afinal não se pode esquecer de que a teoria piagetiana, como já citado, foi desenvolvida fora da sala de aula, com bases epistemológicas. Conforme expõe Castorina (2008): 
(...) neste momento gostaria de salientar a insuficiência da pedagogia construtivista tal como foi resenhada. A teoria da aprendizagem foi elaborada fora da sala de aula e orientada à indagação de modificação das estruturas cognitivas(...) a transposição desta teoria para o campo educacional teve como resultado uma interpretação que converteu a construção de sistemas lógicos no objetivo da prática educacional e a atividade docente em criadora de situações que suscitaram a problematização dos alunos (p.25).

Conforme exposto no decorrer deste trabalho, as interpretações mais recentes da teoria construtivista e dos processos de equilibração, consideram a escola como local onde o objetivo central é a comunicação dos saberes historicamente construídos, sendo que boa parte deles não poderiam ser adquiridos pelos alunos sem uma intervenção docente de qualidade, diversa da requerida pelas primeiras versões "pedagógicas aplicacionistas" da teoria piagetiana. Conforme reforça Castorina (op.cit.)

Apesar de na prática educativa, indubitavelmente, existir preexistência de sistemas conceituais, valores $e$ procedimentos socialmente criados (...) não implica assumir uma postura epistemológica de cópia (...) mas possibilitar conflitos [sociocognitivos] durante o trabalho dos alunos com $o$ material escolar e mesmo fornecer informação com o propósito de suscitar a reorganização das ideias previas(...) podemos abandonar a tese de que a prática educacional deve ser dirigida para a formação de estruturas cognitivas, como condição suficiente para a aquisição dos saberes escolares (p.26)

Desta forma, o que se propõe, com base na comparação crítica entre as teorias de Vigotsky e Piaget, é uma extensão para um campo de problemas diferentes daqueles originados nas primeiras versões da psicogenética, intersectando conceitos dos dois programas em um estudo mais amplo do ambiente escolar. Segundo Paris \& Cross (1988), “a zona de desenvolvimento proximal representa uma metáfora iluminadora para um piagetiano sobre a aquisição de conhecimentos socialmente objetivados com a imprescindível ajuda dos outros".

Nesta visão, a aceitação da Zona de Desenvolvimento Proximal implica em aceitar a proposta vigotskiana do desenvolvimento através da aprendizagem, entretanto, desta forma assume-se o contexto das condições de ensino e interações com os 
professores juntamente com o "indispensável mecanismo cognitivo interno" (CASTORINA, 2008).

Diante do exposto, pode-se verificar que, em linhas gerais e através das análises das primeiras obras de Piaget e Vigotsky, o primeiro focalizou seu interesse na gênese da lógica dos conceitos, deixando em seus escritos hipóteses suficientemente articuladas e cuidadosas informações sobre os processos experimentais, enquanto que o segundo buscou o enfoque no contexto da aquisição escolar de conhecimento, porém, devido a sua morte precoce e a condição social russa de divulgação das pesquisas, transformouse em um comunicador de narrativas orais, aumentando a fragmentação de suas ideias (CASTORINA,op. cit.).

No presente trabalho de pesquisa, enfatizamos novamente que, dentro de uma perspectiva histórico-cultural vigotskiana, onde tratamos o docente como um ser social que, através de sua tomada de consciência via necessidade, gera atividades inerentes a sua profissão durante a elaboração de um saber pedagógico de conteúdo, também utilizaremos o referencial piagetiano, mais especificamente no tocante a sua teoria de equilibração com o intuito de articular e enriquecer nossas análises de dados em um patamar cognitivo interno (biológico).

Ressalta-se, entretanto, que não se trata de complementar, de maneira geral, a teoria vigotskiana com a piagetiana, haja vista tratarem-se de níveis de questionamentos diferentes, elaborados mediante metodologias opostas - o método clínico de Piaget, interpretando as hipóteses das crianças, e o método de indagação de Vigotsky, dirigido, sobretudo, a provar que as noções infantis podem ser melhoradas. Portanto, não se trata de ampliar os princípios explicativos da internalização até o início do desenvolvimento psicológico, tão pouco incorporar interações sociais complexas, como as tratadas por Vigotsky, na teoria de equilibração de Piaget. Como aponta Lerner (2008), "se a equilibração é o modo pelo qual o sujeito e o objeto de conhecimento são construídos, e se a formação dos conhecimentos pode ser interpretada como internalização dos instrumentos culturais, trata-se de articular os níveis de explicação, e não de completálos".

Segundo Castorina (2008), ao expormos com insistência a possibilidade social inserida dentro de uma nova visão piagetiana (trabalhada em aspectos diferentes daqueles explorados por Vigotsky) e uma ausência de aprofundamento nos processos cognitivos internos referentes à internalização cultural vigotskiana, afirma-se que a 
compatibilidade entre as teorias é possível, mas deve ser entendida de um ponto de vista mais amplo dos programas, pois devido à complexidade das linhas de pensamento, alguns postulados podem ser, de fato, incompatíveis e ineligáveis com relação a problemas comuns. No presente trabalho, porém, julgamos que os particulares aspectos trazidos de ambas as teorias tratadas nos permitem inferir em um caráter complementar das ideias, salientando sempre que esta situação ocorre no específico contexto desta pesquisa, onde buscamos a elaboração de um referencial peculiar que abarque o processo criativo humano.

Neste capítulo buscamos, portanto, expor em linhas gerais os referenciais histórico-cultural em uma linha vigotskiana e a teoria de equilibração piagetiana com o objetivo de reforçar nossos referenciais teóricos em nível de abrangência, buscando cobrir, desta forma, uma maior gama de possibilidades inerentes ao desenvolvimento do processo criativo e de sua caracterização, problemas estes, fundamentais a nossa pesquisa.

Esclarece-se, pois, que a meta desta seção não é a realização de uma profunda análise comparativa crítica entre as teorias de Piaget e Vigotsky, o que demandaria estudos de caráter filosófico, histórico e epistemológico que fugiriam ao tema central deste trabalho. Novamente, esclarecemos que a busca deu-se, direcionada pelo desenvolvimento global deste trabalho, principalmente, na justificativa de uma possível articulação entre as visões dos dois autores no tocante à produção social do conhecimento e suas relações com o ensino e aprendizagem. Conforme nos aponta Lerner (2008), “ no plano didático, é possível ser piagetiano e ao mesmo tempo tomar como eixo a comunicação dos saberes culturais, colocar em primeiro plano a construção social do conhecimento e atribuir um papel fundamental à intervenção do professor nessa construção".

No próximo capítulo, abordaremos a pesquisa de campo realizada para a caracterização dos níveis criativos docentes na elaboração de sua prática pedagógica. Para tanto, delinearemos o contexto e os instrumentos utilizados em seu desenvolvimento, bem como a metodologia empregada. 


\section{CAPítUlO IV}

A PESQUISA 
Este capítulo tem como meta a exposição do trabalho de campo efetuado, buscando um delineamento do contexto onde ocorreu a pesquisa, bem como os instrumentos utilizados em sua metodologia.

Com base nos aportes teóricos expostos anteriormente, procuramos iniciar uma tomada de dados com o objetivo de caracterizar os processos criativos dos futuros professores quando da elaboração de conhecimentos pedagógicos de conteúdo, procurando identificar possíveis processos de criação, bem como o contexto onde estes ocorreram.

\section{O Contexto da Pesquisa}

Para obtermos os dados relativos à pesquisa, detivemo-nos na realização de um levantamento com cunho qualitativo e exploratório, buscando, desta forma, estabelecer os indícios acerca do processo criativo docente.

Para tanto, realizamos a coleta de informações com alunos do curso de Licenciatura em Física da Universidade de São Paulo (USP), que se encontravam regularmente matriculados na disciplina "Metodologia do Ensino de Física II".

Especificamente, concentramo-nos na turma única relativa ao $2^{\circ}$ semestre de 2012, que apresentava aulas semanais às quartas-feiras, no período do tarde.

Salientamos que a disciplina citada apresentou-se como contexto para uma aproximação entre o pesquisador e o tema deste trabalho, contribuindo para estudos mais centrados nos aspectos criativos das elaborações propostas pelos futuros professores. Mais especificamente, no tocante à diversidade destas criações, além do enfoque mais centrado na elaboração dos conhecimentos pedagógicos de conteúdo dos licenciandos quando do planejamento de suas ações em sala de aula, bem como de sua prática no estágio. A seguir, buscamos delinear esse contexto de atuação da pesquisa.

\subsection{A Disciplina "Metodologia do Ensino de Física II"}

A "Metodologia do Ensino de Física II", por ser parte integrante das disciplinas oferecidas pela Faculdade de Educação relativa à grade curricular dos cursos de licenciatura da Universidade de São Paulo (USP), apresenta como exigência para sua 
conclusão, a realização de estágio obrigatório em escolas públicas ou privadas de ensino médio, além de frequência e aproveitamento mínimo.

A disciplina em tela é de natureza obrigatória aos estudantes matriculados no curso de licenciatura em Física da Universidade e, de acordo com sua ementa, disponibilizada no site da instituição, apresenta como objetivos gerais:

a) a análise das opções curriculares do ensino de física em função de seu desenvolvimento histórico;

b) a identificação das concepções sobre ensino de física presentes em materiais didáticos;

c) a interpretação e definição de temas e percursos curriculares relativos ao ensino médio;

d) o vivenciamento e análise de atividades que incluam materiais curriculares inovadores;

e) a elaboração, implementação e avaliação dos programas de ensino em situação de estágio.

Desta forma, o programa da disciplina tem por meta estabelecer a integração entre os conteúdos de física, os pedagógicos, os trabalhos teóricos e as práticas nas escolas de ensino fundamental e médio. As atividades, em aulas e estágios, apresentavam, portanto, a intenção de levar os futuros professores a se debruçarem tanto sobre as condições determinantes de aprendizagem, o ensino e a produção de conhecimento físico em ambiente escolar.

No caso particular da turma analisada, a professora responsável pela disciplina ${ }^{18}$ buscava a criação de um ambiente de pesquisa entre os licenciandos, solicitando aos mesmos que, durante a realização do estágio propriamente dito nas unidades escolares, realizassem uma pesquisa em caráter exploratório, utilizando o contexto da sala de aula.

Tal projeto de estágio, com caráter investigativo, apresenta, portanto, dois eixos de trabalho, que comportam: a dimensão ensino, que tem o intuito de inserir os estudantes da licenciatura em física no ambiente escolar, propiciando sua aproximação com as questões inerentes às instituições escolares e à sala de aula; desse modo, tal face do estágio tem como o objetivo principal a proposição, por parte dos estagiários, de um

\footnotetext{
${ }^{18}$ A professora da disciplina é, também, a orientadora deste trabalho.
} 
conjunto de aulas (de 4 a 10h, aproximadamente) a serem ministradas pelos próprios futuros docentes, que abordassem um tema físico a sua escolha.

Já a dimensão pesquisa sobre o ensino, busca desenvolver nos alunos uma atitude investigativa de sua própria prática, mediante a resposta a uma questão de pesquisa desenvolvida pelo grupo e relacionada ao seu estágio. Tal procedimento pretende promover reflexões durante sua ação e após a realização da mesma, como propõe Schön (1992), as quais propiciariam, segundo Vigotsky (2009), futuras intervenções com um provável nível de consciência mais elevado e menor grau de alienação por parte do futuro docente, corroborando para o surgimento de situações de ensino movidas por necessidades legítimas e que trariam em seu objetivo uma real preocupação com a aprendizagem dos estudantes.

Em corroboração com Abib (2010), tal formato de prática de estágio compreende a necessidade do futuro professor comportar-se como sujeito responsável pela elaboração dos conhecimentos necessários para sua prática em sala de aula, rompendo com uma postura passiva que consideraria o estagiário como um elemento exterior ao conjunto dos problemas que afetam o processo de ensino e aprendizagem.

Para a realização destes objetivos, nas aulas da disciplina, com carga horária semanal de 4h, ocorriam discussões, além daquelas já descritas anteriormente, acerca da pesquisa sobre ensino de física, suas metodologias principais e resultados já obtidos na literatura da área. Os alunos, constantemente, realizavam discussões em grupo sobre os temas propostos em aula, socializando, posteriormente, suas conclusões com o restante da turma.

Tais resultados eram analisados pela professora responsável, sendo utilizados como uma das formas de avaliação da disciplina, além das sínteses individuais sobre os temas propostos, auto-avaliação, síntese final da disciplina e a entrega de pasta com todo o registro das atividades do licenciando ao longo do semestre (portfólio), sejam elas realizadas na universidade ou durante as dimensões de ensino e pesquisa propiciadas pelo estágio.

Desse modo, tais pontos geraram interesse acadêmico na disciplina "Metodologia do Ensino de Física II", contribuindo, portanto para sua melhor caracterização: 
- estágio em escolas públicas ou privadas - das 60h totais da disciplina, era exigida uma carga horária mínima de 30h de estágio em instituições de ensino, momento este onde os futuros professores, além de acompanhar docentes mais experientes, teriam a possibilidade de aplicar seus projetos de estágio criados.

- Sínteses e Textos Teóricos - produção de pequenas resenhas acerca dos temas abordados durante a discussão em sala de aula, buscando suas relações entre os referenciais teóricos apresentados e a vivência presenciada no estágio;

- participação durante as aulas - com o objetivo de promover um ambiente aberto, investigativo e dinâmico de ensino, visando a uma formação docente, ao menos, em um patamar reflexivo, as aulas previam a exposição dos pontos de vista dos discentes, procurando contribuir com o desenvolvimento de suas próprias reflexões durante seu processo formativo.

- Projeto de Estágio - realização de um conjunto de intervenções em sala de aula, durante o estágio, onde o licenciando aplicaria um projeto de sua criação que deveria, obrigatoriamente, abordar um tema sobre Física no contexto do Ensino Médio. Salientamos que os licenciandos possuíam total liberdade para a elaboração deste projeto, o qual deveria, como exposto anteriormente, contemplar as dimensões de ensino e pesquisa propostas pela diciplina. Salientamos que, apesar da liberdade quanto à criação do projeto, o tema do mesmo era definido em conjunto com o professor colaborador da escola onde ocorreria o estágio.

- Caderno de Campo - instrumento onde encontrar-se-iam os registros dos fatos ocorridos durante o estágio.

Conforme já exposto, todos os elementos acima estariam contidos em um portfólio, que seria entregue pelos estagiários ao final da disciplina. 


\subsection{A Supervisão na disciplina "Metodologia do Ensino de Física II"}

A disciplina "Metodologia do Ensino de Física II" apresentava aos seus alunos, como parte integrante da carga horária referente ao estágio obrigatório, reuniões semanais de $1 \mathrm{~h}$ de duração denominadas Supervisões. Tais encontros, que apresentavam uma gama variada de horários, buscando a adequação com a agenda dos estagiários e dos supervisores ${ }^{19}$, também apresentavam o objetivo de oferecer aos futuros professores um espaço de debate e exposição de suas vivências nos estágios, bem como o encaminhamento de alternativas para as possíveis dúvidas acerca dos temas abordados durante a aula ou da sua prática no estágio.

Nas supervisões, os licenciandos tinham a possibilidade de discutir a aplicação de seu projeto de estágio no ambiente escolar, desde sua criação até dúvidas, imprevistos e demais ocorrências que pudessem ocorrer no ambiente da sala de aula.

\subsection{Os Sujeitos da Pesquisa}

Para a realização da coleta de dados referentes à pesquisa em tela, este pesquisador foi responsável por coordenar a supervisão da disciplina "Metodologia do Ensino de Física II" realizada às quartas-feiras, entre 17h 40min e 18h 40min. Na citada reunião, participava um total de sete estudantes da licenciatura em Física matriculados na disciplina citada, sendo que estes perfaziam um total de três grupos de estágio.

Conforme caracterização mais detalhada que será realizada no capítulo V desse trabalho, os licenciandos participantes desta supervisão não apresentavam experiência docente anterior, senão aquela oriunda dos estágios obrigatórios realizados nas disciplinas oferecidas pela Faculdade de Educação da Universidade de São Paulo (USP). Por se tratar de um ponto da pesquisa onde buscamos elementos mais profundos acerca da criação dos conhecimentos pedagógicos de conteúdo por parte destes estudantes, optamos por concentrarmos nossas análises em dois grupos de estágio, denominados grupo I e II, que eram compostos, respectivamente, pelos alunos que iremos identificar pelos símbolos $(\mathbf{R}$ e $\mathbf{C})$ e $(\mathbf{A}, \mathbf{L}, \mathbf{W})$. A escolha de tais sujeitos deu-se em decorrência da maior quantidade e variedade de dados propiciados por estes

\footnotetext{
${ }^{19}$ A disciplina de Metodologia de Ensino de Física II, realizada no 2ㅇ semestre de 2012, apresentava dois supervisores, sendo um deles o autor deste trabalho, além de um bolsista do programa PAE.
} 
estagiários durante o processo de pesquisa, contribuindo para futuras conclusões acerca da temática desta pesquisa.

\section{A Metodologia da Pesquisa}

A pesquisa, aqui descrita, apresenta o objetivo de analisar os processos criativos dos futuros professores de física envolvidos na elaboração de um conhecimento pedagógico de conteúdo (PCK). Para tanto, optamos pelo ambiente da formação inicial dos futuros docentes, mais precisamente durante as práticas dos estágios ocorridas na disciplina "Metodologia do Ensino de Física II", oferecida regularmente na grade curricular do curso de licenciatura em Física da Universidade de São Paulo. Em um ponto de vista mais específico, as informações obtidas a partir dos estágios nos propiciaram uma primeira e mais geral análise acerca da criatividade docente, possibilitando-nos uma caracterização mais geral das possíveis intervenções criativas dos licenciandos. Em ato contínuo, os relatos obtidos com os futuros professores buscaram focalizar, em um aspecto mais profundo, a elaboração dos conhecimentos pedagógicos de conteúdos quando da prática do estágio, delineando, desta forma, os processos criativos intrínsecos a esta ação.

A interpretação de possíveis novos conhecimentos docentes surgidos será realizada, em um primeiro momento, através dos referenciais relacionados ao conhecimento pedagógico de conteúdo no contexto da formação inicial do professor. Em uma segunda análise, tais resultados também serão observados à luz de elementos das teorias psicológicas de Piaget e Vigotsky, os quais, apesar de serem partes de teorias, aparentemente antagônicas, em nossa visão, com enfoques adequados, mostraram um grau de complementaridade necessário aos referenciais cognitivo e social para o estudo dos processos criativos docentes.

Conforme exposto, os dados construídos nesta pesquisa referem-se à prática pedagógica dos licenciandos, dentro e fora do ambiente escolar, bem como as características criativas do processo de elaboração do PCK em tais ambientes. Tal fato nos leva a inferir que os possíveis levantamentos apresentavam características relacionáveis aos trabalhos de cunho qualitativo, caracterizando a pesquisa de campo realizada em um caráter qualitativo (cf. LUDKE \& ANDRÉ, 2008 e BOGDAN \& 
BIKLEN, 1994) e, para tanto, utilizamos diversos instrumentos que pudessem abarcar as informações disponíveis para posterior análise e categorizações.

Segundo Marandino et al. (2009), a pesquisa educacional no século XX foi marcada por uma mudança do paradigma quantitativo na direção de abordagens qualitativas. Tais alterações apresentam relações com as transformações sociais mais amplas desenvolvidas, especificamente, no campo educacional. Tais mudanças buscaram a incorporação dos processos na análise educacional, enfatizando o ambiente social e político que rodeia a prática escolar.

O investimento em novos suportes metodológicos almejava obter subsídios para o desenvolvimento de pesquisas de orientação mais interpretativa, que incorporasse os sujeitos como atores sociais (...) levando em conta suas práticas socialmente construídas (MARANDINO et al, 2009, p.4)

Segundo Johnson \& Onwuegbuzie (2004), a investigação em educação está se tornando cada vez mais interdisciplinar, complexa e dinâmica. Desta forma, torna-se cada vez mais necessária a adoção de métodos múltiplos que consigam misturar e combinar elementos que ofereçam uma melhor chance de resposta às questões propostas nas pesquisas. Convergente com este ponto de vista, Bogdan \& Biklen (1994), apontam que "a pesquisa qualitativa pode ser considerada como um grande guarda-chuva que abriga as diversas estratégias (p. 12)",

Em corroboração com esta linha de pensamento, Denzin \& Lincoln (2006), defendem, além da utilização da multiplicidade de instrumentos, uma coerente triangulação entre os mesmos, permitindo uma ligação coerente entre os métodos utilizados. Segundo o autor, o termo triangulação pode ser compreendido de três maneiras básicas:

Triangulação é um termo muito popular (...) apresentando três significados básicos: (1) triangulação como a validação mútua de resultados obtidos por métodos diferentes, (2) triangulação como um modelo mais abrangente, mais completo para visualização do fenômeno (modelo da complementaridade) e (3) triangulação em seu sentido trigonométrico, indicando uma combinação de métodos para formar um quadro claro de relevância do fenômeno como um todo (DENZIN, 2006, p.7) 
Desta forma, os instrumentos utilizados em uma pesquisa de cunho qualitativo devem ser coerentes com o fato de tal levantamento ter "o ambiente natural como sua fonte direta de dados (LUDKE \& ANDRE, 2008)". A preocupação com o processo que os sujeitos encontram-se submetidos é tão importante quanto o produto final (CARVALHO, 2006). Segundo a autora, “ (...) queremos entender o processo do ensino, entretanto o produto, isto é, a aprendizagem (...) também é importante (...) somente existe ensino se existir aprendizagem (p. 25)".

Para Astolfi (1993), a validade de pesquisas qualitativas relaciona-se diretamente com as múltiplas referências disponíveis e diversidade de rigores. Segundo o autor, deve-se "procurar, ao menos, três fontes de dados que possam oferecer visões distintas do problema de pesquisa (p.5)".

Em corroboração com o embasamento supra descrito, a seguir, apresentaremos os diversos instrumentos utilizados nesta pesquisa de natureza qualitativa que foca a análise de conteúdo, com seu respectivo contexto de utilização.

\subsection{Os Portfólios}

Os portfólios são um conjunto de documentos, organizados em pastas, que os alunos devem entregar ao término da disciplina de "Metodologia do Ensino de Física II’. As citadas documentações não têm um roteiro rigoroso para sua confecção, mas devem conter registros relevantes ocorridos durante a disciplina, tanto em sala de aula como no estágio supervisionado.

Neste caso, minimamente, os portfólios deveriam apresentar, conforme orientação da professora responsável pela disciplina de Metodologia do Ensino de Física II:

- as sínteses produzidas pelos discentes durante a disciplina, as quais contém suas reflexões acerca dos temas tratados, bem como suas relações com os referenciais teóricos apresentados e as vivências constatadas no estágio;

- as sínteses dos textos teóricos estudados na disciplina (ver apêndice).

- relatos de aulas observadas, atividades de participação e outros episódios relevantes ocorridos durante o estágio; 
- o processo de construção do projeto, bem como sua aplicação em ambiente escolar, englobando, de forma detalhada, as etapas passadas pelo estagiário durante tal elaboração, o delineamento de cada aula ministrada, bem como a metodologia de pesquisa utilizada;

- a avaliação final (síntese da disciplina), onde o licenciando emitirá juízos a respeito de sua evolução no decorrer do processo de aprendizagem, bem como da criação e aplicação de seu projeto em ambiente escolar.

A confecção do portfólio toma papel fundamental para posteriores análises, pois, como aponta Ludke \& André (1994):

"Embora pouco explorada não só na área de educação como em outras áreas de ação social, a análise documental pode se constituir numa técnica valiosa de abordagem de dados qualitativos, seja complementando as informações obtidas por outras técnicas, seja desvelando aspectos novos de um tema ou problema (p.38)"

Salientamos também, neste caso particular, a posição de Erickson (1998), que considera "a utilização da produção escrita dos próprios alunos [estagiários, no caso da pesquisa em tela] como um aumento da credibilidade da análise (p.32)”.

Desta forma, a análise do portfólio procurará abarcar informações relevantes no tocante à evolução do estagiário, mas, principalmente, no que diz respeito à confecção de seu projeto de estágio, onde, concentra-se, em grande parte, uma primeira elaboração de um possível conhecimento pedagógico de conteúdo - momento onde o licenciando deverá escolher (e justificar) um tema de sua área ou interdisciplinar, modificá-lo de forma elaborativa, adaptando-o a um contexto escolar para posterior apropriação dos alunos e da escola, onde o estágio é desenvolvido.

\subsection{Gravações das Aulas de "Metodologia do Ensino de Física II"}

A disciplina "Metodologia do Ensino de Física II" apresentava uma carga horária semanal de 4h/aula, totalizando 15 aulas no decorrer do $2^{\circ}$ semestre de 2012. Todo este período, com autorização prévia dos discentes, foi gravado na forma de vídeo, 
sendo registrados todos os momentos de explanação da professora responsável, discussão das atividades propostas, socialização das conclusões dos estudantes, entre outras ocorrências. Salientamos que os sujeitos da pesquisa desta disciplina, R, C, A, L e W, freqüentaram regularmente tais aulas, o que nos permite analisar suas intervenções, procedimentos e atitudes durante estes momentos.

Em relação à utilização do vídeo, salientamos que, segundo Pereira (2008), a vídeo-gravação é um instrumento fundamental, que possibilita o registro de acontecimentos fugazes e não repetíveis, que, provavelmente, escapariam à observação direta. Desta forma, uma análise posterior do vídeo, permitiria uma interpretação mais isenta e longe da carga emotiva que caracteriza a situação original. Para Ludke \& Andre (2008), o planejamento nas filmagens é essencial, pois para que o vídeo se torne um instrumento válido e fidedigno, a observação precisa ser controlada e sistemática (p.25).

\subsection{Gravações das Supervisões da disciplina "Metodologia do Ensino de Física II"}

Durante o decorrer da disciplina "Metodologia do Ensino de Física II", os alunos freqüentavam as reuniões de supervisão, que foram, integralmente, gravadas em vídeo, mediante autorização dos discentes envolvidos. Conforme já descrito no item 1.6, a supervisão coordenada por este pesquisador apresentava sete alunos, totalizando três grupos de estágio, dos quais apenas os relatos documentados dos grupos compostos, respectivamente, pelos sujeitos R e C (Grupo I) e A, L e W (Grupo II) serão considerados nesta análise, procurando, desta forma, um maior aprofundamento nos episódios de ensino surgidos.

No ambiente da Supervisão, os futuros professores, durante as discussões e reflexões sobre os referenciais teóricos, práticas em sala de aula e vivências no estágio, iniciavam a elaboração das intervenções pedagógicas que buscassem a inserção de um tema sobre física com as turmas onde o estágio era realizado. Mesmo após a construção deste processo de criação do projeto de estágio por parte dos licenciandos, acompanhamos, através de seus relatos, suas aplicações em ambiente escolar. Tal momento da pesquisa apresentou o intuito de acompanhar os imprevistos com que os estagiários se depararam em sala de aula, mesmo com um planejamento previamente definido, o que os obrigava a criar e inovar em um curtíssimo espaço de tempo para dar 
continuidade ao processo. Esta etapa, de acordo com nossa visão, é parte integrante da elaboração de um conhecimento pedagógico de conteúdo por parte do docente, haja vista a necessidade deste recorrer a seu próprio repertório criativo para estabelecer rapidamente novas relações com o conteúdo e suas inserções no ambiente educacional.

\subsection{Registros de Campo}

Durante todo o processo da tomada de dados, o pesquisador efetuou registros em seu caderno de campo, os quais, de acordo com sua relevância para o tema abordado, podem auxiliar, devidamente identificados, o corpo de dados desta pesquisa.

\subsection{As Entrevistas Finais}

Segundo Bogdan \& Biklen (1994), as entrevistas permitem que o investigador capte o discurso do próprio sujeito para que, deste modo, a análise possa se tornar evidente.

Desta forma, ao término da disciplina, procuramos, a título de aprofundamento das informações sobre a aprendizagem dos licenciandos durante o estágio, bem como dos aspectos relacionados à criação de seus Conhecimentos Pedagógicos de Conteúdo, a realização uma entrevista final, em caráter semi-estruturado, com os sujeitos de pesquisa desta disciplina.

Ainda segundo Bogdan \& Biklen (op. cit.), as entrevistas semi-estruturadas são, fundamentalmente, constituídas por questões indiretas e não específicas, que ao tornarem o objetivo de determinadas questões menos óbvio, possibilita a abordagem indireta, com maior probabilidade de produzir respostas francas e abertas. Tal entrevista, em nossa pesquisa, apresentou como orientação o roteiro a seguir: 


\section{Roteiro da Entrevista:}

1) Você poderia falar seu nome, idade e experiência docente?

2) Como era a escola que você estagiou? (Pública ou Particular? Tradicional ou Alternativa? Recepção dos professores equipe gestora e alunos a sua presença, etc)

3) Fale-me um pouco sobre o seu estágio. Você acha que o estágio contribuiu para a sua formação como professor?Em que aspectos?Que experiências esse estágio the proporcionou?

4) Qual era o seu objetivo inicialmente previsto no seu plano de estágio? Você considera que o atingiu? Por quê?

5) Que conteúdo você optou por utilizar em seu estágio? Por que a escolha desse conteúdo?

6) Tem alguma particularidade que seja necessário saber para o ensino desse conteúdo?

7) Que estratégias você utilizou para abordar esse conteúdo? Por quê?

8) De onde veio a ideia para abordar o conteúdo desta forma?

9) Onde você buscou informações para o seu projeto de estágio? Utilizou textos didáticos ou textos acadêmicos?

10) Como era o ambiente (a relação entre os alunos, os professores e o grupo gestor) escolar? Os alunos eram participativos? Você considerou isso em seu planejamento?

11) O que você achou da reação dos alunos durante a aplicação de seu projeto de estágio?

12) Durante a aplicação ocorreu algum imprevisto que o obrigou a "alterar o rumo" do planejamento inicial? O que você fez e como você se sentiu nesse caso?

13) Após a aplicação, você faria algo diferente ao abordar esse conteúdo novamente?

14) Se fosse comentar essa sua experiência docente com outro professor, o que você considera relevante contar? Por quê?

15) Você conversou com alguém sobre o seu projeto de estágio? Eles gostaram? Houve críticas ou sugestões a ele que você acatou?

16) $\mathrm{O}$ que você julga importante um professor de física saber para poder ensinar? Basta saber o conteúdo a ser ensinado? Por quê?

17) Você já tinha participado de alguma experiência como a supervisão? Considera que ela contribuiu de alguma forma para o seu estágio? Por quê? 
A formulação dos questionamentos anteriores, visando à construção final da entrevista, foi realizada, em conjunto, por este pesquisador, a professora da disciplina de Metodologia de Ensino de Física II e o monitor responsável pelos demais grupos de supervisão. A configuração final obtida da entrevista visava a abranger a maior gama possível de fatores relativos ao processo analisado.

Desta forma, procurou-se abarcar as etapas de criação e recriação de elementos dos Conhecimentos Pedagógicos de Conteúdo (dimensões de conteúdo, contexto e pedagógicos, cf. Shulman, (1987)) e sua construção durante o processo de pesquisa realizado pelos estagiários, a relação entre estes e o processo de estágio investigativo proposto, além das possíveis reflexões surgidas durante e após as etapas já descritas da disciplina.

Salientamos que, os demais questionamentos da entrevista formulada, visavam a um delineamento mais preciso de demais aspectos relativos à formação e aprendizagem docente, que contribuem, em um aspecto geral para a contextualização da pesquisa em tela.

A seguir, procuramos expor, na forma de um quadro, a relação entre as perguntas formuladas e o elemento principal relativo à formação docente e/ou sua criatividade na elaboração de conhecimentos que procurou ser observado. 


\section{SÍNTESE DOS ELEMENTOS ANALISADOS NA ENTREVISTA}

\begin{tabular}{|c|c|c|}
\hline $\begin{array}{c}\text { Elemento a ser } \\
\text { observado }\end{array}$ & $\begin{array}{c}\text { Detalhamento do } \\
\text { elemento a ser observado }\end{array}$ & Perguntas \\
\hline \multirow[b]{2}{*}{ Contexto } & $\begin{array}{l}\text { Experiência Docente do } \\
\text { Licenciando }\end{array}$ & $\begin{array}{l}\text { - Você poderia falar seu nome, idade e } \\
\text { experiência docente? }\end{array}$ \\
\hline & Escola que Estagiou & $\begin{array}{l}\text { - Como era a escola que você estagiou? } \\
\text { (Pública ou Particular? Tradicional ou } \\
\text { Alternativa? Recepção dos professores } \\
\text { equipe gestora e alunos a sua presença, etc) }\end{array}$ \\
\hline \multirow[b]{2}{*}{ Criação } & Criação no Planejamento & $\begin{array}{c}\text { - De onde veio a ideia para abordar o } \\
\text { conteúdo desta forma? }\end{array}$ \\
\hline & Criação na prática & $\begin{array}{c}\text {-Durante a aplicação ocorreu algum } \\
\text { imprevisto que o obrigou a "alterar o } \\
\text { rumo" do planejamento inicial? O que } \\
\text { você fez e como você se sentiu nesse caso? }\end{array}$ \\
\hline \multirow{4}{*}{ PCK } & $\begin{array}{l}\text { Conhecimento/Saber do } \\
\text { Conteúdo }\end{array}$ & $\begin{array}{l}\text { - Que conteúdo você optou por utilizar em } \\
\text { seu estágio? } \\
\text { - Por que a escolha desse conteúdo? }\end{array}$ \\
\hline & $\begin{array}{l}\text { Conhecimento/Saber } \\
\text { Pedagógico }\end{array}$ & $\begin{array}{l}\text { - Que estratégias você utilizou para } \\
\text { abordar esse conteúdo? Por quê? }\end{array}$ \\
\hline & $\begin{array}{l}\text { Conhecimento/Saber do } \\
\text { Contexto }\end{array}$ & $\begin{array}{c}\text { - Como era o ambiente (a relação entre os } \\
\text { alunos, os professores e o grupo gestor) } \\
\text { escolar? (parecida com parte da "Escola } \\
\text { que Estagiou") } \\
\text { - Os alunos eram participativos? Você } \\
\text { considerou isso em seu planejamento? }\end{array}$ \\
\hline & $\begin{array}{l}\text { Conhecimento/Saber } \\
\text { Pedagógico do Conteúdo }\end{array}$ & $\begin{array}{c}\text { - Tem alguma particularidade que seja } \\
\text { necessária saber para o ensino desse } \\
\text { conteúdo? }\end{array}$ \\
\hline \multirow{2}{*}{ Saberes Docentes } & \multirow{2}{*}{ Geral } & $\begin{array}{l}\text { - O que você julga importante um } \\
\text { professor de física saber para poder } \\
\text { ensinar? Basta saber o conteúdo a ser } \\
\text { ensinado? Por quê? }\end{array}$ \\
\hline & & $\begin{array}{l}\text { - Se fosse comentar essa sua experiência } \\
\text { docente com outro professor, o que você } \\
\text { considera relevante contar? Por quê? }\end{array}$ \\
\hline
\end{tabular}




\begin{tabular}{|c|c|c|}
\hline \multirow{5}{*}{$\begin{array}{c}\text { Estágio } \\
\text { Investigativo }\end{array}$} & $\begin{array}{c}\text { Revisão de Ideias, Práticas } \\
\text { e Atitudes }\end{array}$ & $\begin{array}{c}\text { - Após a aplicação, você faria algo } \\
\text { diferente ao abordar esse conteúdo } \\
\text { novamente? } \\
\text { - Qual era o seu objetivo inicialmente } \\
\text { previsto no seu plano de estágio? Você } \\
\text { considera que os atingiu? Por quê? }\end{array}$ \\
\hline & $\begin{array}{l}\text { Relação Teoria-Prática } \\
\text { significativa para o } \\
\text { estagiário }\end{array}$ & $\begin{array}{l}\text { - Onde você buscou informações para o } \\
\text { seu projeto de estágio? Utilizou textos } \\
\text { didáticos ou textos acadêmicos? }\end{array}$ \\
\hline & $\begin{array}{c}\text { Cooperação e Negociação } \\
\text { de Pontos de Vista }\end{array}$ & $\begin{array}{c}\text { - Você conversou com alguém sobre o seu } \\
\text { projeto de estágio? Eles gostaram? Houve } \\
\text { críticas ou sugestões a ele que você } \\
\text { acatou? }\end{array}$ \\
\hline & $\begin{array}{l}\text { Construção de } \\
\text { Conhecimento sobre a } \\
\text { Prática Docente }\end{array}$ & $\begin{array}{c}\text { - Você acha que o estágio contribuiu para a } \\
\text { sua formação como professor? Em que } \\
\text { aspectos? } \\
\text { - Que experiências esse estágio lhe } \\
\text { proporcionou? }\end{array}$ \\
\hline & Supervisão & $\begin{array}{l}\text { - Você já tinha participado de alguma } \\
\text { experiência como a supervisão? Considera } \\
\text { que ela contribuiu de alguma forma para o } \\
\text { seu estágio? Por quê? }\end{array}$ \\
\hline \multirow[b]{2}{*}{$\begin{array}{l}\text { As criações } \\
\text { durante a prática e } \\
\text { suas recriações }\end{array}$} & Criação na Prática & $\begin{array}{l}\text { - Durante a aplicação ocorreu algum } \\
\text { imprevisto que o obrigou a "alterar o } \\
\text { rumo" do planejamento inicial? O que } \\
\text { você fez e como você se sentiu nesse caso? }\end{array}$ \\
\hline & Recriação & $\begin{array}{l}\text { - O que você achou da reação dos alunos } \\
\text { durante a aplicação de seu projeto de } \\
\text { estágio? Por quê? } \\
\text {-Após a aplicação, você faria algo } \\
\text { diferente ao abordar esse conteúdo } \\
\text { novamente? }\end{array}$ \\
\hline
\end{tabular}

Tabela 4 - Quadro-síntese relacionando as perguntas da entrevista final e os elementos teóricos que procuraram ser observados a partir delas. 
A seguir, procuramos expor um quadro, a título de síntese, dos instrumentos de pesquisa utilizados neste trabalho, bem como um resumo de suas utilizações, sujeitos envolvidos e relevância, além do momento onde foram aplicados.

\section{SÍNTESE DOS INSTRUMENTOS DE PESQUISA UTILIZADOS}

\begin{tabular}{|c|c|c|c|c|}
\hline Instrumento Utilizado & Momento da Utilização & Motivos da utilização & $\begin{array}{l}\text { Sujeitos } \\
\text { Envolvidos }\end{array}$ & Forma de Registro \\
\hline Portfólios & $\begin{array}{l}\text { Entrega definitiva após o } \\
\text { término da Disciplina de } \\
\text { "Metodologia do Ensino } \\
\text { de Física II" (2012). }\end{array}$ & $\begin{array}{l}\text { Através de análise } \\
\text { documental, procurar um } \\
\text { primeiro delineamento } \\
\text { dos processos de criação e } \\
\text { desenvolvimento do } \\
\text { projeto de estágio por } \\
\text { parte dos licenciandos. }\end{array}$ & $\begin{array}{c}\text { R e C (Grupo I) e } \\
\text { W, A e L (Grupo } \\
\text { II) }\end{array}$ & Análise Documental \\
\hline Entrevistas & $\begin{array}{l}\text { Após o término da } \\
\text { disciplina "Metodologia } \\
\text { do Ensino de Física II } \\
\text { (Novembro/ 2012) }\end{array}$ & $\begin{array}{l}\text { Aprofundamento das } \\
\text { informações parciais já } \\
\text { contidas nos portfólios, } \\
\text { procurando caracterizar - } \\
\text { os processos criativos } \\
\text { envolvidos na elaboração } \\
\text { do projeto da disciplina; } \\
\text { - o aprofundamento das } \\
\text { informações sobre a } \\
\text { aprendizagem docente dos } \\
\text { licenciandos durante o } \\
\text { estágio; de as } \\
\text { - aspectos relacionados à } \\
\text { criação de seus } \\
\text { Conhecimentos } \\
\text { Pedagógicos de Conteúdo }\end{array}$ & $\begin{array}{c}\text { R e C (Grupo I) } \\
\text { W, A, L (Grupo II) }\end{array}$ & Áudio e Vídeo \\
\hline Gravação das Aulas & $\begin{array}{l}\text { Gravação das aulas da } \\
\text { disciplina "Metodologia } \\
\text { do Ensino de Física II", } \\
\text { ocorrida no } 2^{\circ} \text { semestre de } \\
2012 \text {. }\end{array}$ & $\begin{array}{l}\text { Caracterizar os relatos, } \\
\text { discussões e socializações } \\
\text { de conclusões por parte } \\
\text { dos discentes da } \\
\text { disciplina. }\end{array}$ & $\begin{array}{l}\text { R e C (Grupo I) } \\
\text { W, A e L (Grupo } \\
\text { II) }\end{array}$ & Vídeo \\
\hline
\end{tabular}




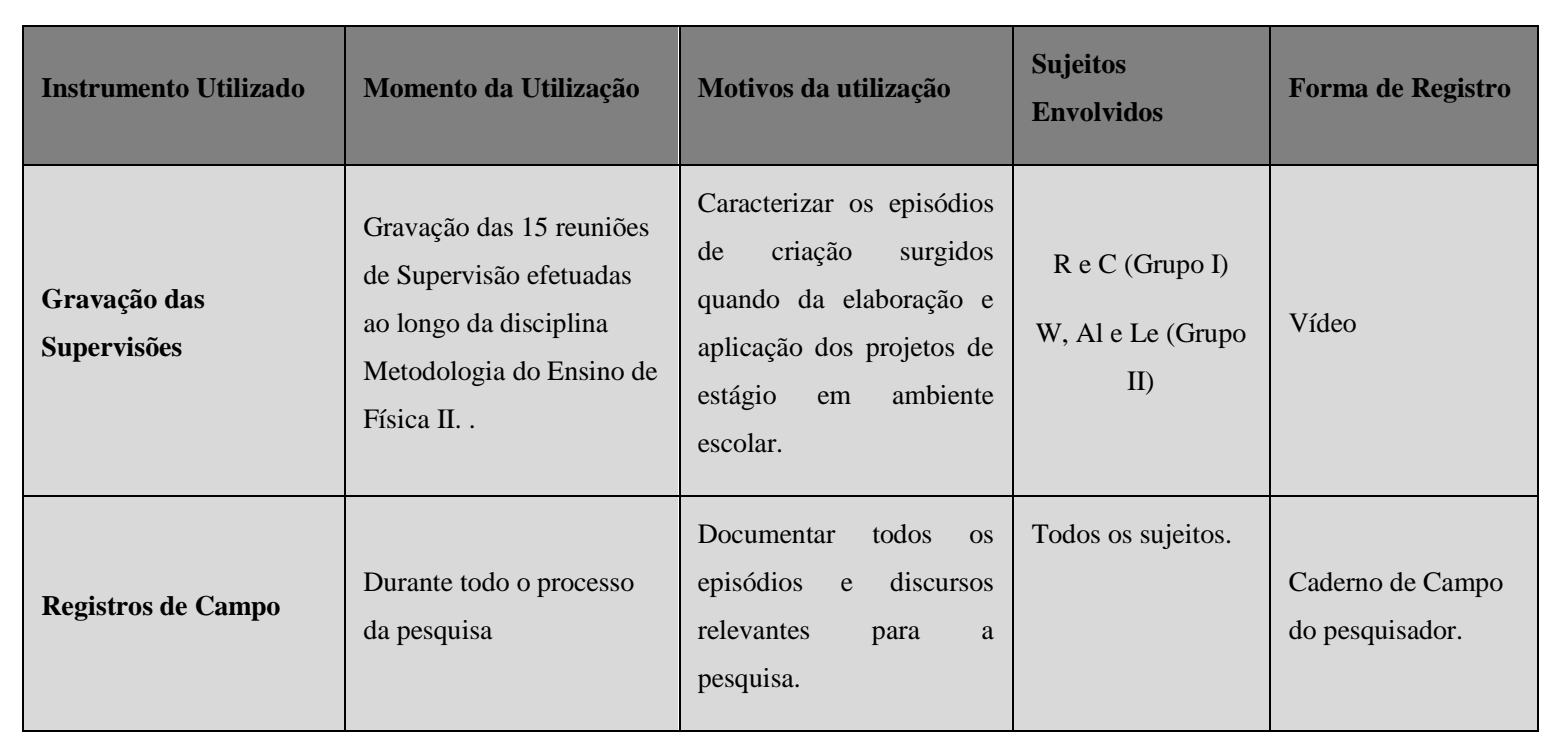

Tabela 5 - Quadro-resumo dos instrumentos utilizados na pesquisa

A análise em conjunto dos múltiplos instrumentos citados anteriormente neste capítulo, apresentam, como aproximação inicial, a localização de situações de interesse acadêmico, ou seja, relatos dos estagiários relacionados com o problema de pesquisa deste trabalho. Tais momentos extraídos dos dados obtidos, onde fica evidente uma situação que queremos investigar, foi definido por Carvalho (2003) como Episódios de Ensino.

No capítulo seguinte, abordaremos a análise dos resultados obtidos através dos instrumentos citados anteriormente e dos episódios de ensino surgidos. 


\section{CAPÍtulo V}

\section{APRESENTAÇÃO E ANÁLISE DOS RESULTADOS}


Neste capítulo, pretendemos expor a análise dos dados obtidos no trabalho de campo, interpretando-os à luz dos referenciais teóricos abordados na pesquisa. Voltamos a salientar que tais resultados são advindos de um estudo qualitativo realizado com licenciandos em Física que cursavam a disciplina "Metodologia do Ensino de Física II" oferecida pela Faculdade de Educação da Universidade de São Paulo durante o $2^{\circ}$ semestre de 2012 e encontravam-se no processo de estágio.

\section{Aspectos Gerais e Objetivos}

Conforme procuramos expor nos capítulos anteriores, o processo criativo é uma ação exclusivamente humana (PIAGET, 1972 e VIGOTSKY, 2009), onde o indivíduo, mediante uma ligação entre pensamento, imaginário e linguagem, elabora novas ideias em seu cotidiano. O processo criativo, em uma primeira análise, surgiria da dinâmica do desequilíbrio contínuo, que, através da tensão e da autorregulação, leva o ser humano a criar. Tal processo, apoiado na linha piagetiana de equilibração majorante, parte do princípio de que as estruturas mentais internas apresentam uma tendência natural em tentar novos equilíbrios sempre que um fato novo interage com o sistema, podendo gerar uma acomodação ou assimilação pelo sistema cognitivo com o fato desequilibrador. No tocante à criação de uma ideia genuinamente nova, Vasconcelos (2001), esclarece que, além da adaptação entre o sujeito e o objeto por meio dos processos adaptativos, o fato exige uma reflexão profunda em um nível mais elevado, denominado por Piaget como abstração reflexiva.

Ainda no tocante ao referencial piagetiano, conforme já exposto no capítulo III deste trabalho, não menos importante são as condutas que permitem ao indivíduo tomar conhecimento dos elementos novos - as perturbações. Para Piaget (2002), tais perturbações podem levar o indivíduo a agir sobre o meio externo de duas formas distintas: a) as lacunas, quando o sujeito não apresenta, naquele momento, condições de compreensão do fator desequilibrador e b) a tentativa de incorporação da instabilidade em seus sistemas cognitivos.

Considerando-se a existência de elementos mentais que sejam capazes de abrigar tais situações perturbadoras, Piaget expõe a possibilidade de três condutas por parte do sujeito, sendo elas 1) a conduta alfa, que consiste em ensaios de neutralização da perturbação, suprimindo-a ou, simplesmente, negando-a em "uma espécie de ignorância 
voluntária (MACEDO, 2009)"; 2) a conduta beta, representada por situações onde o sujeito procura deslocamentos de equilíbrio do sistema mental inicial, incorporando tal situação em esquemas cognitivos já existentes e organizados mediante o processo de assimilação; 3) conduta gama, caracterizada pela incorporação da perturbação no próprio sistema mental do estagiário, causando conflitos nos esquemas previamente estruturados, resultando em um novo equilíbrio, mais estável que o anterior, com a ampliação dos esquemas anteriores.

Apesar deste esquema aparentemente completo para o estudo das criações humanas, Piaget, em sua teoria de equilibração genética, não coloca em destaque alguns aspectos fundamentais, também necessários para a compreensão do processo criativo, como o contexto cultural onde o indivíduo se encontra inserido (STOLTZ, 1999 e DE LA TORRE, 1996, p.e.).

Apesar das linhas de estudos piagetianos mais recentes incorporarem os fatores sociais em suas análises, através dos conflitos de natureza sociocognitivos (CASTORINA, 2008), em nosso ponto de vista, essa nova visão social ainda se limita aos fatores mais diretamente próximos do indivíduo, em sua sala de aula, no contato direto com seus pares, por exemplo. A cultura, juntamente com a sociedade onde o ser humano vive, traz fundamentais influências para o desenvolvimento da criatividade, haja vista o indivíduo ser um ente socialmente e historicamente construído, sofrendo as pressões, tensões e apoios que estes contextos produzem.

Nesta linha, os elementos da psicologia vigotskiana são inseridos em nosso quadro teórico, estabelecendo o processo criativo em um patamar social, ou seja, com forte impacto da cultura vigente. Desta forma, pretendemos tratar a criação humana como uma atividade em seu sentido mais estrito dado pela escola de Vigotsky, onde o genuíno processo criativo deve ser movido por um motivo/necessidade legítimo, ou seja, conscientemente elaborado, apresentando como finalidade o objetivo inicial gerador, que no caso da formação docente, em nossa visão, tratar-se-ia da melhor aprendizagem por parte dos alunos. As formas de alcançar este objetivo podem estar descritas nos diversos conhecimentos pedagógicos de conteúdos a serem desenvolvidos pelo professor para alcançar esta meta.

Diante deste quadro, procuramos analisar a formação docente neste processo, ou seja, procuramos compreender a criatividade como mais uma característica dos 
considerados bons professores (SILVA, 2005), estabelecendo sua dinâmica na elaboração de conhecimentos pedagógicos de conteúdos (SHULMAN, 1987), vital para o processo de desenvolvimento profissional, em nossa visão. Diante disso, tratamos a criatividade como um elemento inerente ao raciocínio pedagógico (SHULMAN, op.cit.), podendo, portanto, ser caracterizado e desenvolvido pelo docente em sua formação.

No tocante à tomada de dados, esclarecemos que, devido à natureza da metodologia utilizada, bem como o contexto da pesquisa, já explorado no capítulo anterior, a maior parte das informações obtidas refere-se a diálogos ocorridos entre os próprios integrantes dos grupos de trabalho do estágio, fato este que, em alguns momentos da análise, não nos fornece elementos suficientes para individualizar os caminhos criativos, tampouco os conhecimentos pedagógicos de conteúdo elaborados. Portanto, a análise de dados que segue tem a peculiaridade de tratar, sempre que necessário, esses processos de maneira coletiva, considerando-os como uma construção do grupo de estagiários.

Tão importante quanto ao aspecto coletivo, é a exposição, a título de orientação, dos elementos referentes aos Conhecimentos Pedagógicos de Conteúdo que serão considerados nessa pesquisa, enfatizando, novamente, a limitação metodológica para sua profunda caracterização, buscando salientar, portanto, os principais componentes que influenciaram sua elaboração.

O estudo do Conhecimento Pedagógico de Conteúdo (PCK) se demonstrou, na revisão histórica realizada no capítulo II, uma complexa rede de conceitos e termos utilizados por diversos autores em períodos e contextos diferentes.

Shulman (1986), em seu primeiro estudo, estabelece que

Dentro da categoria de conhecimento pedagógico de conteúdo eu incluo, para a maioria dos tópicos regularmente ensinados de uma área específica de conhecimentos, as representações mais úteis de tais ideias, as analogias mais poderosas, ilustrações, exemplos, explanações e demonstrações (...) também inclui uma compreensão do que torna a aprendizagem de tópicos específicos fácil ou difícil: as concepções e pré-concepções que estudantes de diferentes 
idades e repertórios trazem para as situações de aprendizagem (p.9).

Desse modo, fica visível a importância atribuída pelo autor aos elementos específicos relacionados ao conteúdo ("tópicos regularmente ensinados de uma área específica de conhecimentos”), à questão pedagógica ("as representações mais úteis de tais ideias, as analogias mais poderosas, ilustrações, exemplos, explanações $e$ demonstrações") e uma preocupação com um elemento de contexto fundamental ("as concepções e pré-concepções que estudantes de diferentes idades e repertórios trazem para as situações de aprendizagem”). Ainda para esse autor, o PCK "é definido como um caminho único para os professores no que diz respeito ao conteúdo e suas transformações em instrução, para que os alunos possam compreender (grifo nosso)".

Em versões mais atuais dessa linha de pensamento (SHULMAN \& SHULMAN, 2004), percebe-se uma maior preocupação com as questões relativas ao contexto da aprendizagem (discente e docente), fazendo com que sejam estabelecidas comunidades com elementos específicos onde o professor desenvolve sua própria aprendizagem, contexto este, capaz de desenvolver novas visões de ensino ao docente.

Entretanto, de modo geral, e em corroboração com Ball (2008), o tratamento do Conhecimento Pedagógico de Conteúdo como sendo um caminho único para o estabelecimento do desenvolvimento do professor com relação ao ensino de um tópico específico não é sustentado nesse trabalho, que defende a tese de que a criatividade pode ser desenvolvida em diversos momentos da trajetória docente, sendo fundamental para o amadurecimento e alterações do PCK, bem como para organização dos processos de formação, sempre quando este modelo se demonstrar incapaz de solucionar novas situações de instabilidade que permeiam a carreira do magistério.

Assim, em convergência com nosso referencial teórico, nos aproximamos dos modelos de PCK elaborados por Cochran (1993), que, em uma linha mais próxima do construtivismo, nos insere o PCKg, utilizado a denominação knowing (conhecendo, em inglês), para referir-se à natureza dinâmica do desenvolvimento dos saberes docentes no decorrer de sua carreira.

Na continuidade de uma busca de coerência com os referenciais relativos ao desenvolvimento criativo, optamos também pela proposta estabelecida por Grossman (1990), que estabelece três componentes mais gerais e fundamentais ao 
desenvolvimento de novos Conhecimentos Pedagógicos de Conteúdo: o Conhecimento do Conteúdo, o Conhecimento Pedagógico Geral e o Conhecimento do Contexto. Tais formas de Conhecimentos docentes acabam pela geração de novos PCK, que também buscarão a utilização das concepções prévias dos estudantes, o conhecimento do currículo e de estratégias de ensino, conforme ilustrado no esquema abaixo:

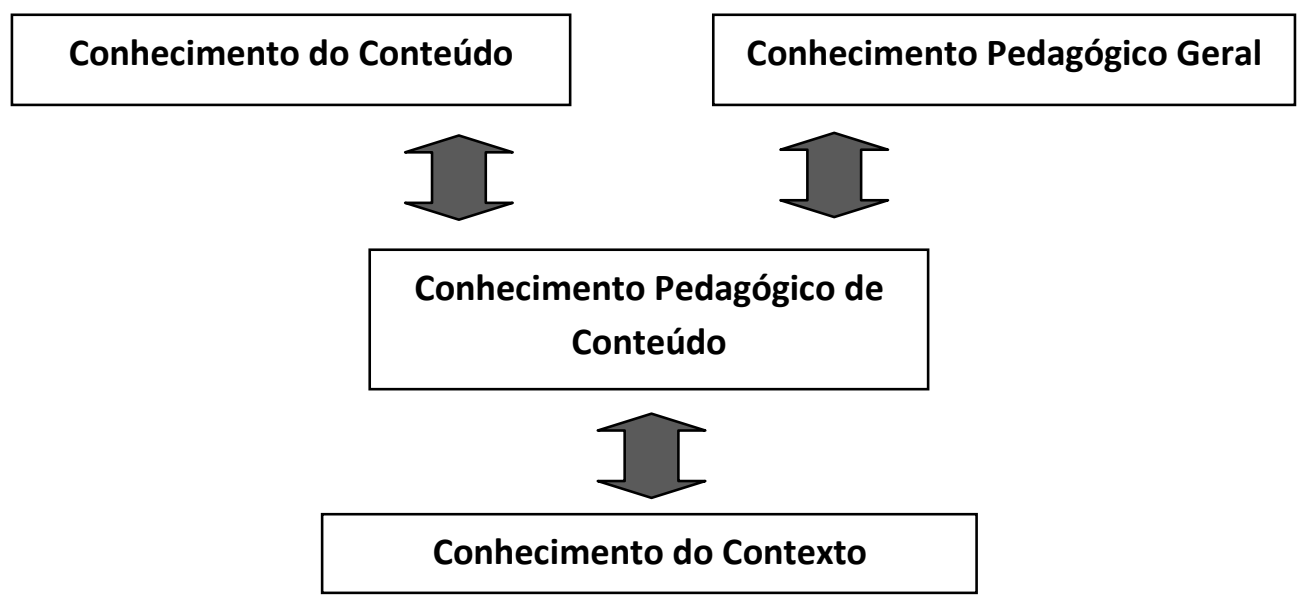

Esquema 1 - Modelo de PCK utilizado (adaptado de Grossman (1990).

Além da utilização dos elementos fundamentais citados anteriormente, também buscamos, como já citado neste trabalho, a classificação da interação criada de acordo com os patamares integrativo e transformativo proposto por Gess-Newsome (1999). Nesse ponto, vale salientar que, para a autora, no patamar integrativo, o PCK elaborado não é considerado um novo conhecimento, mas uma soma dos componentes relativos ao conteúdo, pedagogia e contexto.

Novamente, esclarecemos que, nesse trabalho, utilizaremos uma visão particular de possíveis PCK gerados em patamares integrativos, considerando-o sim, como um novo conhecimento, haja vista que, em nosso ponto de vista, este será fruto de articulações entre elementos mais gerais, relativos ao contexto, conteúdo ou pedagógico, participando, portanto da integração do sistema de repertórios docentes (PIAGET, 1972 e VIGOTSKY, 2009), ampliando-o e possibilitando o desenvolvimento de novos saberes. A seguir, propomos uma adaptação do esquema de Gess-Newsome (1999), apresentando o PCK integrativo como uma rede de articulações, citada anteriormente. 


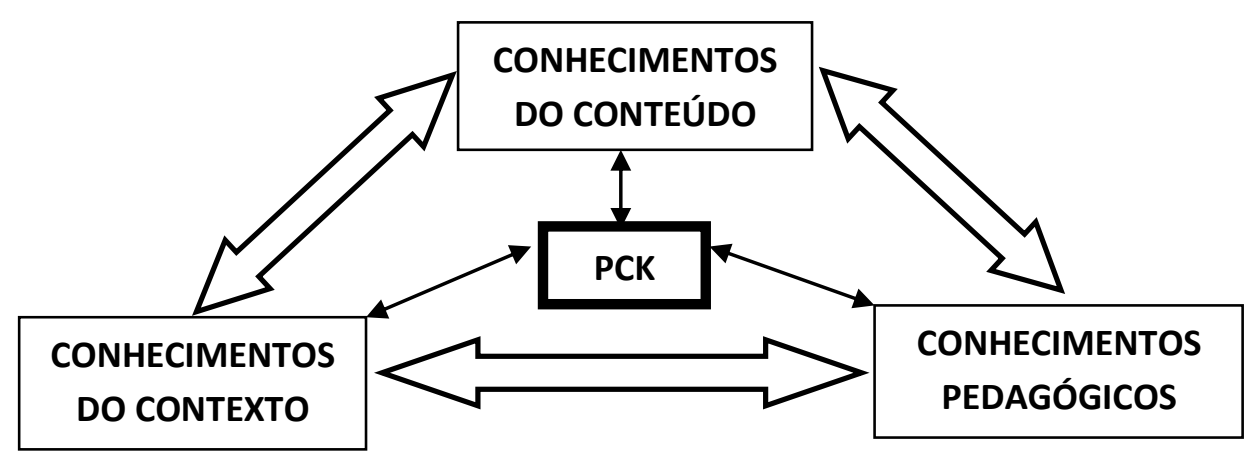

Esquema 2 - Visão de PCK Integrativo adotado nesse trabalho

Portanto, na análise que segue, procuramos tratar os Conhecimentos Pedagógicos de Conteúdo como um instrumento de análise, elencando, com base nos componentes propostos por Grossman (op.cit.) - Conteúdo, Pedagógico e Contexto possíveis fatores influenciadores ao desenvolvimento de PCK dos futuros professores de Física, quando confrontados com situações inéditas e geradoras de instabilidade durante sua prática.

Salientamos, também que, face ao número de instrumentos utilizados nesta pesquisa, identificaremos a origem da extração dos trechos expostos de acordo com os símbolos abaixo:

Ent - episódio retirado de entrevista concedida pelo licenciando;

Port - trecho extraído do portfólio do estagiário;

Sup - fala transcrita da reunião de supervisão.

Aula - cena selecionada da aula de Metodologia do Ensino de Física II

Visando a uma melhor compreensão dos resultados apresentados, esclarecemos que todas as declarações contidas em entrevistas e reuniões de supervisão encontram-se devidamente transcritas e expostas nos anexos deste trabalho. No caso particular dos trechos extraídos das reuniões de supervisão, utilizaremos, no início dos mesmos, durante este capítulo, um código numérico, sendo que o primeiro algarismo representa o número de ordem da reunião efetuada, enquanto que os demais números indicarão o instante, em minutos e segundos, da ocorrência da fala transcrita naquele encontro. Ilustrativamente, apresentamos, a seguir, um modelo da forma como os episódios de interesse acadêmico serão apresentados: 


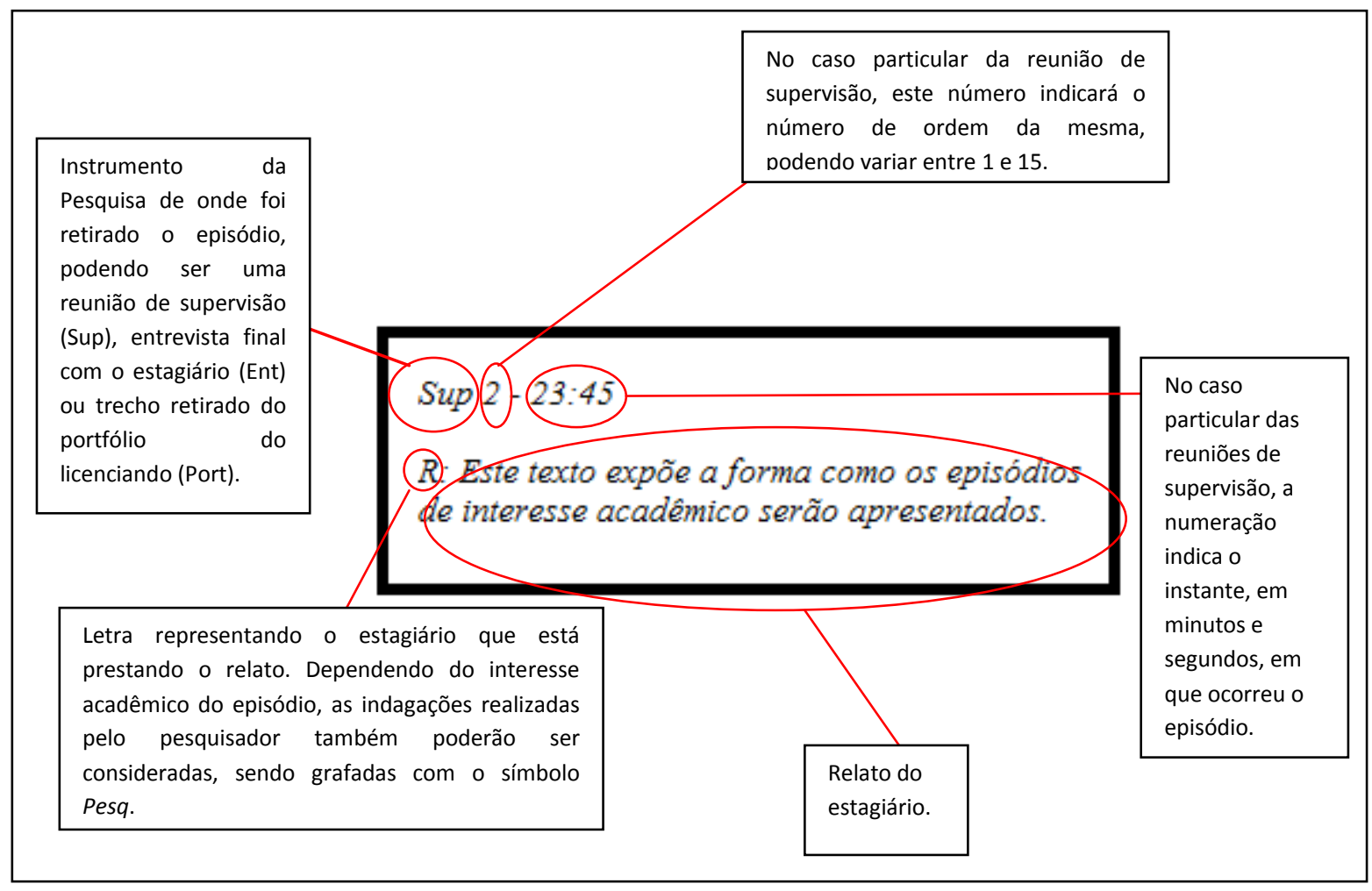

Fig. 8 - Modelo de episódio de interesse acadêmico

Salientamos que, com o intuito de manter o texto em um padrão dinâmico e acadêmico, optamos por realizar pequenas alterações nas falas dos estagiários no tocante à correção gramatical e semântica, que pudessem permitir uma contextualização mais eficaz do contexto das situações ocorridas, não interferindo, entretanto, no teor do discurso apresentado, no que se refere aos fenômenos aqui em análise.

A seguir, exporemos, além dos instrumentos utilizados já descritos no capítulo anteriores, com os respectivos resultados obtidos após sua aplicação, uma abordagem dos principais elementos, de acordo com nosso alicerce teórico, necessários à compreensão da dinâmica dos processos criativos docentes.

\section{Os Elementos Inerentes ao Processo de Criação dos Estagiários: Os Caminhos Criativos Docentes}

De acordo com Vigotsky (2009), as atividades criadoras poderiam ser divididas em dois níveis básicos, conforme o ineditismo da criação elaborada pelo sujeito. Desta forma, são apresentadas as intervenções reprodutivas, onde o principal objetivo é a repetição de meios e condutas anteriormente criadas, ressuscitando marcas ou impressões precedentes, e as intervenções criadoras ou combinadoras, onde os 
elementos de experiências anteriores são combinados, adaptados e reelaborados em novas situações ou comportamentos.

A criação de elementos por parte dos estagiários da licenciatura em Física, seja quando do planejamento de suas atividades, bem como durante sua prática em sala de aula, retrata o inevitável contato dos licenciandos com os imprevistos que emergem das situações docentes cotidianas, fazendo surgir a possibilidade do mesmo se " adaptar à novidade imposta pelo meio, tal qual o surgimento de um conflito (PIAGET, 2002 e CASTORINA, 2008)", sendo exigida a reestruturação de seus esquemas mentais para a criação de uma nova intervenção ligada à nova situação exposta.

De acordo com os elementos da teoria histórico-cultural (RIGON, 2009), mais precisamente no tocante ao conceito de atividade, proposto inicialmente por Vigotsky (2009), o ato criador, em corroboração com nosso ponto de vista, deve ser, antes de tudo, uma atividade criadora, ou seja, um processo movido por necessidades legítimas que visam a alcançar um objetivo relacionado, que, no caso da profissão docente, seria promover o ensino para a melhor aprendizagem dos alunos.

Juntamente com a necessidade criadora e os conflitos de caráter sociocognitivo (CASTORINA, 2008) que podem dispará-la, encontra-se a ausência de elementos que um futuro professor pode apresentar para a resolução dos imprevistos surgidos - as lacunas - como já tratadas pela Teoria de Equilibração Piagetiana (PIAGET, 2002). A diminuição da possibilidade de ocorrência de lacunas teria o potencial de uma maior colaboração com a atividade criadora docente, haja vista que, para Vigotsky (2009), bem como para o próprio Piaget (1972), o aumento de repertório e experiências vividas proporcionariam maior facilidade ao ato criador, favorecendo o aparecimento de adaptações aos fatos novos surgidos.

Portanto, buscamos neste trabalho a existência de elementos que podem nos trazer indicações e contribuições ao entendimento da dinâmica do processo criativo do futuro professor, tais como seu repertório adquirido até aquele momento, experiências vividas, existência de perturbações e conflitos com potencial para favorecer criações, ou mesmo lacunas que, devidamente inseridas no contexto da trajetória pedagógica, podem gerar necessidades legítimas para que o estagiário busque a criação de novos elementos, favorecendo, assim, a melhora no quadro de aprendizagem discente. 
Além dos elementos já citados, também podemos inserir as necessidades criativas docentes, que surgiram juntamente com a condição de conflito, direcionando o futuro professor para recorrências aos seus repertórios e experiências pessoais, possibilitando ao estagiário a resolução da perturbação inicial, culminando na criação, propriamente dita, de uma nova intervenção pedagógica, que, neste trabalho, é representada por um novo Conhecimento Pedagógico de Conteúdo (Shulman, 1987).

Em face desta gama de fatores, este trabalho, apesar de trazer o referencial teórico vigotskiano como uma de suas principais bases de análise, procura se afastar do caráter dicotômico dado por este autor à variedade das criações humanas, que identificou os níveis reprodutor e combinador, para, respectivamente, criações baseadas estritamente em cópias de outras situações já existentes e reelaborações de situações anteriores que geraram interações originais.

$\mathrm{Na}$ análise que segue, é possível inferir que o processo de criação é por demais complexo, recebendo influência de diversos fatores (como os descritos anteriormente e que serão objeto desta pesquisa). Tal fato nos remete à hipótese de que os níveis reprodutor e combinador propostos por Vigotsky seriam os extremos de um espectro contínuo (Fig.9), estabelecendo-se entre eles diversas situações de criação com mais ou menos características de um dos extremos, porém, alvo de diversos elementos influenciadores, cada um deles com sua parcela específica de contribuição.

Dessa forma, optaremos, não por estratificar a criação dos estagiários em níveis reprodutores ou combinadores, mas analisar os elementos que apresentariam forte influência na criação docente. Dessa maneira, analisaremos as perturbações, repertórios, experiências vividas, conflitos, lacunas e necessidades criativas dos futuros professores, elementos estes que possibilitariam uma melhor interpretação dos trajetos realizados pelos licenciandos quando da elaboração de suas intervenções. Tais trajetos foram denominados neste trabalho como Caminhos Criativos Docentes.

Por outro lado, é neste ponto que voltamos a insistir que, mesmo um nível reprodutor, apesar de relacionar-se, aparentemente e pejorativamente, à cópia de uma experiência já existente, pode sim ser considerado como uma atividade criadora, com necessidade legítima por parte do professor em atingir o mesmo objetivo que gerou tal instabilidade, desde que o leve a uma resolução bem sucedida de imprevistos surgidos durante a prática profissional. Ressaltamos, portanto, que consideraremos, neste 
trabalho, os níveis reprodutor e combinador como extremos de uma distribuição contínua com aumento gradativo de adaptações em relação a um repertório inicial.

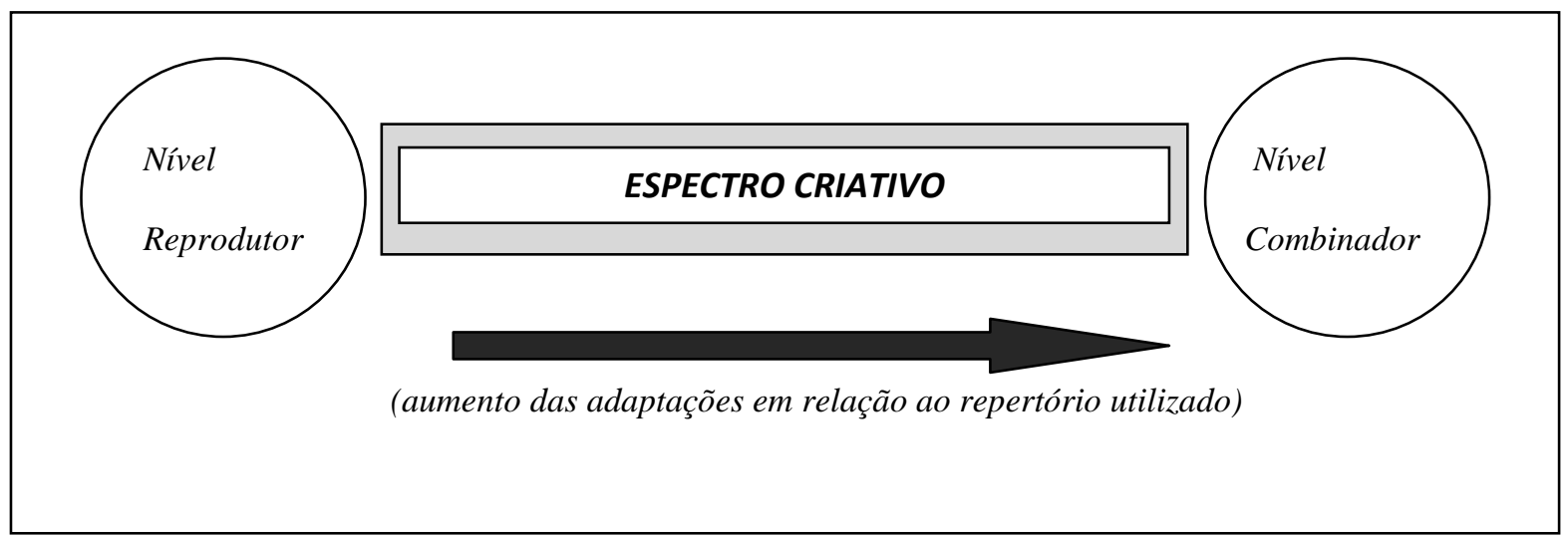

Fig. 9 - Os níveis criativos vigotskianos adaptados para o modelo de Caminhos Criativos

$\mathrm{Na}$ sequência, apresentaremos o processo de apresentação e análise dos resultados, propriamente dito. Para tanto, iniciaremos com uma discussão acerca da proposta de categorização utilizada neste trabalho, que guiará nossas futuras interpretações das intervenções criadas pelos licenciandos.

\section{Proposta de Categorização: as perturbações e condutas piagetianas como eixo da análise}

Conforme exposto anteriormente, pretendemos desenvolver a análise dos resultados obtidos mediante a interpretação de episódios de interesse acadêmico selecionados das transcrições das reuniões de supervisão, entrevistas, registros de portfólios e das aulas da disciplina de Metodologia de Ensino de Física II acompanhadas pelos licenciandos da Universidade de São Paulo.

O início do processo de análise se deu, em um primeiro momento, mediante as transcrições e registros dos diálogos efetuados pelos estagiários, bem como o contexto onde estes ocorriam, configurando, desta forma, os diversos instrumentos de pesquisa utilizados neste trabalho. Em uma segunda etapa, tais registros foram selecionados em episódios que contivessem "elementos fundamentais para o problema de pesquisa que queremos investigar (CARVALHO, 2006)”, configurando, desta forma, os episódios de interesse acadêmico. 
A partir deste ponto, nossa preocupação concentrou-se em alocar tais episódios em situações de características similares, permitindo, portanto, uma categorização destas situações que envolviam o desenvolvimento do processo criativo do futuro professor. Desta forma, em convergência com a Teoria de Equilibração Piagetiana, efetuamos uma subdivisão das situações encontradas de acordo com o fator inicial que as causou - as perturbações advindas da prática cotidiana docente, bem como a conduta deste após a instalação da instabilidade.

Ao estabelecermos que tais situações de instabilidades iniciais e suas condutas serão o eixo norteador de nossa análise, nos apoiamos, inicialmente, na contribuição de Macedo (2009) que, ao rever tais conceitos da teoria de Piaget, expõe que:

$$
\begin{aligned}
& \text {...[para Piaget] existem dois tipos de } \\
& \text { perturbações: 1) as que se opõe às acomodações, } \\
& \text { manisfestando-se por resistências a objetos ou } \\
& \text { obstáculos às assimilações; 2) as que se constituem como } \\
& \text { lacunas, percebidas como ausência de condição que seja } \\
& \text { imprescindível para concluir uma ação (p.308). }
\end{aligned}
$$

Desta forma, podemos considerar o futuro professor como o sujeito imerso em um ambiente (o cotidiano social docente) capaz de fornecer os mais diversos tipos de situações, muitas delas, potenciais causadoras de instabilidades. Tal fato nos permitiu enfocar, também, a psicologia vigotskiana, ao passo que compreendemos as fontes de conflitos e perturbações como o ambiente social e cultural onde o futuro docente está inserido. Em nosso ponto de vista, tais situações podem se caracterizar por condutas do estagiário em relação às ações tomadas em relação às perturbações.

A primeira possibilidade - a Lacuna - remete à ignorância da situação perturbadora devido à ausência de repertório por parte do sujeito, não existindo, portanto, subsídios para a incorporação da instabilidade surgida em seus esquemas cognitivos.

Já nos casos do sujeito apresentar estruturas cognitivas capazes de abrigar as perturbações advindas do exterior, tal apropriação advém de conflitos, podendo gerar as condutas alfa, beta ou gama, que, nessa ordem, revelam um aumento do grau de modificações dado ao sistema de ideias do indivíduo, conforme já exposto anteriormente. 
Com base nos elementos teóricos expostos até aqui, procuramos direcionar a análise dos dados obtidos com os licenciandos em Física da Universidade de São Paulo para uma classificação inicial de acordo com as situações do cotidiano docente que pudessem ser caracterizadas como perturbações aos futuros professores, quando de suas intervenções no ambiente do estágio.

Portanto, categorizamos os episódios de interesse acadêmico de acordo com o tipo de perturbação (Lacuna ou Conflito, sendo este último capaz de gerar uma conduta alfa, beta ou gama) surgida, para, a partir deste ponto, analisarmos os caminhos criativos desenvolvidos pelos estagiários a partir da situação de instabilidade inicial, procurando compreender a dinâmica deste processo, mediante o movimento dos elementos inerentes ao trajeto criativo.

Desta forma, em um quadro mais geral, para cada situação de instabilidade procuramos delinear as possíveis situações de lacunas ou conflitos nos futuros professores, bem como as necessidades que os movem, os repertórios e experiências a que se remetem para a resolução das mesmas e, finalmente, a nova criação elaborada que, no caso particular deste trabalho, caracteriza-se por um novo Conhecimento Pedagógico de Conteúdo (PCK) elaborado (Grossman, 1987).

Ainda nessa linha de pensamento, salientamos que o ambiente onde os episódios de ensino foram gerados trata-se de um processo de estágio de cunho investigativo e supervisionado (ABIB, 2010). Dessa forma, em um primeiro momento, nossa hipótese para a aprendizagem da docência aproxima-se dos esquemas propostos por Shulman (op.cit.) em seu Raciocínio Pedagógico, uma vez que o futuro docente é inserido em um ambiente com significados e elementos culturais específicos, que propicia feedbacks de sua prática, após a possibilidade de reflexão das mesmas.

Um dos ambientes propícios à tal reflexão é representado pelas reuniões semanais de supervisão, onde os estagiários têm a possibilidade de socializar suas experiências na prática docente com o supervisor e outros licenciandos. Além dessa possibilidade, também ressaltamos a importância do caráter investigativo do estágio realizado, uma vez que os futuros docentes buscarão, no ambiente escolar, a solução para questões de pesquisa exploratória relacionadas ao Ensino de Física. 
Tal articulação entre a supervisão e a investigação da própria prática por parte do licenciando nos remete a um entorno cultural frutífero para o aparecimento de questionamentos sobre o cotidiano escolar, docente e das próprias metodologias empregadas pelos futuros docentes, o que, em referência à terminologia empregada por Shulman na elaboração de seu Raciocínio Pedagógico, corrobora com o surgimento de "novas compreensões" por parte dos estagiários no tocante às suas visões de ensino e aprendizagem.

A seguir, iniciaremos a análise de tais situações envolvendo nossos sujeitos de pesquisa - O Grupo I, constituído pelos estagiários R e C, e o Grupo II, representado pelos estagiários A, L e W. Salientamos, entretanto, que o estudo realizado não conseguiu constatar todas as perturbações acima citadas para os dois grupos de estágio analisados.

Enfocamos também que, devido às características metodológicas utilizadas neste trabalho e já expostas no capítulo anterior, o processo de estágio realizou-se em grupo de estagiários, dificultando uma individualização do processo criativo por parte deste pesquisador. Devido a este fato, optamos por tratar o desenvolvimento do processo de criação dos futuros professores, bem como a elaboração dos possíveis Conhecimentos Pedagógicos de Conteúdo de maneira mais global, considerando-se tais intervenções como construções coletivas do grupo de licenciandos.

A análise que segue explorará que, no caso específico do grupo I, as individualizações dos momentos de criação, bem como os Conhecimentos Pedagógicos de Conteúdo gerados foram possíveis, devido ao fato dos integrantes do grupo ministrarem as aulas do estágio separadamente, revelando especificidades do comportamento de cada um dos licenciandos.

Já em relação ao grupo II, seus integrantes ministraram em conjunto todas as aulas referentes ao estágio, dificultando o processo de individualização de cada estudante. Entretanto, como será exposto na sequência da análise, o grupo de estagiários efetuou em conjunto, não apenas as aulas, mas também todos os planejamentos e discussões acerca das mesmas, sendo possível constatar similaridades nas falas e características de interesse acadêmicos dos futuros professores pertencentes a esse grupo. Dessa forma, tal fato nos permitiu o tratamento desses licenciandos como uma 
única unidade de análise, com desenvolvimento coletivo que se aproximava do aspecto individual de cada um dos estudantes durante a realização do estágio analisado.

\section{O Grupo I}

\subsection{Sujeitos, Contexto e Trajeto do Estágio}

O grupo I apresentava-se composto por dois estagiários ( $\mathrm{R}$ e $\mathrm{C}$ ), ambos regularmente matriculados no $8^{\circ}$ semestre do curso de licenciatura em Física da Universidade de São Paulo (USP) e frequentes às aulas da disciplina de Metodologia do Ensino de Física II oferecida pela Faculdade de Educação desta Universidade.

O estagiário R, quando da execução da pesquisa, apresentava 26 anos de idade e sua experiência relacionada à docência resumia-se aos estágios obrigatórios relativos às disciplinas de natureza pedagógica de seu curso de graduação. Apesar de citar uma grande quantidade de horas cumpridas neste tipo de atividade, ele enfatiza que, apenas nas disciplinas de Metodologia do Ensino de Física I e II ocorreu sua real atuação enquanto professor regente de uma turma. Como caracterização deste sujeito, vale ressaltar que sua escolha pelo curso de licenciatura não foi tão direta, sendo que a escolha pelo mesmo foi realizada, segundo seus relatos na entrevista final, após diversas reprovações ocorridas em disciplinas do curso de Bacharelado em Física.

Apesar do curso de licenciatura em Física ter surgido como segunda opção para o licenciando, o mesmo, após contato com a prática profissional, passou a se dedicar às atividades do curso, considerando o estágio como um disparador de seu interesse pelas situações ligadas ao magistério.

Por outro lado, o estagiário $\mathrm{C}$ tinha 32 anos de idade, apresentando como experiência docente, além dos estágios realizados nas disciplinas de caráter pedagógico do curso de licenciatura em Física, a atuação como professor particular durante 5 anos, prioritariamente para alunos da rede privada de ensino do município de São Paulo, além de experiência em cursinhos preparatórios para exames vestibular.

$\mathrm{O}$ trajeto profissional de $\mathrm{C}$ até chegar ao curso de licenciatura em Física apresenta-se menos direto do que aquele realizado por $\mathrm{R}$, sendo que o mesmo chegou a cursar dois anos do curso de Engenharia em uma instituição privada de ensino superior. Por influência de um primo que era Físico e o levou para visitar os laboratórios da 
Universidade de São Paulo, seu interesse pela carreira aumentou, culminando com sua entrada no curso de Bacharelado em Física desta instituição.

Em convergência com a trajetória de $\mathrm{R}, \mathrm{C}$ transferiu-se para a licenciatura em Física buscando, segundo seu relato na entrevista final, uma pretensa tranquilidade no tocante à cobrança acadêmica, também após diversas reprovações nas disciplinas do curso de Bacharelado. Entretanto, assim como R, o estagiário C acabou por se interessar pela questão pedagógica após o contato com a prática profissional da carreira docente, acabando por encontrar no curso de licenciatura, não uma segunda opção, conforme seu plano inicial, mas a possibilidade de, realmente, utilizá-lo como parte de seu desenvolvimento profissional.

No tocante ao processo de estágio, $\mathrm{R}$ e $\mathrm{C}$ realizaram seu projeto em uma escola pública estadual situada na zona oeste do município de São Paulo. A escolha pelo estabelecimento deu-se em virtude de $\mathrm{R}$ já ter realizado processos de estágio naquele local, o que contribuiu para uma maior receptividade para com os futuros docentes.

Salientamos que o fato do apoio prestado, tanto pela professora colaboradora, como pela equipe gestora da escola foi um ato recorrente no processo de estágio desses licenciandos.

No contexto descrito anteriormente, o grupo I tinha a oportunidade de desenvolver, como requisito parcial para aprovação na disciplina de Metodologia do ensino de Física II, um projeto de estágio que reunisse as dimensões de ensino e pesquisa. Desta forma, nos patamares de um estágio de cunho investigativo (ABIB, 2010), a intervenção a ser criada pela equipe deveria contemplar o tratamento de um tema relativo à Física para os alunos do ensino médio, bem como responder, ainda que de forma exploratória, uma questão de pesquisa inerente ao Ensino de Física, utilizando o ambiente do estágio para tal.

Entretanto, em um primeiro momento, os estagiários $\mathrm{R}$ e $\mathrm{C}$, decidiram por utilizar-se de um projeto de ensino já pronto, utilizado por eles em uma disciplina realizada anteriormente durante o curso de licenciatura em Física ${ }^{20}$. Tal fato, em uma interpretação isolada, poderia nos remeter a um nível próximo do reprodutor de criação (VIGOTSKY, 2009), se caracterizando pela utilização direta de repertórios já criados

\footnotetext{
${ }^{20}$ Metodologia do Ensino de Física I, ministrada por professor diferente da disciplina cursada atualmente.
} 
anteriormente, transportando-os para a situação atual. Insistimos novamente, porém, que a utilização reprodutora não é, necessariamente, negativa ao ensino, haja vista que, uma atividade didática bem sucedida pode ser transportada em seus procedimentos gerais para outras situações, com o intuito de repetir seu sucesso anterior.

Por outro lado, o ambiente profissional do docente apresenta uma complexidade de fatores que interagem juntamente com a utilização de intervenções em níveis próximos dos reprodutores, o que faz com que a ideia original acabe por se transformar na tentativa de se adaptar às novas situações que afloram. Tal fato pode ser percebido na análise dos resultados do grupo I, que inicialmente, pretendia utilizar o citado projeto já construído:

(Sup3-4:28)

Pesq: E o que vocês estão pensando em fazer?

C: Então... a gente tem um conjunto de atividades... um mini-curso, que a gente acabou desenvolvendo em um curso anterior...é basicamente o que a gente tinha desenvolvido lá...

A atividade citada pelo estagiário $\mathrm{C}$ refere-se a um conjunto de quatro aulas, criada em uma disciplina anterior com o intuito de se fazer um mini-curso denominado Física da Propulsão. Tais intervenções seriam baseadas, basicamente em experimentos e cálculos simples que buscassem representar a conservação da quantidade de movimento, culminando com a construção de um foguete movido à água pressurizada, na aula final. Com o problema de pesquisa citado anteriormente, o grupo I, em seus portfólios, elaborou uma sequência didática, transcrita a seguir:

(Port)

Aula 1 - utilização de vídeos sobre foguetes, problematizando a propulsão através da concepção dos alunos sobre o tema.

Aula 2 - com a utilização de dois skates, colocaremos alunos de massas diferentes em cada um, buscando que os alunos (sic) cheguem à relação entre a massa do corpo e a velocidade adquirida.

Aula 3 - utilizando-se uma bexiga cheia de ar, a soltaremos e faremos a problematização - O que faz a bexiga se mover?

Aula 4 - construção e lançamento de foguete movido à água pressurizada. 
Através de uma rápida análise do planejamento anterior, podemos constatar que o mesmo, devido a suas intervenções rápidas em cada etapa, representa, de fato, um mini-curso e, portanto, foi elaborado pensando-se, inicialmente, neste contexto específico. Apesar do já citado e aparente caráter reprodutor desta intervenção, no contexto de sua utilização enquanto projeto de estágio, vale ressaltar que, quando de sua primeira criação, na disciplina anterior, podemos notar a importância das experiências vividas e do repertório do criador na elaboração das ideias:

(Ent)

Pesq: E de onde veio a ideia do projeto?

C: Olha...um dos motivos de eu fazer Física é a parte experimental. Eu tenho um primo que também é Físico e me levou para conhecer os laboratórios...isso foi muito motivador... e se me motivou, pode motivar outras pessoas também...

Pesq: Mas e ofoguete?

C: Essa ideia da propulsão... no semestre passado, uma aluna minha que fazia aula particular comigo (sic), pediu ajuda para desenvolver este foguete, e ela falou que o pessoal da escola ficou muito motivado com isso, um ia espionar o foguete do outro, ficavam pensando na aerodinâmica...parecia bem legal... aí eu fui pesquisar para ajudá-la.

Os episódios anteriores corroboram com os referenciais vigotskianos e piagetianos da necessidade de aumento de repertório e utilização de experiências vividas como elementos que potencializam o caráter criativo (PIAGET, 1972; VIGOTSKY, 2009). O estagiário C apoia a primeira criação de seu projeto em sua própria experiência positiva com as experimentações na área de Física, bem como em pesquisas já realizadas que aumentaram seu repertório em relação à construção de um foguete com propulsão à água.

Entretanto, salientamos que a professora colaboradora, apesar de apoiar a proposta sugerida pelos estagiários, solicitou, veementemente, aos mesmos que, devido à deficiência em cálculos apresentada pelos estudantes, todas as intervenções dos futuros professores não deveriam utilizar-se da matemática.

No contexto anteriormente descrito e através da aplicação deste projeto, os estagiários R e C inserem-se no ambiente de sala de aula, ficando sujeitos às diversas 
situações perturbadoras que interferirão na elaboração de possíveis caminhos criativos para a solução das mesmas. A seguir, expomos um quadro-síntese com as características gerais do grupo de estagiários I.

Estagiários: R e C.

Idades: 26 e 32 anos, respectivamente.

Experiência em relação à docência: Estágios obrigatórios. No caso de $\mathrm{C}$, o mesmo também apresenta experiência em cursinhos preparatórios.

Situação Acadêmica: freqüentam o $8^{\circ}$ semestre da Licenciatura em Física. Concluíram todas as disciplinas da grade curricular relativas ao Ensino de Física.

Escola onde realizará o estágio: Pública Estadual, situada no município de São Paulo.

Série onde se realizará o estágio: 2o ano do Ensino Médio.

Professor colaborador: Apoia os estagiários a todo momento, juntamente com a equipe gestora da instituição. Possui experiência com o ensino de Física. Solicitou aos estagiários que não utilizassem cálculos matemáticos em suas aulas.

Projeto de Estágio (viés ensino): Abordar a conservação da Quantidade de Movimento com atividades experimentais, culminando com a construção de um foguete de garrafa pet que apresenta propulsão devido à pressão da água.

Projeto de Estágio (viés pesquisa): Verificar a motivação trazida pela utilização de atividades experimentais em aulas de Física.

Origem do Projeto: os estagiários utilizaram um projeto que já haviam confeccionado na disciplina de Metodologia do Ensino de Física I, no semestre anterior. Porém, na ocasião, a sequência didática foi planejada para a realização de um minicurso.

\section{Sequência didática:}

Aula 1 - Apresentação de um vídeo sobre a propulsão de foguetes. Após a exposição do mesmo, os estagiários problematizariam a questão da propulsão e sua relação com o conceito de Quantidade de movimento.

Aula 2 - ; Realização de demonstração experimental utilizando dois skates. Nessa aula, dois alunos ficariam sentados em seus respectivos skates e se empurrariam 
simultaneamente. Com o experimento, os estagiários buscavam discutir com os alunos a relação entre a massa e a velocidade atrelada ao princípio da conservação da quantidade de movimento.

Aula 3 - Realização de experimento utilizando bexigas. Os estagiários soltariam bexigas cheias de ar, procurando demonstrar, novamente, o princípio da conservação da quantidade de movimento, a partir do fato de que o ar é expelido em direção contrária ao movimento da bexiga.

Aula 4 - Os alunos construiriam um foguete de garrafa pet, sendo que o mesmo apresentava sua propulsão devido à pressão de água colocada em seu interior.

Quadro 1 - Síntese da caracterização do Grupo de Estágio I

$\mathrm{Na}$ sequência, iniciaremos a categorização das situações vividas pelos estagiários em ambiente escolar, de acordo com o tipo da instabilidade inicial surgida e sua respectiva resposta, bem como o desenvolvimento criativo dado pelos licenciandos após a constatação da mesma.

\subsection{O Caminho Criativo Lacunar}

Para Piaget (1976), as lacunas, ou seja, a falta de repertório adequado para tratar uma situação de instabilidade vinda do meio externo, são também consideradas formas de perturbação. Nesses casos, a ausência de elementos que pudessem assimilar os fatos externos ao sistema cognitivo do estagiário acaba por fazer com que o licenciando se veja sem possibilidade de reação a tais fatos.

Desse modo, selecionamos episódios relativos à atuação dos estagiários R e C, integrantes do grupo I, onde constatamos tal comportamento. Apesar da existência da lacuna sugerir uma ausência de novas interações por parte do futuro professor, optamos por tratá-la como um possível caminho criativo, haja vista que o licenciando, em uma alusão ao extremo reprodutor do espectro criativo, recorrerá à última criação elaborada, não conseguindo efetuar adaptações coerentes na mesma face à inexistência de repertório para tal.

A seguir, ilustraremos tal fato com uma situação de Caminho Criativo Lacunar ocorrido na $2^{\mathrm{a}}$ aula, devido a uma perturbação motivada pela falta de planejamento dos integrantes do Grupo I em relação ao tempo didático. 


\subsubsection{A Organização do Tempo Didático}

De acordo com a sequência didática apresentada pelo Grupo I, a aula 2 deveria estar relacionada com a realização de um experimento envolvendo dois skates, nos quais seriam colocados dois alunos, que deveriam se empurrar mutuamente. Tal demonstração buscaria estabelecer um relacionamento entre as variáveis massa e velocidade dos móveis em questão, procurando verificar a relação inversamente proporcional existente entre elas.

Por problemas relacionados ao horário da escola, o estagiário $\mathrm{R}$ acabou por ministrar tal aula antes do estagiário $\mathrm{C}$, e os resultados não foram muito convergentes com suas expectativas, conforme ilustram os episódios a seguir, extraídos das reuniões de supervisão e do portfólio do licenciando.

$$
\text { (Sup5-1:02) }
$$

R: olha...vou falar que foi uma aula dificil de se dar porque...eu acho que o planejamento da aula não foi bom... a aula... a gente pensou assim... a gente ia usar dois skates... mas aí a gente só conseguiu um... a gente teve que improvisar... uma pessoa ia ficar em cima do skate, dá um pulinho pro lado e "espirra" o skate para o outro lado...

(Port)

R: A atividade foi rápida demais... eles [os alunos] acharam a atividade boba, com resultados óbvios demais... eles ficaram esperando o sinal tocar.

O episódio acima identifica uma das principais consequências da não adequação do contexto de trabalho do grupo à atividade utilizada. Retomando o contexto de criação do projeto de estágio desse grupo, já havíamos expressado que as intervenções elaboradas haviam sido criadas para um ambiente de mini-curso e ainda, com utilização de cálculos matemáticos para a comprovação da conservação da quantidade de movimento.

Para a aplicação da citada aula, os estagiários, visando às adaptações propostas pela professora colaboradora, suprimiram a utilização da matemática que estaria 
envolvida no evento, mas o simples fato de retirar tais procedimentos numéricos, criou um vazio após a realização do experimento, conforme relatado pelo estagiário R.

(Sup5-3:08)

R: A discussão não foi muito bem conduzida... o jeito que os conceitos estavam sendo trabalhados não estavam bons...a experiência aconteceu muito rápido...

Pesq: Mas você não teve essa noção antes de entrar na aula?

R: Não...foi durante a aula. Aí eu tentei trazer outros exemplos, que eu já tinha dito... foi um improviso..

(Ent)

R: A gente não tinha ideia do que ia fazer depois...os alunos.ficaram esperando dar o sinal...

Os trechos acima mostram que o licenciando $\mathrm{R}$, ao ser questionado durante a reunião de supervisão, efetua reflexões sobre sua ação (SCHÖN, 2002) ao analisar a fragilidade da condução da discussão em sala de aula. Tal situação retratou a necessidade que foi imposta ao futuro docente de criar, durante sua prática, uma solução rápida para a instabilidade surgida, mas desta vez, nos parece que os esquemas mentais do futuro professor se depararam, não com um conflito, mas com uma lacuna cognitiva, que impossibilitou a criação de uma solução coerente ("não era esse o objetivo da aula...foi um improviso!"), face à ausência de informações de repertório e experiência (PIAGET, op.cit. e VIGOTSKY, op.cit.) suficientes para lidar com a nova situação.

A cena acima também nos permite inferir acerca da conduta de $\mathrm{R}$ ao se deparar com a situação perturbadora. $\mathrm{Na}$ ausência de elementos que pudessem favorecer a assimilação da instabilidade em seus sistemas cognitivos, Durante a supervisão, o estagiário, mesmo que de forma inconsciente, recorre à última criação elaborada ("Aí eu tentei trazer outros exemplos, que eu já tinha dito!"), reportando-nos ao extremo reprodutor do espectro criativo. Salientamos, portanto, a importância da reunião de supervisão como um momento propício às trocas de informações entre o grupo de estágio e o supervisor, bem como entre os próprios licenciandos.

Nessa linha, a experiência vivida por $\mathrm{R}$, ao ser relatada durante a reunião de supervisão da disciplina de Metodologia do Ensino de Física II, acabou por se 
transformar em orientação de prática para o licenciando C, proporcionando alterações em seus esquemas criativos, conforme segue abaixo.

(Sup4-6:16)

Pesq: E vocês vão dar esta aula [experiência dos skates] de novo?

C: Quem vai dar essa aula sou eu. Mas, depois de tudo isso, a gente já está pensando em fazer algumas modificações...

A positividade desta troca de informações pode ser verificada na fala de C, após ministrar esta aula.

(Sup6-2:14)

C: Fiz, na semana passada, aquela aula do skate... mas eu tive que improvisar, também...só consegui um skate, mas aí, por causa do tempo curto [citado por $R$ em sua experiência com esta aula] eu fui variando...uma vez eu colocava pessoa de mais massa, depois com menos massa... e foi tudo bem... a maioria das pessoas participou, tiravam dúvidas, responderam o questionário...

Neste ponto, é possível perceber que a socialização da experiência de R permitiu um aumento de repertório a $\mathrm{C}$, contribuindo para uma diminuição da possibilidade de surgimento de lacunas, como ocorrido anteriormente. Tal fato nos remete a uma provável Zona de Desenvolvimento Proximal (ZDP) estabelecida por Vigotsky (2001), permitindo ao licenciando menos experiente contar com as informações e auxílio de outro integrante do grupo. Salientamos, novamente, que tal ZDP ocorreu durante uma reunião de supervisão, demonstrando, portanto, um ambiente propício para tal prática.

Os episódios aqui citados, representando o Caminho Criativo Lacunar do Grupo I, apesar de não proporcionar novas adaptações aos esquemas mentais docentes, permitiram ao grupo de licenciandos evidenciar a falta de cuidado dos mesmos com os planejamentos das atividades propostas, haja vista que, um dos fatores responsáveis pelos imprevistos surgidos durante a prática de $\mathrm{R}$ foi, exatamente a falta de um skate, fato este que se repetiu com $\mathrm{C}$, mesmo após sua tomada de conhecimento dos problemas citados por R na reunião de supervisão anterior, conforme ilustrado a seguir. 
(Ent)

C: Então... o planejamento antecipado é fundamental...ter todos os materiais prontos com antecedência.

O Caminho Criativo Lacunar, devido ao fato do docente não apresentar condições de assimilação da perturbação surgida, não se desenvolve em novas adaptações nos esquemas mentais docentes, não culminando, portanto, com a criação de novas vertentes (conteúdo, pedagógica e contexto) de um novo Conhecimento Pedagógico de Conteúdo.

Entretanto, vale salientar que tais situações perturbadoras podem instigar o futuro docente a adquirir repertórios adequados para o enfrentamento de situações futuras similares, como ocorrido com o próprio estagiário $\mathrm{R}$ e descrito no item 4.4.3 deste capítulo, contribuindo, portanto, na elaboração de outros possíveis Caminhos Criativos futuros.

A seguir, procuramos expor um esquema ilustrativo do fato ocorrido no Caminho Criativo Lacunar analisado.

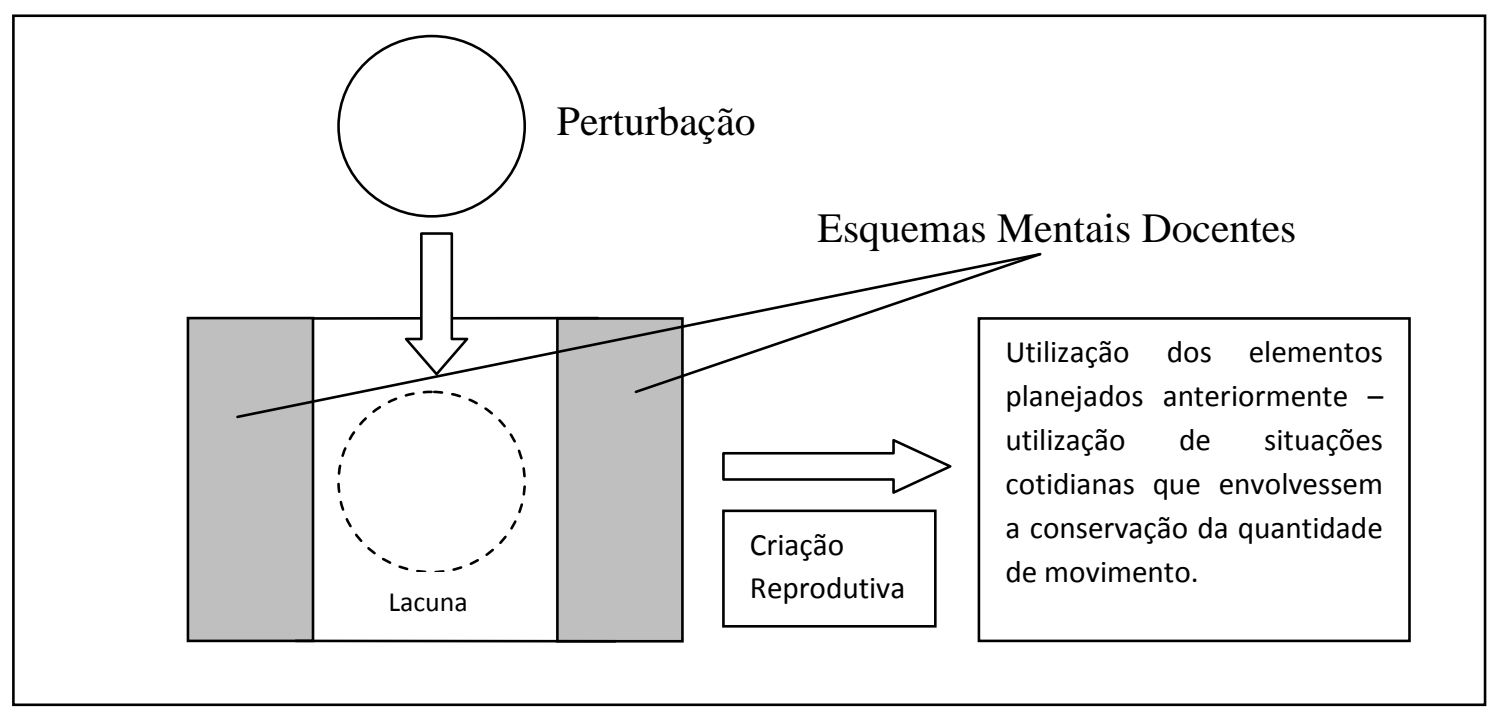

Fig.10 - Esquema do Caminho Criativo Lacunar do Grupo I

De acordo com a representação anterior, podemos verificar que a perturbação, originada a partir dos elementos do contexto social e cultural da intervenção, consegue ser assimilada pelo sistema de conhecimentos docentes. Entretanto, tal sistema não apresenta elementos suficientes em seu repertório para resolver a instabilidade surgida, configurando-se, portanto, uma região de lacuna. 
Conforme já exposto, tal ausência de repertório, aliado a uma questão de sobrevivência docente (HUBERMAN, 1992), nos parece levar o estagiário a repetir o que já estava no plano didático, na tentativa de um preenchimento do tempo restante de aula, sem sucesso, porém. Tal ato, consequentemente, acaba por trazer a utilização do mesmo Conhecimento Pedagógico de Conteúdo - utilização de exemplos do dia-a-dia para expor situações corriqueiras que buscassem representar a conservação da quantidade de movimento - que já havia sido planejado anteriormente, permitindo-nos inferir acerca de uma criação próxima ao extremo reprodutor do espectro criativo.

Em outra linha de pensamento, a perturbação surgida pode ser assimilada diretamente nos esquemas mentais docentes já existentes, podendo se caracterizar uma conduta do tipo beta, conforme exposto a seguir.

\subsection{O Caminho Criativo Beta}

O Caminho Criativo Beta é uma categoria de criação caracterizada pela inserção da perturbação inicial em um sistema cognitivo docente já existente e estabilizado, tal qual a conduta beta descrita na teoria piagetiana (PIAGET, 1976).

A situação de instabilidade exterior procura ser explicada pelo sujeito com os esquemas mentais já pertencentes ao seu repertório, criando, portanto, uma adaptação em relação aos esquemas anteriores, porém sem a elaboração de um novo sistema conceitual para explicar a perturbação original.

Em nossa análise das falas e registros dos licenciandos do Grupo I, conseguimos identificar uma situação representativa do Caminho Criativo Beta, produzida, originalmente pelo professor colaborador da escola onde ocorria o estágio dos futuros professores, demonstrada na sequência.

\subsubsection{Limitações Impostas pelo Professor Colaborador}

Conforme explicitado na caracterização do contexto do estágio do Grupo I, os estagiários pretendiam aplicar uma sequência de aulas previamente elaboradas para um 
mini-curso desenvolvido para uma disciplina de graduação cursada anteriormente pelos integrantes da equipe.

A proposta efetuada consistia de demonstrações experimentais e matemáticas acerca da conservação da quantidade de movimento, de tal forma que, no término do projeto, o estudante construiria um foguete com garrafas plásticas, apresentando propulsão com base na pressão de água e ar contidos no interior do mesmo.

Face ao fato do projeto de estágio já estar previamente determinado, possíveis alterações no mesmo traziam preocupações aos futuros professores no início do processo de estágio. Tais alterações pareciam acabar com uma pretensa comodidade por parte dos licenciandos, que deixaram claro não estar supondo a existência da possibilidade de mudanças no andamento de um curso previamente estruturado, conforme demonstrado a seguir.

(Sup1 - 12:55)

$R$ : O medo nosso é que a professora lá [na escola] não goste da nossa ideia e a gente seja obrigado a mudar os planos.

(Sup2 - 8:37)

$R$ : A gente vai falar com a professora amanhã, porque eu nem sei se ela vai aceitar...onde ela está na matéria, se já passou da conservação do momento...

Apesar da preocupação, a professora colaboradora demonstrou-se extremamente solícita com os licenciandos, haja vista que, mesmo já tendo ministrado o conteúdo relativo à quantidade de movimento em suas turmas, aceitou a proposta do grupo, com uma ressalva, exposta abaixo.

(Port)

$R$ : A professora pediu para a gente não utilizar a matemática durante as aulas, pois os alunos poderiam perder o interesse.

(Sup $7-19: 10)$

C: E a professora pediu para a gente não dar a abordagem matemática...quando a gente trazia a questão (sic), deveria ser sem conta. Nesta escola, ela [a professora] acabou relatando para a gente 
que, no $2^{\circ}$ colegial (sic), o nível de matemática do pessoal [alunos] é de $7^{a}$ série... no que é passado, tento usar o menor número possível de contas.

(obs: neste momento, todos os integrantes dos demais grupos presentes na reunião de supervisão acenam a cabeça, concordando com a declaração de $C$ ).

O fato descrito acima gerou um estado de suspensão no projeto, até então, elaborado. A sequência didática que estava prevista pelos estagiários (criada para um contexto diferente deste) procurava efetuar abordagens numéricas com frequência, gerando um clima de insatisfação, conforme se pode verificar na fala a seguir.

(Sup3-5:21)

$R:$ A gente ia desenvolver atividades experimentais com eles...ir para quadra, levar skates, discutir a velocidade... era uma análise qualitativa e quantitativa... agora vamos ter que rever.

O pedido da professora colaboradora solicitando a não utilização de qualquer artefato matemático durante a aplicação do projeto de estágio, a nosso ver, pode ser enquadrado como uma situação deflagradora de perturbação conflituosa (PIAGET, 1976), pois, a partir deste ponto, os estagiários se viram obrigados a reformular as atividades propostas.

Entretanto, ao analisarmos o novo planejamento realizado pelos estagiários, verificamos que, em sua essência, ele permanecia com o mesmo formato, salvo pela ausência das formalizações matemáticas solicitadas pela professora colaboradora. Tal fato permite-nos inferir acerca de uma comodidade do grupo, que não se utilizou de tempo ou reflexão mais profunda para a montagem das novas aulas.

Desta forma, os fatos ocorridos nesta sequência de episódios apontam para a inserção da instabilidade geradora no esquema de conhecimentos já existente dos futuros docentes, possibilitando a classificação de tal situação em uma conduta beta (PIAGET, 1976), onde o sujeito busca uma compensação da instabilidade externa, incorporando-a na estrutura já organizada, "ocorrendo, para o indivíduo, um aumento de compreensão e coerência (MACEDO, 2009, p.308)" em relação aos fatos surgidos.

Do ponto de vista da criação, interações didáticas categorizadas como condutas beta situam-se, no espectro criativo, em regiões mais próximas do caráter reprodutor 
(VIGOTSKY, 2009), haja vista que, apesar da ausência de novos sistemas conceituais elaborados para o enfrentamento das instabilidades surgidas, o futuro professor acaba por inseri-las em esquemas de conhecimentos já existentes, podendo causar, inclusive, um aumento de elementos referentes a seus repertórios para futuras criações.

Até o presente momento, notamos, tanto no Caminho Criativo Lacunar, como no Caminho Criativo Beta, que as perturbações surgidas no ambiente profissional dos estagiários inseriram, respectivamente, nenhum ou pouco acréscimo de novos esquemas aos sistemas mentais dos futuros professores, não se podendo caracterizar elementos que promoveriam um novo Conhecimento Pedagógico de Conteúdo (SHULMAN, 1987, GROSSMAN, 1990) para o estagiário sujeito a tal situação.

Desse modo, a análise do novo projeto criado pelo grupo I em sua conduta beta acaba por trazer, além da alteração de conteúdo (retirada dos cálculos que seriam realizados para comprovar, matematicamente, a conservação da quantidade de movimento), a mesma forma de intervenção pedagógica, sem preocupação com o novo contexto onde seria aplicado o projeto.

Portanto, o PCK utilizado pelo grupo I, após a intervenção da professora colaboradora, não demonstrou, em sua essência, alterações significativas, caracterizando-se, apenas, pelo corte das operações matemáticas, conforme buscamos expor no esquema a seguir.

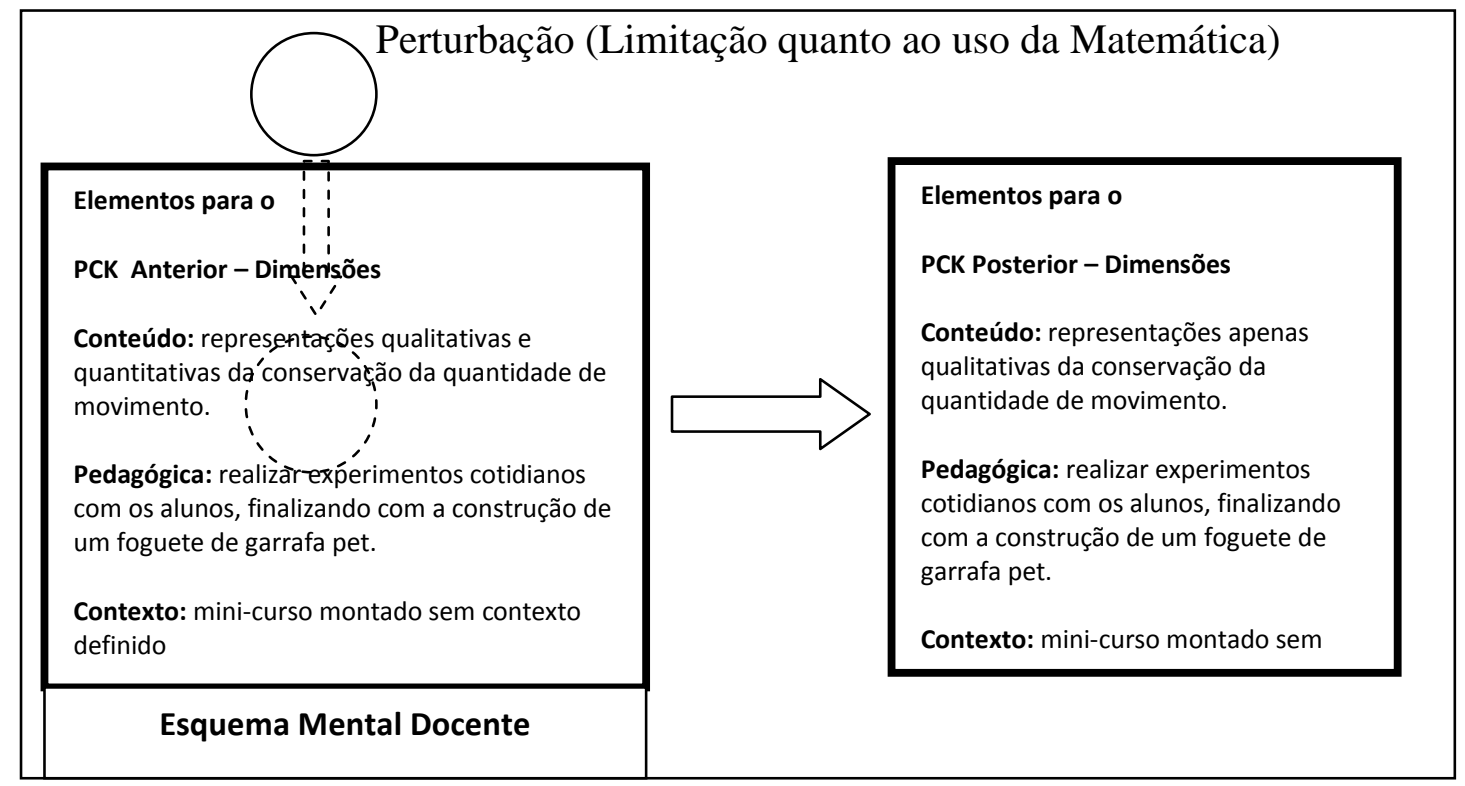

Fig. 11 - Esquema do Caminho Criativo Beta do Grupo I 
O esquema anterior procura demonstrar que, em um conduta beta, a psicologia piagetiana considera que os elementos inerentes à perturbação conseguem ser assimilados ao esquema cognitivo até então elaborado. Tal processo faz com que os fatores de instabilidade, oriundos do meio sociocultural do licenciando, consigam ser explicados e incorporados pela estrutura vigente, não causando alterações significativas em sua essência.

Salientamos, nessa etapa que, tal confecção do projeto de estágio não sofreu alterações nem discussão nas reuniões de supervisão, haja vista que as mesmas se iniciaram após a elaboração do mesmo. Apesar desse fato e ainda baseados na psicologia piagetiana, verificaremos, a seguir, situações perturbadoras conflituosas que implicaram em alterações mais intensas no projeto confeccionado e esquemas mentais dos estagiários do grupo I - as condutas do tipo gama.

\subsection{O Caminho Criativo Gama}

Segundo Macedo (2009, p.308), as condutas do tipo gama são caracterizadas pela incorporação dos elementos do conflito surgido no próprio sistema, causando uma "variação intrínseca" deste sistema.

Para Piaget (1976), o comportamento do tipo gama atua de forma mais intensa nos esquemas mentais do indivíduo, sendo provocado por conflitos entre estes esquemas atuais no momento que em que eles não são capazes de explicar de forma coerente as instabilidades surgidas. Desse modo, a conduta gama implica, mediante a existência de conflitos, em uma reestruturação dos sistemas explicativos do futuro professor para adaptar a nova perturbação a esquemas coerentes com a mesma.

Tais situações de instabilidade poderão ser ilustradas a seguir com a apresentação de episódios onde os estagiários se deparam com momentos perturbativos, ocasionando conflitos e necessidades de resolução da situação imposta. Os momentos descritos na sequência procuraram abranger os integrantes do Grupo I em situações de prática de sala de aula e de planejamento de intervenções futuras, quando os licenciandos, respectivamente, se depararam com preocupações relativas à utilização de materiais didáticos e à aprendizagem do estudante. 


\subsubsection{A Utilização de Recursos Didáticos}

As cenas representadas neste tópico referem-se à primeira intervenção planejada pelo Grupo I no ambiente escolar. A aula planejada procurava efetuar uma apresentação inicial sobre o Princípio da Conservação da Quantidade de Movimento. Para tanto, os estagiários propuseram a exposição de um vídeo que tratava de tal fenômeno mediante a explicação do lançamento de foguetes. Após o término do vídeo, os licenciandos planejaram uma discussão com a sala sobre o conteúdo tratado.

Nesta primeira aula do projeto, o estagiário $\mathrm{C}$, por motivos relacionados a uma troca de horários na escola, acabou por ministrá-la sozinho. Conforme exposto anteriormente, tal aula seria baseada na utilização de um vídeo sobre o lançamento de foguetes, apresentando como objetivo a problematização da forma de propulsão dos mesmos.

$\mathrm{Na}$ avaliação de $\mathrm{C}$, esta aula ocorreu de forma tranquila:

(Sup4 - 18:52)

C: Começou com um vídeo introdutório, com relação a propulsores, lançamento de foguetes americanos, chineses... eles até perguntaram: tem foguete no Brasil?...mostramos o vídeo e o pessoal ficou quieto... a professora não acreditava...eles [os alunos] participaram bastante...tinha até um "aluno-problema" que perguntou o que a gente ia fazer...aí ele pegou a carteira dele e sentou na frente do computador para ver o que ia acontecer.

Apesar do sucesso de $\mathrm{C}$ em sua primeira imersão no ambiente deste estágio, o licenciando R, ao lecionar a mesma aula para outra turma, sofreu com os imprevistos específicos do círculo social e cultural onde se encontrava, imprevistos estes que permeiam a função docente:

(Sup4-24:49)

R: Eu dei a mesma aula hoje...mas eu tive um problema...eu não consegui passar o vídeo porque o aparelho de DVD não estava funcionando...

Pesq: E aí? 
R: Aí...eu dei um jeito. A aula não pode parar! Comentei, desenhei o foguete na lousa e expliquei no quadro...Não tive problema de disciplina.

O episódio acima retrata, claramente que, no surgimento de imprevisto durante a prática, o futuro docente, ainda que iniciante, tem como principal intuito manter a aula, como se nada o estivesse desestabilizando (“A aula não pode parar!”), fato este, que poderia, na visão do estagiário, provocar indisciplina da sala e dificuldades na retomada do conteúdo quando a solução do imprevisto surgisse.

Tal ponto de vista nos é reforçado por Bejarano (2003) e Fuller (1969), que ao analisarem as fases de evolução docente, alertam para o fato do futuro professor, em início de suas atividades (ainda que pré-profissionais), preocupa-se muito com o controle da sala, ocasionando "uma fase pré-ensino, com uma escassa ou inexistente preocupação com a aprendizagem (FULLER, op.cit.)".

Desta forma, o estagiário buscou uma solução rápida, com o intuito de não transparecer aquele momento de instabilidade, retratando o vídeo na lousa, como um desenho animado. Tal solução, caso o estagiário estivesse em um contexto sociocultural mais tranqüilo, poderia não ter sido a escolhida, entretanto, no ambiente da sala de aula, uma das principais preocupações de um professor iniciante, também segundo Huberman (1992, p.39), é sobreviver àqueles momentos, sendo necessária uma resposta rápida para afastar a maior preocupação do docente nesta fase - a indisciplina da sala, que mantém o risco da perda de controle da mesma e uma difícil retomada do conteúdo trabalhado.

A solução de $\mathrm{R}$ ao imprevisto surgido também pode ser analisada do ponto de vista piagetiano (PIAGET, 1972), onde a necessidade de repertórios anteriores é fundamental para a criação do novo. No caso deste estagiário, se o mesmo não tivesse assistido ao vídeo preliminarmente, talvez a solução criada não fosse tão instantaneamente remetida ao seu repertório e a reação da turma àquela aparente instabilidade poderia ter sido outra.

Desse modo, podemos inferir a respeito do surgimento de uma situação de perturbação conflitiva, a qual desencadeou uma necessidade criativa no futuro professor, fazendo o mesmo se remeter a seus repertórios anteriores. Salientamos novamente que a solução encontrada pelo licenciando buscou exemplos que pudessem oferecer uma rápida resposta, face à preocupação principal deste com o controle da sala. 
Salientamos aqui que o conflito sofrido por R, bem como sua superação, relaciona-se diretamente com as questões sociais e culturais do ambiente específico onde o licenciando se encontrava inserido, ou seja, a caracterização social daquela sala de aula, que já havia sido descrita como indisciplinada pela professora colaboradora, colaborou para a instalação de um conflito de natureza sociocognitiva (CASTORINA, 2008) e a forma de sua superação, visando às funções psicológicas superiores (VIGOTSKY, 2001).

Para corroborar a análise efetuada até este ponto, ao questionarmos o estagiário $\mathrm{R}$ sobre a origem de sua reação à perturbação, verificamos que o mesmo remeteu-se a professores da escola básica, conforme ilustrado a seguir.

(Sup4-24:00)

R: (...) Acho que [a ideia] veio de um professor meu...acho que era de História. Quando a classe começava a ameaçar [fazer bagunça], ele ia para lousa e começava a escrever um monte de coisa para a gente ficar quieto.

A utilização destes tipos de exemplos por parte dos professores iniciantes nos é fundamentado por Beach \& Pearson (1998) ao afirmarem que professores novatos, ao se depararem com a resolução de conflitos no cotidiano escolar, buscam soluções paliativas e de curto prazo.

Nesse ponto, ressaltamos novamente, a importância do entorno cultural (VIGOTSKY, 2001) onde se situava o licenciando, quando da ocorrência da perturbação. A resposta rápida exigida do estagiário só ocorreu devido ao fato deste estar sob a pressão de uma aula inaugural em uma turma onde já havia obtido informes sobre ocorrência de atos de indisciplina. Dessa forma, o conflito de natureza sociocognitiva (CASTORINA, 2008) instalado se deve à instabilidade representada por um somatório de aspectos cognitivos e culturais daquele momento.

A título de avaliação, os estagiários, após esta primeira intervenção, julgaram positivas as situações de sala de aula, conforme expomos abaixo.

(Sup4-27:00)

C: A professora mostrou um diário com os trabalhos que os alunos entregavam...sempre os mesmos entregavam. Aí a gente pegou nosso questionário e viu que a maioria fez questão de responder...teve até 
alguns alunos que não tiveram tempo de acabar em sala e vieram correndo atrás de nós para entregar depois.

O trecho anterior traz o principal fator que validou as convicções dos licenciandos acerca do sucesso nesta primeira aproximação com os alunos - o questionário passado aos estudantes para que os mesmos respondessem sobre o conteúdo abordado com o vídeo, obtendo um retorno que nem mesmo a professora colaboradora da sala de aula havia conseguido.

Tal validação positiva nos pareceu permitir aos estagiários inserir a situação vivida no estágio em seus esquemas conceituais docentes, permitindo, portanto, a criação de um novo Conhecimento Pedagógico de Conteúdo (SHULMAN, 1987).

Tal conhecimento pode ser caracterizado através de suas dimensões (GROSSMAN, 1990), sendo possível, portanto, identificar elementos pertencentes aos patamares de contexto, conteúdo e pedagógico do mesmo.

Tomando-se, os relatos do estagiário $\mathrm{R}$, podemos constatar, na intervenção em sala de aula analisada, a exposição de elementos acerca do contexto de sala de aula:

(Sup4-24:58)

Contexto do relato: $R$ informa que, durante a apresentação de um vídeo, em sua primeira aula, após o imprevisto do aparelho de DVD não funcionar, o estagiário viu-se obrigado a desenhar as imagens da apresentação na lousa.

R: Aí... eu dei um jeito! [a aula] Não pode parar!...Não tive problema de disciplina...tinha um barulhinho ou outro, mas não aquela barulheira. Mas eu já tive essa experiência em estágio... a primeira aula, normalmente é mais tranquila, as outras, eles [os alunos] pioram... acho que vão se acostumando.

O episódio anterior retrata o momento de criação do estagiário R, onde ele, após constatar a impossibilidade da exposição do vídeo planejado, procura, de maneira rápida, uma solução que não permita que a sala se indiscipline, sua principal preocupação, conforme pode ser observado na fala acima. Tal necessidade de sobrevivência (HUBERMAN, 1992) faz com que o licenciando, mediante o conflito sociocognitivo iminente (PIAGET, 2002 e CASTORINA, 2008) crie uma intervenção, onde este reproduz as imagens do vídeo na lousa, intervenção esta baseada em seu 
repertório anterior (VIGOTSKY, 2009 e PIAGET, 1972), devido ao fato de já ter assistido ao vídeo anteriormente e adota um posicionamento já realizado por seu professor na escola básica, facilitando tal reprodução.

No tocante às concepções de $\mathrm{R}$, notamos, em corroboração com sua fala, a criação de elementos para um novo PCK, em caráter experiencial, na sua prática de estágio (“Mas eu já tive essa experiência em estágio!"). Tal elaboração remete-se às práticas já vivenciadas por $\mathrm{R}$ em situações anteriores, criando-se uma generalização de que as primeiras aulas são mais tranquilas para um docente no tocante à disciplina da sala ("a primeira aula, normalmente é mais tranquila, as outras, eles [os alunos] pioram... acho que vão se acostumando").

Salientamos ainda que, neste episódio, a concepção elaborada por R concentrouse na dimensão do contexto do ambiente de sala de aula (a reação dos alunos a uma possível instabilidade do professor, podendo gerar indisciplina), fator este que colaborou para a criação da estratégia metodológica (dimensão pedagógica) de R, onde a reprodução de imagens na lousa, apesar de poder causar uma instabilidade nos alunos, haja vista que os mesmos encontravam-se preparados para assistir a um vídeo, poderia se tornar uma possibilidade, pois, para o licenciando, a turma, dificilmente, apresentaria problemas de natureza disciplinar, por se tratar da primeira aula.

As dimensões de contexto e pedagógicas acima descritas se relacionam à necessidade de alteração do conteúdo a ser trabalhado, afinal, não seria possível a reprodução de todas as imagens do vídeo na lousa, assim como o licenciando não conseguiria, no tempo proposto para a aula, reproduzir todas as falas e animações inerentes a um vídeo. Tal criação na dimensão do conteúdo demonstra a elaboração do estagiário nesta vertente, em dependência com as dimensões pedagógicas e contextuais, sendo esta última, em nossa análise, a disparadora da criação das demais após a ocorrência do conflito.

Desse modo, os episódios analisados nessa intervenção demonstram elementos inferentes a uma elaboração de um novo Conhecimento Pedagógico de Conteúdo (GROSSMAN, 1990) por parte do estagiário R - expor a matéria na lousa parece diminuir a indisciplina na sala de aula - que recorreu a exemplos prontos e de eficácia comprovada, tal qual os modelos propostos pela literatura da área (BEJARANO, 2003, FULLER, 1969 e BEACH \& PEARSON, 1998) para suprir suas necessidades criativas daquele momento específico. A seguir, o esquema procura ilustrar tal situação. 


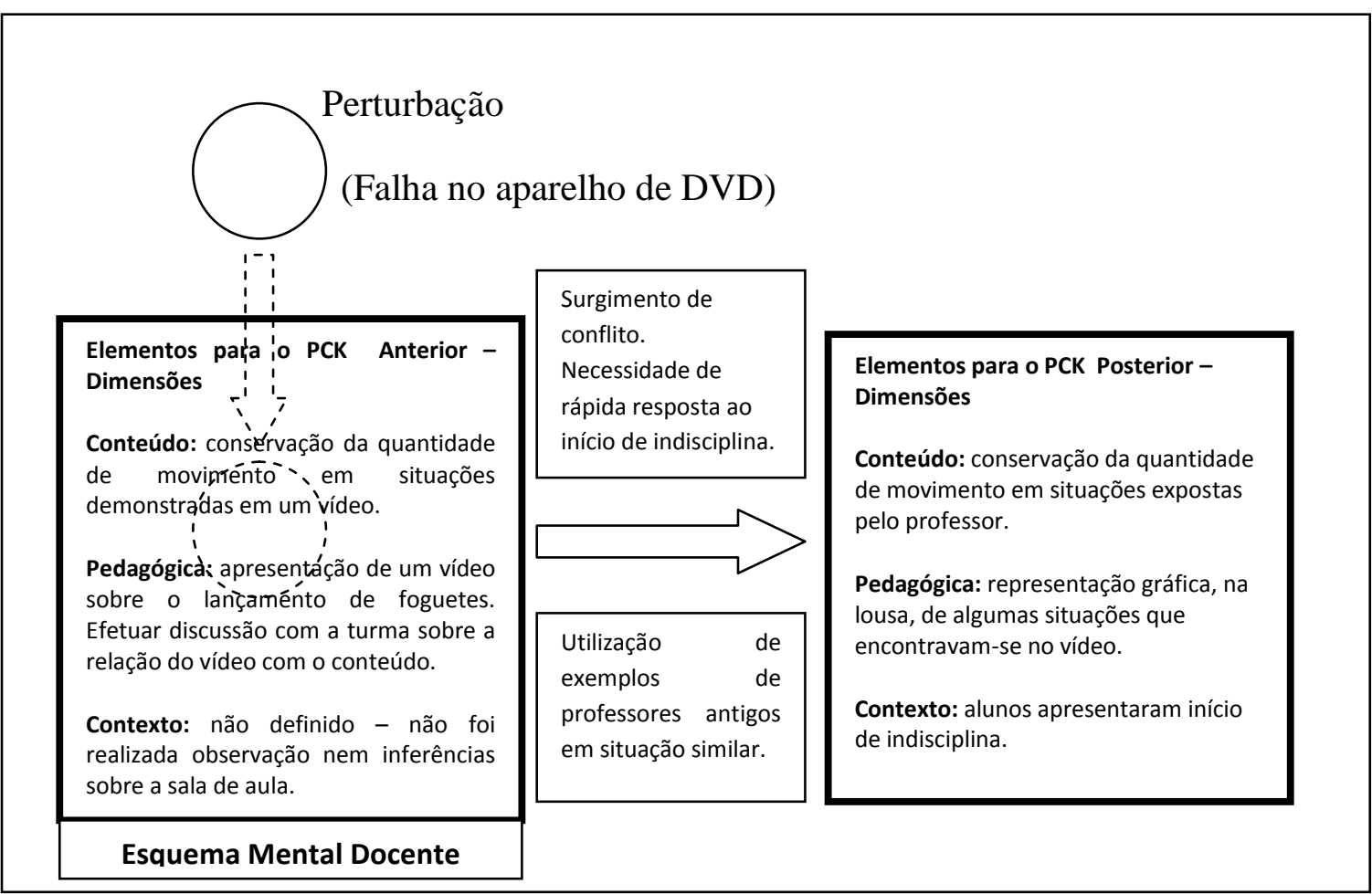

Fig.12 -Esquema de Caminho Criativo Gama do Grupo I

No esquema anterior, visualizamos que a perturbação é assimilada pelo sistema de conhecimentos do futuro professor, gerando conflito com o esquema cognitivo atual, que se demonstrou ineficaz na resolução da perturbação surgida. Nesse momento, face ao entorno sociocultural onde se encontra inserido o estagiário (uma sala de aula com início de comportamentos de indisciplina), afeta a resposta à instabilidade, sendo necessária uma rápida intervenção do futuro docente, que recorre a exemplos de comportamentos bem-sucedidos de seus ex-professores em situações similares, criandose um novo PCK.

O licenciando, quando dos relatos acerca da criação efetuada, não cita, explicitamente, uma recorrência aos seus repertórios específicos sobre as dimensões de contexto, pedagógica ou de conteúdo, mas estabelece relações com sua própria experiência e exemplos de seus professores, o que nos aponta para a elaboração de um Conhecimento Pedagógico de Conteúdo em um caráter Transformativo, conforme apontado por Gess-Newsome (1999).

Na sequência, abordaremos mais uma série de episódios do Grupo I, onde os integrantes de depararam com perturbações relativas à indisciplina dos estudantes. 


\subsubsection{A Indisciplina devido à utilização da Matemática}

Na continuidade das intervenções elaboradas, o grupo I iniciará sua penúltima aula, aplicando um experimento com bexigas. Para tanto, de acordo com o portfólio de ambos os integrantes da equipe, o experimento, inicialmente, consistiria na soltura de um balão cheio de ar, problematizando, posteriormente, o motivo pelo qual aquele movimento ocorreria.

Entretanto, devido à sugestão de um estagiário que integrava outro grupo de estágio, durante uma das reuniões de supervisão, o experimento foi recriado, amarrando-se a bexiga em um fio que seria preso na sala e, aí sim, soltando-a, podendo, desta forma, vislumbrar um movimento retilíneo, com maior facilidade de visualização.

Tal fato, ocorrido, portanto, durante a reunião de supervisão, demonstra-nos, mais uma vez, o ambiente de tais encontros, propício às trocas de informações entre estagiários que já haviam aplicado demonstração semelhante e aqueles que fariam isso pela primeira vez. A situação exposta nos permite, novamente, caracterizar uma Zona de Desenvolvimento Proximal - ZDP (VIGOTSKY, 2001) ocorrida entre licenciandos mais e menos experientes no tocante à aula em tela. Em suma, a socialização de sugestões e ideias relativas às intervenções em sala de aula ocorridas apontam para um aumento do repertório dos futuros professores.

Acerca desta aula, o estagiário R esclarece que:

(Sup6-4:24)

R: Eu fiz a experiência com as bexigas...foi legal, mas como eu tinha feito aquela experiência do skate e foi muito rápida, eu fiquei com medo de acontecer de novo. Como meu objetivo era falar da conservação da quantidade de movimento, primeiro eu falava sobre a lei, dizia o que era a quantidade de movimento, dava uns exemplos de caminhão batendo em carro(...) e no final, eu falava da bexiga e dava a experiência.

O episódio anterior busca demonstrar a importância que a instabilidade surgida na semana anterior (experimento dos skates), com lacuna cognitiva que impossibilitou o andamento da aula, ter sido fundamental para seu desenvolvimento durante o processo de estágio (“eu fiquei com medo de acontecer de novo!"). Claramente, a aula em 
questão foi fruto de um planejamento mais cuidadoso, apresentando uma sequência de atividades distribuídas coerentemente em relação ao tempo e sua dificuldade.

Apesar deste aparente aumento do cuidado com o andamento da intervenção, o estagiário R, ao contrário do solicitado pela professora colaboradora, insere algumas operações matemáticas para comprovar, numericamente, a conservação da quantidade de movimento, conforme exposto abaixo.

(Sup6-9:40)

$R$ : Eu resolvi fazer umas continhas simples... de quanto era a quantidade inicial e a final...Só que tem conta! Quando tem conta já tem gente que começa a dormir, tem gente que prefere ficar ouvindo música no celular...

Pesq: E na hora...você tentou fazer alguma coisa?

R: Aí eu perguntava alguma coisa que eu estava explicando para essas pessoas que estavam meio distraídas... “ - E aí, meu? O que acontece com a quantidade de movimento do caminhão se ele bater? ... eu já vi algum professor meu fazer isso...não lembro quem... dava certo...

$\mathrm{O}$ estagiário $\mathrm{R}$, ao tentar efetuar passagens matemáticas que comprovassem a conservação da quantidade de movimento, notou uma queda no interesse dos alunos, notando, inclusive, que muitos dormiam ou ouviam música enquanto ele ministrava a aula.

O licenciando, com um sistema cognitivo anterior que tratava a inserção da matemática como algo natural no estudo da conservação da quantidade de movimento, depara-se com um contexto sociocultural que apresenta expectativas diferentes em relação a tal utilização de cálculos. Tal episódio pode ser considerado como um provocador de desequilíbrio dos esquemas mentais docentes do licenciando e, portanto, produzido por uma perturbação seguida de uma conduta gama, haja vista ter sido capaz de gerar conflitos profundos e alteração dos esquemas do licenciando (PIAGET, 2002) no ambiente da sala de aula, fazendo com que o mesmo sinta uma legítima necessidade (RIGON, 2009 e VIGOTSKY, 2009) criativa de retomar a atenção e interesse da turma.

Em uma interpretação mais aprofundada, notamos novamente a importância conferida aos elementos culturais que o ambiente da sala de aula trouxe para confrontar 
as hipóteses de ensino iniciais do licenciando. Dessa forma, a instabilidade instaurada é fruto de uma perturbação influenciada por tais elementos, configurando-se o conflito surgido como sociocognitivo (CASTORINA, 2008).

Por sua vez, o estagiário, na tentativa de não perder, ainda mais o controle disciplinar da sala, busca, em sua criação, remete-se a modelos que, em seu repertório, já possuam eficiência comprovada em situações similares, o que geraria uma solução rápida (BEACH \& PEARSON, 1998) para a instabilidade surgida. A resposta encontrada por $\mathrm{R}$ foi retomar exemplos de gestão de classe de seus professores enquanto este era estudante de educação básica ("eu já vi algum professor meu fazer isso... dava certo").

Em um aspecto mais geral, a intervenção atual busca ilustrar o fato da matematização como influenciador na elaboração de Conhecimentos Pedagógicos de Conteúdo por parte dos estagiários. A seguir, pode-se ver como tal tipo de conduta traz repercussões para o desenvolvimento profissional do futuro professor.

(Sup6-4:24)

$R:$ (...) como eu tinha feito aquela experiência do skate... e foi muito rápida... eu fiquei com medo de acontecer a mesma coisa... [na aula atual] eu falava da lei da conservação...dizia o que era a quantidade de movimento, dava exemplos... daí eu falava da bexiga... aí eu resolvi fazer umas continhas... a quantidade inicial e a final... Quando tem conta já tem gente que começa a dormir, ouvir música...Se eu estou falando como funciona o movimento da bexiga, eles participam, mas quando eu estou fazendo uma conta no quadro, eles não participam tanto... na hora que matematizou, já começa (sic) a perder a atenção!

O episódio acima demonstrou o quanto a experiência mal sucedida da aula anterior (realização da atividade com os skates, que foi finalizada muito rapidamente) contribuiu para que $\mathrm{R}$ apresentasse um maior cuidado na elaboração do planejamento da aula atual, fato este, claramente relacionado ao temor de que a aula fosse encerrada antes do tempo.

O trecho relatado, entretanto, nos permite inferir acerca de elementos elaborados pelo licenciando acerca da utilização de matemática no Ensino de Física. Apesar de a professora colaboradora solicitar a não utilização de cálculos com os alunos, R, no momento da aula decidiu por realizar tal tipo de intervenção, notando uma grande queda 
na participação dos alunos devido à utilização da matemática (“Quando tem conta já tem gente que começa a dormir, ouvir música...”).

O fato já descrito, gerador de uma instabilidade (perda do interesse por parte alunos) naquele momento e possível demonstrador da existência de um conflito de natureza sociocognitiva (CASTORINA, 2008) pelo estagiário, ilustra o reforço de possível visão de ensino, onde a Física, para manter o interesse e motivação dos alunos, deveria ser ensinada sem a utilização de matemática. $O$ mesmo episódio também reforça a postura do licenciando em defender a ênfase pura na explicação sobre o fenômeno durante as aulas, pois estes conseguiriam manter os alunos interessados ("Se eu estou falando como funciona o movimento da bexiga, eles participam...”).

Os relatos citados apontariam, em nosso ponto de vista, para uma possibilidade de alteração na dimensão conteúdo dos conhecimentos pedagógicos de conteúdo a serem desenvolvidos por $\mathrm{R}$, que poderia efetuar a escolha e aprofundamento de temas físicos em função do grau de matematização exigido por cada tópico. Tal proposição nos parece, de fato arraigada no tocante aos conhecimentos de conteúdo desenvolvidos por R, haja vista que tal fato foi repetido em seu portfólio, entregue após o término das atividades de estágio:

(Port)

$R$ : É recomendada a não utilização da matemática durante as aulas...constatamos que os alunos perderiam interesse na discussão.

Por outro lado, a prática do estágio com ênfase na investigação (ABIB, 2010) e na realização de experimentos e demonstrações parece também ter validado positivamente, para o estagiário, a possibilidade de que tais tipos de atividade motivariam os alunos a se interessar pelo conteúdo abordado:

(Ent)

R: Para mim, parece fácil montar uma problematização com uma experiência...você problematiza, aí vai dando condições para o aluno entender, e aí, você parte para a próxima problematização... você tinha uma problematização grande e vai diminuindo para a particular. 
(Port)

R: Quando chamamos os alunos para construção do experimento, eles participam mais.

Neste ponto, salientamos a importância dada pelo estagiário à questão da problematização no início do tratamento de tópicos relativos à Física. Tal visão, frequentemente abordada nas aulas de Metodologia do Ensino de Física II, nos parece ter sido validada pelo futuro docente, sendo, reiteradamente, citada em suas colocações. Tal modo de ver o ensino, enquadrada nas dimensões pedagógica e de conteúdo de seu PCK, possibilitaria ao licenciando, em práticas futuras, a utilização deste tipo de metodologia, que tem um caráter mais genérico, não sendo exclusividade do conteúdo abordado pelo grupo no estágio.

Nos episódios acima, também podemos notar a importância dada por $\mathrm{R}$ à utilização da experimentação no Ensino de Física. Tal concepção, também enquadrada por nós na dimensão pedagógica dos PCK elaborados, foi alicerçada pelas condições das dimensões do contexto de realização do estágio, onde o licenciando se deparou com alunos que, segundo seu relato, efetivamente participavam mais de aulas envolvendo experimentações. Assim como a questão da problematização, as metodologias envolvendo experimentações acabam por se tornarem gerais, não sendo relacionadas unicamente ao conteúdo de quantidade de movimento abordado pelo estagiário.

Dessa forma, pode-se observar, com base nos trechos analisados, a elaboração de um novo Conhecimento Pedagógico de Conteúdo por parte do estagiário nesta etapa específica de seu trajeto - a utilização da matemática durante as aulas de Física poderia estar associada com a indisciplina nos alunos, que pode ser contornada com a realização de perguntas sobre o conteúdo para os alunos mais falantes - conhecimento este, mais uma vez, embasado na experiência do próprio estagiário R que, através de repertórios anteriores, baseados fortemente em modelos de ex-professores de sua educação básica criou uma forma própria de enxergar a questão disciplinar no contexto da sala de aula, aliando estratégias pedagógicas específicas, juntamente com uma forma peculiar de analisar o conteúdo físico a ser abordado.

Salientamos, entretanto, que, de acordo com a visão de Ball (2008), o PCK criado é específico para o contexto em tela, influenciado por elementos socioculturais 
do momento vivido pelo futuro professor, podendo sofrer alterações no decorrer da futura trajetória profissional do licenciando.

Tal conjunto de informações, juntamente com a classificação proposta por GessNewsome (1999), nos permite inferir que o PCK gerado encontra-se em um caráter Transformativo. A seguir, exporemos o esquema ilustrativo da situação ocorrida com o estagiário R.

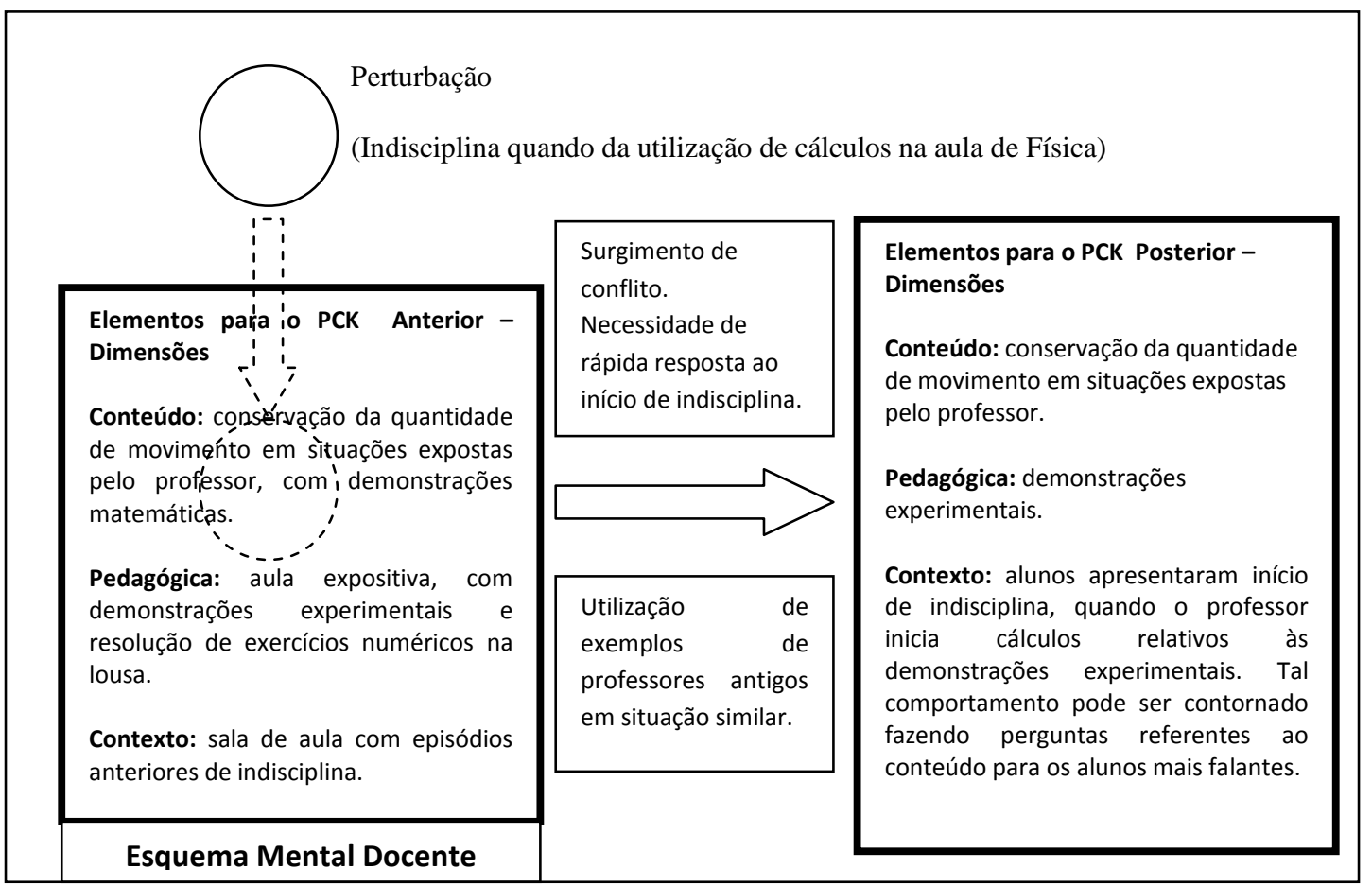

Fig.13 -Esquema de Caminho Criativo Gama do Grupo I

Novamente, verificamos que a perturbação é assimilada pelo sistema de conhecimentos docentes, porém o esquema atual não é suficiente para a resolução do conflito instaurado. $\mathrm{O}$ ambiente da sala de aula onde está inserido o estagiário, que começa a perder o interesse quando se iniciam cálculos sobre o fenômeno abordado, exige uma rápida resposta à perturbação surgida, fazendo com que o futuro docente, novamente, recorra a exemplos bem sucedidos de seus ex-professores submetidos à situação similar, buscando prioritariamente sua sobrevivência (HUBERMAN, 1992).

A seguir, abordaremos episódios de criação do Grupo I, ainda com conduta gama, ocorridos durante o planejamento de intervenções futuras, ou seja, fora do ambiente da sala de aula. 


\subsubsection{Aprendendo Com o Que Não Deu Certo}

Nas últimas reuniões de supervisão e na realização das entrevistas finais, procuramos abordar de forma mais enfática, com os estagiários, as possíveis alterações que seriam feitas no projeto do estágio, em caso de uma nova aplicação. Tal questionamento, longe do ambiente da sala de aula, e sim, como reflexões para futuros planejamentos, nos forneceria elementos que poderiam acenar para a elaboração de novos PCK surgidos face aos imprevistos ocorridos.

Foi realizado, em um primeiro momento, após o término das atividades de estágio, um delineamento sobre quais habilidades o licenciando julgava fundamentais para um professor de Física atuar em sua profissão:

(Ent)

$R$ : Eu tenho uma ideia de conjunto... tem que saber estas estratégias pedagógicas, como tratar o aluno, como tratar a sala como um todo... tem que saber articular um assunto ali, na hora, com alguma coisa do cotidiano deles, muito rápido... porque você consegue segurar o interesse deles... eu já notei isso... acho que a melhor forma de combater a indisciplina é essa... manter o aluno interessado... fazer com que os alunos associem a aula de Física a uma experiência boa... que eles queiram participar.

Neste relato, o futuro professor, através de suas práticas já realizadas ("Eu já notei isso...”) aponta para a importância dos conhecimentos pedagógicos (chamado por ele de estratégias pedagógicas) e do contexto (apontado por ele como saber "tratar o aluno...tratar a sala como um todo"), fatores que indicam uma possível elaboração de PCK pelo estagiário, nos moldes daquele proposto por Shulman \& Shulman (2004). Tais elementos corroboram com aqueles já tratados na literatura da Educação (KIND, 2009), onde, uma boa formação inicial, além de prática pedagógica, fornece aos licenciandos condições emocionais de atuar no ambiente da sala de aula, condição esta, a nosso ver, alcançada por $\mathrm{R}$, ao citar a importância do tratamento adequado aos alunos e à sala como um todo.

O trecho acima também aponta para uma concepção no tocante às suas criações. $\mathrm{O}$ próprio estagiário, provavelmente devido à série de imprevistos vividos em sua trajetória no estágio, tomou consciência da necessidade de criações rápidas no momento da prática, visando à continuidade do controle da turma ("tem que saber articular um 
assunto ali, na hora, com alguma coisa do cotidiano deles, muito rápido... porque você consegue segurar o interesse deles...”). A elaboração desta estratégia de criação na prática docente pode ser corroborada com o depoimento de $\mathrm{R}$ em seu portfólio:

(Port)

R: O maior imprevisto foi os alunos não participarem da aula $e$ fazerem barulho... isso foi contornado colocando-se questões mais corriqueiras dos alunos, como o facebook e o jogo de ontem... Os alunos aumentavam, quase que instantaneamente, o grau de participação.

Nesse relato, $\mathrm{R}$ acabou por estabelecer, em convergência com os episódios já analisados, a visão de que, na prática de sala de aula, a resposta ao imprevisto, que pode vir, por exemplo, da queda de interesse da turma e, conseqüente indisciplina, deve ocorrer de forma rápida e eficaz, com a utilização da exposição de modelos já conhecidos, no caso, as situações cotidianas que, segundo sua experiência de estágio, conseguiria retomar a atenção dos alunos desatentos.

Vale ressaltar, neste momento, que tais modelos, conforme já analisado nos tópicos anteriores, acabava por se relacionar com atitudes de ex-professores dos estagiários, quando de sua passagem pela educação básica.

Vale ressaltar que, juntamente com a importância conferida às dimensões de contexto e pedagógica na formação de um bom professor de Física, a questão do conteúdo também é abordada por $\mathrm{R}$ em sua entrevista final e durante a apresentação dos resultados de seu projeto durante a aula de Metodologia do Ensino de Física II.

(Ent)

R: Eu acho que a Física "hard" "é importante, porque quando você sabe a Física hard, você consegue explicar com clareza algumas ideias fundamentais, você transmite confiança ao aluno... tem que saber Física hard...

(Aula)

R: (...)[o professor] tem que saber Física...é importante, eu acho... Facilita a forma como vai fazer as mudanças na aula...

\footnotetext{
${ }^{21}$ Hard: pal. Inglesa. Difícil, pesado. No contexto da pesquisa, o estagiário refere-se à Física como ciência, ensinada nas Universidades e Centros Acadêmicos.
} 
O episódio anterior procura retratar a concepção de R sobre a necessidade do professor de Física apresentar conhecimentos profundos sobre a ciência Física. A elaboração do estagiário é extremamente validada pelas pesquisas da área, como Kind (2009), que aponta a existência de bons $\mathrm{SMK}^{22}$ (conhecimentos do conteúdo) como requisito fundamental para um bom professor na área de ciências. Segundo a autora, a deficiência deste tipo de conhecimento dificulta a realização de mudanças necessárias na aula, bem como identificar, com clareza, possíveis concepções errôneas dos alunos acerca dos temas propostos, fatores estes, fundamentais à elaboração de novas intervenções no ambiente escolar.

Ainda de acordo com a análise do relato do estagiário, o mesmo desenvolve a visão de que um professor com bons conhecimentos de conteúdo consegue uma boa relação emocional com a turma. Na verdade, tal concepção também é abordada e validada pelas pesquisas específicas na área dos Conhecimentos Pedagógicos de Conteúdo (KIND, op.cit., SALAZAR, 2005), onde, o bom SMK, além de trazer autoconfiança ao professor, acaba por transmitir esta segurança ao restante da turma.

Ainda em relação à elaboração dos PCK por parte do estagiário, questionamos a respeito das mudanças que seriam efetuadas no projeto de estágio no caso de uma nova aplicação, conforme exposto abaixo.

\section{(Ent)}

R: Tinha uma atividade dos skates que não rendeu muita discussão, foi muito rápida... a ideia era falar sobre... colocava uma pessoa leve e outra pesada para se empurrarem... o problema é que esta atividade pareceu muito óbvia para eles, não rendeu discussão, foi rápida demais... talvez [em uma nova aplicação do projeto] eu colocasse dois bloquinhos com molas, que nem na graduação... é a mesma coisa, mas fica mais ilustrativo, porque quando eles se empurram, não dá para garantir que a força do empurrão é sempre igual.

$\mathrm{O}$ estagiário $\mathrm{R}$, ao ser questionado sobre possíveis mudanças no projeto de estágio elaborado, cita, unicamente, a aula onde ocorria a experiência dos skates. Tal intervenção, de fato, foi palco de imprevistos e instabilidades face à rapidez com que ocorreu, que se desencadearam face à existência de uma lacuna nos esquemas mentais

\footnotetext{
${ }^{22}$ Subject Matter Knowledge
} 
do licenciando naquele momento, fazendo com que o mesmo não conseguisse prosseguir a aula de maneira coerente, inclusive, encerrando-a antes do tempo.

Tal atividade, portanto, demonstrou-se marcante para o estagiário, haja vista que na aula seguinte, o planejamento já foi efetuado com mais esmero, visando à adequação da intervenção com o tempo da aula.

Com base nestes fatos, podem-se vislumbrar neste episódio, elementos que apontam para a sequência de imprevistos da aula original, que, inicialmente geraram uma perturbação lacunar, por parte do licenciando. Tal lacuna, em momentos de reflexão posteriores, aponta para a geração de uma perturbação conflitiva com características de se dirigir para uma conduta gama, ou seja, significativa para o futuro professor, com existência de conflitos (PIAGET, 2002) e necessidades (VIGOTSKY, 2009 e RIGON, 2009) criativas docentes capazes de levar o estagiário a procurar em seus repertórios anteriores possibilidades de resolução da situação.

Nesse ponto, vale salientar a importância dos elementos socioculturais (VIGOTSKY, 2001) citados pelo estagiário, que se demonstraram importantes nesta nova elaboração, como a obviedade do experimento naquele contexto, bem como a ausência de discussão prevista para aquela situação. Desse modo, podemos estabelecer que o conflito provocador da conduta gama citada apresenta elementos que permitem caracterizá-lo em uma natureza sociocognitiva (CASTORINA, 2008).

Tal conflito, devido à "aula dos skates" citada pelo licenciando, aponta, portanto, para uma reelaboração do conhecimento pedagógico de conteúdo relativo à intervenção didática em tela. O futuro docente, preocupado com a rapidez do experimento proposto, procura uma alteração da abordagem do mesmo, trocando a participação dos alunos pela possibilidade de utilização de um experimento montado a partir de blocos e mola, realizado por ele durante seu curso de graduação.

Dessa forma, o estagiário, em sua visão, teria maior controle da demonstração, haja vista não ser mais necessária a troca de alunos que ocupavam os skates. De acordo com o licenciando, tal troca seria, inclusive, mais correta, pois garantiria que a força trocada entre os móveis, quando do seu lançamento, seria sempre a mesma, podendo gerar relacionamentos mais fidedignos entre a massa e velocidade dos corpos envolvidos. 
Os fatos acima descritos trazem, portanto, novos e importantes indícios da criação de elementos na dimensão conteúdo do conhecimento pedagógico de conteúdo relativo a esta aula, em particular. Apesar do episódio retratar, mais claramente, a alteração de conteúdo, vale ressaltar que os elementos inerentes ao estágio de $\mathrm{R}$ apontam o contexto da turma como disparador desta necessidade de mudança, tendo em vista que a rapidez com que os alunos realizaram a atividade foi o fator fundamental para a ocorrência da mudança.

Já a dimensão pedagógica, de acordo com a prática declarada de $\mathrm{R}$, apresentou mudanças visíveis mais discretas ("talvez se eu colocasse dois bloquinhos com a mola...é a mesma coisa....[grifo nosso]). O fato de admitir que as atividades são "a mesma coisa" nos possibilita inferir acerca da forma como $\mathrm{R}$ abordará as mesmas, do ponto de vista pedagógico, porém, sem considerar a participação dos alunos. Entretanto, tais alterações, mesmo que pequenas, demonstram a necessidade do futuro professor em trazer intervenções mais corretas, do ponto de vista científico. Dessa forma, a utilização de demonstrações em sala de aula nos mostra que o licenciando vê, de forma positiva, sua utilização em ambiente escolar, reforçando a validação da visão do estagiário a respeito do uso das atividades experimentais em aulas de Física.

A recorrência de $\mathrm{R}$, explicitamente, às dimensões conteudísticas, pedagógicas e contextuais para a elaboração de um novo Conhecimento Pedagógico de Conteúdo - $o$ rigor científico nas demonstrações experimentais, juntamente com a participação dos alunos e utilização de elementos do cotidiano colaboram com a melhor aprendizagem discente - nos permite inferir acerca da criação de um PCK no patamar Integrativo (GESS-NEWSOME, 1999), haja vista que os episódios demonstram a busca independente do estagiário em cada uma das dimensões propostas por Grossman (1990), unindo-as na elaboração de um novo conhecimento docente, conforme buscamos sintetizar a seguir. 


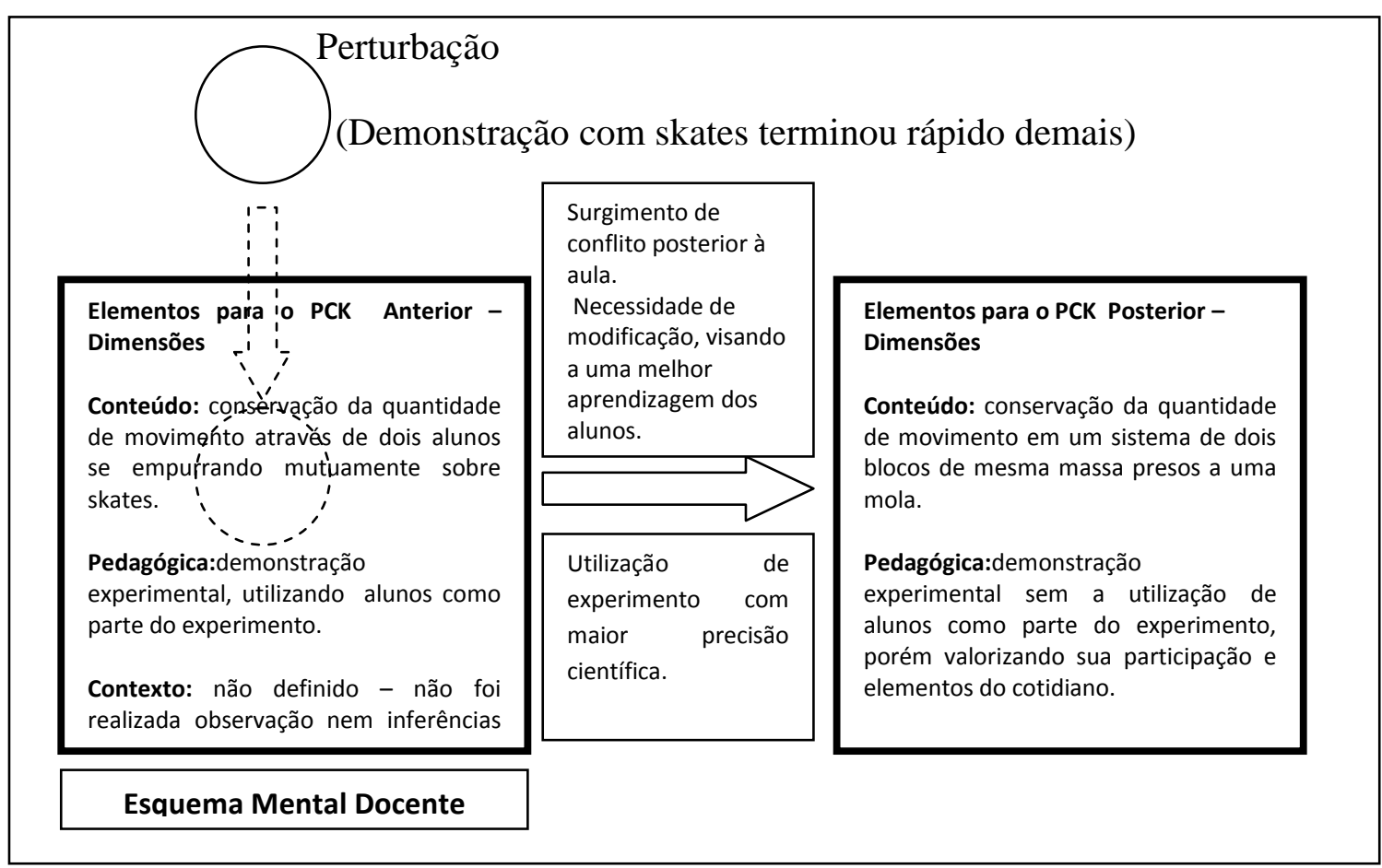

Fig.14 -Esquema de Caminho Criativo Gama do Grupo I

Os fatos representados no esquema anterior buscam, novamente enfatizar que, uma situação de prática docente com características de conduta lacunar por parte do estagiário, em momentos posteriores e com ambiente propício a reflexões sobre sua própria prática, permitiu ao futuro professor rever um momento didático mal-sucedido, utilizando os elementos do insucesso para construção de um novo planejamento, visando a uma melhor aprendizagem dos alunos.

Nesse ponto ressaltamos a importância de mais elementos do entorno cultural (VIGOTSKY, 2001) onde o estagiário encontrava-se inserido, haja vista que os episódios anteriores nos demonstraram que as socializações promovedoras de ZDP nas reuniões de supervisão, bem como o incentivo à utilização de atividades experimentais tratado na disciplina de Metodologia do Ensino de Física II se mostraram relevantes no desenvolvimento do processo de estágio aqui citado.

Desse modo, os episódios analisados nesse tópico apontam para, além da importância das temáticas abordadas na disciplina citada anteriormente, a relevante existência da questão investigativa do processo de estágio aqui realizado, uma vez que a preocupação com a motivação que as atividades experimentais proporcionariam aos estudantes, era o objetivo do viés pesquisa dado pelo grupo de licenciandos em seu projeto de aulas. 
A seguir, procuraremos, a título de comparação, acompanhar a trajetória criativa do Grupo de Estagiários II.

\section{O Grupo II}

\subsection{Sujeitos, Contexto e Trajeto do Estágio}

Assim como já realizado anteriormente com o grupo I, a partir deste ponto, procuraremos analisar a trajetória seguida por um novo grupo de estagiários durante a realização de seu estágio, enfatizando os processos, fatores e elementos que puderam influenciar nas criações de seus conhecimentos pedagógicos de conteúdo.

Conforme exposto no capítulo anterior, os integrantes do grupo II, aqui identificados pelas letras $\mathrm{A}, \mathrm{L}$ e $\mathrm{W}$, também frequentavam regularmente as aulas da disciplina "Metodologia de Ensino de Física II", bem como as reuniões de supervisão de periodicidade semanal.

Os estagiários L, A e W, quando da pesquisa, apresentavam 21 anos de idade, sendo alunos do último semestre do curso de Licenciatura em Física da Universidade de São Paulo. Todos os licenciandos declararam que o curso que realizavam havia sido sua primeira opção no vestibular, tendo esta opção sido feita em virtude da facilidade e gosto que possuíam pela disciplina Física durante o ensino médio.

Assim como ocorrido no grupo I, os sujeitos analisados no grupo em tela também não apresentavam experiência profissional, sendo a experiência relacionada à docência resumida a aulas particulares ou aos próprios estágios de observação realizados, até então, nas disciplinas pedagógicas da Faculdade de Educação da Universidade de São Paulo.

Salientamos que, diferentemente do Grupo I, onde cada integrante ministrava aulas no estágio em períodos diferentes do outro, este conjunto de estagiários ministrou todas as aulas juntos, em duas turmas do primeiro ano do ensino médio, sendo o projeto de estágio realizado em uma escola da rede pública estadual, situada no município de São Paulo. A instituição de ensino onde se realizaria o projeto, apesar de frequentemente, receber estagiários da Universidade de São Paulo, não provocou uma boa primeira impressão aos licenciandos, conforme exposto abaixo. 
(Port)

W: eu já tinha feito estágio lá no semestre passado...

(Port)

A: Quando chegamos na escola, fomos direto falar com uma das professoras de Física. Ela não nos recebeu muito bem... assim que nos viu, já disse que a escola não precisava de mais estagiários... se a gente quisesse, era para voltar no sábado e procurar outro professor.

Apesar do relato acima, o grupo II, após insistentes tentativas, conseguiu que um dos professores de Física da escola os aceitassem como estagiários. Tal docente ministrava aulas para duas turmas do $1^{\circ}$ ano do ensino médio, sempre às sextas-feiras no período da tarde e, segundo seus relatos, a frequência dos alunos e seus aproveitamentos não eram muito altos.

Desta forma, aqui se revela uma faceta do contexto das turmas onde os estagiários ministrariam suas aulas; a maioria dos alunos, segundo os próprios licenciandos, praticamente, não comparece à escola, além de ser apontada, na visão do professor colaborador, uma falta de interesse por falta dos discentes, podendo ser relacionada com episódios de indisciplina, que, mais tarde, seriam constatados e reiterados pelos licenciandos, conforme pode ser verificado abaixo.

(Sup2-20:05)

A: A gente já observou a primeira aula...três prestam atenção...

(Ent)

L: Foi um desafio... até hoje eu não tinha pego uma "turmaproblema"... foi a primeira turma que, realmente, deu trabalho para mim... era muita indisciplina... muito desrespeitoso, várias vezes tinha aluno pulando o muro da escola, sendo preso pela polícia.

Além do quadro de indisciplina, as primeiras interações entre os estagiários e o contexto das turmas permitiram aos mesmos constatar que o professor colaborador, visando ao controle disciplinar dos alunos, avaliava-os constantemente, realizando "exercícios para nota". 
(Sup2 - 20:49)

L: O professor entrou na sala, escreveu a prova na lousa...ele recolheu, já corrigiu e falou as notas... tinha uns 27 zeros...

(Port)

W: Os alunos já estavam acostumados com esse controle...ninguém reclamava.

(Ent)

L: ...tudo eles (alunos) queriam saber de nota, tudo na base da nota... o professor chantageava o aluno com a nota.

O controle de notas por parte do professor colaborador, referido neste último episódio, acaba se transformando em uma estratégia corriqueira do docente ("tudo eles (alunos) queriam saber de nota, tudo na base da nota”) na manutenção da ordem da sala. É neste quadro de aparente desordem, indisciplina e estudantes que realizam suas atividades exclusivamente se receberem nota por elas, que o grupo II de estagiários iniciou suas atividades de estágio no ambiente escolar.

Conforme tratado no capítulo anterior, na essência do processo de estágio de cunho investigativo, a intervenção do futuro professor em sala de aula não se resume a uma sequência didática que será aplicada aos alunos (dimensão ensino), mas também, deve relacionar esta prática com a solução de um problema de pesquisa referente ao Ensino de Física (dimensão pesquisa).

Desta forma, o grupo II, no tocante ao viés do ensino, apresentou como tema norteador de seu projeto o estudo de princípios básicos de Astronomia para os alunos do ensino médio, enquanto que, a dimensão da pesquisa pretendia analisar os métodos de avaliação utilizados e sua relação com a aprendizagem discente. Diante deste questionamento, os licenciandos, em sua sequência de aulas, utilizaram diferentes formas de avaliação das atividades propostas aos alunos, visando a um relacionamento entre a explicitação das ideias dos alunos, características de suas aprendizagens e seus respectivos métodos avaliativos.

A escolha de conteúdos relacionados à Astronomia para serem trabalhados no ambiente escolar parece ter se originado em disciplinas cursadas anteriormente pelo estagiário L. 
(Ent)

L: A gente ficou pensando o que seria interessante para os alunos... Astronomia é um bom tema para começar [o estudo da Física]... meu professor de Conceitos de Astronomia do IAG ${ }^{23}$ já falava isso... tinha bastante coisa que saia na TV, jornais... é do dia a dia dos alunos...

Em corroboração com Piaget (op.cit.) e Vigotsky (op.cit.), notamos, assim como já ocorrido no grupo I, utilização de repertórios anteriores e experiências vividas como base da criação do projeto de intervenção em sala de aula. Neste caso, a influência de um ex-professor do estagiário L nos pareceu fundamental para a escolha deste licenciando pelo conteúdo de Astronomia.

Tal fato também é corroborado com a escolha do estudo de métodos avaliativos pelos integrantes do grupo, relacionado ao viés pesquisa do processo de estágio investigativo. Na mesma semana que os estagiários decidiram por essa temática, o mesmo conteúdo havia sido abordado nas aulas de Metodologia do Ensino de Física II.

Com base no conteúdo escolhido e nos métodos pedagógicos estipulados pelos estagiários, estes começam a estabelecer uma sequência didática mais detalhada dos conteúdos a serem trabalhados com a sala de aula, conforme pode ser verificado nos relatos do estagiário $\mathrm{W}$.

(Sup2-6:32)

W: ...uma aula de conceitos básicos de astronomia, falar sobre as medidas em astronomia... fazer um planisfério com eles... a terceira aula, a gente pensou em trabalhar vida extraterrestre... a gente pensou em trazer algum artigo para eles discutirem... depois vem o jogo de astronomia.

Pesq: E já pensaram como vai ser este jogo?

W: Na turma de prática ${ }^{24}$ o pessoal já elaborou um jogo do tipo $U_{n o}^{25}$, com cartas...

\footnotetext{
${ }^{23}$ Disciplina optativa oferecida aos licenciandos em Física pelo Instituto de Astronomia e Geofísica da Universidade de São Paulo.

${ }^{24} \mathrm{O}$ estagiário refere-se à disciplina de Prática de Ensino, ministrada aos licenciandos em Física com objetivo de aproximá-los das estratégias específicas do ensino desta disciplina.

${ }^{25}$ Jogo de cartas, onde cada uma delas apresentaria o nome de um planeta e suas características, tais como temperatura, diâmetro, distância até o Sol, etc. O objetivo é confrontar as informações de sua carta com as de seu oponente, vencendo aquele que apresentar o maior valor.
} 
Os trechos anteriormente transcritos, além de demonstrarem um crescente envolvimento do grupo com os conteúdos específicos de Astronomia a serem ministrados, apontam, mais uma vez, para a utilização de repertórios anteriores (PIAGET, 1972 e VIGOTSKY, 2009) por parte dos estagiários para criação de suas estratégias ("Na turma de prática, o pessoal já elaborou um jogo do tipo Uno, com cartas...”). A utilização de uma atividade lúdica já utilizada anteriormente, porém com adaptações específicas para o conteúdo de Astronomia, apontam para um nível criativo de natureza combinadora (VIGOTSKY, op.cit.).

Desta forma, a partir deste momento, a sequência a ser trabalhada pelos estagiários já se encontrava organizada. Portanto, na $1^{\mathrm{a}}$ aula, os futuros professores trabalhariam, com os alunos, alguns conceitos básicos de Astronomia, enfatizando as medidas nesta área científica e a nomenclatura dos corpos celestes.

A segunda aula do grupo enfatizou o estudo das estações do ano e das fases da Lua, sendo que os estagiários levariam esferas de isopor para representar a Terra, o Sol e a Lua, além de uma lanterna para simular os raios luminosos solares. Salientamos, nesta aula específica, a origem desta estratégia, de acordo com o estagiário L.

(Ent)

L: ... as fases da Lua... quando eu vi na aula de Conceitos de Astronomia... o professor tinha feito coisas do tipo... acabou vindo daí.

Novamente, é possível constatar a importância dada, pelo estagiário L, à disciplina de Conceitos de Astronomia, cursada durante sua graduação. Pode-se notar tal influência quando, o licenciando traz a simulação realizada pelo seu ex-professor para ambiente de sua sala de aula (“... eu vi na aula de Conceitos de Astronomia... o professor tinha feito coisas do tipo"), remetendo-nos, mais uma vez, à utilização dos repertórios e experiências anteriores com adaptações ao contexto atual, inferindo-se um nível criativo de natureza combinadora (VIGOTSKY, op.cit.).

A terceira aula a ser ministrada pelos licenciandos envolveria a utilização de uma atividade lúdica denominada Jogo Uno, onde os alunos receberiam cartas contendo o nome dos planetas e estrelas, bem como suas características físicas (temperatura, diâmetro, distância ao Sol, etc). O objetivo da atividade é que os estudantes, jogando em duplas, selecionassem cartas, aleatoriamente, e comparassem cada uma das informações 
contidas nelas, ganhando aquele que possuir as características acima descritas com maior valor numérico.

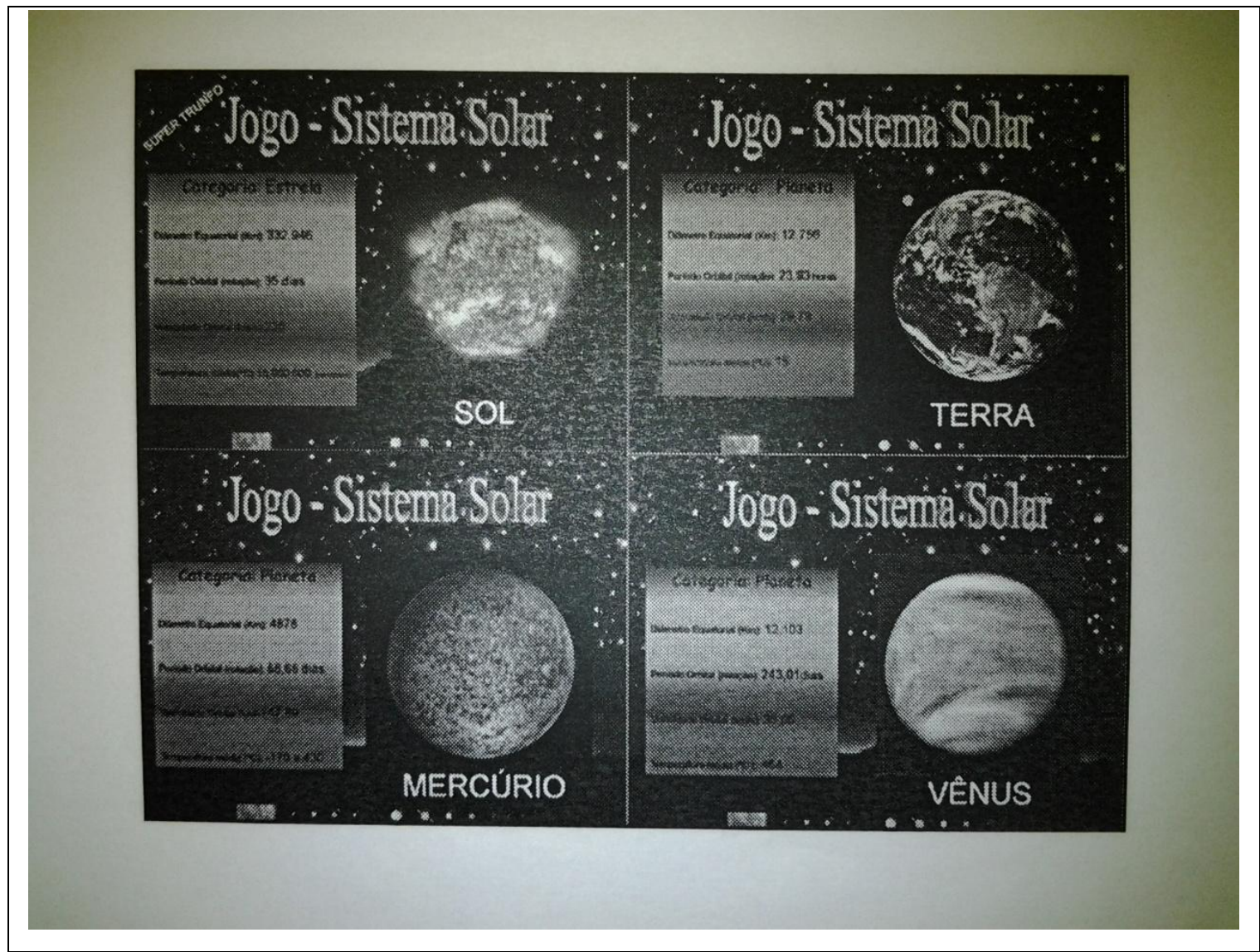

Fig.15 - Exemplos das cartas utilizadas no jogo (nos quadros à esquerda dos astros, encontramse os respectivos valores de suas características físicas)

A quarta aula proporia uma discussão entre os estudantes acerca da existência de vida extraterrestre, efetuando, para tanto, a separação da sala em dois grupos, que defenderiam ou não a existência de tal tipo de vida, baseados na leitura de artigos científicos sobre o tema. Desta forma, seria criado uma espécie de júri acerca dos fatos, propiciando um espaço de discussão na sala de aula.

Com este planejamento realizado, o grupo II iniciou suas atividades do processo de estágio nas salas de aula, ficando sujeitos às diversas perturbações que interferirão na elaboração de seus caminhos criativos para a resolução das mesmas. A seguir, iniciaremos a categorização destas situações de acordo com o tipo da instabilidade inicial surgida, bem como o desenvolvimento criativo dado pelos estagiários após a constatação da mesma.

Na sequência, apresentamos um quadro-síntese das principais características do Grupo de Estágio II, até aqui apresentadas. 
Estagiários: A, L e W..

Idades: 21 anos.

Experiência em relação à docência: aulas particulares.

Situação Acadêmica: freqüentam o $8^{\circ}$ semestre da Licenciatura em Física. Concluíram todas as disciplinas da grade curricular relativas ao Ensino de Física.

Escola onde realizou o estágio: Pública Estadual, situada no município de São Paulo.

Série onde se realizou o estágio: 1o ano do Ensino Médio.

Professor colaborador: após muitas tentativas, um professor de Física da escola, que estudou na Universidade de São Paulo, aceita os estagiários. Segundo estes últimos, tal docente não estimula a participação dos alunos em sua aula, efetuando o controle disciplinar mediante ameaças com relação a descontar nota dos alunos .

Projeto de Estágio (viés ensino): abordar conceitos de astronomia em aulas que buscassem a participação do aluno.

Projeto de Estágio (viés pesquisa): Verificar vários métodos de avaliação, visando a demonstrar aquele(s) que os estudantes conseguem expor melhor suas ideias.

Origem do Projeto: os estagiários acenam a origem do projeto à influência de professores da graduação que incentivavam o uso de Astronomia nas aulas de Física. A origem da vertente pesquisa aponta para discussões ocorridas nas aulas de Metodologia do Ensino de Física II, onde foram discutidas formas não tradicionais de avaliação.

\section{Sequência didática:}

Aula 1 - Abordagem de princípios básicos de astronomia, tais como as unidades de medida utilizadas nessa área científica, definições dos corpos celestes (planetas, satélites, estrelas, asteróides, meteoros e cometas). Ao término da aula os estagiários solicitavam aos alunos que respondessem um questionário sobre os temas tratados.

Aula 2 - Discussão sobre a existência das fases da Lua, buscando explicá-las através de uma demonstração em escala menor, utilizando bolas de isopor para representarem a Lua e a Terra, bem como uma lanterna para simular os raios solares. Ao término da aula, os estagiários, novamente solicitaram aos alunos que respondessem um questionário sobre os conceitos tratados. 
Aula 3 - Atividade lúdica envolvendo um jogo de cartas, onde cada uma delas possuía a representação de um corpo celeste (planetas, Sol, Terra e Lua), além de suas dimensões e características físicas, como temperatura da atmosfera e de sua superfície. Os alunos jogariam em duplas, e, de acordo com a característica física em questão, ganharia aquele que obtivesse o maior valor.

Aula 4 - Os estagiários utilizam um problema aberto (Quais condições são necessárias para a existência de vida extraterrestre?) para a discussão de tema ligado à astronomia. A metodologia empregada constava de dividir a sala em dois grupos, um defendendo e o outro refutando a existência de vida extraterrestre. Tal atividade foi chamada pelos licenciandos de "júri aberto". Ao final da mesma, os futuros professores solicitaram aos alunos que desenhassem, em uma cartolina, os argumentos que sustentavam suas opiniões.

Aula 5 - Esta aula destinava-se a uma avaliação geral do curso dado pelos estagiários. Para tanto, estes solicitaram aos alunos que desenhassem ou escrevessem em uma cartolina os conceitos aprendidos durante as aulas.

Quadro 2 - Síntese da caracterização do Grupo de Estágio II

A seguir, iniciaremos a análise dos Caminhos Criativos percorridos pelo Grupo II, a começar por aqueles determinados pela conduta alfa.

\subsection{O Caminho Criativo Alfa}

A título de síntese, para Lima Filho e Rebouças (1988), ao analisarem as perturbações inseridas por Piaget em sua Teoria de Equilibração, as condutas do tipo alfa iniciam-se com perturbações que geram equilíbrios instáveis e restritos no sujeito, sendo parcialmente compensados. Desta forma, se a perturbação é fraca, uma simples modificação do indivíduo pode garantir a reequilibração. Entretanto, se a perturbação é mais forte, o sujeito pode negá-la ou afastá-la.

$\mathrm{Na}$ análise do trajeto de estágio do Grupo II, foi possível a localização de episódios de interesse acadêmico caracterizados, principalmente, pela negação de perturbações por parte dos licenciandos, procurando manter seus planejamentos iniciais, conforme ilustrado a seguir, onde a participação dos alunos desencadeou tal instabilidade. 
5.2.1. A Participação dos Alunos

O grupo de estagiários II, após sofrer algumas perturbações no ambiente de estágio, que serão tratadas nos tópicos posteriores deste trabalho, optou por realizar uma intervenção didática relativa à sua segunda aula do projeto de estágio, onde a participação dos alunos era fundamental.

A origem de tal intervenção se deu após o contato inicial dos licenciandos com os alunos em sua primeira aula, que tratava sobre os conceitos básicos de astronomia. $\mathrm{O}$ grupo de futuros docentes solicitou que os estudantes respondessem um questionário sobre os conteúdos abordados durante esta primeira aula. Para surpresa dos licenciandos, o resultado não foi como esperado:

(Sup3 - 11:17)

A: Parecia que a aula tinha sido legal, mas depois a gente viu que tinha uns poucos bons [resultados]... a maioria copiou, entregou em branco... eles não entenderam...

(Port)

A: As avaliações da primeira aula nos assustaram um pouco, nos fazendo pensar em porque eles [os alunos] não estavam aprendendo. A gente tinha que mudar nossa aula.

(Port)

L: A indisciplina atrapalha, também. Estamos tentando tornar as aulas mais interessantes, mas os alunos fazem muito barulho.

Os episódios acima demonstram a preocupação do grupo de licenciandos com a aprendizagem dos estudantes, porém, tais preocupações serão abordadas de forma mais aprofundada nos tópicos posteriores deste trabalho. Nesta etapa, procuraremos focar a análise na intervenção seguinte, que será realizada pelos licenciandos após tais perturbações.

A criação elaborada pelo grupo II, neste momento, tem sua origem remetida aos conhecimentos adquiridos na disciplina "Metodologia do Ensino de Física II":

(Port) 
L :... conforme já tínhamos visto nas aulas [de Metodologia do Ensino de Física II], a participação dos alunos é fundamental... vamos utilizar três alunos para explicar as fases da Lua, chamando um novo trio para cada nova fase da Lua.

(Port)

A: Tentaremos deixar a aula mais dinâmica, usando alunos para representar os astros..na primeira aula, percebemos que os alunos conversam muito, então já pensamos em atividades de caráter mais lúdico.. para eles ficarem mais entretidos.

Desta forma, os estagiários, na tentativa de resolver a insatisfação anterior e suprir a necessidade de melhor aprendizagem dos alunos já latente em seus relatos, iniciam a segunda aula do projeto com o intuito de utilizar a participação dos estudantes como provável fator que favoreceria a apropriação dos conteúdos trabalhados.

Nesta aula, foco da análise neste tópico do trabalho, o objetivo principal era demonstrar a ocorrência das fases da Lua através da utilização de esferas de isopor que representariam os astros envolvidos (Sol, Terra e Lua), além de uma lanterna que simularia os raios solares. Conforme exposto anteriormente, os licenciandos chamariam alunos da sala de aula para segurarem as esferas, representando os corpos celestes.

Durante a intervenção, entretanto, a estratégia criada parece não surtir o efeito desejado:

\footnotetext{
(Sup3-18:47)

A: Então... não deu certo... a gente levou o globo [terrestre] com um cabo de madeira no meio e duas bolinhas para representar o Sol e a Lua... e fomos chamando eles [alunos] - "Quem vai ser o sol? Quem vai ser a Lua? Só que deu errado, porque a gente ficou trocando de aluno... a gente perdeu muito tempo.

(Port)

L: ...quando mudávamos a fase da Lua, chamávamos um novo trio.Esta decisão não foi boa... pois eles não se prontificavam a participar. Na segunda turma, utilizamos o mesmo trio durante toda a explicação.
}

A criação da estratégia por parte dos estagiários levou em consideração elementos socioculturais constatados no ambiente da sala de aula. Tais elementos apontavam para o fato de que as turmas eram bastante agitadas, ocorrendo, inclusive, 
episódios de indisciplina. Tal situação fez o grupo inferir, visando uma melhora no ambiente de ensino, que os alunos poderiam gostar do fato de serem chamados para participar mais explicitamente do momento da aula.

Desse modo, as hipóteses de ensino dessa nova elaboração, por parte dos estagiários, era utilizar tais elementos, a princípio antagônicos à aprendizagem e específicos da cultura e contexto daquelas turmas, no auxílio ao aprendizado de seus estudantes, apontando para a instauração de um conflito de natureza sociocognitiva (CASTORINA, op.cit.) Entretanto, o resultado obtido foi exatamente o oposto.

Apesar da prática proposta não ter apresentado o resultado esperado, tal momento, aparentemente, não gerou instabilidades nos estagiários durante a aula, que os fizessem se sentir obrigado a alterar a forma de abordagem do conteúdo durante aquele momento, haja vista que a estratégia, mesmo falha, foi levada até o término da aula.

Desse modo, a instabilidade surgida foi ignorada pelo grupo de estagiários que, mesmo constatando que o tempo didático da aula não estava sendo aproveitado conforme o planejamento inicial, optou por negar tal perturbação, naquele momento, caracterizando uma conduta alfa (PIAGET, 1976) por parte dos licenciandos.

Tal qual ocorrido com o Caminho Criativo Lacunar, pelo Grupo I, os estagiários do Grupo II não efetuaram o desenvolvimento de um novo Conhecimento Pedagógico de Conteúdo, tal quais os modelos apontados por Shulman (1987) ou Shulman \& Shulman (2004).

Entretanto, os futuros professores, após o término da aula, procuraram efetuar uma alteração de estratégia de uma turma para a seguinte, não utilizando tantos alunos para participar da demonstração. Tal fato nos parece apontar para alterações, ao menos, na dimensão pedagógica de seus PCK, estabelecendo limites para uma participação mais intensa dos alunos na explicação do conteúdo. Desse modo, apesar de não ocorrer indícios de novos elementos relativos à criação e ao PCK, explicitamente durante a aula onde ocorreu a conduta alfa, foi possível verificar que os estagiários, após refletirem sobre o ocorrido, acabaram por efetuar modificações em seus conhecimentos para utilização em momentos futuros. Salientamos que tal momento de reflexão foi rápido e ocorreu no intervalo entre as duas aulas (cerca de 50 minutos), após consenso geral entre os integrantes do grupo de que a estratégia não havia sido bem-sucedida. 
No tocante à criação, durante a intervenção didática na primeira turma, verificou-se que a negação da perturbação surgida com a participação dos alunos fez com que os estagiários continuassem o planejamento inicial, tal como foi elaborado, revelando uma proximidade com o patamar reprodutor (VIGOTSKY, 2009) do espectro criativo, seguindo, literalmente, o planejamento proposto, independentemente da perturbação surgida na sala de aula. A seguir, exporemos um esquema ilustrativo que retrata a situação vivida pelos licenciandos durante a conduta alfa ocorrida.

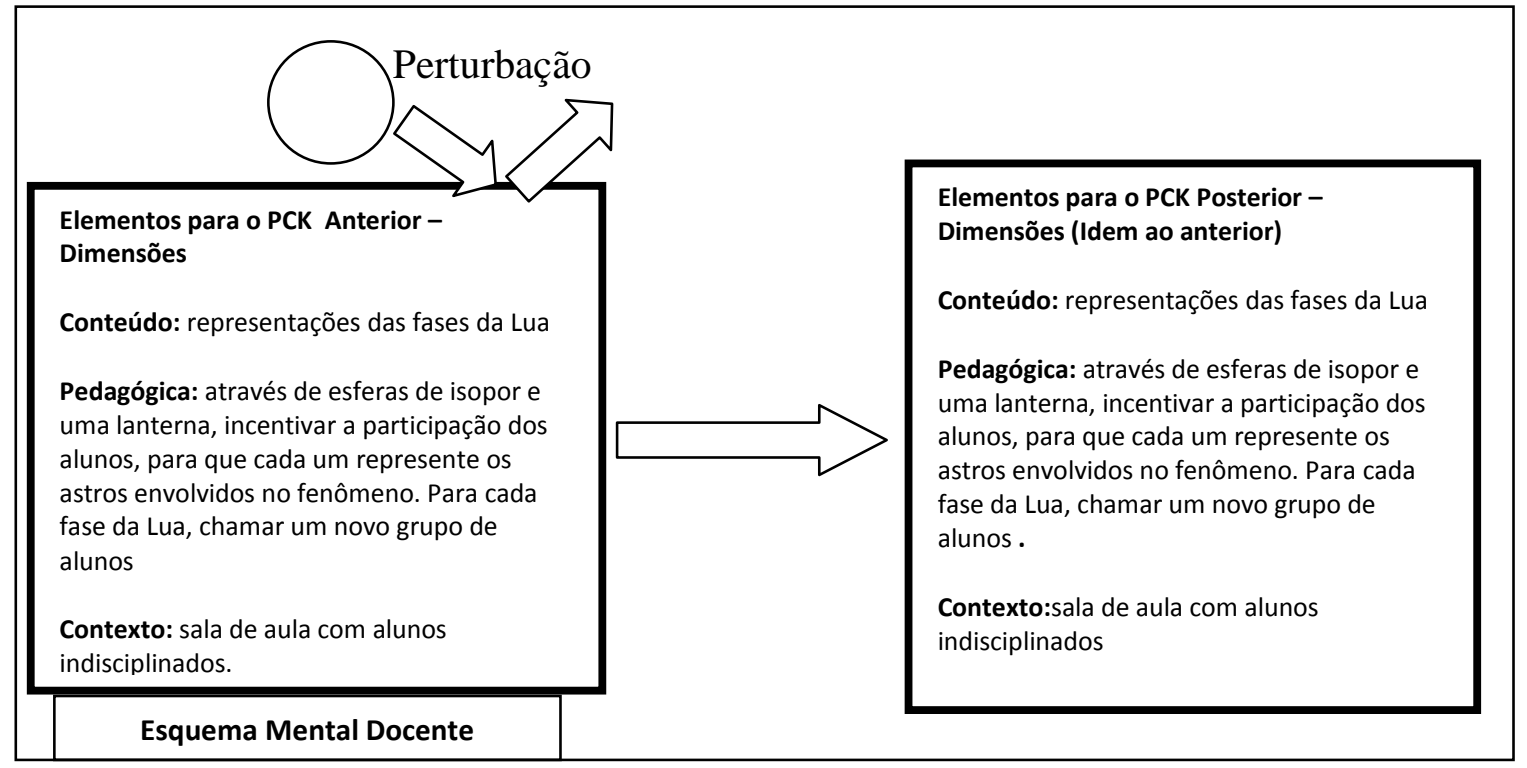

Fig.16 - Esquema do Caminho Criativo Alfa do Grupo II

No esquema anterior é possível verificar que, em uma conduta criativa docente do tipo alfa, a perturbação é negada pelo futuro professor, não conseguindo ser incorporada por seu sistema de conhecimentos. Tal fato acaba por não contribuir por alterações de PCK nesse momento. Salientamos, entretanto, que tal conduta ocorreu no momento da aula, sendo repensada e alterada para aulas posteriores. Desse modo, apesar de não configurar um novo PCK no momento de sua ocorrência, a conduta alfa demonstrou-se, para esse grupo de estagiários, um elemento desencadeador de reorganização da prática docente para momentos posteriores. Conforme explicitado no episódio a seguir, na turma seguinte, ocorreram alterações em relação à metodologia empregada pelos licenciandos.

(Sup3 - 18:47)

A:A gente ficou trocando de aluno... a gente perdeu muito tempo. $\mathrm{Na}$ segunda aula a gente já não fez isso.

L:Na segunda turma, utilizamos o mesmo trio durante toda a explicação. 
Entretanto, ao término desta intervenção, os futuros professores, ao efetuar questionamentos aos alunos, com o intuito de verificar a assimilação dos conceitos abordados, novamente viram resultados longe de suas expectativas.

(Sup3-20:10)

W: Aí eu perguntei...qual ia ser tal fase da Lua e a menina [aluna] lá no fundo me perguntou: mas que horas nasce o Sol?... eu já tinha falado isso umas mil vezes na aula...

(Sup4-7:44)

A: ...quando a gente começou a perguntar, a gente viu que eles estavam chutando, não tinha nada a ver... falavam qualquer coisa, lua nova, lua cheia...

(Port)

A: Passamos alguns questionários...mas não foi bom. A maioria deixou em branco.

A seguir, ilustraremos mais uma situação onde a perturbação externa parece ser ignorada pelo grupo de estagiários. Desta vez, a prática do professor colaborador deflagra a situação de interesse acadêmico.

\subsubsection{A Prática do Professor Colaborador}

Neste tópico, abordaremos as perturbações surgidas no trajeto de estágio dos futuros professores relacionadas à metodologia empregada pelo professor colaborador, relacionando-o, porém, com o quadro de indisciplina dos alunos das turmas onde os licenciandos ministravam suas aulas.

Salientamos que nossa opção por unir, aqui, estas duas vertentes se deu pelo fato de que ambas demonstraram-se relacionadas, ou seja, a postura empregada pelo professor estava intimamente ligada à tentativa de controle do quadro disciplinar dos estudantes, fato este constatado rapidamente pelos licenciandos em suas primeiras interações com as turmas.

Diferentemente do grupo I, o grupo de licenciandos II iniciou o contato com as salas de aula da escola onde o estágio se realizou antes de, efetivamente, ministrarem aulas para estas turmas. A título de observação, os futuros professores assistiram duas 
aulas do professor colaborador nas séries onde ocorreriam suas intervenções, podendo, desta forma, verificar o contexto de ensino e aprendizagem a que estariam envolvidos.

Desde o início da aplicação do projeto de estágio, o grupo de licenciandos se deparou com um quadro geral de indisciplina na sala de aula, conforme relatado já nas primeiras reuniões de supervisão.

(Sup2-20:05)

A: A gente já observou a primeira aula...três [alunos] prestam atenção...

(Ent)

L: Foi um desafio... até hoje eu não tinha pego uma "turmaproblema"... foi a primeira turma que, realmente, deu trabalho para mim... era muita indisciplina... muito desrespeitoso, várias vezes tinha aluno pulando o muro da escola, sendo preso pela polícia.

Além do quadro de indisciplina, as primeiras interações entre os estagiários e o contexto das turmas permitiram aos mesmos constatar que o professor colaborador, visando ao controle disciplinar dos alunos, avaliava-os constantemente, realizando "exercícios para nota".

(Sup2 - 20:49)

L: O professor entrou na sala, escreveu a prova na lousa...ele recolheu, já corrigiu e falou as notas... tinha uns 27 zeros...

(Port)

W: Os alunos já estavam acostumados com esse controle...ninguém reclamava.

(Ent)

L: ...tudo eles (alunos) queriam saber de nota, tudo na base da nota... o professor chantageava o aluno com a nota.

O controle de notas por parte do professor colaborador, referido neste último episódio, acaba se transformando em uma estratégia corriqueira do docente ("tudo eles (alunos) queriam saber de nota, tudo na base da nota") na manutenção da ordem da sala. Entretanto, mesmo com sua utilização, o quadro de desordem generalizada e 
indisciplina nas turmas eram facilmente percebidos pelos licenciandos, conforme relatado a seguir.

(Sup2-27:48)

L: [Na escola onde realizamos o estágio do semestre anterior] tinha problema de disciplina... mas[na escola atual] foi uma bagunça geral... as carteiras não tinham nenhuma organização, cada aluno virado para um lado. Tinha duas alunas encostadas na parede... era como se elas nem estivessem ali...

Os episódios anteriores, portanto, demonstraram que tais momentos de observação se tornaram fundamentais para a forma dada à continuidade dos trabalhos dos estagiários na escola, verificando-se que os mesmos se depararam com diversos comportamentos por parte do professor colaborador que não correspondiam à suas expectativas, conforme se pode verificar, novamente, no episódio abaixo.

(Sup2-21:51)

A: O professor foi aluno [na Universidade de São Paulo]... se formou há pouco tempo, mas você olha para ele... parece que ele já está muito cansado de dar aula, está acabado. A gente chegou e ele falou - "me diz o que vocês querem fazer, o que tiver que aplicar, eu aplico"...sabe... ele não tem um plano de aula...

O trecho acima busca enfatizar o retrato da primeira impressão deixada pelo professor colaborador aos estagiários, refletindo, no ponto de vista dos futuros docentes, um profissional sem motivação e organização para lecionar de forma coerente. Tal fato ainda foi corroborado com as primeiras observações realizadas durante a primeira aula observada pelo grupo.

(Sup2-23:05)

L: Quando a gente foi lá [durante a aula], ele [o professor] demorou dez minutos para começar a aula... ficou sentado em cima da mesa do professor durante vinte minutos e só falando das leis de Newton... não escreveu nada no quadro... ele perguntava e já respondia; nem deixava os alunos irem falando (sic).

Conforme se pode constatar no trecho acima, a impressão deixada pelo professor colaborador foi confirmada pelos estagiários durante sua prática, demonstrando uma postura perante a sala de aula, que desagradou os licenciandos. Segundo o grupo de 
estágio, o professor chegou a demonstrar interesse que os estagiários assumissem integralmente suas aulas.

(Sup2-23:40)

A: ... eu senti que o professor queria empurrar [os conteúdos de Física para os estagiários ministrarem sem qualquer tipo de orientação]... um amigo nosso contou que foi fazer estágio com este professor e ele deixava meu amigo na sala e ia embora... depois voltava, elogiava a aula que ele nem tinha visto e mandava voltar sempre.

Tal posicionamento de aversão à prática pedagógica do professor colaborador foi, reiteradamente, citado no decorrer das reuniões de supervisão com o grupo, neste primeiro momento.

(Sup2-27:26)

W: O professor não ta nem aí com a turma...

(Sup2-27:48)

L: Existiam duas alunas encostadas na parede o tempo todo, durante a aula... quando o professor falou que acabou a aula, elas ficaram do mesmo jeito... tinha sido irrelevante para elas... é totalmente tradicional... [o professor] não tinha motivação nenhuma.

As recorrentes queixas dos estagiários em relação ao comportamento do professor nos pareceu expor uma situação onde a expectativa dos licenciandos no tocante à prática docente confrontou-se com as metodologias utilizadas pelo professor colaborador. Tal confronto é fortalecido pelo entorno cultural (VIGOTSKY, 2001) onde os estagiários estão presentes, mais precisamente, as aulas de Metodologia do Ensino de Física II, onde atitudes como a participação dos alunos, suas concepções prévias e métodos de avaliação não tradicionais foram abordados desde o início de semestre.

Em nosso ponto de vista, tal fato possibilitou a elaboração de uma situação de perturbação de natureza sociocognitiva (CASTORINA, 2008) e em um patamar alfa (PIAGET, 1976) com relação à conduta tomada , onde o grupo de estágio, praticamente, ignora a metodologia empregada pelo professor da escola. Desta forma, os estagiários buscam enfatizar seus modelos pedagógicos que se afastam do modelo docente prevalecente, utilizando-se de repertórios adquiridos nas discussões ocorridas nas aulas 
da disciplina "Metodologia do Ensino de Física II", referentes aos possíveis formatos de interação entre o professor e os alunos, conforme citado anteriormente e comprovado a seguir.

(Port)

W: [Na primeira aula] vamos tentar trabalhar com discussões socráticas, as concepções prévias dos alunos, conforme trabalhamos na aula [de Metodologia do Ensino de Física II].

A primeira aula do estágio, portanto, centrou-se em conversas com os alunos (hábito não existente, até então, na sala de aula), procurando saber suas concepções acerca de Física. Em um primeiro momento, o grupo conseguiu correspondência por parte da sala, conforme exposto a seguir, sugerindo uma validação na prática de suas próprias visões de ensino.

(Port)

A: Os alunos foram bem sinceros: não gostavam de Física por causa das contas e de decorar fórmulas, consequência, com certeza, do ensino tradicional dado pelo professor

(Sup3 - 11:17)

A: a gente passou a fórmula na lousa... aí o pessoal [alunos] reclamou: -fórmula, não!

(Sup3-11:58)

L: Então, primeiro a gente começou com uma discussão básica sobre o que eles achavam que era astronomia, nomes dos planetas, dimensões e distâncias interplanetárias...

No relato acima, fica evidente a insatisfação com a prática do professor colaborador por parte do licenciando, haja vista que a mesma é utilizada, de forma generalizada, para explicar o fato de que os alunos não gostam da disciplina em virtude da utilização da matemática.

Em uma análise mais ampla dos episódios retratados neste tópico, podemos inferir acerca de uma não alteração dos elementos do Conhecimento Pedagógico de Conteúdo por parte dos licenciandos do Grupo II. Dessa forma, os licenciandos mantêm seu PCK - "as aulas devem possuir a participação dos alunos; o professor não deve utilizar a "nota" como moeda de troca ou ameaça". 
Nessa linha de pensamento, os estagiários, ao se depararem com uma situação específica do contexto, onde a prática do professor colaborador não condiz com suas expectativas, enquanto futuros professores, acaba em uma negação da primeira, desencadeando a elaboração formas de abordar o conteúdo de Astronomia, através de metodologias já constantes no sistema de conhecimentos dos futuros professores, ou seja, a aproximação com os alunos.

Desse modo, a elaboração das atividades didáticas a serem realizadas no estágio, ocorridas em um ambiente de planejamento, abrange todas as dimensões de um PCK (do contexto, pedagógicas e do conteúdo) conforme o modelo proposto por Grossman (1990) e, parcialmente, por Shulman \& Shulman (2004). O fato de podermos verificar, separadamente, os momentos em que os estagiários constroem tais dimensões, nos aponta para a elaboração de um Conhecimento Pedagógico de Conteúdo com caráter Integrativo.

O esquema a seguir (Fig.16) busca ilustrar o fato da perturbação representada pela prática de sala de aula do professor colaborador ser negada pelo grupo de estágio como elemento possível a pertencer ao seu sistema de conhecimentos docentes. Tal fato aponta para a manutenção dos elementos de PCK já presentes nos licenciandos, que planejam suas atividades didáticas com base na participação dos alunos durante suas explanações.

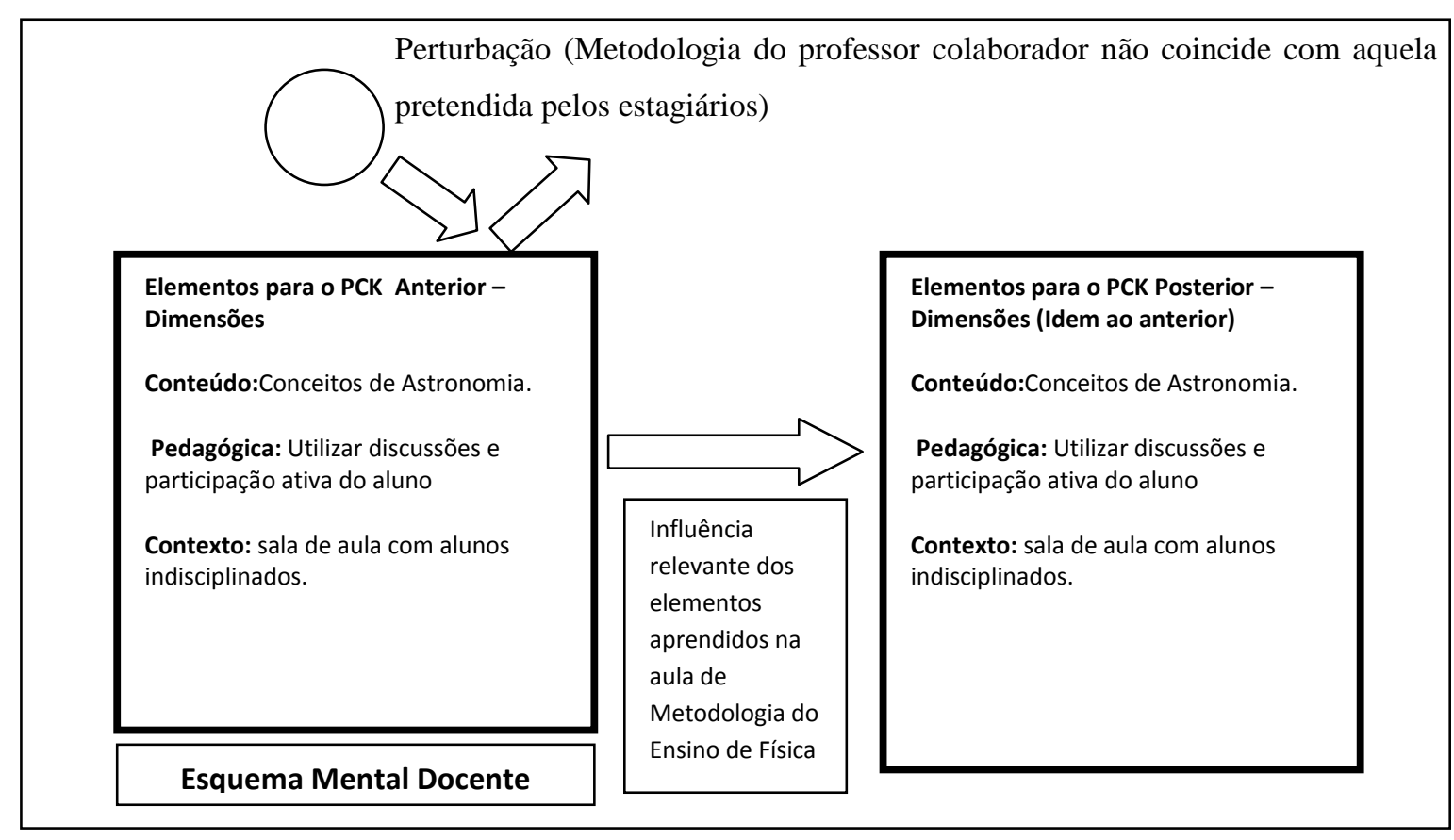

Fig. 17 - Esquema do Caminho Criativo Alfa do Grupo II 
Salientamos, nesse ponto, que, os futuros professores ignoraram o comportamento metodológico do professor colaborador, julgando-o não merecedor de fazer parte de seus esquemas mentais docentes, esses últimos considerados como recipientes onde o profissional do magistério buscaria conhecimentos que julga relevantes para o processo de ensino e aprendizagem.

Apesar da negação de tal comportamento, a experiência vivida pelos estagiários diante do professor colaborador acaba fazendo parte de seus repertórios mais gerais (VIGOTSKY, 2009). Ou seja, apesar de, naquele momento, tais práticas do professor da escola não serem consideradas úteis no ambiente da sala de aula pelos licenciandos, as mesmas podem ser levadas em consideração em momentos futuros, onde se remeteria a tais práticas de acordo com a necessidade imposta pelo entorno cultural do docente.

Assim, o Conhecimento Pedagógico de Conteúdo prévio que os estagiários já possuíam acerca do ensino da Física (aqui tratada, ainda que de forma geral, como um conteúdo a ser ensinado) se mantiveram após a observação das aulas do professor colaborador, sendo tal visão transportada para o ensino específico dos conceitos de astronomia, que seriam explorados pelo grupo de licenciandos em suas aulas futuras.

A seguir, focaremos em episódios de ensino que levam a outras fontes de perturbações, mais fortes nesse caso, que permearam o processo de estágio do Grupo II - a avaliação dos alunos e a indisciplina.

\subsection{O Caminho Criativo Gama}

Conforme exposto na análise do trajeto de estágio do Grupo I, as condutas caracterizadas como gama se revelam mais profundas do que as outras, sendo capazes de gerar conflitos e, portanto, alterações mais profundas nos esquemas de conhecimentos docentes.

Em nossa análise, os conflitos surgidos, juntamente com as necessidades criativas para a solução dos mesmos, acabam por levar o licenciando ao seu conjunto próprio de repertórios, que levariam à criação de novas intervenções. Tais criações seriam validadas ou não na prática docente no ambiente de sala de aula, incorporando-se ao novo sistema de conhecimentos do professor. 
A seguir, exporemos um conjunto de perturbações identificadas nos relatos dos estagiários do grupo I que apresentam características condizentes com a conduta gama: a avaliação dos alunos, a prática do professor colaborador e a indisciplina na prática de sala de aula.

\subsubsection{A Avaliação e Indisciplina dos Alunos}

Os licenciandos A, L e W, ao elaborarem seu projeto de estágio, apresentavam como objetivo, em sua dimensão pesquisa, um estudo dos diversos métodos de avaliação e suas consequências na aprendizagem dos alunos. Desse modo, uma prática recorrente do grupo era, ao término de cada aula, avaliar a apropriação do conteúdo abordado por parte dos discentes.

Tais métodos avaliativos, incentivados pela prática investigativa do estágio, apesar de terem apresentado objetivo inicial de verificar a aprendizagem dos estudantes, acabaram por se transformar em uma das mais fortes fontes de perturbações no trajeto do estágio dos licenciandos. Também em relação a este cenário, pode-se constatar que o quadro de indisciplina dos alunos das turmas onde o grupo lecionava contribuiu para reflexões posteriores dos futuros docentes. Os episódios apresentados a seguir, apesar de já apresentados no tópico 5.2.1 deste trabalho, serão novamente utilizados, porém, com enfoque destinado à perturbação surgida devido aos resultados da avaliação aplicada, conforme exposto a seguir.

(Sup3-11:17)

A: Parecia que a aula tinha sido legal, mas depois a gente viu que tinha uns poucos bons [resultados]... a maioria copiou, entregou em branco... eles não entenderam..não estavam nem aí....

O episódio anterior retrata a primeira intervenção do Grupo II em sala de aula. Nota-se que a prática dos estagiários, considerada a ideal por eles, não surtiu efeito prático na avaliação dos estudantes e em seu quadro de indisciplina. Tal situação conflituosa ocorrida devido a elementos do meio social aponta para o surgimento da necessidade (RIGON, 2009, VIGOTSKY, 2009) docente de repensar a própria prática para a próxima intervenção, apresentando como objetivo uma melhora na aprendizagem discente, conforme ilustrado a seguir. 
(Port)

A: As avaliações da primeira aula nos assustaram um pouco, nos fazendo pensar em porque eles [os alunos] não estavam aprendendo. A gente tinha que mudar nossa aula.

(Port)

L: A indisciplina atrapalha, também. Estamos tentando tornar as aulas mais interessantes, mas os alunos fazem muito barulho.

Os episódios acima demonstram a preocupação do grupo de licenciandos com a aprendizagem dos estudantes ("As avaliações da primeira aula nos assustaram um pouco... porque eles [os alunos] não estavam aprendendo. A gente tinha que mudar nossa aula”), caracterizando, a nosso ver, o direcionamento para a realização de uma atividade (RIGON, 2009, VIGOTSKY, 2009) criadora, utilizando-se o sentido de atividade atribuído pelos autores citados, onde a motivação e objetivo final das ações propostas pelos estagiários parecem convergir para o mesmo ponto: a melhora na aprendizagem dos alunos. Também é possível verificar que o quadro de indisciplina em sala de aula torna-se mais um fator perturbador ao caminho dos estagiários.

Neste ambiente, notamos que a criação elaborada pelo grupo II, conforme já citado no tópico anterior deste trabalho, tem sua origem remetida aos conhecimentos trabalhados na disciplina "Metodologia do Ensino de Física II".

(Port)

L :... conforme já tínhamos visto nas aulas [de Metodologia do Ensino de Física II], a participação dos alunos é fundamental... vamos utilizar três alunos para explicar as fases da Lua, chamando um novo trio para cada nova fase da Lua.

(Port)

A: Tentaremos deixar a aula mais dinâmica, usando alunos para representar os astros..na primeira aula, percebemos que os alunos conversam muito, então já pensamos em atividades de caráter mais lúdico.. para eles ficarem mais entretidos. 
(Aula)

A: A gente tentou usar a participação dos alunos...como [nome da professora de Metodologia do Ensino de Física II] já tinha dito. Achamos fundamental...

Os episódios anteriores corroboram com nossa visão de que os resultados não esperados na avaliação dos alunos e seu comportamento em sala de aula, geraram, em um ambiente de planejamento, a instalação de conflitos e, consequentes necessidades criativas por parte dos licenciandos, que recorreram a repertórios adquiridos em um dos contextos socioculturais (VIGOTSKY, 2001) onde encontravam-se inseridos - a disciplina de Metodologia de Ensino de Física II - para criar a nova intervenção. Tais características nos permitiram identificar a conduta gama (PIAGET, 1976) na elaboração desta intervenção.

A utilização de elementos da disciplina de Metodologia do Ensino de Física II cursada pelos futuros professores volta a ser identificada no trajeto do grupo II, agora na utilização de um novo método de avaliação, conforme ilustrado abaixo.

(Sup5-18:19)

W: A gente está pensando em fazer um júri aberto... primeiro a gente vai propor o problema aberto de que a Terra vai explodir e a gente precisa ir para outro planeta... que condições deveriam existir para a gente ir para lá?

O trecho acima retrata, portanto, que a metodologia empregada pelos estagiários nesta intervenção apresenta relação com conteúdos já trabalhados na disciplina citada, mais precisamente a utilização de problemas abertos em sala de aula como forma de propiciar discussões, debates e valorização de variáveis importantes à realização do problema.

Do ponto de vista do entorno cultural onde o estagiário está inserido, voltamos a salientar a importância do caráter investigativo do processo de estágio. Tal importância pode ser verificada pelo fato do conflito em tela ter surgido após a análise dos resultados avaliativos dos discentes, tema este escolhido pelo grupo de licenciandos em seu viés pesquisa. Podemos inferir que, em uma situação clássica de estágio, onde o licenciando apenas observa um professor mais experiente e realiza poucas intervenções, 
a situação conflitiva dificilmente seria percebida pelos futuros professores, não ocasionando alterações profundas em seu sistema de conhecimentos.

Em relação a tais alterações, podemos notar que os futuros docentes recorreram, explicitamente, a repertórios relacionados com estratégias pedagógicas adquiridas durante discussões ocorridas em suas aulas de Metodologia do Ensino de Física II para a abordagem do conteúdo relativo à Astronomia, podendo-se inferir acerca do aumento de repertório que essa disciplina propiciou ao grupo. A utilização destes elementos é proposta para um contexto específico das salas de aula onde realizavam o processo de estágio, nos levando a inferir acerca da elaboração, ainda que coletivamente, de um novo Conhecimento Pedagógico de Conteúdo (SHULMAN, 1987) por parte dos licenciandos.

Novamente, enfatizamos nesse ponto que, a análise do grupo II foi realizada de forma coletiva devido ao fato de seus integrantes, ao ministrarem todas as aulas do estágio, bem como a realização dos planejamentos e debates de forma conjunta, apresentavam-se como uma unidade única de análise no tocante às questões referentes a esta pesquisa, sendo que os estagiários que formavam tal grupo apresentavam desenvolvimentos similares relacionados aos processos criativos e elaborações dos respectivos PCK.

Em relação aos elementos do Conhecimento Pedagógico de Conteúdo elaborado, - aulas com participação dos alunos não garantem sua aprendizagem podemos analisá-lo mediante o desenvolvimento independente das dimensões do contexto, pedagógica e do conteúdo abordadas nas falas dos estagiários, caracterizando um PCK em patamar Integrativo (GESS-NEWSOME, 1999), onde tais conhecimentos se integraram para a elaboração de um novo conhecimento por parte do futuro professor. Salientamos, neste ponto, que o ambiente onde surgiu tal conhecimento tratava-se de momentos de planejamento dos licenciandos para criações de intervenções futuras com suas turmas. A seguir, procuramos expor um esquema que ilustra tal alteração. 


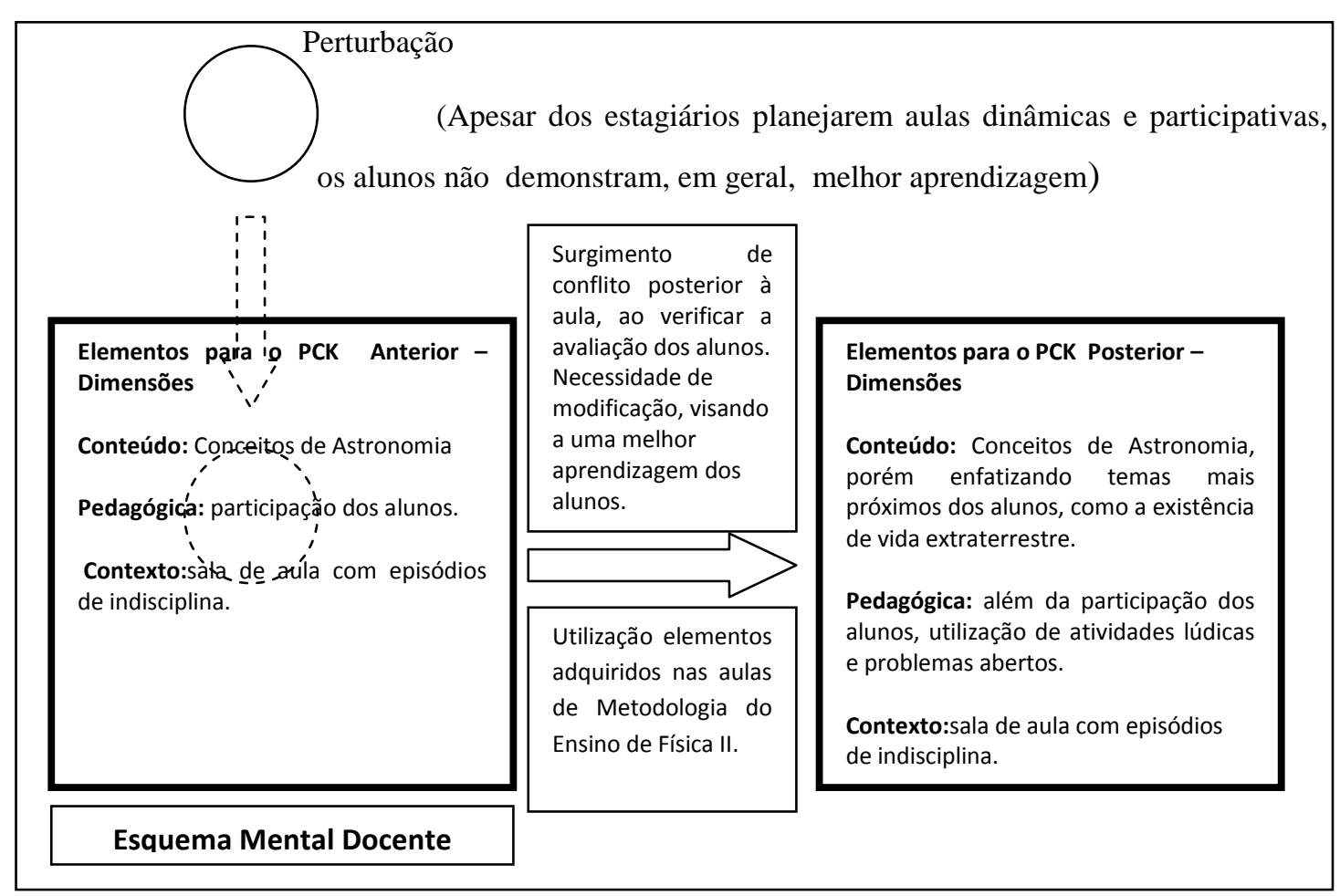

Fig.18 -Esquema de Caminho Criativo Gama do Grupo II

O esquema anterior busca ilustrar o fato da perturbação ser incorporada no sistema atual de conhecimentos docente, sendo esse ineficaz para a resolução das instabilidades surgidas. A modificação ocorrida, demonstrada pelo novo Conhecimento Pedagógico de Conteúdo surgido, buscou uma resposta ao fato das avaliações dos alunos apresentarem baixo rendimento, mesmo após a utilização de aulas mais dinâmicas e participativas.

A seguir, exporemos mais uma situação de conduta gama identificada na prática docente do Grupo II, deflagrada, agora, por um episódio de indisciplina em sala de aula.

\subsubsection{A Indisciplina na Sala de Aula}

Neste tópico, abordaremos a última intervenção realizada pelo grupo II em ambiente escolar, focando em um momento específico onde a indisciplina da turma, claramente, gerou perturbações nos esquemas de conhecimentos docentes.

$\mathrm{Na}$ aula ministrada pelos estagiários, conforme já explicitado anteriormente neste trabalho, os alunos deveriam responder a um problema aberto envolvendo a possibilidade de vida extraterrestre, conforme exposto a seguir. 
(Sup7-5:56)

A: ...A gente propôs o júri aberto... quais as características que precisava ter para se ter vida fora da Terra... primeiro a gente conversou com eles sobre a atividade... aí a gente propôs o problema, eles [os alunos] começaram a conversar... se era vida inteligente, se não era... a resposta deles foi bem objetiva... água, energia nuclear...

Durante a execução da atividade, os estagiários constataram, de acordo com o trecho a seguir, que nem todos os estudantes participavam.

(Sup7-5:56)

A: ... foi meio legal... porque metade da direita prestou atenção na gente, mas a metade da esquerda, nada... na outra turma, também... metade ótima... metade péssima...paciência... não dá para parar no meio, né?

Mesmo com uma parcela da turma não se envolvendo na atividade, a questão de sobrevivência docente (HUBERMAN, 1992) volta à tona durante a intervenção - a estagiária não cogita parar a atividade devido a não participação de metade da sala (“não dá para parar no meio, né?"), provavelmente temerosa em perder o controle da sala inteira. Apesar desta preocupação, o momento mais complexo de instabilidade dos estagiários ocorreria neste momento, conforme relatado a seguir.

(Sup7-5:56)

A: Demorou vinte minutos para eles ficarem quietos... aí a gente falou da gravação... que a gente ia gravar o rosto de cada um...

(Sup7-9:31)

L: Nossa...(expressão de susto) eu já tinha feito isso quando era aluno... tentar fazer movimento da sala para derrubar um professor... mas não achei que era assim... A sala inteira já estava gritando que não podia, que a gente não podia fazer isso... virou um tumulto... minha cabeça começou a explodir...

Nesta etapa, após os estagiários afirmarem que filmariam a opinião de cada aluno, instalou-se um tumulto generalizado na sala. Os estagiários, claramente assustados com aquela situação tentam, rapidamente, recuperar o controle da turma, conforme segue no episódio a seguir: 
(Sup7-9:59)

A: Aí eu falei (expressando um grito)...Tá bom, tá bom... Tá todo mundo com zero! Ah... eu sou muito boazinha, mas não deu... pelo menos eu consegui controlar a sala de novo.

(Sup7 - 10:55)

L: Aí eu também disse que eles iam ser a única sala que não ia fazer a atividade... eu lembro que quando meu professor fazia isso, dava certo... aí a aluna veio me perguntar: mas para quem mais você dá aula? Aí eu disse: dou aula para os dois primeiros anos, o segundo ano, o terceiro... inventei tudo, para fazer a maior pressão... mas foi um tumulto.

Os episódios anteriores demonstraram, claramente, uma situação de alta instabilidade sofrida pelos licenciandos durante o estágio. Conforme já ocorrido no grupo I, este tipo de situação caracterizou-se pela conduta gama (PIAGET, op.cit.) com geração de conflitos devido aos elementos sociais e culturais envolvidos naquele momento (CASTORINA, op.cit.) nos esquemas de conhecimentos dos futuros professores, os quais, segundo Huberman (1992), encontram-se na fase da sobrevivência docente, procurando manter, a todo custo, o controle da sala de aula, mantendo sua disciplina.

A necessidade do controle da sala nesta fase pré-profissional do futuro docente ainda nos é alicerçada por Beach \& Pearson (1998), onde as relações interpessoais com os alunos têm papel de destaque para o estagiário, sendo importante sua manutenção. Ainda para os autores, ao assumir a existência do conflito, os licenciandos buscam, em uma primeira instância, soluções de curto prazo, que debelem a causa da perturbação.

Dessa forma, do tumulto deflagrador do conflito devido a elementos cognitivos e sociais daquele momento emerge uma necessidade docente de conter tal situação, sendo que tal resposta deverá ocorrer na forma mais rápida e eficaz, procurando minimizar o descontrole instaurado na turma.

Tal resposta remeteu-se ao fato de que os estagiários sabiam que, naquele contexto específico, ocorriam reiteradas negociações entre o professor colaborador e os alunos com base em notas que estes últimos teriam para sua avaliação (“...o professor chantageava os alunos com nota", segundo o estagiário L, em sua entrevista). Apesar deste fato ter sido extremamente criticado pelos estagiários no início do processo, foi 
este o modelo encontrado pela licencianda A para conter o tumulto da turma ("Tá bom, tá bom... Tá todo mundo com zero... pelo menos eu consegui controlar a sala de novo").

Já o licenciado L optou por um modelo anteriormente utilizado por um exprofessor ("iam ser a única sala que não ia fazer a atividade") e que, segundo seu relato, "dava certo". Para manter o controle da sala através do modelo escolhido, o estagiário L fez uso de mentiras ("dou aula para os dois primeiros anos, o segundo ano, o terceiro... inventei tudo, para fazer a maior pressão”), pois seu principal objetivo, naquele momento, era a necessidade de manter a sala sob controle, fazendo a manutenção de sua "sobrevivência" (HUBERMAN, 1992) àquela situação docente encontrada.

A sequência de aulas ministradas pelo grupo II, descrita anteriormente, demonstrou, claramente, um embate direto dos estagiários com a questão disciplinar da sala de aula. Desta forma, a criação dos licenciandos visava a um combate desta situação, contribuindo para surgimento de alguns elementos de ensino, conforme exporemos a seguir.

(Sup3-17:43)

Contexto do relato: o estagiário procura validar uma estratégia para o tratamento de salas indisciplinadas.

W: Começa a entrada [dos alunos]... eles acalmam naturalmente... mas é só a gente dar risada que a gente perde o controle total da sala $\ldots$

$\mathrm{Na}$ mesma linha de pensamento, o estagiário L também procura encontrar formas de manter a sala sob controle:

(Sup7-26:36)

Contexto do relato: o estagiário faz uma avaliação geral do estágio, enfocando a questão disciplinar da sala de aula.

L: Para mim foi muito desgastante, porque além de não ter o apoio dos alunos, não tinha o apoio do professor... eles [os alunos] só faziam [alguma atividade] se valesse nota.

Os relatos anteriores evidenciam estratégias validadas pelos estagiários que poderiam se generalizar para classes indisciplinadas, em geral. Enquanto o estagiário W 
aponta o fato de não dar risada como fundamental para o controle da turma, o licenciando L enfatiza a necessidade dos alunos realizarem atividades valendo nota para participarem das mesmas. Este último fato nos pareceu validado para o grupo de estagiários, uma vez que os mesmos utilizaram este repertório para controlar o tumulto ocorrido com a turma durante a quarta aula do estágio, representado novamente abaixo.

(Sup7-9:59)

A: Aí eu falei (expressando um grito)...Tá bom, tá bom... Tá todo mundo com zero! Ah... não deu... pelo menos eu consegui controlar a sala de novo.

A utilização de nota como "moeda de troca" entre professor e aluno, tão criticada pelos licenciandos no início do estágio, acabou sendo utilizada como meio de controlar a disciplina da sala e foi novamente citado pela estagiária A, após o término do estágio.

(Sup7-27:10)

Contexto do relato: estagiária A relata como conseguiu fazer a sala produzir a avaliação final do estágio.

A: Eu entrei na sala e tive que dizer: pessoal, a gente resolveu que ia dar uma prova individual... mas a gente resolveu dar uma coisa em grupo [avaliação final do estágio]... só assim, mesmo... se eu não tivesse falado isso, acho que eles não iam fazer.

O trecho acima demonstra de forma mais evidente como o comportamento do professor colaborador, anteriormente criticado pelos licenciandos, torna-se um dos modelos utilizados por estes para conseguir a participação da turma, informando os alunos, de forma incisiva, que se não fizessem a atividade solicitada, fariam um prova individual.

Ainda no tocante à questão disciplinar, a estagiária A buscou sintetizar atitudes por parte do docente que contribuiriam para diminuir a indisciplina em salas de aula:

(Port)

Contexto do relato: a estagiária comenta sobre o aspecto disciplinar das salas onde estagiou.

A: Para contornar isso [a indisciplina] tentamos fazer perguntas a todo momento [para os alunos que conversavam]... conforme fomos 
aprendendo os nomes deles [dos alunos], pudemos perguntar para cada um sobre o assunto...Saber o nome dos alunos parece ser importante, mostra respeito por eles e eles (sic) percebem...acabam te respeitando mais.

Analogamente com os resultados obtidos com o grupo I, a estagiária, com o objetivo de combater possíveis conversas dos alunos durante a explicação do professor, elabora a estratégia com base em seus conhecimentos experienciais do estágio. Desta forma, o fato de fazer perguntas aos alunos que conversam dá resultados para retomar a atenção dos mesmos. Em um aprofundamento desta proposta, a estagiária constata que realizar tais perguntas, tratando o aluno pelo seu nome, traz um aparente aumento de respeito dele em relação ao docente, contribuindo para um maior controle disciplinar da turma ("acabam te respeitando mais").

Em suma, em relação à questão disciplinar, pode-se verificar a criação de algumas estratégias por parte dos estagiários, que de acordo com os relatos, parecem ter sido validadas em seus esquemas de conhecimentos docentes, sendo pertencentes, portanto, à dimensão contexto (GROSSMAN, 1990) de seus Conhecimentos Pedagógicos de Conteúdo.

Dessa forma, tais estratégias, que influenciaram na criação das intervenções dos estagiários durante sua prática, estarão disponíveis nos repertórios dos licenciandos para possíveis utilizações em situações futuras similares. A importância atribuída ao foco disciplinar pelos estagiários pode ser corroborada com o relato de A, exposto a seguir, quando questionada a respeito de uma nova aplicação sobre o conteúdo específico de astronomia.

(Sup7 - 15:30)

Pesq: Se você fosse tentar abordar este conteúdo novamente? Você mudaria algo?

A:... a escola (risos)...mas eu tentaria mudar meu comportamento... tentaria colocar mais ordem na sala logo no começo... [a astromomia] exige uma concentração grande dos alunos.

Ressalta-se, também, que o contexto de indisciplina, conforme relatado nos episódios anteriores, acabou gerando, simultaneamente, estratégias pedagógicas utilizadas na prática de sala de aula para o ensino deste tópico de Astronomia. Tal fato 
nos permite apontar para uma possível elaboração de um Conhecimento Pedagógico de Conteúdo (SHULMAN \& SHULMAN, 2004, p.e.) - É preciso estabelecer a forma e a natureza da participação dos alunos; a ordem é necessária para manter um ambiente de aprendizagem - haja vista a criação dos estagiários apresentar características que permitem serem caracterizadas nas dimensões de contexto, conteúdo e pedagógica como elaborado por Shulman (1987) em seu modelo inicial.

Neste ponto, inferimos que a origem de tal criação se deu na prática de sala de aula e mediante validações experienciais, o que corrobora, segundo Gess-Newsome (1999), com a criação de um PCK em um patamar Transformativo, tendo em vista o fato de não ocorrer a explicitação do desenvolvimento em separado das dimensões do Conhecimento Pedagógico de Conteúdo. O esquema a seguir, busca uma representação desta última situação vivida pelos estagiários do grupo II.

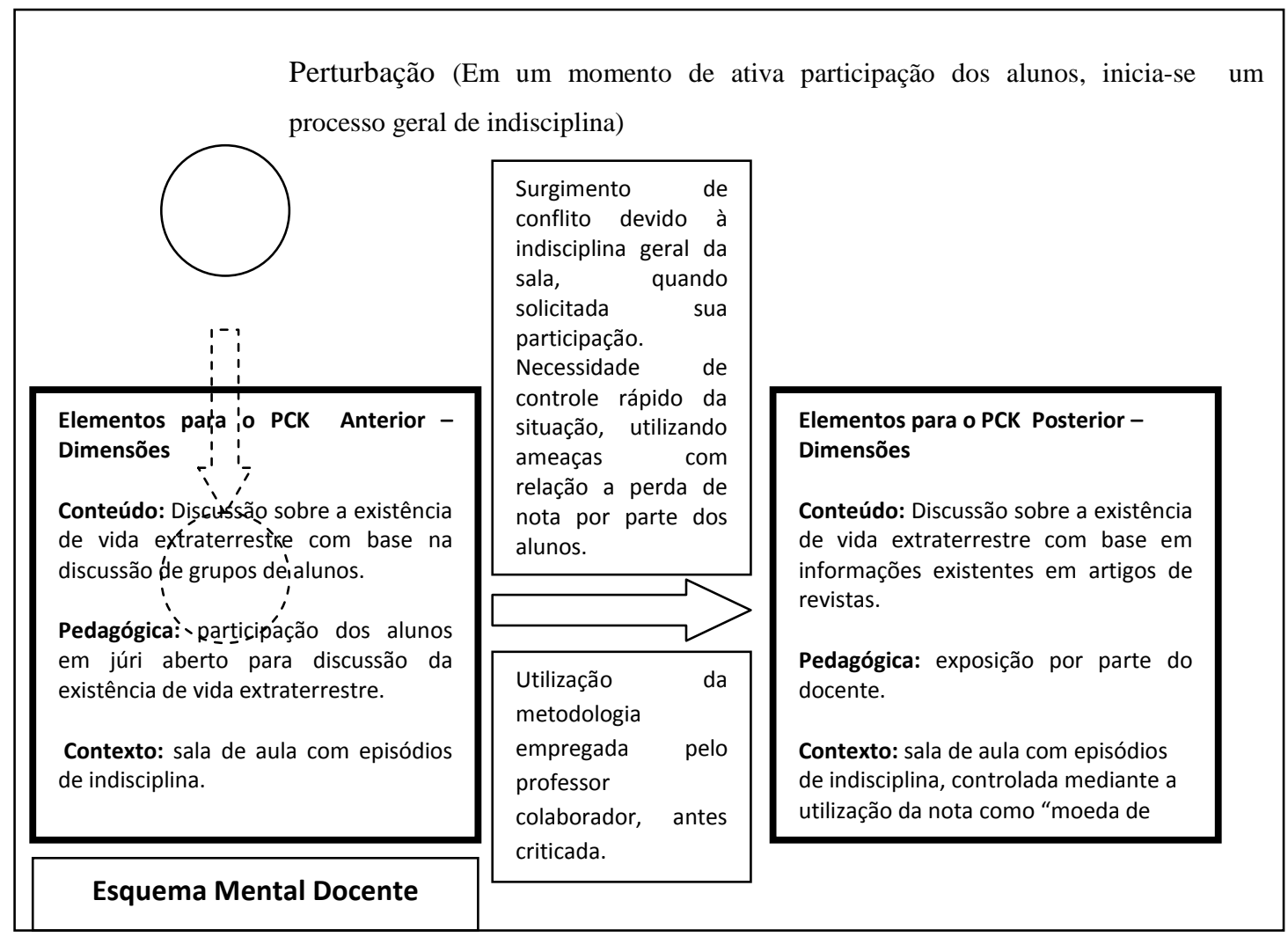

Fig.19-Esquema de Caminho Criativo Gama do Grupo II

O esquema anterior ilustra o fato de que perturbação advinda do quadro geral de indisciplina, instaurado na sala de aula, é incorporada pelo sistema de conhecimentos atual do futuro professor, não sendo esse, eficaz na resposta a tal instabilidade. Novamente, verificamos que o entorno cultural onde ocorreu tal situação de conflito 
relaciona-se com a solução encontrada, haja vista que, visando a sua sobrevivência na sala de aula (HUBERMAN, 1992), o licenciando busca soluções de rápida resposta (BEACH \& PEARSON, 1998), utilizando de exemplos advindos de seu repertório anterior que se demonstraram eficazes na resolução de situações ocorridas em contextos similares.

A seguir, abordaremos os principais elementos expostos na análise dos dois grupos de estagiários, procurando sintetizar os principais elementos inerentes ao processo criativo e suas influências na dinâmica de elaboração de novos Conhecimentos Pedagógicos de Conteúdo.

\section{Os Processos Criativos e os Conhecimentos Pedagógicos de Conteúdo: síntese dos resultados e articulações finais}

O presente capítulo possuía como objetivo apresentar os resultados do trabalho de campo efetuado nesta pesquisas, bem como suas interpretações, calcadas nos referenciais teóricos expostos nos capítulos II e III.

De maneira geral, buscamos a análise de dois grupos de estagiários, denominados grupos I e II, que assistiam, regularmente, às aulas da disciplina Metodologia do Ensino de Física II, bem como participavam de suas respectivas reuniões de supervisão, que apresentavam frequência semanal. Os resultados analisados foram retirados de episódios ocorridos nas reuniões de supervisão e portfólios dos futuros professores, além de entrevistas finais realizadas ao término da disciplina, conforme sintetizado abaixo.

\section{Grupo I: síntese}

Em um primeiro momento, em relação ao grupo I, os integrantes, denominados neste trabalho, por R e C, não apresentavam, até o início do estágio em tela, relevante experiência em sala de aula, acumulando algumas aulas particulares ou estágios obrigatórios de observação realizados em outras disciplinas oferecidas pela Faculdade de Educação e pelo Instituto de Física da Universidade de São Paulo (USP).

O processo de estágio destes licenciandos iniciou em uma escola pública estadual do município de São Paulo, considerada por ambos como sendo uma 
instituição tradicional e organizada. Neste ambiente, a professora colaboradora, bem como à equipe gestora (coordenação e direção) ofereceram todo apoio aos estagiários, demonstrando interesse no projeto realizado e suas possíveis colaborações para o processo de aprendizagem de seus alunos.

O projeto de estágio desenvolvido por R e C tratava-se de uma sequência de quatro aulas que abordavam a conservação da quantidade de movimento, tendo sido criado, inicialmente, com o intuito de ser um mini-curso apresentado na disciplina de Metodologia do Ensino de Física I, realizada por ambos em semestre anterior à realização do estágio. Tal sequência culminaria, em sua última aula, com a construção e lançamento de um foguete confeccionado em garrafa pet e com propulsão de água pressurizada.

Para adequar-se à proposta de estágio investigativo (ABIB, 2010) proposta pela professora da disciplina Metodologia de Ensino de Física II, o grupo inseriu um questionamento acerca da motivação que um conjunto de atividades experimentais, que culminariam com a construção e lançamento de um foguete artesanal traria aos estudantes do ensino médio.

Nesse momento, ao apresentarem o citado projeto à professora colaboradora da escola, a mesma solicitou que os licenciandos retirassem qualquer abordagem matemática que viesse a estar inserida nas aulas, alegando que as turmas onde o processo de estágio se realizaria não apresentavam uma base sólida em cálculos algébricos, sendo que tal fato poderia causar a desmotivação dos mesmos.

A solução encontrada pelo grupo para a resolução desta solicitação foi, simplesmente, efetuar a retirada das intervenções matemáticas, não realizando qualquer outro tipo de adaptação ao planejamento, que, como já observado, foi criado inicialmente para um ambiente de mini-curso, e não de uma sala de aula regular do ensino médio.

Com o início das atividades dos estagiários em sala de aula, constatou-se, desde a realização da primeira intervenção, o surgimento de imprevistos durante a prática dos licenciandos, a maior parte oriunda de fragilidades na elaboração do planejamento que culminaram, inclusive, com estudantes esperando pelo término precoce da aula, porque o experimento proposto foi realizado de forma muito rápida. 
Tais fragilidades acabaram, inclusive, por desencadear episódios de conflitos de natureza sociocognitiva (CASTORINA, 2008), produzidos por elementos sociais e culturais específicos da situação onde os licenciandos se encontravam, tais como a indisciplina dos alunos e a infraestrutura da escola. Tais instabilidades foram acompanhadas de necessidades criativas, ora relacionadas com a própria sobrevivência docente (HUBERMAN, 1992), ora relacionadas com preocupações sobre a aprendizagem discente.

Em relação aos Conhecimentos Pedagógicos de Conteúdo elaborados, observamos que, em relação aos Caminho Criativo Lacunar e Beta, não constatou-se alterações significativas que pudessem gerar novos PCK, prevalecendo, de maneira geral, as dimensões do contexto, conteúdo e pedagógicas já existentes antes dos episódios de ensino.

Já em relação aos Caminhos Criativos Gama identificados, foi possível verificar a instalação de novos PCK, com alterações nas dimensões pedagógica e do conteúdo disparadas pelo contex to sociocultural onde encontrava-se inserido os licenciandos.

\section{Grupo II: síntese}

Já em relação ao grupo de estagiários II, os integrantes, denominados neste trabalho como $\mathrm{A}, \mathrm{L}$ e $\mathrm{W}$ também não apresentavam experiência na regência de salas de aula, conhecendo este ambiente através dos estágios de observação realizados pela Faculdade de Educação da Universidade de São Paulo.

Este grupo optou por desenvolver com os alunos do $1^{\circ}$ ano do ensino médio, intervenções que abordassem os conceitos básicos de astronomia em quatro aulas, enfatizando as medidas em astronomia, as fases da Lua, as características dos planetas e a questão da vida extraterrestre. A ideia de trabalhar este conteúdo parece ter se originado da influência que um professor da disciplina "Conceitos de Astronomia", oferecida aos licenciandos em Física, teve sobre o grupo, afirmando que o tema era uma excelente forma de iniciar o tratamento da Física no nível escolar.

No tocante à dimensão de pesquisa atribuída ao estágio investigativo, este grupo de estagiários optou por tratar a questão dos métodos de avaliação, verificando em qual deles os estudantes conseguiam expor suas ideias de forma mais clara. Para tanto, os 
licenciandos utilizaram diferentes formas de intervenções, tais como aula expositiva, demonstrações, jogos e júris simulados.

Diferentemente do $1^{\circ}$ grupo, os estagiários desde o início do processo, não concordavam com a prática de sala de aula do professor colaborador, realizando reiteradas críticas em relação ao seu modelo de controle disciplinar da sala, baseado na negociação de notas com os estudantes, bem como na forma de expor os conteúdos apenas oralmente, pouco utilizando a lousa ou qualquer outra estratégia que não remetesse a um ensino puramente tradicional.

Nesse contexto, os licenciandos, em uma situação de provável conduta alfa (PIAGET, 1976) em relação às práticas do docente colaborador, as negaram, não as julgando relevantes de pertencer a seus sistemas de conhecimentos docentes. Dessa forma, procuraram, em um primeiro momento, planejar aulas fundamentadas em uma maior participação dos alunos, tema este originado do repertório (VIGOTSKY, 2009 e PIAGET, 1972) do grupo, obtido nas aulas de Metodologia do Ensino de Física II. Para frustração do grupo, a estratégia escolhida esbarrou na indisciplina das turmas, refletindo em avaliações com resultados próximos aos obtidos pelo professor colaborador.

Em um novo ciclo de perturbações, conflitos e necessidades, o grupo altera novamente a estratégia, buscando, desta vez, a participação dos alunos indisciplinados na frente da sala, auxiliando os estagiários na realização de uma demonstração. Ao aplicarem esta intervenção na $1^{\mathrm{a}}$ turma, os futuros professores constataram que a decisão não parecia ter sido uma boa ideia, uma vez que os alunos não se prontificavam a participar, atrasando, de sobremaneira, o andamento da aula. Tal situação de instabilidade em sala de aula não conseguiu ser resolvida pelos licenciandos durante a prática, sendo que a estratégia só foi alterada (eliminando-se a ampla participação discente) quando da realização da mesma aula, porém em outra turma.

$\mathrm{Na}$ sequência do estágio, o grupo II optou pela realização de uma atividade lúdica, envolvendo um jogo de cartas que continham as características dos planetas e estrela do sistema solar. Esta intervenção apresentou um aparente sucesso entre os alunos, causando a participação das turmas onde a mesma foi aplicada.

A quarta aula do grupo II foi palco da mais complexa situação de instabilidade sofrida pelos estagiários durante sua prática. Ao iniciarem uma atividade de júri 
simulado sobre a possibilidade de vida extraterrestre, os licenciandos informam que filmariam os alunos emitindo suas opiniões sobre a questão. Naquele momento, a turma, como um todo, iniciou um tumulto contra aquela atitude.

Os estagiários, expostos à situação de conflito (PIAGET, 2002) pelo contexto cultural onde estão inseridos (CASTORINA, 2008) sentem a necessidade primeira de sobreviver àquele momento (HUBERMAN, 1992), buscando um rápido controle da situação. Segundo os relatos do estagiários, tal resposta rápida (BEACH \& PEARSON, 1998), assim como ocorrido no grupo I, baseou-se em exemplos anteriores que os licenciandos consideravam já prontos e que, em suas aplicações anteriores, revelaram-se eficazes na resolução das instabilidades surgidas.

No caso em particular, os futuros docentes utilizaram o modelo já usado pelo professor colaborador (criticado, inicialmente, pelos mesmos estagiários) com ameaças aos alunos através de suas notas ("Tá todo mundo com zero!) ou através de posicionamentos tomados por ex-professores em situações de conflito similares ("Se não ficarem quietos, vocês vão ser a única sala que não vai fazer a atividade!’”.

No tocante aos Conhecimentos Pedagógicos de Conteúdo, analogamente ao ocorrido com o Grupo I, os Caminhos Criativos Alfa identificados no Grupo II não foram capazes de gerar alterações significativas que pudessem corroborar com a criação de novos PCK. Entretanto, os Caminhos Criativos Gama observados, pareceram trazer profundas alterações aos esquemas mentais dos licenciandos, gerando mudanças nas dimensões de conteúdo e pedagógicas, estas disparadas pelos elementos socioculturais do contexto onde os licenciandos efetuavam o processo de estágio.

\section{Articulações Finais}

Os imprevistos surgidos na prática docente, de maneira geral, provocavam instabilidades nos estagiários. Tais situações, de acordo com nossa proposta de categorização, poderiam ser classificadas de acordo com a psicologia piagetiana, onde tais momentos instáveis poderiam enquadrar-se em lacunas ou conflitos, sendo estes últimos caracterizados pela forma com que o indivíduo busca sua solução- as condutas alfa, beta ou gama.

Os licenciandos analisados, na tentativa de resolver tais situações, podiam simplesmente não conseguir resolvê-las, "ignorá-las conscientemente (MACEDO, 
2009)", incorporá-la a um conjunto de esquemas mentais já existentes, ou, em uma situação de alteração conceitual mais profunda, entrar em estado de conflito (PIAGET, 2002 e CASTORINA, 2008), sentindo a necessidade legítima (RIGON, 2009) de solucionar a instabilidade, seja promovendo uma maior aprendizagem discente, ou "sobrevivendo ao ambiente da sala de aula (HUBERMAN, 1992)", procurando evitar que um quadro de indisciplina se instalasse.

Este último caso, particularmente, fez com que os estagiários analisados criassem, no ambiente sociocultural do estágio, intervenções baseadas em exemplos pedagógicos já prontos e que se apresentavam eficazes na resolução de instabilidades surgidas naquele momento. Desta forma, constatamos licenciandos remetendo-se a formas de agir de seus professores de ensino básico, como escrever a matéria na lousa ou, mesmo, utilizar-se de modelos anteriormente criticados, mas que pareciam resolver as instabilidades surgidas naquele momento. De qualquer forma, tais criações com ênfase reprodutiva corroboraram com os referenciais vigotskianos (2009) e piagetianos (1972), que enfatizavam a necessidade do indivíduo apresentar amplo repertório e experiência vivida para criar.

Já no tocante ao planejamento das atividades pedagógicas, salientamos que esta fase não pode ser inteiramente acompanhada nesta pesquisa, haja vista que os grupos de licenciandos observados já apresentaram os projetos confeccionados, quando do início da tomada de dados. Entretanto, ao questionarmos os estagiários sobre a dinâmica da criação das atividades, os mesmos alegaram que a ideia teria se originado de experiências vividas pelos integrantes do grupo. A origem citada corrobora, novamente, com a importância dada aos repertórios de vida e experiências já citadas por Vigotsky (op. cit.) e Piaget (op. cit).

O surgimento de uma necessidade legítima docente, que buscasse o objetivo de uma melhor aprendizagem dos alunos, poderia culminar em uma atividade (RIGON, 2009; VIGOTSKY, 2009) criadora, podendo tal fato ser verificado quando do término do estágio, ao questionarmos os estagiários acerca de modificações que seriam efetuadas na sequência criada. Os relatos, baseados nos imprevistos surgidos, trazem a elaboração de novas intervenções futuras, por parte dos estagiários, sendo que nestes momentos, constataram-se episódios de reflexão dos licenciandos, citando, por exemplo, discussões que não foram bem conduzidas, experimentos que poderiam 
apresentar erro conceitual e necessitavam de alterações ou estratégias que combateriam a indisciplina em sala de aula.

Os momentos de criação citados anteriormente acabaram por se relacionar com a elaboração de novos conhecimentos pedagógicos de conteúdo, uma vez que o PCK resulta deste processo criativo, seja em relação a um conteúdo mais geral (como o ensino de Física) ou um viés mais específico (como o ensino de conceitos astronômicos ou quantidade de movimento, por exemplo). Conforme expomos no tópico anterior, o objetivo principal deste trabalho concentrou-se no estudo da dinâmica dos processos criativos, sendo os Conhecimentos Pedagógicos de Conteúdo, o contexto onde estes processos iriam se "cristalizar" (VIGOTSKY, 2009). Desta forma, na intenção de se interagir de maneira mais exploratória com os episódios de criação, acabamos por trazer elementos indicativos para uma caracterização dos conhecimentos elaborados em suas dimensões de conteúdo, pedagógica e do contexto.

Dessa forma, conseguimos localizar episódios de interesse acadêmico que traziam indícios de novos elementos docentes surgidos durante o processo de estágio, nos auxiliando, ainda que preliminarmente, na identificação de alterações nas dimensões conteúdo, contexto ou pedagógica inerentes ao PCK.

Tais alterações também nos permitiram inferir acerca dos modelos transformativo e integrativo atribuídos ao conhecimento pedagógico de conteúdo (GESS-NEWSOME, 1999 e KIND, 2009). Portanto, no caso específico da análise realizada neste trabalho, constatamos situações em que os estagiários dos grupos observados apresentaram elementos que apontavam para a elaboração de conhecimentos pedagógicos de conteúdo com características transformativas, todas elas ocorridas durante a ocorrência de imprevistos em sala de aula.

Neste momento, as criações analisadas dos licenciandos, nestas situações, apresentavam características de se reportarem a repertórios envolvendo práticas docentes já presenciadas, normalmente atreladas a ex-professores da educação básica, necessitando de respostas rápidas e eficientes para transpor as situações de perturbação surgidas no ambiente da sala de aula.

Esta forma de criação, altamente influenciada pelo contexto social e cultural (VIGOTSKY, 2001) dos futuros professores em sua formação inicial, baseia-se na necessidade da sobrevivência docente já tratada por Huberman (1992), onde o 
licenciando buscará tais tipos de elementos em seu repertório ou experiências vividas com o intuito de bloquear, da forma mais rápida e eficiente possível, a possibilidade de descontrole da turma. A utilização de respostas de curto prazo por estagiários no início de suas atividades docentes também nos é alicerçada por Beach \& Pearson (1998).

No tocante ao caso dos elementos do cotidiano docente que poderiam apontar para possíveis Conhecimentos Pedagógicos de Conteúdo de natureza integrativa, salientamos que os indícios de tais elementos se tornaram mais visíveis nas situações de planejamento de atividades futuras, em que solicitávamos ao estagiário, durante as reuniões de supervisão, que refletisse acerca de uma nova utilização do projeto de estágio, acenando para possíveis alterações que seriam realizadas.

Diante deste quadro e com base nos resultados encontrados neste trabalho, elaboramos as tabelas a seguir, que buscam, a título de síntese, expor os elementos, até então expostos, considerados relevantes para a criação docente, bem como relacioná-los com as perturbações que os originaram e os novos Conhecimentos Pedagógicos de Conteúdo elaborados ${ }^{26}$.

\footnotetext{
${ }^{26}$ Lembrando que as perturbações lacunares, bem como as condutas alfa e beta não demonstraram alterações relevantes na essência do PCK dos estagiários, permanecendo, de modo geral, o Conhecimento Pedagógico de Conteúdo anterior.
} 
GRUPO I - ESTAGIÁRIOS R e C

\begin{tabular}{|c|c|c|c|c|c|c|}
\hline Perturbações & $\begin{array}{c}\text { Tipo de } \\
\text { Perturbação } \\
\text { ou conduta }\end{array}$ & $\begin{array}{l}\text { Contexto da } \\
\text { Ocorrência }\end{array}$ & $\begin{array}{c}\text { Necessidade } \\
\text { Criativa }\end{array}$ & $\begin{array}{l}\text { Natureza da } \\
\text { Perturbação }\end{array}$ & $\begin{array}{l}\text { Principais } \\
\text { Repertórios } \\
\text { Recorridos }\end{array}$ & \begin{tabular}{|c|} 
Novos \\
Conhecimentos \\
Pedagógicos de \\
Conteúdo (PCK) \\
e sua natureza \\
\end{tabular} \\
\hline $\begin{array}{l}\text { Indisciplina } \\
\text { devido à } \\
\text { utilização de } \\
\text { matemática }\end{array}$ & Gama & Prática de aula & $\begin{array}{c}\text { Sobrevivência } \\
\text { Docente }\end{array}$ & Conflito & $\begin{array}{l}\text { Modelo de } \\
\text { ex-professor }\end{array}$ & 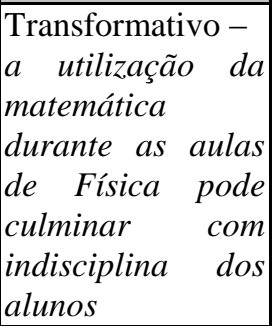 \\
\hline $\begin{array}{l}\text { Aprendendo } \\
\text { com o que } \\
\text { ocorreu }\end{array}$ & Gama & Planejamento & $\begin{array}{l}\text { Aprendizagem } \\
\text { Discente }\end{array}$ & Conflito & $\begin{array}{c}\text { Cursos de } \\
\text { Graduação e } \\
\text { lacuna } \\
\text { ocorrida em } \\
\text { aula anterior }\end{array}$ & \begin{tabular}{|lrl} 
Integrativo - \\
o rigor científico \\
nas \\
demonstrações \\
experimentais \\
realizadas r em \\
sala de raula \\
colaboram & com & a \\
melhor & & \\
aprendizagem & \\
discente & \\
\end{tabular} \\
\hline $\begin{array}{l}\text { Limitações } \\
\text { Impostas } \\
\text { pelo professor } \\
\text { colaborador } \\
\text { (Ausência da } \\
\text { Matemática) }\end{array}$ & Beta & Planejamento & - & - & - & - \\
\hline $\begin{array}{l}\text { Imprevistos com } \\
\text { Recursos } \\
\text { Didáticos }\end{array}$ & Gama & Prática de aula & $\begin{array}{l}\text { Sobrevivência } \\
\text { Docente }\end{array}$ & Conflito & $\begin{array}{l}\text { Modelo de } \\
\text { ex-professor }\end{array}$ & \begin{tabular}{|lr}
\multicolumn{3}{|l}{ Transformativo- } \\
expor a & matéria \\
na lousa & parece \\
diminuir r & a \\
indisciplina & na \\
sala de aula
\end{tabular} \\
\hline \begin{tabular}{|l|} 
Organização \\
Tempo Didático
\end{tabular} & Lacuna & Prática de aula & $\begin{array}{l}\text { Sobrevivência } \\
\text { Docente }\end{array}$ & Lacuna & - & \\
\hline
\end{tabular}

Tabela 6-Processo Criativo do Grupo I 


\begin{tabular}{|c|c|c|c|c|c|c|}
\hline \multicolumn{7}{|c|}{ GRUPO II - ESTAGIÁRIOS A, L e W } \\
\hline Perturbações & $\begin{array}{c}\text { Tipo de } \\
\text { Perturbação }\end{array}$ & $\begin{array}{l}\text { Contexto da } \\
\text { Ocorrência }\end{array}$ & $\begin{array}{l}\text { Necessidade } \\
\text { Criativa }\end{array}$ & \begin{tabular}{|l|} 
Natureza da \\
Perturbação
\end{tabular} & \begin{tabular}{|c|} 
Principais \\
Repertórios \\
Recorridos
\end{tabular} & \begin{tabular}{|c|} 
Novos \\
Conhecimentos \\
Pedagógicos de \\
Conteúdo (PCK) \\
e sua natureza \\
\end{tabular} \\
\hline $\begin{array}{l}\text { Participação } \\
\text { dos Alunos }\end{array}$ & Alfa & Prática de aula & - & - & - & - \\
\hline $\begin{array}{l}\text { Avaliação dos } \\
\text { Alunos }\end{array}$ & Gama & Planejamento & $\begin{array}{l}\text { Aprendizagem } \\
\text { Discente }\end{array}$ & Conflito & $\begin{array}{c}\text { Aulas de } \\
\text { Metodologia } \\
\text { de Ensino de } \\
\text { Física II }\end{array}$ & $\begin{array}{|lc|}\text { Integrativo- } & \\
\text { aulas } & \text { com } \\
\text { participação } & \text { dos } \\
\text { alunos } & \text { nao } \\
\text { garantem } & \text { sua } \\
\text { aprendizagem } & \\
\end{array}$ \\
\hline $\begin{array}{l}\text { A Prática do } \\
\text { Professor } \\
\text { Colaborador }\end{array}$ & Alfa & Planejamento & - & - & - & - \\
\hline $\begin{array}{l}\text { Indisciplina na } \\
\text { Sala de Aula }\end{array}$ & Gama & Prática de aula & $\begin{array}{l}\text { Sobrevivência } \\
\text { Docente }\end{array}$ & Conflito & $\begin{array}{c}\text { ex-professor } \\
\text { e } \\
\text { metodologia } \\
\text { do professor } \\
\text { colaborador, } \\
\text { até então, } \\
\text { descartada. }\end{array}$ & 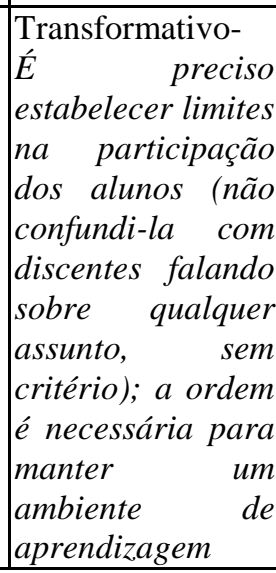 \\
\hline
\end{tabular}

Tabela 7 - Processo Criativo do Grupo II

As tabelas expostas anteriormente, nos trazem, portanto, importantes contribuições para uma visão mais geral e conclusiva sobre a dinâmica do processo criativo.

Uma análise dos elementos expostos nos permite verificar que o processo criativo é desencadeado por uma perturbação inicial, que pode ser da forma lacunar ou conflituosa, sendo estes últimos promovedores de condutas alfa, beta ou gama, de acordo com a profundidade com que esta atinge o sistema de conhecimentos docentes e os repertórios (ou ausência deles) utilizados para o enfrentamento da mesma.

Dessa forma, a situação de instabilidade, ao ser "ignorada conscientemente" (MACEDO, 2009), incorporada em um sistema já existente (conduta beta), ou ignorada pela ausência de repertórios para sua resolução (lacuna), geraram adaptações criativas 
por parte do professor em uma região do espectro criativo mais próxima do patamar reprodutor (VIGOTSKY, 2009).

Entretanto, algumas perturbações podem gerar condutas gama (PIAGET, 1976), em que o sistema de conhecimentos docente é desestabilizado de forma profunda, exigindo uma reorganização dos esquemas até então organizados devido aos conflitos de natureza sociocognitiva (CASTORINA, 2008) instalados. A conduta gama, portanto, implica na existência de uma necessidade criativa (RIGON, 2009) legítima por parte do futuro professor, que recorrerá a seus repertórios particulares (PIAGET, 1972 e VIGOTSKY, 2009) para o enfrentamento da situação de instabilidade.

Em suma, os resultados analisados neste trabalho apontaram para duas necessidades legítimas latentes dos futuros professores: a sobrevivência docente (HUBERMAN, 1992) e a aprendizagem discente. Os relatos dos estagiários permitiram localizar a questão de sobrevivência em momentos mais relacionados com a prática de sala de aula, enquanto que a preocupação com a aprendizagem discente centrou-se nos momentos de planejamento de intervenções didáticas futuras pelos licenciandos. Tal fato nos parece ser justificado pela necessidade da rápida resolução das instabilidades surgidas no ambiente escolar, não permitindo intervalos de tempo com duração que propiciariam uma reflexão mais profunda sobre os episódios de ensino.

Analogamente, esses mesmos resultados também acabaram por identificar a elaboração de Conhecimentos Pedagógicos de Conteúdo em um patamar Integrativo (GESS-NEWSOME, 1999) para aquelas criações geradas no ambiente de planejamento citado anteriormente, onde o estagiário nos parece apresentar um maior conforto para refletir sobre os problemas oriundos de suas intervenções em sala de aula e buscar auxílio em repertórios ligados ao seu próprio curso de graduação, como as disciplinas referentes ao estágio.

Já em relação às elaborações ocorridas no ambiente de sala de aula, verificamos, através das análises realizadas, que os Conhecimentos Pedagógicos de Conteúdo gerados apresentavam-se em um patamar Transformativo (GESS-NEWSOME, op.cit.), relacionando-se com a busca de repertórios, por parte dos estagiários, ligados a modelos de eficácia comprovada e de rápida aplicação (BEACH \& PEARSON, 1998) que remetiam a ex-professores de sua educação básica. 
Alguns relatos exibidos nos episódios de interesse acadêmico também apontam para o fato das criações dos licenciandos advindas de Caminhos Criativos Gama sofrerem um processo de validação no ambiente de sala de aula. A partir deste ponto, nota-se a composição de um novo repertório de criação do futuro professor, pertencendo a um novo sistema de conhecimentos docentes mais completo em relação ao anterior, e que, portanto, poderia ser acessado pelo estagiário em situações de criação futuras.

No caso da não validação destas novas intervenções, o processo retorna para a busca de novos repertórios que possam enfrentar por completo a instabilidade surgida e, dessa forma, completar o ciclo criativo docente, conforme buscamos ilustrar no esquema a seguir.

\section{CICLO CRIATIVO DOCENTE - ESQUEMA GERAL}

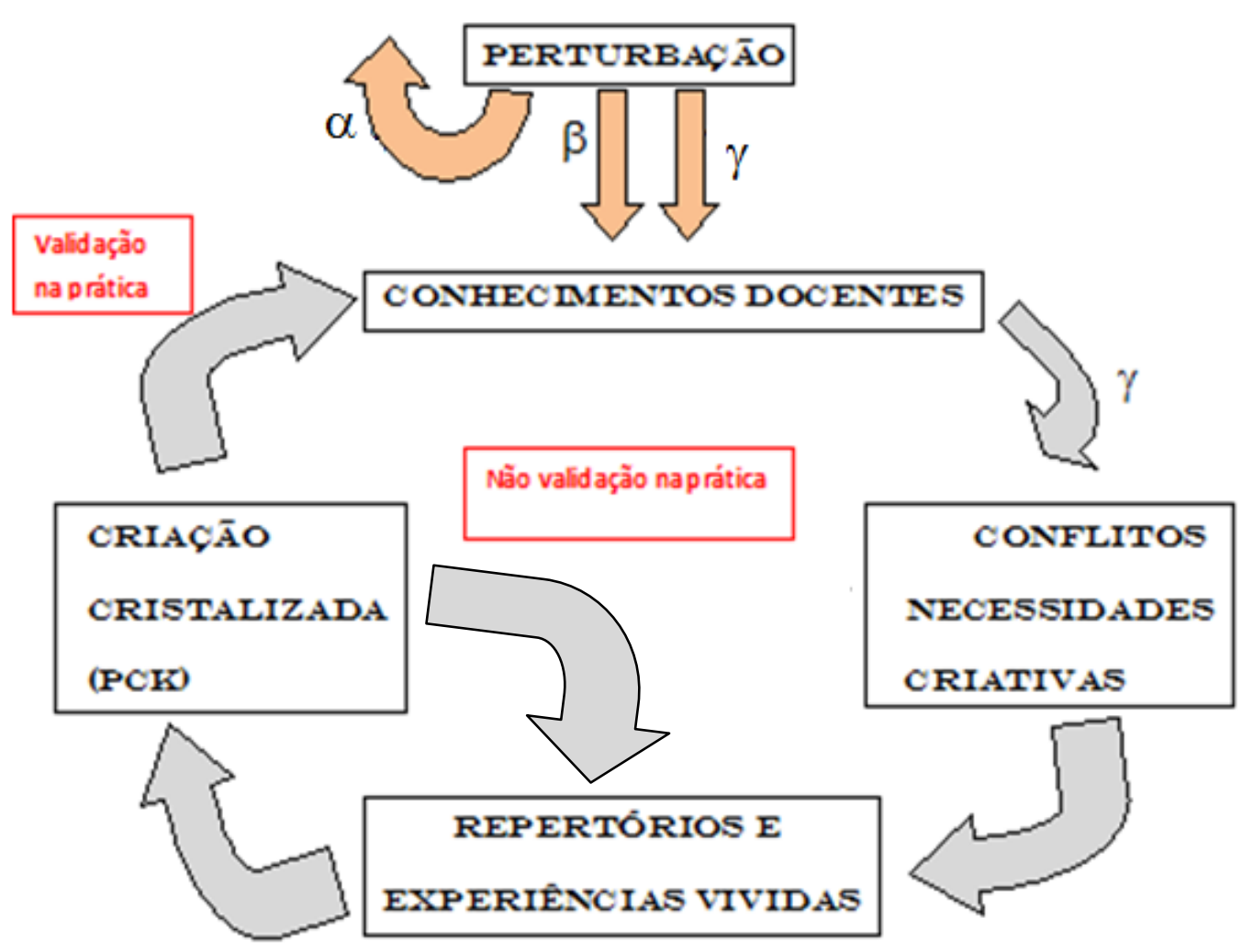

Fig.20 - Esquema Geral do Ciclo Criativo Docente 
Ressaltamos que tal ciclo, inspirado no ciclo da imaginação cristalizada (VIGOTSKY, 2009), apresenta um caráter didático, visando a uma melhor interpretação e visualização dos processos cognitivo-sociais envolvidos na criação de algo novo.

Dessa forma, note-se que os repertórios e experiências docentes vividas, apesar de fazerem parte dos conhecimentos docentes, encontram-se representados separadamente, buscando ilustrar a sua busca por parte do professor, quando os esquemas de conhecimentos atuais não satisfazem a perturbação surgida.

De um ponto de vista mais geral, podemos generalizar o esquema anterior para uma tentativa de compreendermos o ciclo de aprendizagem da docência, relacionando este processo à criatividade docente, conforme ilustra o esquema a seguir. 


\section{Problemas de Ensino}

(Perturbações advindas do cotidiano docente)

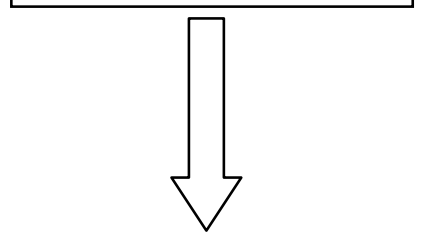

\begin{tabular}{|l|l|}
\hline \multicolumn{3}{l}{ Hipóteses Docentes } \\
(As Perturbações, de acordo \\
com sua natureza, podem ser \\
negadas, inseridas ou \\
colocadas em confronto com \\
as hipóteses existentes no \\
sistema de conhecimentos \\
docentes & do professor. \\
Também é & possível que os \\
esquemas & mentais do \\
professor não possuam \\
elementos para solucionar tal \\
instabilidade).
\end{tabular}

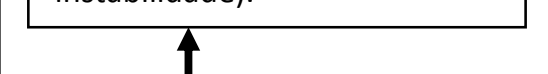

Se a perturbação confrontar as hipóteses já existentes...

\section{Repertórios Docentes}

(O professor recorrerá a elementos, relacionados diretamente ou não com o ensino e a aprendizagem, na busca de solucionar a instabilidade surgida).

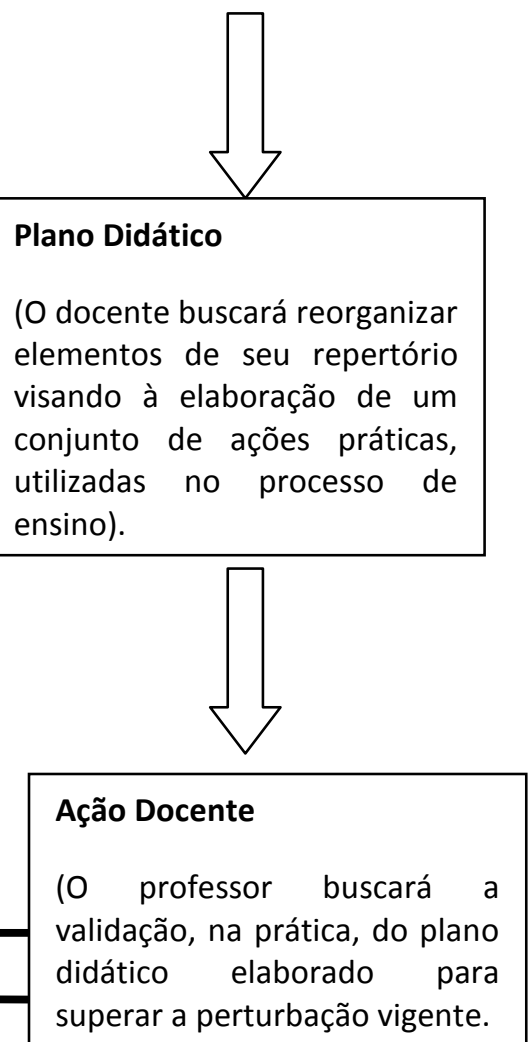

Fig.21 - Ciclo da aprendizagem da docência relativo à criatividade docente.

No esquema anterior, os problemas de ensino surgidos no ambiente cultural onde se encontra inserida a docência podem ser classificados de acordo com sua interação com o conjunto de hipóteses (esquemas docentes) do professor. Dessa forma, 
a perturbação poderá não encontrar elementos suficientes nos esquemas cognitivos docentes para sua superação (Caminho Criativo Lacunar), ser negada (Caminho Criativo Alfa), ser explicada pelo conjunto de hipóteses docentes atuais (Caminho Criativo Beta) ou, finalmente, necessitar de reformulações no conjunto de hipóteses iniciais devido à existência de conflito entre essas e a nova instabilidade.

No caso da conduta gama, nota-se uma necessidade de utilização de elementos de seu repertório e experiências, que podem ou não estar ligadas diretamente com a questão do ensino/aprendizagem. Nesse momento ocorre a reorganização dessas idéias para a elaboração de um plano didático que solucione a perturbação original.

Com sua validação na prática docente, o professor incorpora os novos esquemas surgidos em seu conjunto de hipóteses, entretanto, no caso da não validação em caráter experiencial, a perturbação persiste, sendo necessária uma nova organização dos elementos inerentes ao seu repertório.

Nesse ponto, voltamos a salientar que, mesmo no caso de perturbações alfa ou lacunares, onde, respectivamente ocorre a negação do problema de ensino surgido e a ausência de elementos para sua solução, as situações vividas pelo professor, ainda que não julgadas relevantes pelo profissional para pertencerem aos seus esquemas docentes, inserem-se como elementos de experiências vividas pelo professor. Desse modo, tais experiências não se tornam inutilizáveis, podendo, inclusive, ser utilizadas em momentos posteriores de reflexão com o surgimento de novas necessidades devido a um novo quadro sociocultural, onde o futuro docente encontra-se imerso.

A seguir, exporemos as conclusões e considerações finais desta pesquisa, baseadas nos resultados desta análise de dados, bem como nos referenciais teóricos que a alicerçaram. 


\section{CAPÍTULO VI}

\section{CONCLUSÕES E}

\section{CONSIDERAÇÕES FINAIS}


O presente trabalho apresenta como objetivo a análise da dinâmica dos processos criativos quando da elaboração de conhecimentos pedagógicos de conteúdo por parte de futuros professores de Física, bem como estabelecer alguns elementos inerentes a esses processos. Em um ponto de vista mais específico, procuramos observar tais dinâmicas com dois grupos de licenciandos em Física que cursaram a disciplina Metodologia do Ensino de Física II na Universidade de São Paulo (USP) e iniciaram o processo de estágio obrigatório durante o último semestre da graduação.

O estudo da criatividade, a nosso ver, demonstrou-se amplamente justificado na literatura da área e propostas curriculares nacionais, sendo amplamente solicitada aos professores durante sua carreira, como já inferido por Silva (2005). A necessidade de criação de interações inovadoras também já havia sido verificada em diversas pesquisas (SHULMAN \& SHULMAN, 2004 e PONTE \& CHAPMAN, 2006, p.e.), onde professores situados em um mesmo contexto formativo e profissional acabam por criar interações didáticas diferentes.

Nessa linha de pensamento, também enfatizamos nesse trabalho que a criatividade não é inata do indivíduo, podendo, desse modo, ser desenvolvida durante a formação inicial do professor de Física, buscando um docente com uma maior qualidade de repertórios que o auxiliem nas respostas ao dinâmico e imprevisto cotidiano docente, favorecendo sua autonomia e desenvolvimento profissional.

Dessa forma, no segundo capítulo deste trabalho, procuramos caracterizar a situação atual da formação do professor de ciências, focando, principalmente, o docente de Física; discutimos com maior ênfase os modelos formativos segundo Contreras (2002), onde os integrantes da carreira do magistério poderiam se enquadrar em patamares técnicos, no caso do profissional tratar sua prática como uma solução instrumental de problemas mediante a aplicação de conhecimentos teóricos previamente transmitidos, reflexivos, em situações onde o docente é capaz de refletir durante ou após sua prática, em relação a situações inéditas ocorridas, e ainda, os patamares críticoreflexivos, identificados nos casos em que o modelo reflexivo extrapola o ambiente fechado da sala de aula, atingindo os patamares sociais, econômicos e políticos onde a escola se insere.

Ainda no segundo capítulo, buscamos estabelecer uma revisão bibliográfica sobre os estudos na área do Conhecimento Pedagógico de Conteúdo (CPC ou PCK, em inglês), estabelecendo que tal conceito, conforme estabelecido inicialmente por 
Shulman (1986 e 1987), é tratado como "um caminho de conhecimento que é único para professores no que diz respeito ao conteúdo e sua transformação em instrução para que os alunos possam compreender(...)". Em representações de PCK mais recentes, como Shulman \& Shulman (2004), Abell (2007), Ball (2008) e Kind (2009), o PCK é ampliado, sendo uma interrelação entre as dimensões do contexto (especificidades do ambiente onde a intervenção educacional será realizada), pedagógicas (conjunto das metodologias empregadas pelo professor para tratar os tópicos relativos à disciplina) e de conteúdo (elementos relativos à temática, propriamente dita), quando da elaboração de um novo conhecimento pedagógico de conteúdo, sendo este último inserido em um patamar crítico-reflexivo, incluindo influências nas áreas externas à sala de aula, tais como a comunidade escolar e as políticas públicas.

No terceiro capítulo, visando a um aprofundamento na área específica da criação humana, constatamos que tal referencial apresenta dependência direta entre os fatores cognitivos internos e os culturais (cf. STOLTZ, 1999, DE LA TORRE, 1996 e BRAGA, 1995, p.e.), o que nos permitiu estabelecer duas grandes fontes de referência para cada uma destas vertentes.

No tocante à vertente cognitiva, ligada à reestruturação de esquemas internos do sujeito, a teoria de equilibração piagetiana nos pareceu eficaz e adequada em relação ao tratamento da incorporação de fatos novos nos esquemas cognitivos do indivíduo. Tal ponto de vista trata o ato de criação humano como resultado de um desequilíbrio promovido frente a situações inéditas e imprevistas que adentram nos esquemas mentais do indivíduo, produzindo assimilações e adaptações que procuram superar o conflito criado. Vale ressaltar que, para Piaget, tão importante quanto o conflito para o desenvolvimento interno do indivíduo, encontram-se as lacunas - situações onde o esquema cognitivo do sujeito não apresenta repertórios suficientes para a resolução da instabilidade surgida.

Em relação à vertente cultural, optamos pela utilização da psicologia vigotskiana, haja vista que a teoria de equilibração piagetiana, apesar de considerar o meio social do indivíduo como possível fator deflagrador de conflitos, não o questiona profundamente enquanto sociedade, com comportamentos e fatores culturais próprios que influenciariam na criação dos sujeitos. Nesta etapa, corroboramos com o ponto de vista neo-piagetiano de Castorina (2008), onde as especificidades do meio cultural do 
docente são capazes de trazer instabilidades aos esquemas mentais do indivíduo, elaborando-se o conflito de natureza sociocognitivo.

Ainda em relação aos elementos sócio-culturais que permeiam o ato criativo, para Vigotsky, a criação é fruto do repertório e experiências vividas pelo indivíduo em um plano mental, os quais desaguarão em criações reais, chamadas de imaginação cristalizada. Ainda para o autor, tais criações poderiam ocorrer em dois níveis distintos: o reprodutor, caracterizado por elaborações baseadas em cópias de criações já existentes no sistema mental do sujeito, e o combinador/criador, onde as criações são frutos das experiências e repertórios vividos, porém com a utilização de adaptações ao novo contexto, ocorrendo em patamares de maior originalidade.

Dessa forma, apesar de utilizarmos duas teorias consideradas, tradicionalmente incompatíveis, focamos elementos de ambos os autores, a nosso ver, complementares, na tentativa de elaborar um referencial teórico específico para o estudo da criatividade no campo da formação de professores. Tal base nos permite visualizar a criação docente como fruto de funções cognitivas internas, que permitiriam a inserção de situações imprevistas geradoras de conflitos no sistema mental do professor, bem como abranger as fundamentais questões culturais, que localizariam o ato criativo do professor em um contexto social, com influências e fatores próprios.

Em nosso ponto de vista, a criação docente, em uma visão cognitivo-cultural, ocorre devido à inserção de situações imprevistas na prática docente, promovendo instabilidades nos esquemas mentais do professor, que possibilitarão o surgimento de conflitos e necessidades docentes para a resolução da perturbação instalada. Desse modo, tratamos o ato criativo como uma atividade (RIGON, 2009) criadora, tomandose o sentido mais estrito do conceito de atividade definido, inicialmente, por Vigotsky como o conjunto de ações movidas por uma necessidade legítima, levando o indivíduo a alcançar objetivos iguais aos motivos geradores da necessidade inicial.

Em suma, baseado nos referenciais citados anteriormente, iniciamos a pesquisa de campo de caráter qualitativo, realizada com um grupo de estagiários do último semestre da licenciatura em física da Universidade de São Paulo (USP) que cursavam a disciplina de Metodologia do Ensino de Física II, oferecida pela Faculdade de Educação da citada instituição. 
O processo de estágio desenvolvido ocorre em um nível investigativo (ABIB, 2010) e supervisionado (ABIB et al, 2011), ou seja, os licenciandos, além de promover intervenções relativas ao ensino em salas de aula do ensino médio, deveriam, com base nestas aulas, responder a uma questão exploratória de pesquisa relativa ao ensino de Física, desejando-se, desta maneira, incentivar os futuros docentes a serem pesquisadores de sua própria prática, mediante resposta a questões significativas para os mesmos (ABIB, 2002). Tais práticas são acompanhadas em reuniões semanais de supervisão, onde os futuros professores possuem um ambiente propício à discussão e exposição de suas experiências em ambiente escolar, juntamente com um supervisor e os demais licenciandos.

Os grupos de estagiários analisados, nomeados de Grupo I e Grupo II, compostos, respectivamente, pelos licenciandos ( $\mathrm{R}$ e C) e (A, L e W), tiveram os relatos de suas aulas analisados durante as citadas reuniões semanais de supervisão, que ocorriam após a aula de Metodologia do Ensino de Física II, as entrevistas finais realizadas após o término da disciplina, as aulas de Metodologia do Ensino de Física II, propriamente ditas, além dos portfólios produzidos, também entregues após a finalização das atividades do estágio. Todos os episódios selecionados, a partir destes instrumentos de pesquisa, buscavam identificar os momentos de criação dos licenciandos durante o processo de estágio, seja em sala de aula ou nos momentos de preparação das atividades que seriam desenvolvidas na escola.

A prática dos estagiários citados também nos proporcionou a possibilidade de caracterizar alguns elementos docentes surgidos durante o estágio, os quais nos forneceram indícios de elaborações de Conhecimentos Pedagógicos de Conteúdo relacionados às suas dimensões de conteúdo, contexto e pedagógica.

Os resultados obtidos nos permitiram constatar uma corroboração com os referenciais teóricos específicos da criatividade (PIAGET, 1972 e VIGOTSKY, 2009), obtendo episódios de criação por parte dos estagiários relacionados aos seus repertórios e experiências vividas. Também ressaltamos que obtivemos êxito em identificar situações de instabilidades por parte dos licenciandos antes de suas criações - as perturbações lacunares e conflituosas, sendo estas últimas geradoras de condutas alfa, beta e gama (PIAGET, 1976), permitindo-nos inferir acerca da existência de possíveis conflitos (PIAGET, 2002 e CASTORINA, 2008) que geraram uma necessidade (RIGON, 2009 e VIGOTSKY, 2009) criativa docente. 
A análise dos resultados também nos permitiu concluir que, no caso dos grupos de estagiários analisados, as necessidades de criar intervenções que superassem os conflitos surgidos dependiam do contexto social e cultural onde se encontrava o futuro professor. No caso específico do planejamento de atividades para serem aplicadas em sala de aula, constatamos que, quando movidas por perturbações geradoras de conflitos (conduta gama), a necessidade do futuro docente pareceu estar vinculada a uma melhora na aprendizagem dos alunos. Tais criações nos remeteram ao nível combinador vigotskiano, onde, apesar de utilizar-se de repertórios e experiências vividas, faz-se necessária a adaptação de alguns elementos ao contexto da intervenção didática.

No caso específico do ambiente cultural da sala de aula, referente à prática docente, os estagiários analisados trouxeram elementos que nos fizeram inferir acerca da dinâmica própria com que a troca de informações ocorre neste ambiente, que pressionava o futuro professor a solucionar rapidamente as instabilidades de natureza gama surgidas.

Dessa forma, tais perturbações acabaram fazendo com que os licenciandos, quando desestabilizados por tais situações defronte à turma onde ministraram suas aulas, buscassem criar formas de solucionar este conflito com base em exemplos já prontos em seus esquemas mentais, normalmente relacionados a modos de agir de seus professores de ensino básico ou graduação, quando submetidos à situação semelhante. Tais momentos de criação nos remetem a uma proximidade com o nível reprodutor vigotskiano, onde o criador se utiliza da cópia de repertórios anteriores para aplicação direta na situação de contexto atual, realizando poucas ou mesmo, nenhuma adaptação.

Vale ressaltar, porém, que neste trabalho, interpretamos os níveis criativos vigotskianos como os extremos de um espectro contínuo da criação, onde o nível reprodutor representaria o ato criativo cópia de um modelo anterior, sem qualquer adaptação. No percurso até o nível combinador, o indivíduo insere, gradativamente, adaptações aos repertórios de inspiração, aumentando o grau de originalidade de sua criação.

Dessa forma, enfatizamos que não se apresentou, nesta pesquisa, o objetivo de caracterizar uma interação como muito ou pouco criativa em relação à outra, tampouco inferir sobre uma pretensa maior eficiência de interações muito originais em decréscimo daquelas mais reprodutoras. As criações, conforme expomos, são fruto de interações cognitivas internas do sujeito, mas também ocorrem devido às necessidades culturais e 
sociais, ou seja, o contexto da criação deve ser levado em consideração, quando de sua análise.

Face ao exposto, optamos por expor os Caminhos Criativos traçados pelos grupos de estagiários analisados, caracterizando os elementos formadores do contexto social e cultural onde ocorreram os atos de criação, bem como as perturbações, conflitos e necessidades docentes geradoras em cada situação.

Salientamos também, que, em convergência com o referencial teórico adotado, procuramos categorizar os Caminhos Criativos analisados de acordo com as perturbações iniciais que os geraram, bem como as condutas seguidas pelos futuros professores. Tais situações, à luz da psicologia piagetiana, acabaram por gerar os Caminhos Criativos Lacunar, Alfa, Beta e Gama, de acordo com a natureza das perturbações e condutas do licenciando em face destas instabilidades.

Durante a análise destes Caminhos Criativos, deparamo-nos com episódios que se relacionavam com o desenvolvimento profissional dos futuros docentes durante a realização do processo de estágio. Tais episódios nos levaram a indícios de elaborações de elementos de cunho experiencial por parte dos licenciandos, que nos forneceram uma caracterização, ainda que prévia, das dimensões formadoras e influenciadoras de seus Conhecimentos Pedagógicos de Conteúdo, não sendo possível, entretanto, o aprofundamento desse último, devido a limitações da metodologia empregada, que buscou focar a dinâmica criativa.

Em um ponto de vista específico, verificamos que as situações de conflito vivenciadas em sala de aula, pelos estagiários analisados nessa pesquisa, nos permitiram constatar que as criações elaboradas apresentavam como necessidade fundamental ao futuro docente, sua sobrevivência (HUBERMAN, 1992) à aula, sendo crucial ao estagiário manter a disciplina na turma. Como já exposto, tais criações remetiam-se a exemplos já prontos, de rápida aplicação (BEACH \& PEARSON, 1998) e de eficácia confirmada para situações aparentemente semelhantes. Dessa forma, podemos inferir acerca da utilização, por parte do licenciando, de elementos de seus conhecimentos do contexto para a obtenção de uma metodologia de ensino mais adequada para o ensino do conteúdo específico naquela situação.

Tal fato nos traria, portanto, indícios para esboçar a elaboração de Conhecimentos Pedagógicos de Conteúdo de caráter Transformativo (GESS- 
NEWSOME, 1999), haja vista que o professor, mediante a utilização de exemplos e conhecimentos experienciais, elaborou uma intervenção para a resolução daquela situação específica. Tal PCK caracterizou-se, principalmente, pela não percepção, por parte do licenciando, das dimensões contexto, pedagógica e do conteúdo de maneira explícita, não sendo possível a identificação independente de cada um desses componentes.

Analogamente, também constatamos a elaboração de Conhecimentos Pedagógicos de Conteúdo em um patamar Integrativo (GESS-NEWSOME, 1999), concentrados em momentos de planejamento do plano didático, onde foi possível verificar, explicitamente, o PCK como fruto da união, em separado, do conhecimento específico de conteúdo, do contexto e das estratégias pedagógicas, necessitando adaptação à metodologia de ensino e visando à aplicação de uma nova intervenção. Tal integração seria advinda de caminhos criativos coerentes com tais elaborações e adaptações, exigindo, por parte do docente, necessidades de criação em patamares mais afastados do nível reprodutor vigotskiano.

Nessa linha específica de pensamento, a literatura específica acerca da utilização dos Conhecimentos Pedagógicos de Conteúdo na formação inicial de professores traz autores que enfatizam o uso de PCK integrativos como fundamentais à formação do futuro docente (GESS-NEWSOME, 1999, p.e.), bem como aqueles que defendem os PCK transformativos como fortes aliados na formação inicial, especificamente do professor de ciências (KIND, 2009, p.e.).

No caso do primeiro ponto de vista, Gess-Newsome (op.cit.) nos remete à necessidade fundamental do futuro professor em possuir suas bases de conhecimentos (contextual, pedagógica e de conteúdo) bem alicerçadas, podendo refletir, independentemente sobre cada uma delas para, posteriormente, unificá-las na elaboração de seu PCK. Já em relação a uma maior utilização do patamar transformativo na formação docente científica, Kind (op.cit.) defende esse tipo específico de conhecimento como potencial fator causador de reflexões rápidas sobre o conteúdo abordado e o ambiente de sala de aula, fazendo com que o futuro docente ingresse no mercado de trabalho com um conjunto de estratégias mais diretas para o exercício do magistério.

A análise dos resultados de nosso trabalho aponta para um equilíbrio entre estas duas dimensões de Conhecimentos Pedagógicos de Conteúdo, sendo que, durante a 
formação inicial, em nosso ponto de vista, ocorre a necessidade do futuro professor se envolver com os imprevistos e situações inéditas características da prática docente em sala de aula, estabelecendo conhecimentos transformativos de rápida resposta às instabilidades surgidas e que se somarão aos demais conhecimentos, enriquecendo seu repertório e facilitando criações posteriores. Da mesma forma, os relatos dos estagiários apontaram que Conhecimentos Pedagógicos de Conteúdo de natureza integrativa são igualmente necessários ao futuro professor, favorecendo reflexões mais profundas acerca dos processos de ensino e aprendizagem durante as necessárias adaptações de conteúdo que permeiam o cotidiano docente.

Tais adaptações de conteúdo, entretanto, só poderão ser uma realidade se estivermos tratando de uma formação inicial docente em caráter, minimamente, reflexivo e com alto grau de conhecimento específico de conteúdo. Sem este binômio, torna-se improvável um futuro professor criar, transitar, refletir e efetuar adaptações sobre as várias áreas de seu conhecimento específico, sem um bom domínio deste último.

Em suma, é preciso que os cursos de formação inicial se preocupem no fornecimento de uma gama de elementos ao futuro professor, propiciando o contato com situações comuns e inéditas ao ambiente de sala de aula, fato este que viria a colaborar com o fortalecimento do repertório docente e minimização de possíveis lacunas. Da mesma maneira, deve-se incentivar um profundo conhecimento do conteúdo, propiciando ao futuro docente uma maior facilidade de adaptações e mudanças, inclusive, no decorrer da aula, além de propiciar maior autoconfiança (KIND, 2009) e possibilidades ao docente de compreender melhor as dúvidas e colocações de seus alunos.

Neste ponto, também ressaltamos a importância das reuniões de supervisão no desenvolvimento profissional dos estagiários. Nesses encontros semanais, verificamos frutíferas trocas de informações entre os licenciandos e o professor supervisor e, também, entre os próprios licenciandos, criando oportunidades para que aqueles com maior grau de experiência ou repertório pudessem efetuar troca de informações com os demais, remetendo-nos às Zonas de Desenvolvimento Proximal - ZDP (VIGOTSKY, 2001).

Tal caráter coletivo na realização dos estágios também é corroborado por Abib (2002), onde esta prática permite aos futuros professores vivenciarem momentos que 
envolvam a cooperação e a negociação de diferentes pontos de vista, interesses e valores, na busca de soluções para os problemas em debate, de modo que possam ser desenvolvidas capacidades de argumentação, atitudes de respeito às diferenças e postura ética.

Ressaltamos também a importância que os conteúdos trabalhados nas aulas de Metodologia de Ensino de Física II trouxeram aos futuros professores, que, em diversos momentos, se utilizavam de tópicos abordados durante essa aula da graduação nas intervenções didáticas criadas, reiterando, em convergência com as hipóteses tratadas na psicologia vigotskiana (VIGOTSKY, 2009) e elementos da teoria histórico-cultural (RIGON, 2009), a importância dos fatores relacionados ao entorno cultural onde se encontra o estagiário, não limitando seu ambiente apenas à sala de aula.

Tanto as reuniões de supervisão, como os elementos fornecidos pela disciplina "Metodologia do Ensino de Física II", são formadores de um quadro mais amplo - o estágio com caráter investigativo (ABIB, 2010). Tal visão do processo de estágio, corroborada inclusive pela Lei de Diretrizes e Bases da Educação Nacional (BRASIL, 1996, art. 3ㅇ, inciso II), busca integrar a pesquisa exploratória em Ensino de Física à prática dos licenciandos em sala de aula, buscando constantes reflexões dos estagiários em relação a seu papel, enquanto educador. De fato, os episódios analisados nos permitiram constatar o quão frutífero tais reflexões se demonstraram para o surgimento de conflitos de natureza sociocognitiva no ambiente educacional.

Nesse ponto, defendemos também a antecipação do contato dos licenciandos com o ambiente escolar. De fato, a própria resolução CNP/CP (BRASIL, 2002) prevê que “(...) a prática deverá estar presente desde o início do curso e permear toda a formação do professor". Tal antecipação destes momentos parecem se mostrar fundamentais em relação ao aumento de tempo que os docentes do curso de graduação, responsáveis por estas atividades, possuiriam para aprofundar a discussão, análise e solucionamento dos conflitos surgidos no contexto experiencial.

Desse modo, o trabalho em tela, por se tratar de uma pesquisa de cunho qualitativo acerca das dinâmicas dos processos de criação, acabou por efetuar uma análise envolvendo o trajeto de estágio de dois grupos de alunos da licenciatura em Física da Universidade de São Paulo. Apesar de, no início, apontarmos para o estudo de uma problemática mais ampla no tocante ao estudo da criatividade, acabamos por focar em uma das possibilidades de criação, analisando os caminhos criativos específicos de 
grupos de estagiários ao regerem suas aulas pela primeira vez. Tal análise, se aprofundada, poderia apontar maiores detalhes sobre os Conhecimentos Pedagógicos de Conteúdo elaborados pelos licenciandos, bem como outros elementos inerentes ao ato criativo docente.

Pesquisas posteriores poderiam, portanto, aprofundar-se neste quadro, mais precisamente no tocante aos mecanismos de criação dos futuros professores em contextos diferentes, tais como a sala de aula ou em seus momentos de planejamento, buscando um enfoque maior nos fatores culturais que potencializariam o surgimento de situações de instabilidade. Da mesma forma, seria de interesse acadêmico a análise dos processos criativos realizados por professores mais experientes nos mesmos contextos, procurando a montagem de um quadro mais completo sobre estes momentos de criação que permeiam o magistério.

Em suma, a aprendizagem da docência, relacionada aos processos criativos, requer, portanto, especial atenção aos problemas de ensino deflagradores dos processos de criação. Tais perturbações, segundo os trajetos desenvolvidos pelos estagiários e analisados nessa pesquisa, ao se confrontarem com as hipóteses docentes iniciais podem ser capazes de gerar conflitos, possibilitando a elaboração de novos esquemas de conhecimentos, bem como manter as hipóteses já existentes, após testes de validação na prática da ação docente.

Nessa linha de pensamento, o entorno onde está inserido esse licenciando também se demonstrou capaz de apresentar elementos culturais específicos que influenciam a forma como o estagiário poderá (ou não) superar o conflito instaurado. Tal fato deve ser acompanhado e supervisionado pelo seu formador, permitindo ao estagiário, momentos de discussão e reflexões que tratem a superação dessas situações conflituosas, ou mesmo, daquelas onde o conflito não se configurou, uma vez que, mesmo estas últimas, farão parte do repertório mais geral do licenciando, podendo se transformar em possíveis causadoras de conflitos futuros.

Ainda em relação ao ponto de vista do formador do docente em Física, ressaltamos a atenção que deve ser dada a um conjunto específico de perturbações que nos parecem se repetir com estagiários em seu primeiro contato com a sala de aula - a indisciplina, o planejamento do tempo didático e a utilização da matemática. Tais preocupações, por demonstraram-se recorrentes na literatura específica e também observadas com os licenciandos analisados, sugere uma maior atenção do formador para 
esses pontos, haja vista ter sido constatada a instauração de necessidades legítimas por parte dos futuros docentes visando à solução de situações de instabilidade geradas quando da ocorrência destas perturbações.

Desse modo, esse trabalho identificou conflitos ocorridos com estagiários em ambientes de sala de aula, que se demonstraram propícios à construção de novos Conhecimentos Pedagógicos de Conteúdo Transformativos relacionados à questão da sobrevivência docente (HUBERMAN, 1992), assim como em situações de planejamento do plano didático, fora da sala de aula, que apontaram para a elaboração de Conhecimentos Pedagógicos de Conteúdo Integrativos relacionados a uma maior preocupação com a aprendizagem discente por parte dos futuros docentes.

Portanto, é fundamental ao formador de professores que, durante o processo de estágio, tenha consciência dessa gama de fatores que influenciam o processo de criação de novos conhecimentos em seus formandos. Dessa forma, deve-se buscar o planejamento consciente de intervenções, situadas de acordo com os elementos socioculturais do meio onde se insere o futuro professor, trazendo problemas de ensino significativos e que possam respeitar as necessidades legítimas da fase docente em que se encontram os estagiários, favorecendo, dessa forma, uma gradual, porém sólida, ampliação dos esquemas docentes, objetivando seu desenvolvimento profissional.

Ser professor é estar preparado para o não preparável, é estar continuamente planejando aquilo que, a qualquer momento, pode se tornar não planejável, é estar pronto para criar e recriar sobre os novos elementos que surgem durante sua prática profissional. Ser professor é trabalhar com o imprevisível e aprender com ele. É o magistério... nos pregando peças todos os dias... 


\section{REFERÊNCIAS}

\section{BIBLIOGRÁFICAS}


ABELL, S.K. Research on Science Teacher Knowledge in Handbook of Research on Science Education. 2007.

ABIB, M.L.V.S. A Pesquisa em Ensino de Física e a sala de aula: articulações necessárias na formação de professores in: GARCIA, R. et al, A Pesquisa em Ensino de Física e a sala de aula: articulações necessárias. Anais do XI EPEF. Curitiba. 2010.

A contribuição da prática de ensino na formação inicial de professores de física. In: Dalva E. Gonçalves Rosa; Vanilton Camilo de Souza. (Org.). Didáticas e práticas de ensino: interfaces com diferentes saberes e lugares formativos.. $1^{\mathrm{a}}$ ed. Rio de Janeiro e Goiânia.: DP\&A Editora e Editora Alternativa, 2002, v. , p. 188-204.

A Construção do Conhecimento sobre o Ensino na Formação do Professor de Física - "Agora nós já temos as perguntas". Tese (doutorado). FEUSP. 1997.

Em busca de uma nova formação de professores in: Formação de Professores de Ciências, 1996.

ABIB,M.L.V.S., CUNHA,A.M., TESTONI,L.A., Atividades de Experimentação e Modelagem em Estágio Investigativo e o Desenvolvimento de Conhecimentos Pedagógicos do Conteúdo In: Anais do VIII ENPEC, Campinas, 2011.

ALENCAR, E.S.. Criatividade, $2^{\text {a }}$ ed. Ed.UnB. 1995

ANDRÉ, M.E.D.A., A Etnografia da Prática Escolar. 4a Ed. Campinas. Ed. Papirus, 2000, 128p.

AROEIRA, K.P., O Estágio como Prática Dialética e Colaborativa: a produção de saberes por futuros professores, Tese de Doutorado, São Paulo, FEUSP, 2009.

ASTOLFI, J.P. Trois Paradigmes Pour Les Recherches en Didactique, Revue Française de Pédagogie, n.103, pp.5-18, 1993. 
BACA, L., PAIXÃO,F., ONOFRE, M. Desenho Metodológico de um Estudo sobre o

Conhecimento Pedagógico do Conteúdo de Professores e a Qualidade do Ensino na Disciplina de Química com a $7^{\circ}$ Classe no sistema Educativo Angolano in Atas do XIII ENEC, Portugal, 750-761, 2007.

BALL, L., THAMES, M., PHELPS, G., Content Knowledge for Teaching: what makes it special? In Journal of Teacher Education, v.59, n.5, 389-407, 2008.

BAUMERT, J. Teacher's Mathematical Knowledge, Cognitive Activation in the Classroom and student Progress in American Eucation Research Journal, v.47, n.1, 133-180, 2010.

BEACH, R., PEARSON, D. Changes in Preservice Teacher's Perceptions of Conflicts and Tensions. Teaching and Teacher Education, v.14, n.3, p.337-351, 1998.

BEJARAnO,N.R, CARVAlHO, A.M.P. Tornando-se Professor de Ciências: crenças e conflitos. Ciência e Educação, v.9, n.1, p.1-15, 2003.

BICUDO, M.A.V. Educação Matemática. $2^{\circ}$ ed., Centauro Editora, 2005.

BRAGA, M.P.J.G., Inteligência e Criatividade: a dialética da criação, FEUSP, 1995.

BRASIL, Lei 9394/96 de 20 de dezembro de 1996. Lei de Diretrizes e Bases da Educação Nacional, $\quad$ Brasília: $1996 . \quad$ Disponível em www.planalto.gov.br/ccivil_03/leis/L9394.html . Acessado em 14 de setembro de 2013 , Parâmetros Curriculares Nacionais, Ministério da Educação e Cultura, 1997. Resolução CNE/CP, Ministério da Educação, Brasília, 2001. Resolução CNE/CP, Ministério da Educação, Brasília, 2002. 
BOGDAN, R. \& BIKLEN, S. Investigação Qualitativa em Educação: uma introdução à teoria e aos métodos, Porto Editora, 1994.

BOSKURT, O. \& KAYA, O.N. Teaching about Ozone Layer Defletion in Turkey: pedagocical content knowledge of science teachers in Public Understanding of Science, n.17, 261-276, 2008.

BRONOWSKI, J. Arte e Conhecimento: ver, imaginar e criar, ed. Martins Fontes, 1983.

Ciência e Valores Humanos, ed. Itatiaia, 1974.

CARMO, A.B., Construindo a linguagem gráfica em uma aula experimental de física in Ciência e Educação, v.15, n.1, 2009

CARVAlHO, A.M.P. As Pesquisas em Ensino de Ciências e suas Influências na Formação Docente. São Paulo, FEUSP, 2000.

Enculturação Científica: uma meta do ensino de ciências in atas do XIV Endipe, 2009.

Uma Metodologia de Pesquisa para Estudar os Processos de Ensino e Aprendizagem em Sala de Aula, in SANTOS, F \& GRECA, I, A Pesquisa em Ensino de Ciências no Brasil e suas Metodologias, Unijuí, 2006.

CASTORINA, J.A., BAQUERO, R., Dialética e Psicologia do Desenvolvimento: o pensamento de Piaget e Vigotsky, Ed. Artmed, 2008, 214pp.

O debate Piaget-Vigotsky: a busca de um critério para sua avaliação in et al, Piaget- Vigotsky: novas contribuições para o debate.

Ed. Ática. $6^{\text {a }}$ Ed. 2008, 175pp. 
CHARLOT, B. Educação e Globalização: uma tentativa de colocar ordem no debate. Sísifo/Revista de Ciência e Educação, n 4, p. 129-136. 2007.

COCHRAN, L., DERUITER, J. Pedagogical Content Knowing: an integrative model for teacher preparation in Journal of Teacher Education, n.44, 263-270, 1993. COCHRAN, K., JANES, L. The Subject Matter knowledge of Preservice Science Teachers in FRASER,B.\& TOBIN, K (Eds), International Handbook of Science Education, London: Klwer Academic Publishers, 707-718, 1998.

COLL, C., Aprendizaje escolar y construcción del conocimiento. Buenos Aires, Paidós, 1990.

CONTRERAS, R. A autonomia dos professores. Ed. Vozes, 2002.

DE LA TORRE, S. Para investigar la creatividad: thesaurus y bibliografia, Española, Barcelona, PPU, 1996.

DEnZIN, N. \& LINCOLN, Y., O Planejamento da Pesquisa Qualitativa: Teorias e Abordagens. Porto Alegre, Artmed, 2006.

DIJJK, E.M., KATTMANN, V. A Research Model for the Study of Research Teacher's PCK and Improving Teachers Education in Teaching and Theacher Education, n.23, 885-897, 2007.

DINIZ-PEREIRA, J.E. A Pesquisa dos Educadores como Estratégia para a construção de modelos críticos de formação docente. In: , Zeichner, K.M. (orgs), A pesquisa na formação e no trabalho docente. Ed. Autêntica. Belo Horizonte. 2002. 200p.

DRIEL, J., VERLOOP, N., VOS, W. Developing Science Teacher's PCK in Journal of Research in Science Teaching, v.35. n.6, 1998. 
ERICKSON, F. Qualitative Research Methods for Science Education, KAP, 1998.

FERREIRO, E. Psicogênese da escrita in COLL, C., Psicologia genética e aprendizagens escolares. Madrid.1983.

Luria e o desenvolvimento da escrita na criança, cadernos de pesquisa, 88, 72-77, 1994.

FERRETTI, C. J., A Inovacao Na Perspectiva Pedagógica. Cortez Editora e Autores Associados, pp. 55-68, 1980.

FOUREZ, G. Crise no ensino de ciências? In Investigações em Ensino de Ciências, V8(2), pp. 109-123, 2003.

FREIRE, P. Pedagogia da Autonomia, Ed. Vozes, 2006.

FULLER, F.F., Concerns of Teachers: a developmental conceptualization. American Educational Researchers Journal, n.2, p.207-226, 1969.

GARRITZ, A. PCK and the Affective Domain of Scholarship of Teaching and Learning in International Journal for the Scholarship of Teaching and Learning, v.4. n.2, 2010 .

GROSSMAN, P.L. The Making of a Teacher: teacher knowledge and teacher education , New York: Teacher College, 1990.

GUESS-NEWSOME, J., Examining Pedagogical Content KnowledgP: the construct and its implications for science education, Association for Education of teachers in science, 306pp., 1999.

GUIMARÃES, L.A.M. Concepções Prévias x Concepções “oficiais" na Física do $2^{\circ}$ grau, Dissertação (mestrado). UFF. Niterói, 1987. 
HERNANDEZ, T. El Profesor Experto e su Estrutura a Del de Conocimiento através de um Proceso de Instrución, v.3. n.2, 1992.

Huberman, M. O Ciclo de Vida Profissional dos Professores. In Nóvoa, A. (org.), Vida de Professores, $2^{\text {a }}$ Ed., Porto, Portugal, Porto Ed., p.31-61.

HUBERMANN, A.M. Como se realizam mudanças em educação: subsídios para o problema da inovação, Ed. Cultrox, São Paulo, 1976.

JAPIASSU, Ricardo. Metodologia do Ensino de Teatro. Campinas: Papirus, 2001.

JOHNSON, R. B., ONWUEGBUZIE, A. J., Mixed methods research: A research paradigm whose time has come. Educational Researcher, 33(7), 14-26, 2004.

JORDÃO,R.S. Tutoria e Pesquisa-Ação no estágio supervisionado: contribuições para a formação de professores de biologia. Tese de Doutorado. FEUSP. 2005.

JUSTO, J.S., Criatividade no Mundo Contemporâneo in VASCONCELOS, M. (org.), Criatividade: psicologia, educação e conhecimento do novo. Ed. Moderna. 2001.

KIND, U. Pedagocical Content Kwowledge in Science Education: perspectives and potential for progress in Studies on Science Education, 45(2), 169-204, 2009.

KNELLER, J. A ciência da criatividade, ed. Vozes, São Paulo, 1978.

KRASILCHIK, M. O professor e o currículo das ciências. São Paulo: EPU: Editora da Universidade de São Paulo, 1987.

LEONTIEV, A. O desenvolvimento do psiquismo. Ed. Moraes, s/d.

LERNER, D. O Ensino e o Aprendizado Escolar: argumentos contra uma falsa oposição in CASTORINA, et al, Piaget- Vigotsky: novas contribuições para o debate. Ed. Ática. 6a Ed. 2008, 175pp. 
LIBÂNEO, J.C., A didática e a aprendizagem do pensar e do aprender: a teoria histórico-cultural da atividade e a contribuição de Vasily Davydov in Revista Brasileira de Educação, n.27, 2004.

LIMA FIHLO, A., REBOUÇAS, F.A. O Pensamento formal em Piaget: gênese, estruturação e equilibração. Goiânia, Dimensão, 1988.

LÜDKE, M. \& ANDRÉ, M.E.D.A. Pesquisa em Educação: Abordagens Qualitativas, E.P.U.,11 ${ }^{\mathrm{a}}$ ed. 2008.

MACEDO, L., Afetividade, Cognição e Conduta na Prova Operatória de Seriação. Revista Eletrônica de Psicologia e Epistemologia Genéticas, n.2, disponível em www.marília.unesp.br/scheme. acessado em 12 de abril de 2013.

MAGNUSSON, S., KRAJICK, J., BORKO, H. Nature, Sources and Development of PCK for Science Teaching in GESS-NEWSOME \& LEDERMAN (Eds), Examining PCK: the construct and the implications for science education, 95-132, Klwer Academic, Netherland, 1999.

MARANDINO, M. SELLES, S.E.; FERREIRA, M.S. Ensino de Biologia: histórias e práticas em diferentes espaços educativos. São Paulo: Cortez, 2009.

MARCON, D., GRAÇA, A.B.S., NASCIMENTO, J.V. Busca de Paralelismo entre Conhecimento Pedagógico do Conteúdo e Processo de Raciocínio e Ação Pedagógica in Educação em Revista, v.27, n.1, 261-294, 2011.

MATOS FILHO, M.A.S. A transposição didática em chevallard:as deformações/transformações sofridas pelo conceito de função em sala de aula in anais do Educere. Recife. 2008.

MEDEIROS, C.F., Por uma Educação Matemática como intersubjetividade in 
MENDES, A.M. O desenvolvimento criativo in Revista Espaço Acadêmico, São Paulo, 2005.

MIZUKAMI, M.G.N. Ensino: as abordagens do processo. EPU, São Paulo, 1986.

MORAES, V. Estágio e Supervisão Ecológica: crenças e saberes na aprendizagem da docência. Tese. FEUSP. 2009.

MORIN, E. Os Sete Saberes Necessários à Educação no Futuro, Cortez Editora, 2a Ed. São Paulo, 2000.

MORTIMER, E.F., CARVALHO, A,M,P., Referenciais teóricos para análise do processo de ensino de ciências in cad.pesq., São Paulo, n.96, 1996, p.5-8.

PARIS, S. \& CROSS, D. The zone of proximal development: virtues and pitfalls of a metaforical representation of children's learning in The Genetic Epistemologist, University of Delaware, XVI(1), 1988.

PEREIRA, M.I.G.G. Emoções e Conflitos: Análise da Dinâmica das Interações numa Classe de Educação Infantil. Tese de Doutorado, Faculdade de Educação, Universidade de São Paulo, 209pp., 1998.

PIAGET, J., Epistemologia Genética, Ed. Martins fontes, $2^{\text {a }}$ Ed., 2002. 124pp. Psicogênese e História da Ciência, Difusão Europeia do Livro. 1981. $157 \mathrm{pp}$

A Equilibração das Estruturas Cognitivas: problema central do desenvolvimento, Rio de Janeiro: Zahar, 1976.

, Adónde va la Educación, Barcelona, Teide, 1974. 
, Jean Piaget in Criatividade: psicologia, educação e conhecimento do novo.

Ed. Moderna. 2001.

, Psicología y pedagogia. Barcelona, Ariel. 1969.

\& Inhelder, B., Psicologia da Criança. Difusão Europeia do Livro. 1968. 150pp.

PIETROCOLA, M. Inovação Curricular em Física: Transposição Didática e a Sobrevivência dos Saberes in Garcia ET al, A Pesquisa em Ensino de Física e a sala de aula: articulações necessárias. SBF. pp. 115-125. 2011.

. Curiosidade e Imaginação: os caminhos do conhecimento nas ciências, nas artes e no ensino in CARVALHO, A.M.P., Ensino de Ciências: unindo a pesquisa e a prática, Ed. Thomson, 2004.

PIMENTA, S.G., Professor Reflexivo: construindo uma crítica. In: PIMENTA, S.G., GHEDIN, E. Professor Reflexivo no Brasil: gênese e critica de um conceito, São Paulo: Cortez, 2008.

Formação de Professores: identidade e saberes. In: PIMENTA, S.G. (org.), Saberes Pedagógicos e Atividade Docente, São Paulo: Cortez: 2002.

PIMENTA, S.G. E LIMA, M. S.L., Estágio e Docência. 5 $5^{\text {a }}$ Ed. São Paulo: Cortez, 2010.

Estágio e Docência, $3^{\text {a }}$ Ed. São Paulo: Cortez:

2004.

PONTE, J.P. E CHAPMAN, O. Teachers Knowledge and pratices in Handbook of reasearch on the Psycoogy of Mathematics Education. Sense Publishers, 2006. 
PORLÁN, A., GARCÍA, A.R., POZO, M., Conocimiento profesional y epistemologia de los profesores I: teoria, métodos y instrumentos in Enseñanza de las ciências, 15(2), pp.155-171, 1997.

QUEIRÓZ, G.R.P.C., Processos de Formação de Professores Artistas-reflexivos de Física in Educação \& Sociedade, n.74, 2001.

RAMOS, V., GRAÇA, A.B.S., NASCIMENTO, J.V. O Conhecimento Pedagógico de Conteúdo: estrutura e implicações à formação em educação física in Revista Brasileira de Educação Física, v.22, n.2, 161-171, 2008.

RIGON,A.J., O Desenvolvimento Psíquico na Teoria Histórico-Cultural, Editora UPF, 2009.

SANTOS, M.I., Reformulação Curricular no curso de Licenciatura em Química: fatores que contribuem para a configuração de um processo inovador. Dissertação de Mestrado. Universidade de São Paulo. 2009.

SAlaZAR, S.F. El Conocimiento Pedagogico de Contenido como Categoria de Estudio de la formación Docente in Actualidades Investigativas em Educación, vol. 5, n.2, 2005 .

SALES, M.G.P. Investigando o Conhecimento Pedagógico de Conteúdo sobre “Soluções” de uma Professora de Química. Dissertação, FEUSP, 2010.

SCHÖN, D. La formación de profesionales reflexivos. Hacia un nuevo disefio de la enseñanza y el aprendizaje en las profesiones. Bartcelona, 1992.

SFORNI, M.S.F.,Aprendizagem conceitual e organização do ensino: contribuições da teoria da atividade in Revista Ensino Fundamental, n.13, 2004. 
SHULMAN, L., Those who understand: knowledge growth in teaching. Educational Researcher, 15(2), 1986.

Knowledge and Teaching: Foundations of the New Reform in Harvard Educational Review. Vol. 57. N.1. 1987.

SHULMAN, L. \& SHULMAN,J., How and what teachers learn: A shifting perspective, Journal of Curriculum Studies, 36.2: 257-271, 2004.

SILVA, D. , Estudo das Trajetórias Cognitivas de Alunos no Ensino da Diferenciação dos Conceitos de Calor e Temperatura, Tese de Doutorado. FEUSP, 1995.

TARDIF, M. Saberes Docentes e Formação Profissional, Ed. Vozes, São Paulo, 2002.

TARDIF, M. \& RAYMOND, D. Saberes, Tempo e Aprendizagem do Trabalho no Magistério in Educação e Sociedade, n.21, 2000.

TESTONI, L.A., Um Corpo que Cai: as histórias em quadrinhos e o ensino de física, Dissertação de Mestrado. FEUSP. 2004. 158p.

ULMANN, D. Kurt Lewin: his impact on American psychology, or brinding the George between Theory and Reality. 2000. Disponivel em www.sonoma.edu/psychology/os2db/history3.html acessado em 26/03/2011.

UNIVERSIDADE DE SÃO PAULO (USP), Programa de Formação de Professores USP, São Paulo, 2004.

VASCONCELOS, M.S., (a) O Modelo Criativo de Piaget e Vigotsky in: (org.) ,Criatividade: psicologia, educação e conhecimento do novo. Ed. Moderna. 2001. 
VASCONCELOS, M.S. ,Criatividade: psicologia, educação e conhecimento do novo. Ed. Moderna. 2001.

VIGOTSKY, L. Criação e Imaginação na Infância. Ed. Vozes. 2009.

A Construção do pensamento e da linguagem, ed. Martins Fontes, São Paulo, 2001.

A formação Social da Mente, ed. Martins Forntes, São Paulo, 1989.

www.usp.br/jupiter acessado em 04/11/2012.

XAVIER, K,R, Criatividade e Inclusão na Formação de Professores in Revista CFCH/UFRJ, n.2, 2005.

ZEICHNER, K.M. A Pesquisa-ação e a formação docente voltada para a justiça social: um estudo de caso dos Estados Unidos In: In: Diniz-Pereira, J., Zeichner, K.M. (orgs), A pesquisa na formação e no trabalho docente. Ed. Autêntica. Belo Horizonte. 2002. 200p. 
APÊNDICES E ANEXOS 


\section{APÊNDICE 1 - TRANSCRIÇÃO PARCIAL DAS REUNIÕES DE SUPERVISÃO ESTAGIÁRIOS R e C (GRUPO I)}

TRANSCRIÇÃO DAS SUPERVISÕES - 2012 (17h40min - 18h30min)

\section{$1^{\text {a }}$ SUPERVISÃO (29 DE AGOSTO DE 2012)}

R: 3 min - Eu gostava muito de Física... principalmente no $3^{\circ}$ ano do ensino Médio eu percebi que gostava muito de Física. Aí eu fiz Física e passei, mas não foi aqui não... foi na universidade Estadual de Itajubá... aí eu fiquei lá dois anos e fiz transferência para cá. Entrei no bacharelado (em Física), fiz mais um ano, mais aí eu entrei em crise, comecei a trabalhar com outras coisas, pensei em desistir do curso... aí eu transferi para a licenciatura, pois do jeito que eu estava, achava que não ia dar consta de terminar o bacharelado, na licenciatura ia ser mais fácil para se formar... mas eu levei tão nas coxas, tão nas coxas, que não passava em nada. Agora já faz um ano em meio que eu to fazendo direitinho.

Pesq: 4min44s - Você já dá aula?

R: 4min45s - Não, aula não. A experiência que eu tenho com aula é só dos estágios, mesmo.

C: $5 \min 14 \mathrm{~s}$ - Eu entrei no Instituto em 2005, entrei no bacharel. Comecei fazendo 2 anos de engenharia em uma faculdade particular, mas achei o co muito nas coxas. Aí eu desisti... Fui trabalhar no banco Itaú, fiquei lá por cinco anos, trabalhava na área de cálculo de finanças, sempre gostei de matemática... mas chegou uma hora que eu enchi, não via futuro no que eu tava fazendo... tinha um primo meu que fazia doutorado aqui no IPEN e na suíça. Um dia me chamou para ver os laboratórios... aí eu fiquei encantado. È isso qiue eu vou fazer... comecei em Física bacharelado....fiz três anos, fazia três vezes cada matéria... aí entrei em um momento de crise, pensei em sair do curso, aí eu comecei a fazer a licenciatura; falaram que o curso na parte de cobrança, na teoria era mais tranqüilo... aí na mesma época eu comecei a dar aula no cursinho popular... foi em 2009... também dava aula em um cursinho preparatório para vestibulinho e, desde 1 ano e meio atrás, to me dedicando mais na faculdade para me 
formar agora. Hoje eu dou aula particular só e to montando uma escolinha de aula de reforço no Tatuapé.

R: $12 \min 55 \mathrm{~s}$ - A gente tem uma ideia do que trabalhar no estágio, mas o a gente ainda não conversou com a escola. $\mathrm{O}$ medo nosso é que a professora lá não goste da nossa ideia e a gente seja obrigado a mudar os nossos planos. O tema seria a física da propulsão. A Edéia era montar um curso... sabe aqueles foguetes movidos a ar, pressão, então, a ideia era montar um desses.

C: $13 \min 39 \mathrm{~s}$ - A gente teve essa ideia no curso de metodologia I, para depois aplicar na II. Quando a gente falou com a professora ela disse que a ideia não era fazer um minicurso, mas pegar esta parte teórica e experimental de quantidade de movimento e desenvolver com os alunos.

Pesq: $14 \min 29 \mathrm{~s}$ - tem uma ideia já, de como vão ser estas atividades?

C: $14 \min 41 \mathrm{~s}$ - Na verdade a gente começaria com esta parte de experimentos simples da conservação da quantidade de movimento... um exemplo que a gente já tinha desenvolvido na metodologia I era pegar dois skates, sentar um aluno em um, outro aluno no outro, encostarem as mãos e empurrar... então, seria uma das atividades a realizar...tem umas três ou quatro atividades para realizar e o foguete seria a atividade final.

Pesq: $15 \min 35 \mathrm{~s}-\mathrm{E}$ vocês pretendem avaliar esta atividade como?

C: $15 \min 40 \mathrm{~s}$ - O que serviu de inspiração para a gente é que, no final de cada aula a gente passaria um questionário para ver o que ele aprendeu, o que ele entendeu de cada experiência, da teoria.

C: $20 \min 15 \mathrm{~s}$ - A ideia da propulsão... no semestre passado, uma aluna minha que fazia aula particular comigo, pediu ajuda para desenvolver este foguete, e ela falou que o pessoal da sala ficou muito motivado com isso, um ia espionar o foguete do outro, ficavam discutindo se o bico do foguete fosse assim ele ia tombar... aí a gente pensou... será que a gente não conseguiria fazer algo parecido? 


\section{2a SUPERVISÃO (12 de Setembro de 2012)}

R: Eu fiz um projeto de estágio... apresentei lá na sala... A ideia era construir um foguete e fazer um foguete e explicar o mecanismo de propulsão, baseado na conservação do momento... a nossa ideia é ver, como a construção do foguete motiva os alunos do ensino médio...Tem várias aulas e, em cada aula, várias atividades. A gente ia fazendo estas atividades, durante elas fazer discussões. A avaliação... eu ainda não sei direito... a professora perguntou para gente sala de aula, mas eu ainda não sei como a gente vai fazer...Acho que a gente vai dar algum questionário para o aluno no fim da aula para ter com a gente... a gente vai falar com a professora amanhã, porque eu nem sei se ela vai me aceitar, onde ela ta na matéria, se ela já passou conservação do momento... a primeira aula a gente ia mostrar uns vídeos, na segunda a gente ia colocar um aluno em um skate, outro em outro e fazer a discussão, a terceira aula seria experimental, com uma bexiga... a gente enche a bexiga, solta, ela sai voando e agente ia explicar porque ela sai voando usando a conservação do momento, a próxima seria uma aula com problema de lápis e papel e a última a construção do foguete.

\section{$3^{\text {a }}$ SUPERVISÃO (26 de Setembro de 2012)}

C: $1 \min 22 \mathrm{~s}$ - A princípio a gente falou com a professora e ela já tinha dado o conteúdo de quantidade de movimento. A gente ia mudar para termodinâmica, astronomia, natureza da luz, mas quando a gente mostrou o projeto inteiro para a professora, ela falou: Ah, não! Quero esse! Então a gente vai fazer sobre a propulsão, mesmo.

Pesq: $1 \min 59$ s - E ela vai voltar o conteúdo? Como é que vai ser?

C: É... na verdade eu perguntei para ela como é que ela tava avaliando... Ela me mostrou uma lista de 35 alunos, com várias atividades que ela fez...daquele livro do estado, mesmo... mas ela queria que a gente pudesse fazer alguma coisa que eles já tenham visto o conceito, mas com experimentação. Inclusive ela gostaria que a gente desse para o primeiro e para o segundo ano. Inclusive ela disse que ela tem um problema muito grande...um pequeno numero de alunos realiza atividade com ela....Como as atividades não são experimentais, em uma turma de 35, 8, 9 alunos fazem a atividade.... e ela falou 
que gostaria de ter essa parte experimental porque ela acha que o pessoal vai realmente participar.

Pesq: 4min21s - E o que vocês estão pensando em fazer? Vão dar a quantidade de movimento, como?

C: 4 min28s - Então... a gente tem um conjunto de atividades que a gente acabou desenvolvendo no curso de metodologia I, e é basicamente o que a gente tinha desenvolvido lá... é mais a parte experimental, alguns experimentos são para realizar em sala de aula e o final, seria, com os alunos, a preparação do foguete.

R: $5 \min 21 \mathrm{~s}$ - A gente ainda não fechou este assunto... A gente ia desenvolver algumas atividades experimentais com eles...ir para a quadra, levar dois skates, coloca uma pessoa em cima de um e outra em cima do outro... discutir a questão do corpo parado, quando os dois empurram...uma análise qualitativa e quantitativa, são coisas que a gente pensou mais ainda não ta fechado.... O limite de 5 aulas é mais porque vai começar a não bater horário nosso com a professora e com a data da entrega do portfólio... A gente começa agora em $1^{\circ}$ de outubro e até o fim de outubro são 5 segundas-feiras... mas a primeira aula ta fechada... a gente vai passar uns vídeos sobre foguetes, coisas do espaço e discutir com eles .

\section{4 ${ }^{\mathrm{a}}$ SUPERVISÃO (03 de Outubro de 2012)}

C: $18 \min 52 \mathrm{~s}$ - Primeiramente, na aula desta semana, a gente começou com um vídeo introdutório, com relação a propulsores, lançamento de foguetes, foguete americano, foguete chinês...e eles até perguntaram...tem foguete no Brasil? A gente comentou sobre os programas espaciais, a professora disse antes para a gente: olha, tem salas que você não vai conseguir, eles não aceitam. Teve até uma outra professora, que era eventual, que foi praticamente expulsa da sala...teve até reunião com os pais dos alunos, tudo. Aí eu já fui assim para esta sala...mas mostramos o vídeo, o pessoal ficou quieto... a professora não acreditava...eles participaram, fizemos bastante perguntas e, no final, passamos o questionário. Explicamos que a proposta era fazer o foguete na ultima aula, a gente ia levar um pronto e os materiais para fazer na hora. Explicamos que a gente ia deixar o portfólio na escola para que se outras turmas em outros anos quisessem fazer, 
era só consultar. Eles adoraram essa história de que o que eles iam fazer serviria para outras turmas... A professora gostou muito, disse que era difícil ver eles assim motivados...tinha um aluno-problema que perguntou o que a gente ia fazer... ele pegou a carteira dele e sentou na frente do computador que ele queria ver o que ia acontecer.

R: 24min49s - Eu dei a mesma aula hoje em dois primeiros anos, mas eu tive um problema...eu não consegui passar o vídeo porque o aparelho não estava funcionando...

Pesq: 24min56s - E aí?

R: 24min58s - Aí...eu dei um jeito.A aula não pode parar! Comentei, desenhei o foguete na lousa, expliquei no quadro. Olha, o pessoal prestou atenção, mesmo. Foi a melhor aula que eu dei. Até que eu não tive problema de disciplina. Tinha um barulhinho ou outro, mas não aquela barulheira. Mas eu já tive experiência em estagio, que a $1^{\mathrm{a}}$ aula normalmente é mais tranqüila, as outras eles pioram, acho que eles vão acostumando.

R: 25min05s - (...) Acho que [a ideia] veio de um professor meu...acho que era de História. Quando a classe começava a ameaçar [fazer bagunça], ele ia para lousa e começava a escrever um monte de coisa para a gente ficar quieto.

$\mathrm{X}: 25 \min 45 \mathrm{~s}-$ Mas essa professora é firme?

R: É! Ela é mais firme.

X: então!!1 nosso professor é uma mãezona...a gente chegou neste ambiente - que os alunos fazem o que querem, conversam a vontade.

X: Ele senta na mesa e não sai dali. Dali mesmo vai falando...do jeito mais várzea possível.

C: 27 min00s - A professora mostrou para a gente um diário com os trabalhos que os alunos entregavam... sempre os mesmos entregavam. Aí a gente pegou nosso questionário e viu que a maioria fez questão de responder...teve até alguns alunos que não deu tempo de fazer na sala e vieram atrás da gente para entregar depois... a 
coordenadora disse que quando a gente fosse fazer as atividades experimentais, para avisar que ela ia tirar foto, por no mural da escola....

C: $28 \min 41 \mathrm{~s}$ - Na próxima aula a gente pensou em levar dois skates e fazer um pouco de atividade experimental, dois alunos sentam no skate, um empurra o outro. Aí a gente ficou pensando... isso vai ser muito curto... então uma proposta era deixar esta parte só para o final. No começo a gente ia pegar o cara mais pesado da turma e por no skate e ai pedir para a menina mais magrinha da turma tentar empurrar..e depois trocar...ai fazer um questionário para ver o que eles estão interpretando daquilo. A professora pediu para a gente abordar bastante nesta aula a questão da quantidade de movimento e impulso.

$\mathrm{X}$ : 30min05s - Olha! Eu acho que você não vai fazer que nem o professor da escola de aplicação, mas toma cuidado porque ele fez essa experiência de por o cara mais pesado, aí disse para ele, rindo: - olha, enquanto você ta aí na boa, sua amiga magrinha vai ser ejetada, praticamente. Chamou o cara de obeso na cara dura!!!

\section{5a SUPERVISÃO (17 de Outubro de 2012)}

Pesq: 0min40s - E aí, o pessoal do skate... fizeram a aula?

R: 1min02s - Olha...vou falar que foi uma aula difícil de dar porque...eu acho que o planejamento da aula não foi bom...a aula... a gente pensou assim...muito na experiência do skate... a gente ia usar dois skates.... mas aí a gente só conseguiu um...a gente teve que improvisar....com a mesma coisa...a mesma ideia...uma pessoa ia ficar em cima do skate, dar um pulinho pro lado e espirrar o skate para o outro lado... aí eu discutia... a velocidade da pessoa era maior ou menor que a do skate? E a massa? Aí eu fiz algumas analogias...e se duas pessoas se empurram? Ai eu tentei trazer isso para o exemplo do skate...teve uma parte também que eu colocava uma pessoa sentada no skate e pedia para outra pessoa dar um empurrão nela... mas a experiência correu muito rápido... eu acho que a discussão não foi muito bem conduzida...o jeito q os conceitos estavam sendo trabalhos não estavam bons...foi um improviso.

Pesq: $2 \min 55 \mathrm{~s}-$ Em que hora da aula você percebeu isso? 
$\mathrm{R}$ : Na $1^{\mathrm{a}}$ aula...a $1^{\mathrm{a}}$ coisa que eu percebi é que a experiência do skate aconteceu muito rápida...

Pesq: $3 \min 08 \mathrm{~s}$ - mas essa noção você teve antes de entrar em aula?

R: Não...foi durante a aula... aí eu tentava trazer outros exemplos que já tinha dito, falei alguma coisa sobre conservação da quantidade de movimento, não que o objetivo da aula era esse, o objetivo era relacionar a velocidade do skate com a massa da pessoa. Como sobrou tempo...eu comecei a falar sobre a quantidade de movimento inicial, final, trazer outros exemplos, como a granada e os estilhaços. Antes a quantidade de movimento de toda a granada era zero, depois... mas foi um improviso...É como se eu estivesse dando o passo seguinte... Depois do skate a gente deveria falar da quantidade de movimento e a sua conservação...E tentei fazer a aula na quadra, mas na hora que a gente desceu, tinha outra turma no pátio jogando ping-pong, aí o barulho era insuportável, não dava nem para eu falar... aí nas outras turmas eu preferi fazer na sala.

Pesq: $6 \min 10$ s - E você vai dar essa aula de novo?

C: 6min16s - Quem vai dar essa aula sou eu. Mas depois de tudo isso, a gente já ta pensando nas modificações que vai fazer...

\section{$6^{\text {a }}$ SUPERVISÃO (24 de Outubro de 2012)}

C: $2 \min 14 \mathrm{~s}$ - Fiz na semana passada aquela aula do skate, mas eu tive que improvisar umas coisinhas a mais, fazer algumas coisinhas a mais, por causa do tempo curto que a gente já tinha falado e não conseguir outro skate para levar...mas eu acabei variando as experiências...uma vez eu colocava pessoa com mais massa, depois com menos massa... e foi tubo bem... a maioria das pessoas participou, tirava dúvidas, responderam o questionário.

R: $4 \min 24 \mathrm{~s}$ - Eu fiz a experiência das bexigas...foi legal, mas como eu tinha feito aquela experiência do skate e foi muito rápida, eu fiquei com medo de acontecer a mesma coisa com a bexiga. Como meu objetivo era falar sobre a lei da conservação da quantidade de movimento, primeiro eu falava sobre a lei, dizia o que a quantidade de 
movimento, dava uns exemplos do tipo, quando um caminhão bate em um carro, fazia umas contas bem simples de quanto era a quantidade inicial e a depois a final, daí eu falava da bexiga antes de fazer a experiência, olha enchia a bexiga e soltei, o que esta acontecendo aqui? A quantidade inicial é zero, depois que eu solto tem que continuar a ser zero...mesmo assim, eu não tenho certeza se eles entenderam a lei...se eles saem da sala de aula, não sei se são capazes de perceber a lei em outras situações... Só que tem conta! Quando tem conta já tem gente que começa a conversar e dormir, tem gente que prefere ficar ouvindo música no celular... Se eu to só falando de como funciona o movimento da bexiga eles participam, mas quando eu to fazendo um conta no quadro, eles não participam tanto... na hora que matematizou, já começa a perder a atenção.

Pesq: 9min36s - e na hora, você tentou alguma coisa ou deixou?

R: 9min40s - Aí eu perguntava alguma coisa que eu tava explicando para essas pessoas que estavam meio distraídas... e aí , meu, o que acontece com a quantidade de movimento do caminhão se ele bater? Certamente eu já vi algum professor meu fazer isso, não lembro quem, mas já vi...dava certo. Em sala de ala é muito difícil conseguir respeito e autoridade sobre os alunos...quando os professores apelam para ameaçar com nota, eu não chego neste ponto, porque eu, no estagio, to algumas aulas e depois vou embora. Acho que quando eu tiver minhas turmas, a conversa vai ser outra. Eu vou chegar na $1^{\mathrm{a}}$ aula, eles não me conhecem e vamos ter que ficar o ano inteiro juntos...acho que o começo tem que ser diferente...no estágio eu já chego dando aula.

C: $10 \min 15 \mathrm{~s}$ - Nesta escola, a professora acabou relatando para a gente... olha, no $2^{\circ}$ colegial, o nível de matemática do pessoal é de $7^{\mathrm{a}}$ série; o que eu passo para eles, tento usar o menor número possível de formulas ( $O$ restante do grupo concorda que esta situação ocorre nos estágios, mesmo na escola de aplicação).

R: $12 \min 15 \mathrm{~s}$ - Aconteceu uma coisa hoje, com matemática, que eu não sei se foi boa ou ruim... Tinha uma hora que eu chegava na conclusão que a quantidade de movimento da bexiga enquanto ela esta voando é igual a do ar que esta saindo ...Quando eu fazia a experiência da bexiga no barbante... eu perguntava o que acontecia com a velocidade? $\mathrm{E}$ eles respondiam que a velocidade do ar diminuía. Eles relacionavam tranquilamente massa e velocidade. 


\section{$7^{a}$ SUPERVISÃO (31 de Outubro de 2012)}

Pesq: Se tivesse q fazer alguma coisa diferente...

C: $18 \min 14 \mathrm{~s}$ - Ah, eu mudaria a atividade. Aquela atividade do skate não deu muito certo, mas o vídeo foi bem proveitoso, a parte da bexiga com o canudo também, teve bastante participação...

$\mathrm{R}: 18 \mathrm{~min} 57 \mathrm{~s}$ - Acho que precisava de mais tempo para fazer o projeto, acho que alguns conceitos ali ficaram frágeis...

C: $19 \min 10 \mathrm{~s}$ - E a professora pediu para a gente não dar a abordagem matemática, a gente não utilizou praticamente nada de matemática...talvez se a gente tivesse mais tempo para negociar, dar umas coisas mais simples...quando a gente trazia a questão, era sem conta...as vezes a gente trazia questão de outro experimento...eles tinham que imaginar como seria... a gente acabou não envolvendo a matemática, mas nas respostas a gente pedia para o pessoal relacionar esse negócio, massa e velocidade...

\section{$8^{\text {a }}$ SUPERVISÃO (14 de Novembro de 2012)}

C: $12 \min 23 \mathrm{~s}$ - A gente descobriu que não dava para montar o foguete e lançar na mesma aula... descobrimos no dia que a gente ia levar o foguete para a sala... aí na primeira aula, eu cheguei, expliquei como montava, trouxe o material, 16 garrafas pet, dava para quatro grupos, mas aí faltou garrafa... tivemos que fazer em três salas, só, o pessoal ficou muito empolgado, até aquele pessoal que não queria fazer nada, fez... a professora gostou bastante... até os desafetos da professora participaram...a coordenadora gostou bastante, tirou foto... aí a gente já tava percebendo que não ia dar para lançar... aí dissemos que semana que vem a gente voltava para lançar; estavam todos empolgados... na outra semana a gente voltou, testamos a bomba no fim de semana, funcionou, o pessoal adorou, tinha o professor que parava de dar aula para ver o lançamento... a professora disse - fala para o pessoal mandar estagiário para a gente aqui, é isso que os alunos querem... eu achei que a $1^{\mathrm{a}}, 4^{\mathrm{a}}$ e $5^{\mathrm{a}}$ aula foram muito boas, o pessoal realmente aproveitou, mas acho que as outras duas, eu mudaria hoje a proposta...aquela do skate... eu proporia outra atividade, porque eu achei que o resultado 
não foi tão bom, a discussão não foi tão legal como as outras...uma coisa também que a gente teve sorte de pegar uma professora que realmente apoiou a gente...o que vocês precisarem.... quando faltou a garrafa, ela foi ate o boteco comprar mais garrafa, a coordenadora - o que você precisar você pede, então foi um pessoal que ajudou...achei que foi bem valido o estagio, deu para perceber bastante a deficiência que o pessoal tem, ate mesmo uma carência dos alunos eu reparei que este trabalho trouxe os alunos muito mais perto da professora, pena que foi 6 meses... Pelo lançamento que eu fiz com o pessoal, dava $\mathrm{p}$ ver que eles estavam entendendo...sem matemática...mas sabiam... quando chegou uma professora que queria saber como funcionava, eu pedi para o aluno explicar para ela e ele conseguiu, explicou direitinho... 
ESTAGIÁRIOS A, L e W (GRUPO II)

TRANSCRIÇÃO DAS SUPERVISÕES - 2012 (17h40min - 18h30min)

$1^{\text {a }}$ SUPERVISÃO (29 DE AGOSTO DE 2012)

(GRUPO NÃO COMPARECEU NA $1^{\mathrm{a}}$ REUNIÃO DE SUPERVISÃO)

\section{$2^{\mathrm{a}}$ SUPERVISÃO (12 de Setembro de 2012)}

A: 0min48s - (Exp. Docente) Não, minha experiência é só nos estágios da faculdade...

Pesq: Aula particular?

A: Não.

L: 0min58s - Dei aula particular por seis meses...depois disso eu parei... só dei aula em escola nos estágios.

W: 1min40s - Experiência só nos estágios aqui na faculdade de educação.

Pesq: $1 \min 57 \mathrm{~s}$ - Bom, para semana que vem vocês tem que preparar a questão de pesquisa de vocês. Vamos ver o que vocês já tem...

A: 2 min00s - A gente vai fazer sobre avaliação... quais métodos de avaliação permitem aos alunos expor e debater melhor suas ideias, proporcionando discussões.

W: $2 \min 30 \mathrm{~s}$ - A gente vai trabalhar com debates, discussões, proposição de problemas abertos...

A: $2 \min 53 \mathrm{~s}$ - A gente ia tentar levar eles no planetário... no Ibirapuera, e ai, quando a gente voltar desta visita, a gente vê o que eles aprenderam lá...ver se neste ambiente aberto eles aprenderam alguma coisa, fazer uma discussão... A gente quer fazer um jogo, também, que trabalhe os conceitos básicos de astronomia... a gente também quer fazer um júri... Mas a gente vai fazer em duas partes... a primeira parte são duas aulas com as leis de Newton, porque o professor pediu...

L: $3 \min 54 \mathrm{~s}$ - Na $3^{\mathrm{a}}$ aula a gente vai dar uma prova escrita para eles, mas é o critério do professor, ele pediu para a gente fazer esta avaliação e liberou o tema para as outras aulas... aí a gente escolheu astronomia. 
$\mathrm{W}: 4 \min 22 \mathrm{~s}$ - A gente já tem algumas atividades e dentro delas a gente vai ver qual conceito de astronomia a gente vai trabalhar.

A: $4 \min 55 \mathrm{~s}$ - A primeira aula a gente só vai explicar, então não tem avaliação. $\mathrm{Na}$ segunda a gente vai passar algum experimento para eles, aí a gente pede um relatório, aí depois vem a prova, aí na outra semana a gente começa astronomia. A gente quer comparar esta prova com as avaliações que a gente vai fazer em astronomia. Essa das leis de Newton, o professor já deu uma prova... foi totalmente de conta. A gente queria fazer alguma coisa diferente.

Pesq: $5 \min 40$ s - Vocês pretendem gravar estas aulas?

A: A gente quer gravar. Já começa esta sexta.

Pesq: 6min10s - É que como vocês vão falar sobre avaliação, não é só papel...às vezes com a gravação você consegue fazer a leitura de sala, a participação...mas como serão as aulas de vocês?

W: 6min32s - uma aula com conceitos básicos, falar sobre medidas em astronomia; na segunda, a gente vai mandar eles fazerem um planisfério, a terceira aula a gente pensou em trabalhar vida extraterrestre e elaborar uma síntese, em cartazes...Nesta parte de vida extraterrestre a gente pensou em trazer algum artigo tipo Veja, Extra para eles discutirem... depois vem o jogo de astronomia.

Pesq: $8 \min 37 \mathrm{~s}$ - e já pensaram como vai ser este $\mathrm{j}$ ?

W: Na turma de prática, o pessoal já elaborou um jogo do tipo Uno, com cartas... aí na outra aula a gente vai no planetário...mas a gente ainda não falou com a escola, então vamos ver se a gente consegue levar...

A: $20 \min 05 \mathrm{~s}$ - A gente já observou a primeira aula, tem 40 alunos, três prestam atenção...

L: $20 \min 49 \mathrm{~s}-\mathrm{O}$ professor entrou na sala, escreveu a prova na lousa... era de vetores... exercícios imediatos...mas ele recolheu, já corrigiu e falou as notas... tinha uns 27 zeros.

A: 21min51s - O professor foi aluno da Maria Lúcia, se formou há pouco tempo, mas você olha para ele... parece que ele já ta muito cansado de dar aula, acabado. A gente 
chegou e ele falou - me fala o que vocês querem fazer, o que tiver que aplicar eu aplico... sabe... ele não tem um plano de aula.

L: $23 \min 05 \mathrm{~s}$ - O problema maior para mim é que a gente não conseguiu ver ainda uma aula certa do professor. Quando a gente foi lá, ele demorou 10min para começar a aula, ficou sentado em cima da mesa do professor 20min é só falando das leis de Newton, não escreveu nada no quadro...ele perguntava e já respondia, nem deixava os caras irem falando.

Pesq: 23min30s - Então.. mas é complicado você comparar a prova de leis de Newton que ele vai dar com as suas avaliações de Astronomia...

A: $23 \min 40$ s - Mas a gente não vai comparar nada dele. A gente vai dar mais duas aulas de leis de Newton e dar a nossa avaliação... eu senti que o professor queria empurrar até a própria lei de Newton para a gente dar inteira...Um amigo nosso contou que foi fazer estágio com este professor, e ele deixava meu amigo na sala e ia embora... depois voltava, elogiava a aula que ele nem tinha visto e mandava voltar sempre.

W: 27min26s - O professor não ta nem aí com a turma...

L: 27min48s - No primeiro semestre, na escola de aplicação, os professores eram muito mais engajados, tinha problema de disciplina, mas pelo menos ele chamava a atenção... esse aí , não. A primeira aula que a gente acompanhou foi uma bagunça geral, e ele tinha dito que essa era a turma boa, imagina a ruim... As carteiras não tinham nenhuma organização, cada aluno virado para um lado. Tinha duas alunas encostadas na parede...era como se elas nem tivessem ali... Quando o professor falou que acabou a aula, elas ficaram do mesmo jeito, tinha sido irrelevante para elas... a avaliação dele era totalmente tradicional... não tinha motivação nenhuma...

\section{$3^{\text {a }}$ SUPERVISÃO (26 de Setembro de 2012)}

A: $11 \min 17 \mathrm{~s}$ - a gente já deu duas aulas... a primeira foi de Leis de Newton, mas como a aula foi muito curta, a gente só conseguiu dar uma das leis de Newton...o professor já tinha trabalhado com eles... foi legal, deu certo... Na verdade, a terceira lei que ficou com a gente, porque o professor já tinha dado a $1^{\mathrm{a}}$ e a $2^{\mathrm{a}}$, mas a gente fez uma revisão das duas antes de explicar a $3^{\mathrm{a}} \ldots$ a gente começou dando uma tirinhas sobre inércia para eles lerem e, no final a gente pediu um questionário que eles entregaram para a gente... 
no começo a gente deu as tirinhas, explicou, deu exemplos, na $2^{\mathrm{a}}$ lei, a gente passou a fórmula na lousa, antes a gente tinha explicado... ai o pessoal reclamou - fórmula, não! - mas a gente disse, vamos tentar, ai fomos indo e n o final recolhemos a avaliação... a gente não leu todas ainda, mas a gente pegou e viu que eles não entenderam!? Parecia que na aula tinha sido legal, mas depois a gente viu que tinha uns poucos muito bons, a maioria copiou, entregou em branco...

Pesq: 14min32s - Mas tem que ver estes resultados...é um questionário inicial...para ver como vocês vão trabalhar astronomia.

L: 14min52s - Não... mas a gente já começou astronomia, mesmo sem os resultados, porque mudou o horário e a gente teve que começar...

Pesq: $15 \mathrm{~min} 17 \mathrm{~s}$ - e astronomia vocês tão falando do que?

A: $15 \min 34 \mathrm{~s}$ - então, foi muita loucura. Porque a gente ficou sabendo na $4^{\mathrm{a}}$ que ia dar aula na segunda, e como a gente não consegue se falar direito foi uma loucura.

L: 1 min58s - Então... primeiro a gente começou com uma discussão básica sobre o que eles achavam que era astronomia, nomes dos planetas, dimensões e distâncias interplanetárias e solar... agente pensou em falar agora a Lua, da Terra e do Sol... fases da Lua

A: $16 \min 34 \mathrm{~s}$ - porque é algo que eles tem mais contato...todo mundo olha para a Lua e vê... e eles já tinham perguntado para a gente...

L: $17 \min 31 \mathrm{~s}$ - È que a gente perguntava o que eles achavam que estudava a Astronomia, mas a sala zoava com todo mundo que respondia: Ah, o Universo! Que Universo, o que? Ah, as Estrelas! Ah, que estrelas o que?

W: $17 \min 43 \mathrm{~s}$ - Começa a entrada, eles acalmam...mas é só a gente dar risada que a gente perde o controle total da sala...

L: $18 \min 07 \mathrm{~s}$ - Na primeira aula a gente chegou $5 \mathrm{~min}$ atrasados. Quando a gente entrou o professor já tava passando uma prova na lousa. Quando viu a gente, parou tudo e mandou a gente começar. Quer dizer... os alunos estavam totalmente focados em outra coisa... tanto é que a gente não conseguiu falar de tudo que a gente queria... falamos só das fases da Lua. 
A: $18 \min 47 \mathrm{~s}$ - Então, na primeira turma não deu nada certo. A gente chegou atrasado... para explicar as fases da Lua a gente levou o globo com um cabo de madeira no meio e duas bolinhas para representar o Sol e a Lua e fomos chamando eles - quem vai ser o Sol? Quem vai ser a Lua? Só que isso deu errado também, porque a gente ficou trocando de aluno...Nessa de escolher outros alunos, a gente perde muito tempo... $\mathrm{Na}$ segunda aula a gente já não fez isso.

W: 20min10s A primeira turma era mais tímida, mais quita, mas não prestava atenção. $\mathrm{Na}$ segunda turma, a gente pediu para dividirem em grupos, ficou 5 de um lado e 20 do outro. Os cinco não prestaram atenção em nada, mas os vinte eram barulhentos, mas prestaram atenção, do jeito deles. Mas aí eu perguntei a hora que ia ser tal fase da Lua e a menina lá no fundo perguntou: Mas que horas nasce o Sol? E eu já tinha falado isso umas mil vezes na aula, foi o começo da aula.

L: $21 \min 22 \mathrm{~s}$ - Se bem que eu to pensando uma coisa agora....a nossa Terra era muito grande...a Lua era menor que a Terra, mas a Terra era maior que o Sol???

A: $21 \min 39 \mathrm{~s}$ - Agora na próxima aula a gente vai levar um jogo - o super trunfo...só que a gente não quer só dar o jogo... a gente quer falar alguma coisa com eles antes.

\section{$4^{\mathrm{a}}$ SUPERVISÃO (03 de Outubro de 2012)}

L: 7min08s - A gente deu a terceira aula, levamos o Super trunfo. Primeiro a gente começou fazendo uma revisão da aula da semana passada...mas assim que a gente escreveu na lousa, podia ver que eles odiaram...

A: $7 \min 44 \mathrm{~s}$ - A gente na verdade queria dar uma avaliação do que a gente deu na ultima aula...mas quando a gente começou a perguntar a gente viu que eles estavam chutando, não tinha nada a ver. Falavam qualquer coisa - lua nova, cheia!! Então a gente parou e tentou explicar bem rapidamente de novo, de outra forma...aí parece que ficou um pouco mais claro, mas não sei não... aí a gente começou o super trunfo - deu muito certo. Uma pessoa que a tinha aplicado já tinha dito para a gente - dá as cartas, mas não fica ali parado, circula entre os grupos, senão eles só jogam e esquecem do conteúdo.

Pesq: $9 \min 52 s$ - Então, o que eles acharam? 
A: 9min55s - Amaram! Todo mundo participou.

L: 10min06s - Eu e a A testamos e demoramos dez minutos para jogar. Só que a gente deu na sala e um grupo conseguiu acabar em...sei lá...1minuot e meio... aí a gente ficou meio sem saber o que fazer...teve que pedir para eles jogarem de novo. Não dava para deixar eles sem fazer nada, senão vira bagunça. Teve gente que demorou muito e gente que demorou pouco. A gente tinha até pensado em fazer um campeonato na ala, mas a gente achava que o tempo não ia dar... Aí na segunda turma, antes de começarem a jogar, a gente pediu para eles separarem as cartas em categorias, que ia dar mais certo, antes de começar.

A: $12 \min 14 \mathrm{~s}-\mathrm{O}$ pessoal todo participou, foi bem legal. Mas tinha duas meninas, na segunda turma, que ficavam bem na frente e gritavam todas as respostas, não dava chance para os outros responderem...e respondiam qualquer coisa...queriam chamar a atenção. Aí no final da aula elas chegaram e disseram: olha a gente participou bastante! Vamos ter dez em participação...

Pesq: $12 \min 50 \mathrm{~s}$ - mas vocês avisaram que ia ter nota de participação?

A: $12 \min 55 \mathrm{~s}$ - a gente disse que ia avaliar tudo, inclusive participação. No final da aula a gente pediu para eles fazerem um relato sobre a aula... a gente não quis deixar para casa, porque da outra vez eles copiaram muito de internet, deles próprios, outros não faziam, então a gente pediu na hora, para poder ver o que eles faziam mesmo. O ruim é que a gente tem que falar muito alto, acaba a aula não tem mais voz. Essas duas turmas aí...

L: 17min30s - Eu já tinha feito estágio nesta escola com outra professora... ela era bem tradicional, o pessoal ficava quieto na aula dela.... não sei se prestavam atenção, mas não tinha barulho.

A: 17 min $57 \mathrm{~s}$ - Ah, não sei... eles dizem que tem esta questão da indisciplina... Eu não acho...tudo bem, tem barulho, atrapalha, mas quando você olha a filmagem, você vê que eles estão falando sobre a matéria, não tem conversa paralela. Quando o L começa a falar, por exemplo, eles param de falar... 


\section{5a SUPERVISÃO (17 de Outubro de 2012)}

A: $18 \min 27 \mathrm{~s}$ - Então, a gente analisou a $1^{\text {a }}$ avaliação, aquela sobre inércia. A gente pediu um resumo sobre esta lei, mas $90 \%$ copiaram o que o professor tinha passado na lousa. Alguns enviaram conceitos errados - a $2^{\mathrm{a}}$ lei de Newton para eles era a lei do Peso...eles erram totalmente na hora de explicar... na $3^{\text {a }}$ questão, que era para usar a fórmula, a maioria acertou, mas graças à gente, porque como a gente sabia que eles não gostavam de matemática, a gente enfatizou bastante esta parte

\section{$7^{\text {a }}$ SUPERVISÃO (31 de Outubro de 2012)}

A: $5 \min 56 \mathrm{~s}$ - A gente deu 3 aulas esta semana... A gente propôs um júri aberto...quais as características que precisaria ter para se ter vida fora da Terra...primeiro a gente conversou com eles sobre as atividades, porque quando a gente mandava para casa ninguém fazia... aí a gente propôs o problema, eles começaram a conversar...se era vida inteligente, se não era... ai eles fizeram...mas a reposta deles foi bem objetiva, bem curta...água, energia nuclear...Essa parte foi meio legal...porque metade da direita prestou atenção na gente, mas a metade da esquerda, nada...Na outra turma também... foi metade ótima...metade péssima...paciência... não dá para parar no meio, né? Demorou 20minutos para eles ficarem quietos... aí a gente falou da gravação...que a gente ia gravar o rosto de cada um...

L: 9min31s - Nossa... eu já tinha feito isso quando era aluno...tentar fazer movimento da sala para derrubar um professor...mas não achei que era assim...aí a sala inteira já tava gritando que não podia, que a gente não podia fazer isso...virou um tumulto....minha cabeça começou a explodir

A: $9 \min 59 \mathrm{~s}-\ldots$ aí eu falei... ta bom, ta todo mundo com zero! Ah... eu sou muito boazinha, mas não deu...pelo menos eu consegui controlar a sala de novo.

L: 10min55s - Aí eu também disse que eles iam ser a única sala que não ia fazer a atividade.. eu lembro que quando meu professor fazia isso, dava certo... aí a aluna veio me perguntar: mas para quem você mais da aula? Ai eu disse: dou aula para os dois 1os, para o $2^{\circ}$, para o $3^{\circ}$, inventei tudo, para fazer a maior pressão... mas foi um tumulto... já para entregar os textos foi mais da metade da aula, depois este tumulto... 
Pesq: $14 \min 43 \mathrm{~s}$ - Se vocês tivessem que abordar este conteúdo novamente...mudariam algo?

A: 14min58s - Primeiro, a gente não escolheria aquela escola...

L: $15 \min 09 \mathrm{~s}$ - Sinceramente, quando eu sai da $1^{\mathrm{a}}$ aula, aquela do texto, eu já sai assim ó... (decepção).

W: $15 \min 15 \mathrm{~s}$ - Não tem apoio do professor

A: $15 \min 30$ s - Semana passada a gente não foi e ele deu uma prova para os alunos. A aula dele é sempre uma prova, então os meninos estão acostumados com isso...o problema é que a gente ta exigindo algo de alguém que nunca viu isso,não esta acostumado a este tipo de atividade... mas eu tentaria mudar o meu comportamento, tentaria colocar mais ordem na sala logo no começo...Essa parte da Física....Astrofísica, Astronomia...sei lá... exige maio concentração do aluno.

L: 16min25s - Não dar exemplo com os alunos, porque demora muito... a gente tem que basicamente moldar a aula em torno da fala deles, porque eles falam muito, muito barulho.

Pesq: Se tivesse q fazer alguma coisa diferente...

\section{$8^{\text {a }}$ SUPERVISÃO (14 de Novembro de 2012)}

A: $5 \min 37 \mathrm{~s}$ - A gente pediu para eles fazerem uns cartazes como avaliação de tudo o que agente deu de astronomia...Não ficou bom...puseram o título, desenharam o Sol e a Terra e pronto. Ficou muita cópia... O pessoal não tava nem aí.. para fazer o círculo (da Terra) foi a aula inteira. Mas vocês não aprenderam nada...eles estavam muito quietos... Ah, mas e o planeta que a gente mora? Ah! o Brasil! Eu disse - Nossa!!!

L: $8 \min 40$ s - Eles lembravam...a eles falaram de planetas... entraram no Google em planetas e copiaram tudo...

Pesq: $9 \min 20$ s $-\mathrm{E}$ a outra sala? 
L: $9 \min 27 \mathrm{~s}$ - A outra sala eu fiquei surpreso com a quantidade de coisas que eles copiaram que eu tinha passado na lousa... Copiaram tudo... Pediram para pegar livro na biblioteca...

Pesq: 11min05s - E no geral, como vocês julgam o estágio?

L: $11 \min 18 \mathrm{~s}$ - Primeiro acho que foi o estágio mais trabalhoso que a gente teve que fazer... eu ainda acho que as salas foram um pouco decepcionantes...

A: $11 \min 35 \mathrm{~s}$ - Eu não acho que seja o estágio onde eu mais aprendi...eu acho que aprendi muito mais na escola de aplicação...tinha mais coisas para eu aprender com o professor, com os alunos, com o jeito deles, sei lá...acho que esse foi mais desgastante...

L: $12 \min 00 \mathrm{~s}$ - Esse a gente teve mais responsabilidade, tinha que fechar as notas deles.. a gente estava mais sozinho...

L: $24 \min 13 \mathrm{~s}$ - Então...quando eles (outro grupo) falavam do apoio do professor... eu lembro que a gente não teve isso... na última aula eu fui ate a mesa dele e tinha uma folha com vinte questões sobre Leis de Newton, tinha de tudo, gráfico, função horária... aí ele disse...tá vendo, é a recuperação deles, ninguém vai passar... Ou seja, ele não deu nada daquilo que a gente tinha dado...

A: $24 \min 27 \mathrm{~s}$ - Ou seja, ele não deu o menor valor para gente... e pegando nossas avaliações de leis de Newton dava para ver que o professor tinha ensinado errado para eles...eles falavam da segunda lei como sendo a lei dom Peso...

L: 26min36s - Para foi muito desgastante porque alem de não ter apoio dos alunos, não tinha apoio do professor... eles só faziam se valesse nota.

A: $27 \min 10$ s - Eu até imaginei... a gente vai chegar na sala pedindo os cartazes...eu entrei na sala e tive que dizer - pessoal, a gente ia dar uma prova individual para vocês, mas a gente resolveu dar uma coisa em grupo, mas só assim, mesmo...se eu não tivesse falado isso, acho que eles não iam fazer. 


\section{APÊNDICE 2 - TRASNCRIÇÃO DAS ENTREVISTAS FINAIS}

\section{1 - ESTAGIÁRIO R}

Pesq: Para efeito de registro...fala seu nome completo e idade...

R: R ..., 26 anos

Pesq: Tá... sua experiência profissional...

R: Só os estágios da faculdade... da licenciatura, e da prática de ensino, POEB, Psicologia da Educação, didática...

Pesq: Todos você freqüentou em sala de aula?

R: É... mas a maioria foi observação, né? Acho que o único que eu tive que dar aula foi o metodologia I, semestre passado e o de metodologia II... há... e na prática de ensino eu também tive que dar aula.

Pesq: Você considera a escola que você estagiou como tradicional ou alternativa?

R: Ah, tradicional... Não tem nada de muito diferente...eu tive a impressão que era uma escola muito organizada, mas só isso.

Pesq: Como foi a recepção dos professores, coordenação, direção e alunos com a sua presença?

R: Eu já tinha feito estágio lá no ano semestre passado, então eu já conhecia uma coordenadora. Então eu já cheguei falando que queria falar com ela...falei com ela... ela disse que tudo bem, que ia conversar com a professora de física... então foi fácil neste sentido...a professora também foi muito receptiva...ela gostou muito da ideia de ter estagiário, ficou muito empolgada, ela deu muito apoio... inclusive, dentro da sala de 
aula ela dava apoio...ela conseguia manter os alunos disciplinados...se fizessem bagunça, ela chamava a atenção e eles obedeciam... Agora os alunos foi assim... no começo foi bastante interessante, eles estavam interessados e tal, mas depois foi ficando menos...acho que tem a ver com a formalização da física, parece que vai ficando carregado, o pessoal vai ficando desmotivado e também acho que como eles também já me conhecem e fica uma coisa mais intima, eles ficam mais soltos. No começo eles ficam mais travados... mas a recepção foi boa.

Pesq: Você acha que o estágio realizado contribuiu para sua formação como professor?

R: Contribuiu...acho onde mais contribuiu foi porque eu dei mais aulas sozinho, antes eu dava aula com alguém, com um grupo e desta vez eu e o $\mathrm{C}$ tivemos que nos dividir. Deu para sentir mais a sala de aula...

Pesq: Qual era o objetivo inicial do projeto?

R: O projeto era sobre conservação do momento e a gente queria apresentar para mostrar no fim a construção de um foguete...o objetivo era verificar como a construção do foguete motivaria os alunos...

Pesq: E você considera que alcançou este objetivo?

R: Não...responder isso não... acho que faltou alguns elementos para avaliar esta motivação...mesmo hoje eu não saberia avaliar esta motivação...Existem outras coisas que motivam...é difícil saber o que realmente está motivando eles. Na primeira aula estava clara a motivação deles na questão da construção do foguete, na propulsão, mas depois eles foram ficando desinteressados.

Pesq: E por que você escolheu este conteúdo? 
$\mathrm{R}$ : Na verdade, no semestre passado, eu e o $\mathrm{C}$ fizemos um projeto de mini-curso para a metodologia I...a nossa ideia era essa...fazer um mini-curso sobre a Física da propulsão...e a gente ia construir um foguete...essa ideia veio daí...da metodologia I...mas quem deu mesmo essa ideia foi o $\mathrm{C}$, de uma aluna que ele dava aula particular e tinha que construir este foguete...

Pesq: Tem alguma particularidade que o aluno tenha que saber para ensinar a quantidade de movimento?

R: Acho que não... mesmo a matemática...não é pré-requisito. Qual é a matemática necessária? Uma soma, uma multiplicação...Depois do que a gente aprendeu na matematização do pensamento físico, isso não deve ser pré-requisito.

Pesq: Que estratégias vocês utilizaram para abordar o conteúdo?

R: A gente primeiro fez uma problematização usando vídeos, mostrando os vídeos de foguetes, perguntou como é que funcionava isso. Na segunda e terceira aula fiemos algumas experiências para simular a quantidade de movimento e a construção do foguete no fim. Mas eu acho que a construção do foguete não pareceu uma aula, pareceu meio avulsa...no dia que você está construindo você ta dando aula? Ta revisando tudo o que eles já viram? Tá brincando! Tá fazendo uma brincadeira a mais...

Pesq: E de onde veio as ideias para abordar o tema com essa sequencia de estratégias?

R: eu tinha o curso mais ou menos preparado da metodologia I...eu tenho essa ideia...é sempre bom ter um ciclo e pequenos ciclos para dar o conteúdo...você problematiza, ai você começa a dar as condições para o aluno entender e aí você parte para a próxima problematização, até que uma hora...você tinha uma problematização grande e vai diminuindo para o particular. Para mim parece fácil montar uma problematização com 
uma experiência..tem a coisa do foguete como todo e t em a problematizacao dentro de cada aula.

Pesq: Esses ciclos...você pegou isso de algum texto?

R: Não, não...é ideia minha...com o professor de metodologia I, a gente teve algumas atividades e eu comecei a pensar nisso. Mostrei para ele e perguntei se agente podia usar isso...ele disse que sim.

Pesq: Onde você buscou as informações para a montagem do projeto?

$\mathrm{R}$ : A gente foi atrás de como construir o foguete...o $\mathrm{C}$ conseguiu o trabalho que era sobre a quantidade de movimento em sala de aula, mas eu não li.

Pesq: Como era a relação entre alunos e professores:

R: Parecia que era uma escola ate com certa organização, dava para ver uma certa bagunça...teve um dia que tinha uma correria no corredor e a diretora tava correndo atrás dos alunos, mas foi um caso isolado...existe uma autoridade da diretora, todos respeitam ela e a professora também tinha sobre a sala de aula.

Pesq: O que você achou da reação dos alunos durante o estágio?

R: Eu não tenho certeza se eles se apropriaram da quantidade de movimento...a gente passou um questionário...teve turma que acertou muito, que parecia que aprenderam, mas teve turma que não...tinha diferença grande...esta turma que não aprendeu parecia maior, e as que acertaram, eu achei que tinham colado, as respostas muito parecidas...acho que para entender a quantidade de movimento tinha que ter mais aulas.

Pesq: imprevistos... 
R: O projeto tinha 4 aulas e a $4^{\mathrm{a}}$ era a construção e o lançamento do foguete...o $\mathrm{C}$ teve que decidir sozinho e o $\mathrm{C}$ optou só por construir e a gente teve que voltar depois para lançar... tinha que lançar, né?

Pesq: E se você aplicasse de novo?

R: Tinha uma atividade dos skates que não rendeu muita discussão, foi muito rápida...a ideia era falar sobre..colocava uma leve e outra pesada para se empurrar...mostrar que ia mais devagar...o problema é que esta atividade pareceu muito obvia para eles, não rendeu discussão, foi rápida demais para eles...talvez eu colocasse dois bloquinhos com molas..que nem na faculdade. É a mesma coisa, mas fica mais ilustrativo, porque quando eles se empurram, não dá para garantir que a força do empurrão era sempre igual.

Pesq: E em conversa com outro professor?

R: Isso não aconteceria na realidade...eu diria para gastar mais tempo com os alunos que tem mais dificuldade...muita gente dá atenção para quem tem mais facilidade.

Pesq: E como você faria isso?

R: Você tá na sala de aula, sente que a turma ta acompanhando, mas você percebe um grupo que não ta falando nada... você tem que propor um atividade para esses que estão entendendo e atender aqueles que não estão entendendo.

Pesq: E o trabalho com o restante do grupo?

R: Foi tudo meio fragmentado...a gente não dava aula no mesmo dia, a apresentação e a montagem foi feita toda separada...é mais difícil, não é tão democrático...a discussão fica mais difícil. 
Pesq: O que você considera importante um professor de Física saber para ensinar Física?

R: Eu tenho uma ideia de conjunto...tem que sabre estas estratégias pedagógicas, como tratar o aluno, como tratar a sala como um todo...tem que saber articular um assunto ali na hora com alguma coisa do cotidiano deles, muito rápido...porque você consegue segurar o interesse deles...eu já notei isso... acho que a melhor forma de combater a indisciplina é essa...manter o aluno interessado...fazer com que os alunos associem a aula de física a uma experiência boa, que eles querem participar...eu acho que Física hard é um pouco importante, porque quando você sabe a física hard, você consegue explicar com clareza algumas ideias fundamentais, você transmite confiança para o aluno...tem que saber física hard. A gente quando entra na Física, a gente tem ideias obvias, mas eles não tem...quando você vê $1 \mathrm{~km} / \mathrm{h}$, você sabe que ele anda $1 \mathrm{~km}$ em $1 \mathrm{~h}$, mas eles não vêem isso...

Pesq: E o que você achou da supervisão?

R: Olha, eu tenho certeza absoluta que esta supervisão não foi só para pesquisa. A professora já deve ter tido muitos problemas de alunos que chegam no final do curso com estágio atrapalhado...então a supervisão é a solução... Mas para mim ajudou...a gente tinha algumas duvidas, será que a gente pode aplicar isso ou aquilo? Em setembro eu tirei essas duvidas na supervisão...é importante ouvir a opinião de alguém. Ajuda sem a gente perceber. 


\section{2- ESTAGIÁRIO C}

Pesq: Para registro...nome, idade e experiência docente.

C: C ......, 32 anos, dou aula particular há 5 anos.

Pesq: Como foi a recepção dos professores, coordenadores...quando você chegou na escola?

C: A recepção foi muito boa, o $\mathrm{R}$ já tinha feito estagio lá, então facilitou, mas mesmo comigo, fui muito bem recebido...a professora, a coordenadora vinham sempre falar comigo, ver se eu precisava de alguma coisa...

Pesq: Como você acha que o estagio contribuiu na sua formação?

C: Ele me ajudou a perceber que um numero grande de alunos é difícil ter um resultado bom...se a gente tivesse turmas reduzidas, seria melhor... outra coisa que eu percebi é que a experimentação é fundamental para motivar os alunos, deu para ver isso no estágio.

Pesq: Qual era seu objetivo inicial no estágio?

C: Inicialmente era verificar se a Física experimental era tão motivadora para o ensino de física. Eu considero que atingi este objetivo, pois nas atividades finais o pessoal participou bastante, eu considero que houve uma construção de conhecimento.

Pesq: Qual era o conteúdo que você trabalhou no estágio?

C: Conservação da quantidade de movimento...a gente tinha desenvolvido este projeto em metodologia I, mas não tinha aplicado...aí a gente teve a chance de aplicar o projeto. 
Pesq: Tinha alguma particularidade que o aluno precisava saber para aprender este conteúdo?

C: Olha...um pré-requisito seria que o aluno soubesse uma parte inicial de mecânica, movimento uniforme, facilitaria bastante...

Pesq: Quais estratégias você utilizou?

C: a gente viu que só prática experimental não seria suficiente...então a gente usou vídeos, resolução de algumas questões, para ver se eles estavam aprendendo...

Pesq: Porque você achou que a prática experimental não era suficiente?

C: Para realizar a prática experimental é preciso uma certa experiência e um negocio muito bem elaborado. Teve atividade que a gente montou e previu - vai acontecer isso. Ai, na pratica foi muito rápida, e a gente não tinha ideia do que fazer depois.

Pesq: e de onde veio a ideia?

C: Olha... um dos motivos de eu fazer Física é a parte experimental. Eu tenho um primo que também é Físico e me levou para conhecer os laboratórios...isso foi muito motivador...e se me motivou pode motivar outras pessoas também...esse foi um dos pontos principais para esta questão experimental.

Pesq: Mas e o foguete?

C: Essa ideia da propulsão...no semestre passado, uma aluna minha que fazia aula particular comigo pediu ajuda para desenvolver este foguete, e ela falou que o pessoal da escola ficou muito motivado com isso, um ia espionar o foguete do outro, ficavam pensando na aerodinâmica...parecia bem legal...aí eu fui pesquisar para ajudá-la. 
Pesq: E de onde você tirou as informações para realização do projeto?

C: A gente usou textos acadêmicos, vídeos da construção do foguete, inclusive isso ajudou a gente a testar, porque não deu certo a primeira vez que a gente montou...

Pesq: E o ambiente na escola?

C: No geral, a gente ouviu muita reclamação dos professores de certos alunos e, quando a gente foi dar as aulas experimentais, aqueles alunos que lês reclamavam, mostravam um certo interesse. Eu não conhecia a escola...foi diferente, mas a gente não considerou este contexto no nosso planejamento.

Pesq: e a reação dos alunos?

C: Olha, logo na primeira aula, aqueles alunos que eram tido como problemas participaram muito...a gente pode falar que 70 ou $80 \%$ da turma participou do nosso projeto.

Pesq: E teve algum imprevisto?

C? O que aconteceu é que a gente achou que ia dar tempo de construir e lançar o foguete no mesmo dia, mas aí a gente percebeu que não ia dar... a gente ia ter que vir um dia a mais para lançar o foguete.

Pesq: E se você aplicasse de novo?

C: Primeiro, tem algumas experiências que eu mudaria.. a dos skates...a gente só tinha um skate...então o planejamento antecipado é fundamental, ter todos os materiais prontos com antecedência.

Pesq: e se você fosse comentar esta experiência com outro professor? 
C: Eu diria que é válido o estágio, tem que var outras realidades. Como eu dou aula particular, eu tenho outra realidade, não estou acostumado com a escola pública...mesmo ouvindo vários comentários ruins, foi bom, porque eu não tive este préconceito de que não vai dar certo...eu fui querendo fazer algo diferente...tem gente que não vai querer saber...mas a maioria vai.

Pesq: O que você acha que um professor de Física tem que saber para ensinar Física?

C: Eu acho que , primeiramente tem que saber Física...toda esta parte que a gente viu em metodologia II - os conhecimentos metodológicos, como o aluno aprende, o professor que ter certo tato para lidar com certos alunos, tem que entender todos os lados.

Pesq: E a supervisão?

$\mathrm{C}: \mathrm{Eu}$ achei que foi bem importante porque as vezes a gente acha que ta fazendo alguma coisa certa e ai ouve um opinião de outros grupos...teve um experimento que a gente realizou que foi dica de outro grupo... eu também acabei passando material por mail pro pessoal...Se não fosse a supervisão, não teria essa troca. 


\section{3 - ESTAGIÁRIO L}

Pesq: Bom, fala para mim seu nome inteiro, idade e experiência como professor.

L: L..., 21 anos, tenho experiência como professor particular, mas só de dois alunos... e os estágios de todas as disciplinas.

Pesq: A escola que você estagiou era pública ou particular?

L: Pública.

Pesq: Você considera ela tradicional ou alternativa?

L: Tradicional.

Pesq: Como foi a recepção dos professores, direção, coordenação...

L: A parte da coordenação e professor foi tranqüila, só que ele não deu apoio durante o estágio, mas, no inicio, ele foi bem receptivo.

Pesq: Tá...O que você acha que o estágio contribuiu para sua formação?

L: Para mim esse foi o estágio que mais mexeu comigo, foi mais desafiador, porque foi o primeiro que eu tive a responsabilidade de fechar as notas dos alunos e...como a gente não teve ajuda da escola, a gente teve que se virar com a ajuda de vocês (supervisão)...teve que correr atrás, foi pelo desafio... e também pelo desafio de que até hoje eu não tinha pego uma turma-problema... Foi a primeira turma que realmente deu trabalho para mim... principalmente pela indisciplina... foi bem difícil.

Pesq: Qual era o objetivo inicialmente previsto no plano de estágio?

L: Era fazer...medir a avaliação para ver quais métodos eram mais eficazes para verificar se o aluno aprendeu ou não, aí a gente viu que conforme a gente passava as atividades, a gente percebeu que não chegava no nível de informação adequado para a gente avaliar... a gente acabou verificando qual método o aluno ficava mais a vontade para trabalhar.

Pesq: Quais conteúdos vocês trabalharam? 
L: A gente fez astronomia...as fases da Lua, Estações do ano, um jogo sobre o sistema solar...

Pesq: Por que vocês escolheram este conteúdo?

L: A gente ficou pensando o que seria interessante para os alunos...Astronomia é um bom tema para começar...meu professor de conceitos de astronomia do IAG já falava isso... tinha bastante coisa que saia na TV, Jornal, do dia a dia dos alunos...

Pesq: E tem alguma particularidade para o aluno?

L: Eu acho que não, porque não trabalhamos nada em quantitativo, o que ajudou um pouco era os alunos que sabiam os nomes dos planetas.

Pesq: que estratégias vocês utilizaram para abordar o conteúdo?

L: Inicialmente, a gente usou os alunos para trazer exemplos, levamos material que representava o Sol, a Lua, a Terra e os alunos como exemplo destes corpos. Depois levar um jogo de super trunfo sobre o sistema solar, depois textos científicos sobre a vida extraterrestre, dividindo a sala em grupo para um júri simulado e por fim, um cartaz com a síntese das ideias.

Pesq: A ideia de abordar o conteúdo desta forma veio de algum lugar?

L: Foi até engraçado, porque a gente não discutiu o começo...Astronomia foi um consenso do grupo, mas ... as fases da Lua, quando eu vi na aula de conceitos de astronomia, o professor tinha feito coisas do tipo, acabou vindo daí...

Pesq: E as informações para o seu projeto?

L: O principal foi o texto que a gente viu no curso, mas em astronomia, tem um site com diversas experiências em Física, acabamos encontrando algumas coisas.

Pesq: E o ambiente na escola?

L: No começo a gente não tinha a ideia de que o professor era tão tradicional... a nossa $1^{\mathrm{a}}$ aula foi mais geral - para uma escola pública, mas sem saber contexto. Conforme foi passando, foi um sistema de auto-correção de uma turma para outra...dava errado em uma, já aplicava diferente na outra, logo em seguida. Mas tinha muita indisciplina, muito desrespeitoso, várias vezes tinha aluno pulando muro, sendo presos pela polícia. 
Pesq: E a reação dos alunos?

$\mathrm{L}: \mathrm{Na} 1^{\mathrm{a}}$ e $2^{\mathrm{a}}$ aula eles sentiram que ia ser bem diferente...tudo eles queriam saber de nota, tudo na base da nota... O professor chantageava o aluno com a nota.

Pesq: E durante a aplicação do estágio...aconteceu algum imprevisto que te obrigou a alterar o rumo inicial?

L: O tempo da $1^{a}$ aula...a gente começou a questionar muito os alunos e não deu tempo para acabar.

Pesq: Se tivesse que aplicar de novo o projeto? O que seria mudado?

L: Eu tentaria começar com uma visita ao planetário...mas a escola mudava muito de horário.

Pesq: Se você fosse comentar essa experiência com outro professor...o que você diria?

L: Eu diria da dificuldade do plano de aula, antes da aula...pensar no que pode dar errado... Até então, todo plano de aula que eu tinha feito era a aula, mas não tinha dificuldade... quando você planejar a aula, pensa em tudo que pode dar errado.

Pesq: E se tivesse que mudar na hora?

L: Geralmente essas atividades vem de disciplinas anteriores, que eu lembro de algum exemplo que o professor deu...Eu tinha um professor que deu uma lista de exercícios para outra aula, mas aí ninguém fez...ele teve que dar uma aula expositiva, revisão. No estágio não aconteceu tanto...

Pesq: Você conversou com alguém sobre o estágio?

L: Não...

Pesq: O que você julga importante um professor de Física saber para ensinar?

L: Saber o conteúdo, respeitar o contexto daquela escola...não adianta chegar com uma aula preparada para colégio de elite em escola de periferia, porque não vai dar certo, considerar os conceitos prévios dos alunos, usar exemplos que envolvam estes conhecimentos, fazer aulas que não fiquem no tradicional, dar importância para o aluno.

Pesq: E quanto à supervisão? 
L: Prática, às vezes tinha que discutir com a turma toda...Mas a supervisão contribuiu, ainda mais neste estágio que a gente não tinha apoio do professor...ele não tinha tanto interesse, era bom para desabafar e ter a opinião de alguém que sabe mais do que a gente. 


\section{4 - ESTAGIÁRIO A}

Pesq: Se você quiser falar seu nome, sua idade...

A: A... 21 anos.

Pesq: E... qual é sua experiência docente?

A: Só da faculdade mesmo, do estágio.

Pesq: Como era a escola que você estagiou?

A: Em que sentido?

Pesq: Se ela era pública, particular...

A: Assim... eu percebi que eles não dedicavam nada para os alunos...

Pesq: Os professores?

A: É... eu percebia, na sala dos professores que eles ficavam conversando sobre o café, a vaquinha que eles iam fazer...e a gente ficou muito tempo lá... mesmo a coordenação... a gente perguntava dela por causa das fichas, mas eles sempre falavam que não sabiam se ela estava lá, se já foi embora... faltava comunicação entre eles.... muita gente faltava... ficava no pátio... a diretora era mais forte... tentava colocar ordem... gostei dela.

Pesq: E como receberam vocês?

A: Lá foi muito confuso... a coordenação não sabia se a gente ia conseguir fazer o estágio, e aí mandaram falar com o professor de física, tem que ver... aí a professora de Física foi muito grossa com a gente, que ela já tinha muito estagiário, que a metodologia da escola mudou, que a gente não ia mais poder dar aula, se quisesse tinha que vir de sábado...vê com os outros professores... aí a gente foi procurar outro professor que encaixasse no nosso horário... aí a gente achou o [professor de física]. Ele foi super de boa... recebeu a gente muito bem...recebeu bem, mas ... faz o que quiser, desde o primeiro dia... vocês ficam responsáveis pela nota... desde o primeiro dia já estava preocupado com isso.

Pesq: Sobre o seu estágio... você acha que ele contribuiu para sua formação? 
A: Não... contribuiu como exemplo para não seguir... o professor não ajudou em nada, ele só se preocupou com a nota, não se preocupava com o aprendizado dos alunos, acho que ele não era cobrado pela direção... o perfil dele era passar as notas para a direção... a aula dele que a gente assistiu... quando a gente foi avaliar... ele passou as leis [de Newton] erradas para os alunos...

Pesq: Mas e a sua experiência dando aula?

A: Ah... eu achei o estágio muito decepcionante... eu nunca soube se queria ser professora... mas sempre tive medo de não ser uma boa professora...nesse estágio eu me senti um pouco mal, porque eu não conseguia... eu queria ensinar, mas era aquela indisciplina... eu acho que contribuiu, mas eu não sei ainda, muito bem, com o quê.

Pesq: E você pretende ser professora?

A: Então... aí que ta... este estágio me travou um pouco... eu não sei se eu estou preparada... eu não sei. Assim... quando eu dei aula na escola de aplicação, semestre passado, eu adorei, nossa que legal... mas quando eu fui para lá, era muito desgastante... eles não conseguiam aprender, gostavam muito da nossa aula... eles falavam para a gente que se todos os professores fossem como vocês, que acompanhassem nossa aula, nossas atividades, mas eu não sei se eu estou preparada...

Pesq: Qual era o objetivo do seu plano de estágio?

A: A gente estava bem focado na questão da avaliação... a gente estava lendo o texto da Abib para a aula e agente gostou muito, vamos tentar focar nisso. Analisar aula por aula, a participação deles, filmou... no ensino foi meio difícil... astronomia... achei curioso, tinha muita coisa de astronomia no mundo deles, mas a gente queria ver se realmente eles se interessavam.

Pesq: E você acha que conseguiu atingir este objetivo?

A: Sim... a gente tinha uma pergunta inicial, mas a gente percebeu que aquela pergunta não era o que estava pesquisando... a gente viu quais métodos de avaliação contribuem mais para o aluno expor sua ideias.... deu certo... faltou algo... dava para a gente fazer mais vezes, faltou um pouco isso.

Pesq: E o conteúdo... 
A: Foi astronomia...

Pesq: E tinha algum fio condutor nas estratégias?

A: Não era a avaliação... esta era a questão de pesquisa...o que tinha era aula diferente, longe do tradicional. O que a gente vai dar sem a lousa...

Pesq: E de onde veio a ideia de abordar o conteúdo desta forma?

A: Eu acho que veio da metodologia I. A professora falou muito de aulas diferentes... eu nunca tinha visto isso... ninguém nunca tinha me ensinado... acho que na minha cabeça já vem assim... aula tradicional é ruim... não é que seja ruim... em alguns momentos você tem que sistematizar, é importante... mas eu acho que a atividade diferente... foi o que a gente conversou... o que agente vai dar de diferente?

Pesq: E como foi a recepção dos alunos?

A: Difícil... nas primeiras atividades não deu certo... mas tinha uma aula em uma sala, a gente via que não dava certo e já consertava para a outra, Mas foi difícil, eles não estavam acostumados com isso...

Pesq: E teve algum imprevisto que obrigou vocês a mudar o rumo?

A: Eu não me lembro...

Pesq: Você aplicaria este conteúdo de maneira diferente?

A: Não... eu gostei... eu só tomaria cuidado com os erros, mas a gente devia ter testado antes, para ver o tempo...dosando as mudanças com os alunos, acostumar eles...

Pesq: Se você fosse comentar sua experiência com outro professor, o que você diria?

A: Tem muitos detalhes... o plano de aula é fundamental, se você não se prepara, você chega lá e acontecem muitos imprevistos... controlar o tempo, você precisa saber... essa discussão é prioridade? Não? Então continua como antes... ouvir os alunos, saber o nome deles faz toda a diferença... parece especial quando você fala o nome...

Pesq: Ocorreu de eles fazerem perguntas não previstas? 
A: Sim.. na parte das características específicas de cada planeta, das estações;;; eu fui sincera...eu não sei, deixa ver se ele sabe? Mas sempre um do grupo sabia. Mas teve uma vez que ninguém sabia, mas o professor sabia...

Pesq: E se você estivesse sozinha?

A: Eu diria que eu não sei, ma trago na próxima aula. Não sei como os alunos pensam...o professor tem que saber tudo.

Pesq: Como foi a interação entre os membros do grupo?

A: Quem fez muita coisa fui eu e o W. O L não quer ser professor, não vai trabalhar com isso... ia ficar com a namorada... Eu e o $\mathrm{W}$ fomos mais unidos, deu muito certo... a gente entrava em um consenso, mesmo na aula.

Pesq: Você conversou alguma coisa do seu projeto com alguém de fora?

A: Sim... minha mãe, que é da Educação, contei da pesquisa, da Astronomia, foi bom... parecia que ela era aluna... e ela dizia... se acontecer isso na próxima aula, tenta fazer isso...

Pesq: O que você julga importante um professor de Física saber?

A: Ah...tem que ter paciência, saber ouvir, saber falar com os alunos e... em relação ao conteúdo... tem que saber o conteúdo, mas se não sabe, pesquisa...isso é fundamental.

Pesq: E você já tinha participado alguma experiência com supervisão?

A: Não... eu acho que foi muito relato, que a gente já fazia no estágio. 


\section{5 - ESTAGIÁRIO W}

Pesq: Eu gostaria que você falasse seu nome, idade...

W; W..., 21 anos.

Pesq: E qual é a sua experiência docente?

W: Sem ser no estágio, nenhuma.

Pesq: Como era a escola que você estagiou?

W: Pública...

Pesq: E as relações entre as pessoas?

W: A gente foi lá... primeiro uma professora disse que não ia poder receber a gente, que tinha muitos estagiários, aí o [professor de física] pode receber a gente. A coordenadora pedagógica pareceu... nunca ia.

Pesq: Fala um pouco sobre o seu estágio... você acha que ele contribuiu?

W: Em partes... teve muitas partes negativas... as atividades... os alunos não se engajavam nas atividades... aí a gente não conseguiu avaliar direito se era erro da gente. A gente descobriu que é bom preparar a aula...

Pesq: E se acontecer deles fazerem alguma pergunta que você não saiba responder?

W: Nesse estágio não aconteceu.

Pesq: Qual era o plano inicial do seu estágio?

W: Era avaliar a aprendizagem dos alunos... ver quais maneiras diferentes de avaliar os alunos... só que a gente viu que não estava sendo isso... seriam as melhores formas de avaliar a forma de se expressar dos alunos.

Pesq: E você considera que atingiu este objetivo?

W: Ah... a atividade que a gente fez de jogo foi muito legal, nas outras a gente não conseguiu ver muita coisa, foi meio decepcionante.

Pesq: Que conteúdo vocês optaram... 
W: Astronomia. A gente achou que tinha haver com os alunos. Eu já tinha ideia de falar sobre extraterrestre, não tem uma sequencia lógica.

Pesq: E como eram as atividades?

W: A ideia era que eles argumentassem e a gente tivesse alguma coisa para avaliar. De início a gente só tinha... nenhuma atividade... fomos elaborando.

Pesq: E de onde veio isso?

W: Os alunos da escola eram muito tradicionalistas, só tinha fórmula na lousa...essas atividades trazem eles mais próximos da gente.

Pesq: E como foi a reação dos alunos?

W: Eles estavam muito presos à nota, só se valesse nota. No começo a gente já falou para eles se soltarem mais, que a gente ia olhar participação, não ficar só naquelas atividades.

Pesq: E onde vocês buscaram este conteúdo?

W: Internet, um professor da gente sobre Conceitos de Astronomia e fomos criando...o jogo já existia, a gente só pensou em usar a atividade lúdica para ensinar alguma coisa.

Pesq: Algum texto para ajudar?

W: Sim... nas fases da Lua, a gente teve que estudar...outros textos para a atividade do júri, a parte de questões abertas que a professora já tinha dado.

Pesq: Teve algum imprevisto?

W: Teve a questão do planetário... a gente tinha planejado uma visita, mas a gente viu que não ia dar tempo. Ia ter experimentos no laboratório, mas não deu certo porque tinha pouca aula.

Pesq: Mas, e durante as aulas?

W: Nas fases da Lua, não deu certo, porque a gente foi trocando as pessoas, demorou muito... aí a gente já mudou para a outra sala. No júri simulado a gente viu que dando o texto para ler demorou muito; na outra sala a gente deu uma aula inteira para ler e outra para fazer o júri. 
Pesq: E você faria algo diferente?

W: Para essas turmas, eu não daria essas atividades. Na escola de aplicação eu daria... os alunos gostariam.

Pesq: Se você fosse comentar sua experiência com outro professor... o que você diria?

W: Nas primeiras aulas, o professor não pode exigir muito dos alunos... ir mais devagar, depois vai aumentando.

Pesq: Como foi sua interação com os outros membros do grupo?

W: Então... com a A deu certo. A gente se reunia e tal, fazia relatos, assistia o vídeo.

Com o L, não. Ele vinha nas aulas, mas não vinha nas reuniões. A gente organizou todo o portfólio de estágio, não se dedicou nenhum pouco.

Pesq: Você conversou com alguém sobre o estágio?

W: Não, só com o L e a A.

Pesq: O que você acha importante um professor de Física saber?

W: Tem que escutar os alunos, estar sempre ligado nas notícias, sempre buscando fontes, artigos novos sobre o ensino, atividades de experimentação para levar para sala...

Pesq: Você já tinha participado de alguma experiência com a supervisão?

W: Já, acho positivo, dá para a gente discutir o que não está dando certo. O professor olhando de fora é melhor... 
ANEXO 1 - ALGUNS ELEMENTOS DOS PORTFÓLIOS DOS ESTAGIÁRIOS

\section{GRUPO I}

\section{Projeto de Estágio}

\section{A Física da Propulsão}

Estagiários:

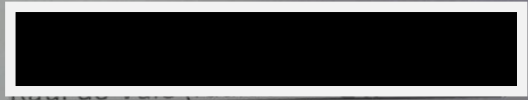

Professora: Fátima

Escola: E. E. Almeida Junior

Capa do projeto de estágio apresentado pelo grupo I. 
Escola: E. E. Almeida Jr. (Av. Eng. Heitor A. Eiras Garcia, 1874)

Professora Colaboradora: Fátima

Séries e Classes: 1ㅇ e 2 EM

Horário: Segunda-Feira das 7:00 às 10:30 e quarta-feira das 7:00 as 10:30.

Aspectos Gerais do Projeto:

Esse projeto tentará trabalhar os conceitos de conservação de momento com a motivação de que os alunos aprenderão a construir um foguete movido à água. Durante as aulas os conceitos serão trabalhados pouco a pouco, usando atividades e demonstrações experimentais. Na ultima aula, um foguete será construído pela turma.

Objetivos Gerais:

O objetivo é analisar a eficácia de um elemento motivador (construção de um foguete) durante a apresentação dos conceitos de conservação do momento.

Dimensão de pesquisa:

Questão a ser respondida: Como a construção do foguete no fim do curso motiva os alunos a entenderem conservação do momento?

Logo no começo do curso serão mostrados vídeos de foguetes no espaço e na Terra usando a propulsão para se locomover. Explicaremos aos alunos que na quarta aula, construiremos um foguete de água.

Durante cada aula, o assunto "foguete" será trazido para a aula, afim de que os alunos sempre tenham em mente que o objetivo é eles entenderem como funciona a propulsão do foguete.

Trechos do projeto de estágio do Grupo I - Objetivos Gerais 


\begin{tabular}{|c|c|c|c|c|c|}
\hline Aulas & $\begin{array}{c}\text { Tema } \\
\text { Principal }\end{array}$ & $\begin{array}{c}\text { Atividades do } \\
\text { Professor }\end{array}$ & $\begin{array}{c}\text { Atividades dos } \\
\text { Alunos }\end{array}$ & $\begin{array}{l}\text { Recursos } \\
\text { materiais }\end{array}$ & Avaliaçāo \\
\hline $\begin{array}{l}1 \\
\left(1 / 10 e^{3 / 10)}\right.\end{array}$ & $\begin{array}{l}\text { Apresentaçāo } \\
\text { foguetes }\end{array}$ & $\begin{array}{l}\text { Mostrar videos sobre } \\
\text { foguetes e } \\
\text { problematizar a } \\
\text { propulsão }\end{array}$ & $\begin{array}{l}\text { Assistir os } \\
\text { videos e discutir } \\
\text { as concepções } \\
\text { sobre propulsão } \\
\end{array}$ & $\begin{array}{l}\text { Computador } \\
\text { ou televisão } \\
\text { com aparelho } \\
\text { de DVD. }\end{array}$ & $\begin{array}{l}\text { Alunos escreverão suas } \\
\text { concepçães sobre } \\
\text { propulsão }\end{array}$ \\
\hline $\begin{array}{l}2 \\
(8 / 10 \text { e 10/10) }\end{array}$ & $\begin{array}{l}\text { Conservaçâo do } \\
\text { momento }\end{array}$ & $\begin{array}{l}\text { Guiar uma } \\
\text { demonstração } \\
\text { experimental: dois } \\
\text { skatistas se } \\
\text { empurram }\end{array}$ & $\begin{array}{l}\text { Discutire } \\
\text { executar a } \\
\text { experiência }\end{array}$ & 2 Skates & $\begin{array}{l}\text { Os alunos responderão } \\
\text { questōes sobre o que } \\
\text { acontece quando } \\
\text { skatistas se empurram, } \\
\text { ou um skatista empurra } \\
\text { o outro, etc. }\end{array}$ \\
\hline $\begin{array}{l}3 \\
(15 / 10 \text { e } 17 / 10)\end{array}$ & $\begin{array}{l}\text { Conservação do } \\
\text { momento }\end{array}$ & $\begin{array}{l}\text { Demonstração } \\
\text { experimental: bexiga } \\
\text { cheia voando ao ser } \\
\text { solta. Discussão } \\
\text { sobre esse } \\
\text { experimento e o da } \\
\text { aula anterior }\end{array}$ & $\begin{array}{l}\text { Discutir sobre o } \\
\text { que eles } \\
\text { observam nessa } \\
\text { experiência e na } \\
\text { da ultima aula. }\end{array}$ & $\begin{array}{l}\text { Bexiga, } \\
\text { barbante, } \\
\text { canudo. }\end{array}$ & $\begin{array}{l}\text { Alunos escreverão } \\
\text { respostas sobre a } \\
\text { questăo: o que faz a } \\
\text { bexiga se mover quando } \\
\text { ela é solta? }\end{array}$ \\
\hline $\begin{array}{l}4 \\
(22 / 10 \text { e } 24 / 10)\end{array}$ & $\begin{array}{l}\text { Construção do } \\
\text { foguete }\end{array}$ & $\begin{array}{l}\text { Guiar a construção } \\
\text { do foguete em sala } \\
\text { de aula }\end{array}$ & $\begin{array}{l}\text { Ajudar na } \\
\text { construção do } \\
\text { foguete }\end{array}$ & $\begin{array}{l}\text { Materiais para } \\
\text { a construção } \\
\text { do foguete }\end{array}$ & $\begin{array}{l}\text { Alunos escreveräo } \\
\text { respostas sobre a } \\
\text { questão: por que o } \\
\text { foguete sobe? }\end{array}$ \\
\hline
\end{tabular}

Mais detalhes sobre as aulas:

Aula 1:

Durante a primeira aula, será mostrado aos alunos uma compilação de vídeos que mostram foguetes na Terra e no espaço usando a propusão.

Ao término do vídeo, os alunos serão questionados sobre o que faz o foguete se movimentar, como funciona a propulsão?

A ideia é conhecer as concepções dos alunos sobre a propulsão e problematizar esse conceito aos alunos. Ou seja, na medida em que os alunos apresentam suas concepções, nós os questionamos sobre o limite da validade de suas hipóteses. Na medida em que colocamos essas questões aos alunos, esperamos que eles se interessem mais por essa pergunta: "como funciona a propulsão?".

Em seguida, será explicado aos alunos que em 3 aula construiremos um foguete movido à água. Mas para construir o foguete é necessário entender como ele se move.

No fim da aula, será pedido aos alunos que eles escrevam sobre como eles acham que funciona a propulsão. Dessa maneira ficarão registradas as concepções dos alunos sobre o tema.

Aula 2:

Skatistas se empurram:

Para essa experiência é necessário que sejam levados dois skates e que a aula seja realizada na quadra da escola. Lá, dois alunos serão escolhidos para ficarem, cada um, em cima

Cronograma e Detalhamento das aulas 1 e 2 -Projeto de Estágio do Grupo I 
de um skate. Todos a postos, será perguntado aos alunos o que acontecerá se o skatista 1 empurrar o skatista 2. O S1 fica parado? O S2 fica parado? Algum deles se movimentará? Dai eles se empurram e é discutido o que foi visto.

Em seguida é pedido que ambos se empurrem. E agora? O que acontecerá? Essas questōes devem ser colocadas aos alunos antes e depois da experiência.

Depois dessas duas discussões, é colocada a questão aos alunos: num foguete, tem alguma coisa empurrando outra coisa?

Em seguida, pedimos aos alunos que respondam um questionário com as seguintes questōes:

O que acontece se dois skatistas estão parados e um skatista empurra o outro?

- O que acontece se dois skatistas estão parados e os dois se empurram?

Aula 3:

Experiência da bexiga:

É necessário que seja levado para a sala de aula uma bexiga, um canudo, fita crepe, pequenas esferas metálicas, e um barbante.

Primeiramente a bexiga será cheia de ar e solta. Os alunos deverão responder porque eles acham que a bexiga sai voando. $O$ que está empurrando a bexiga?

Em seguida, a bexiga cheia, deve ser colada com a fita crepe no canudo, por onde passa um barbante como mostrado na figura.

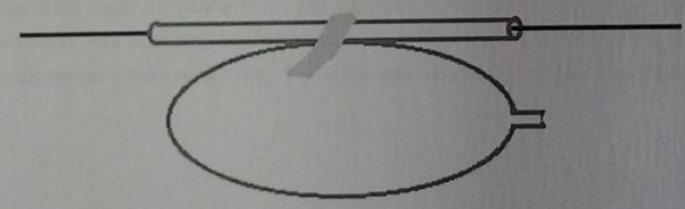

Agora será discutido o que acontece se colocamos mais massa na bexiga. Isso será feito colocando as pequenas esferas metálicas dentro da bexiga cheia e soltando-a. Será feita a medida de quanto a bexiga anda cada vez que são adicionadas mais esferas.

Em seguida será discutido com os alunos como a bexiga se move. De onde vem essa força? Ela está jogando alguma coisa para fora? O que? O que isso tem a ver com a experiência dos skatistas? O foguete também faz a mesma coisa? É assim que o foguete se move?

No fim da aula, os alunos escreverão uma resposta para a seguinte pergunta:

De onde sai a força que faz a bexiga voar quando a soltamos?

Atividade Experimental da Bexiga (aula 3) - Grupo I 
Aula 4:

Construção do foguete:

Para a construção do foguete utilizaremos

- 2 garrafas descartáveis de refrigerante (PET) de dois litros. Utilize somente PET, pois este material pode suportar altissimas pressöes internas;

- placa pluma ou isopor de alta densidade (facilmente encontrada em supermercados na forma de bandejas para embalagem de alimentos);

- fita adesiva transparente;

- 1 rolha de cortiça grande;

-1 válvula de pneu de bicicleta

1 tubo de caneta vazio

-1 mangueira com até $6 \mathrm{~mm}$ de diâmetro

- 1 bomba de encher pneu de bicicleta

As duas garrafas PET são os principais componentes do foguete já que serão utilizadas para a construção da fuselagem, que é composta pela câmara de combustão (no nosso caso chamaremos de câmara de compressão) e pelo nariz, região frontal do foguete.

Para a câmara de compressão utilizaremos uma garrafa PET inteira sem alterações. Esta é a parte do foguete em que estará contido o seu combustivel (a água). Para o nariz, utilizaremos apenas a parte de cima da garrafa, cônica, como mostra a Fig. 1a.

Essa peça tem a função de minimizar o atrito do ar durante o vôo do foguete e fornecer um formato mais aerodinâmico. Em seguida, fixe a parte cônica no fundo da outra garrafa inteira com a fita adesiva, conforme mostra a Fig. 1b. É importante que se tenha um bom alinhamento entre estas partes (Fig. 1c), para que não haja maiores complicações durante o vôo. 


\section{Observacões feitas durante o estionio}

Observações iniciais:

A professora Fátima é originalmente professora de matemática tem suas referências numa pedagogia mais tradicional. Ela já é aposentada, mas continua trabalhando como professora estadual para complementar sua renda.

Para ela, é importante escrever a matéria da aula na lousa e fazer os alunos copiarem. Um aluno que não faz barulho, piadas e que copia a matéria é um bom aluno.

Das poucas obervações que fiz, vi que ela tem duas maneiras caracteristicas de dar uma aula. Uma é preparando a aula baseada no caderno do estado, onde os alunos discutem sobre um assunto em que eles tenham alguma experiència. como por exemplo, astronomia. A aula gira em torno da discussão sobre os conhecimentos previos dos alunos. Na medida em que a professora pode, ela introduz alguma informação nova. $A$ outra maneira de dar aula é apresentando um conjunto de fórmulas que descrevem um fenómeno físico na lousa e propondo um problema fechado para os alunos resolverem. Esses exercicios são entregues para a professora no fím da aula e usados para avaliação.

A professora tem uma empatia e firmeza na sua relação com os alunos. Ela consegue manter a sala de aula atenta às suas explicações. Quando alguém começa a atrapalhar, ela logo toma o controle. Isso foi muito útil durante todo o estágio

Ela nos recomendou que não utilizássemos muito a matemática durante as aulas do estágio, afinal, os alunos perdem o interesse na discussão. Para ela, é melhor fazer uma aula de lisica onde se discute os fenômenos qualitativamente.

Ia aula:

O objetivo principal da aula é problematizar a propulsão. Os alunos assitem a um video de foguetes sendo lançados e em seguida discute-se o que foi visto.

A turma presta atenção aos videos. Durante a discussão, vê-se que os alunos se empenham a participar respondendo nossas perguntas como: "porque o foguete chinês tem um formato e o americano tem outro?". "o que é igual em todos os foguetes?". etc.

Eles fazem a associação de que a quantidade de fumaça gerada no lançamento tem uma relação com a potência da propulsão. Quanto mais fumaça, mais potente é o foguete

$2^{a}$ aula:

Essa é a aula com a atividade experimental dos skates. Alunos de diferentes massas, e tamanhos, são colocados em cima de um skate c outros os empurram. Analisa-se aqui a relação entre a velocidade dos alunos empurrados com a sua massa.

A atividade tinha sido planejada para acontecer no pátio ou na quadra da escola, mas observou-se que era possivel e muito mais organizado se ela fosse leita dentro da própria sala de aula.

Uma breve explicação é feita antes da atividade começar. Nesse momento é um pouco mais dificil manter os alunos interessados. Quando chamamos alguns pra participar da atividade. eles ficam mais interessados.

A atividade e discussão da atividade foi rapida demais. Os alunos ficaram uns $10 \mathrm{~min}$ apenas esperando o sinal tocar.

Observou-se que alguns alunos acham a atividade boba, com os resultados óbvios demais. Parece ser muito claro pros alunos que quando se aumenta a massa, diminui a velocidade.

O objetivo da aula é começar a falar sobre a conservação da quantidade de movimento, mas não ficou muito claro que os alunos entenderam essa relação. Parece que as suas concepçỏes já eram boas o suliciente para descrever aquele fenómeno, sem a necessidade do conhecimento físico.

Sentimos que a atividade do skate nào rendeu uma discussão fértil, e que poderia ser repensada numa futura aplicaçâo dessa sequência de aulas.

\section{Relatos do Estágio - Grupo I}


3aula:

Essa aula da continuidade à introducto da conservacio da quantidade de movimento. 1 feita uma atividade experimental com uma bexiga, presa a um canudo, por onde passa um barbante. A bexiga é cheia e solta pra se movimentar ao longo do barbante. Essa experiència é feita varias vezes com pesos e sem pesos.

Da mesma maneira que na $2^{*}$ aula, os alunos não ficam muito interessados na primeira parte da aula, onde apresentamos alguns conceitos como o da quantidade de movimento. Eles começam a se interessar mais quando os chamamos para a montagem do aparato experimental.

E importante observar que nós acreditamos que a participação dos alunos na montagem e execução dos experimentos ajuda na motivação dos alunos com relação à aula. Tanto na $2^{2}$ quanto na $3^{3}$ aula, os alunos participaram ativamente da montagem e execução dos experimentos.

A discussão foi bem mais participativa que na $2^{a}$ aula. Mas mesmo assim, ficou um sentimento de que os conceitos de conservacào da quantidade de movimento não foram bem assimilados.

\section{4? aula:}

Nessa aula. o foguete foi construido pelos alunos para ser lançado na próxima. A sala é dividida em 4 ou 5 grupos e cada grupo constrói um foguete com o material que levamos e seguindo nossas instruções.

Os alunos ficaram bastante ocupados e interessados em todo o processo da montagem.

Houve um episódio em uma turma em que a professora ficou indignada com alguns alunos que estavam fazendo piadas e os mandou para conversar com a coordenadora. Fora isso, as aulas ocorreram tudo bem.

\section{$\underline{5^{3} \text { aula: }}$}

Essa é a ultima aula em que o foguete é lançado. Os alunos são levados até a quadra, a estrutura do foguete é armada e um dos alunos bombeia o foguete até ele começar a subir.

Os alunos estavam sempre muito atentos. Todos muito curiosos com o que iria acontecer Até mesmo alunos de outras turmas e professores que as vezes passavam perto da quadra paravan pra ver e perguntar.

A aula foi principalmente a execução do lançamento do foguete, faltando uma discussão mais detalhada sobre o funcionamento da propulsão dos foguetes em geral. $\dot{E}$ claro que eles entenderam como o foguete que nós montamos funciona, mas faltou uma discussão sobre : propulsão dos foguetes que foram mostrados nos videos. Os alunos ainda acham que o que o foguete lança é fogo.

\section{Relatos do Estágio - Grupo I}




\section{GRUPO II}

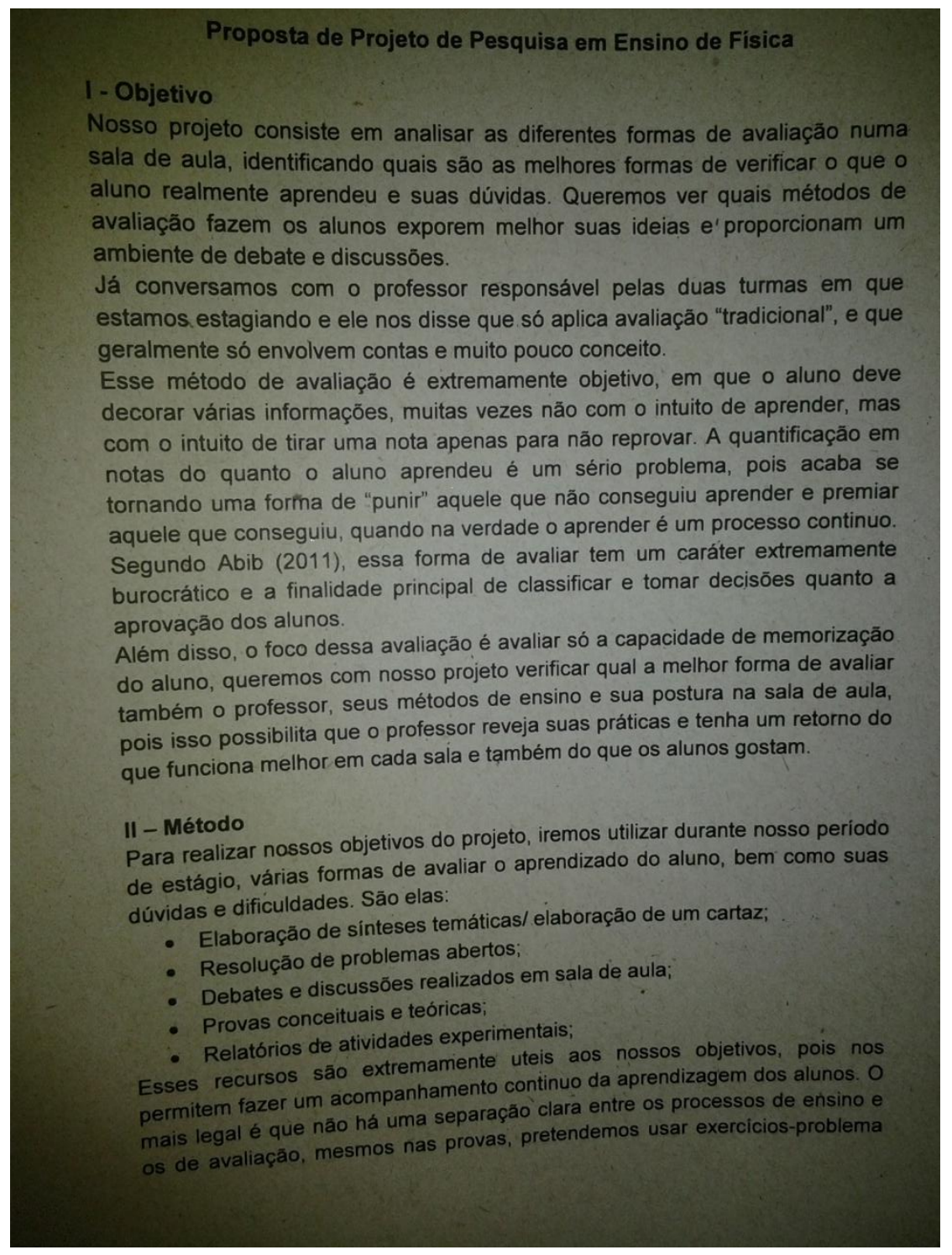

Projeto de Estágio do Grupo II - Objetivos Gerais 


\section{$02 / 11$ - Feriado}

09/11 - Aula 07

- Tema: Brincando de Astronomia (jogo)

- Atividades do professor: dividir a sala

regras do jogo para os a em pequenos grupos, explicar as o jogo.

- Atividades dos alunos: se reunirem em grupo e participar de debates dentro do grupo, a fim de responderem as questōes.

- Recursos materiais: jogo de cartas relacionado a astronomia, elaborado pelos alunos $(X, Y)$ durante a disciplina Práticas de Ensino, de 2011.

- Avaliação: feita durante a aula e pela visualização dos vídeos, através da participação dos alunos, das respostas dadas pelos grupos e também pediremos que os alunos nos façam um breve relato se gostaram ou não da atividade (afinal é importante avaliar a aula e os recursos utilizados).

12/11 - Aula 08 (Talvez)

- Tema: Visitação ao Planetário do Ibirapuera.

- Atividades do professor: organizar e supervisionar a visitação dos alunos ao planetário do Ibirapuera. Agendar o dia.

- Atividades dos alunos: participar da atividade fora de sala de aula.

- Recursos materiais: precisamos ainda verificar como levar os alunos pra lá, se a escola tem meios disponiveis e se os professores das outras matérias permitirão que eles faltem.

- Avaliação: nessa aula não haverá uma avaliação direta, apenas iremos observar o comportamento dos alunos e suas observaçōes feitas e suas dúvidas.

16/ 11 - Recesso Escolar

23/11 - Aula 09

- Tema: Discussão final com os alunos

- Atividades do professor: nessa última aula (que devido ao tempo, talvez - Atividades dada por nós), pensamos em abrir uma roda de discussōes para discutir como foi a visita, do que eles mais gostaram, o que eles acharam das nossas aulas, tirar eventuais dúvidas que eles ainda tenham e falar quais foram nossos critérios de avaliaçãa.

Atividades dos alunos: irăo participar das discussōes e levantar eventuais

dúvidas.

Recursos materiais: a priori, nenhum

Proposta inicial do cronograma de atividades - Grupo II 
Relato do estágio junto com plano de aula $-2^{\circ}$ aula - Dia 24 de setembro

1. Algumas dificuldades

Apenas iriamos fazer estágio de sexta-feira. Contudo, devido aos feriados, eleição e provas que haverão na escola, percebemos que praticamente não haverá aula de sexta em outubro, então tivemo que pegar algumas aulas, com as mesmas turmas, na segunda-feira. Mas ficamos sabendo disso na última aula que fomos (dia 21) e a próxima aula que já teriamos que dar, seria na próxima segund: (hoje, dia 24). Ou seja, tivemos que programar essa aula em pouquissimo tempo.

Foi muito dificil prepararmos essa aula e demoramos bastante para decidirmos quais temas iriamos trabalhar e como, pois essa seria a nossa primeira aula de astronomia com eles. Pensamos em muitas coisas:

- Nada de fórmulas por enquanto, pois parece que se eles veem contas, fórmulas, já travam e nem querem aprender;

- Não queriamos passar apenas conceitos prontos de forma expositiva, queriamos fazer uma aula dinâmica, onde os alunos participassem bastante;

- Queriamos chamar a atenção deles para o assunto, algo que eles achem interessante. Contudo é dificil pensar em qual assunto seria interessante para a maioria e em como trabalhar em 50 minutos;

-Tentamos achar videos de 5 minutos, para começarmos a aula mostrando como o universo é grande, mostrando a proporção dos planetas, as gałáxias, mas nâo sabiamos se havia equipamentos na escola para isso, e também não conseguimos achar nada como gostariamos.

- Pegamos vários livros didáticos (como o Quanta Física e o Física em Contextos) e os cadernos da Proposta Curricular do Estado de São Paulo, para termos ideias de como começar o tema Astronomia, e esses materiais ajudaram bastante.

Decidimos que nosso objetivo seria que os alunos entendessem sobre a Lua, que faz parte do cotidiano de todos e imaginamos que chamaria a atenção, sobre as estações e sobre o contexto histórico, de como "começaram" os estudos de Astronomia.

2. Plano de aula

Começar perguntando o que eles sabem sobre Astronomia, para termos uma noção dos conhecimentos prévios dos alunos e começarmos falando pelo que eles sabem. Nessa parte, já queremos engajar a parte histórica, só para eles terem uma noção de que esses estudos são bem antigos. Depois, falaremos sobre a rotação, translação, movimento do Sol, da Lua, da Terra, tudo isso para explicarmos sobre a Lua, como é o seu movimento, suas fases, porque vemo-la cheia, depois minguante.... o que está acontecendo. Nessa parte, nossa metodologia é trabalhar em equipe. L evaremos um globo (o qual tem um cabo de vassoura no meio, para mostrarmos que está inclinado) nara representar a Terra, uma bolinha para representar o Sol e outra bolinha para representar a Lua. Chamaremos três alunos da sala e cada um representarál segurará um astro. Através dessa representação, vamos conduzindo os alunos a se movimentar, explicando o que está acontecendo. comocoso ponto de referência será o Brasil). Queremos fazer isso através de

\section{Observações sobre o estágio - grupo II}




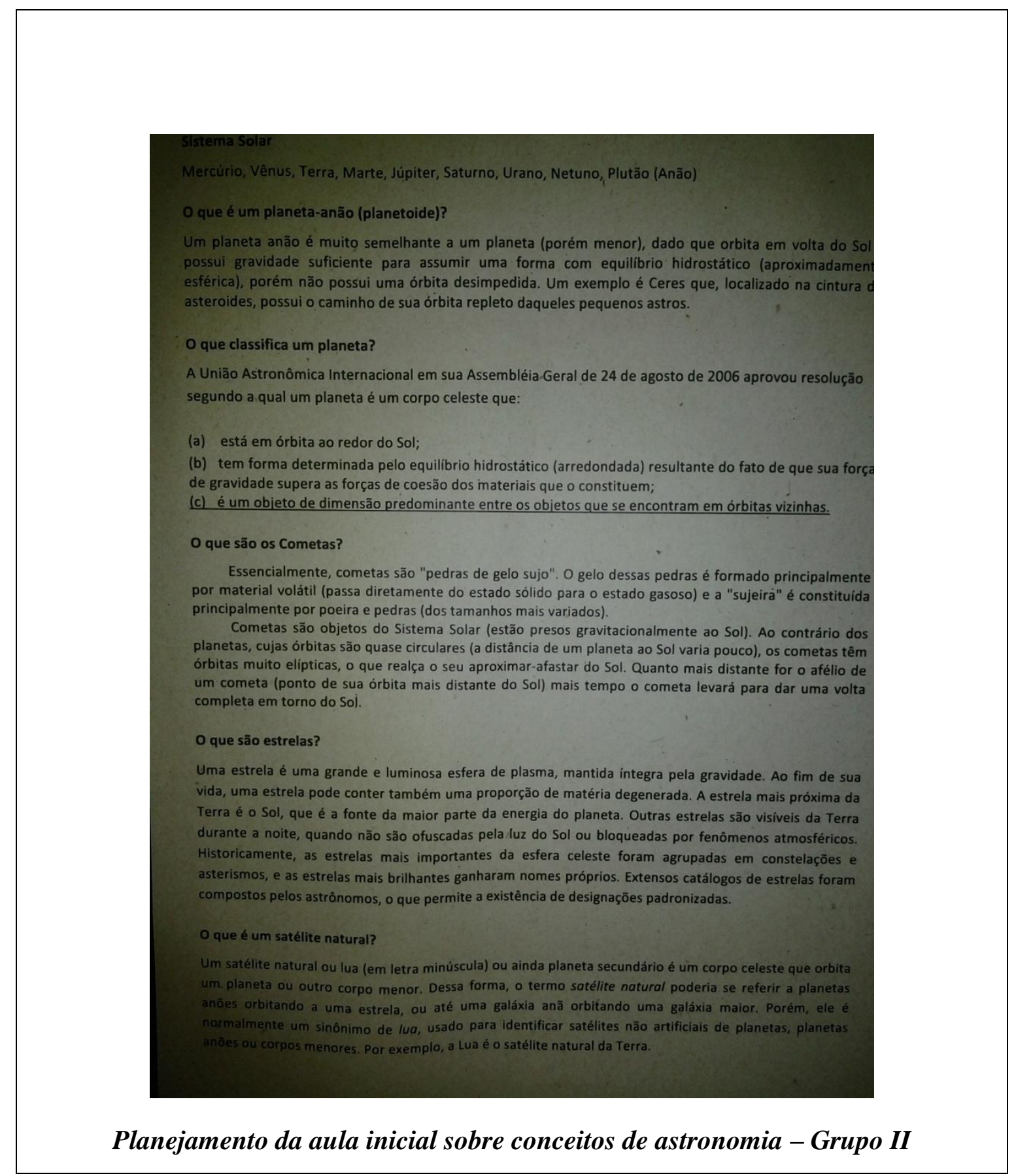




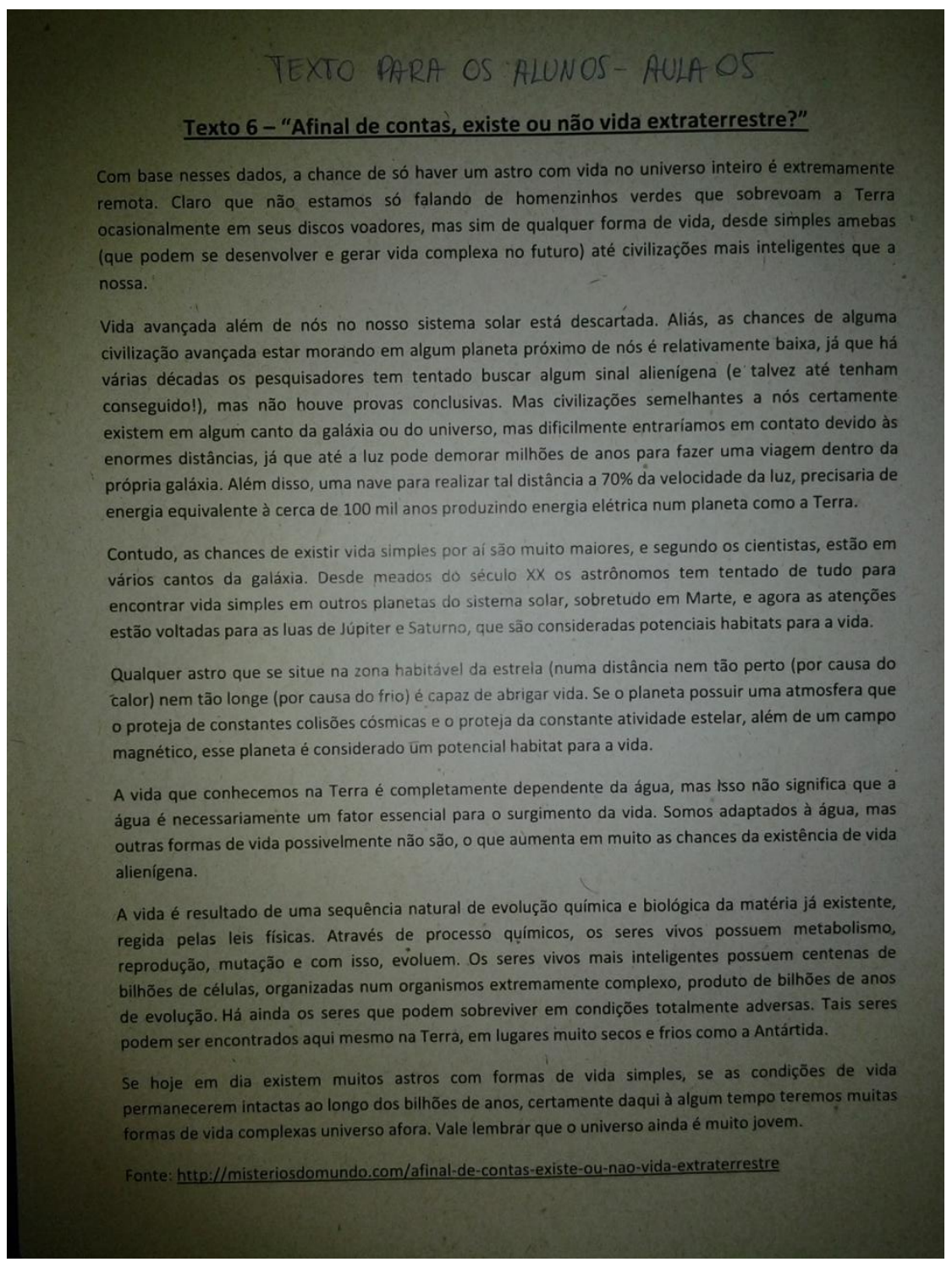

Um dos textos apresentados aos alunos para discutir a existência de vida extraterrestre - Grupo II 